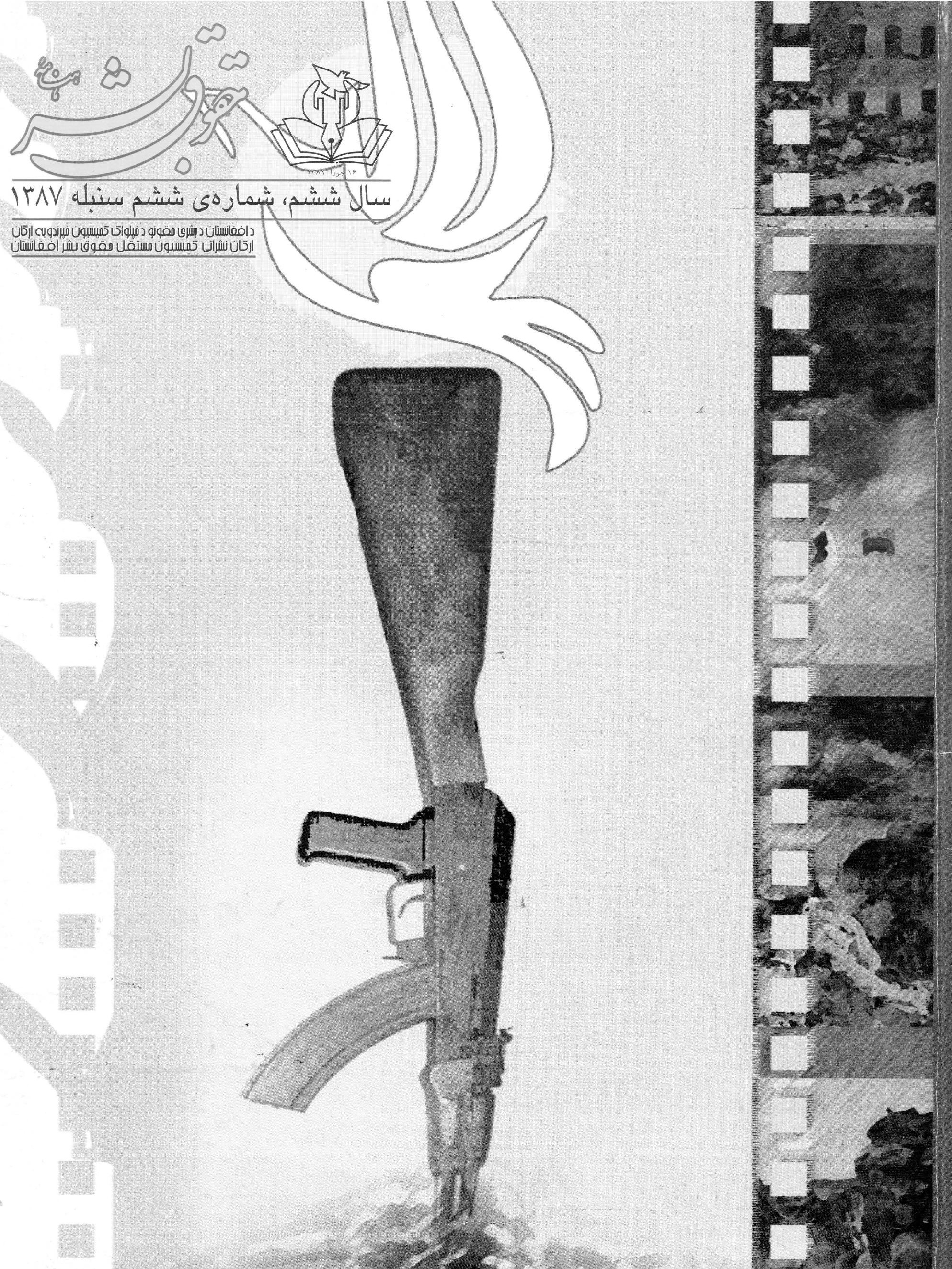





\section{مقوق النقإ}

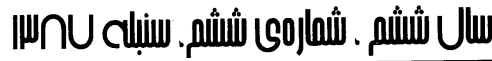

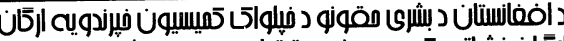

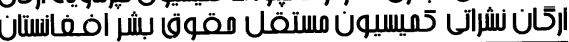

كاهي به تلفات غر نظاميان در افغانستان

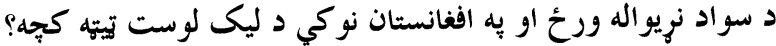
خواهر ان؛ قربانيان ميراث هيولاى وحشت (تجاوز جنسى بر كود كان) 1ه 19 19

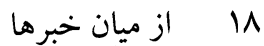

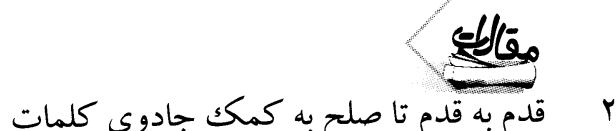

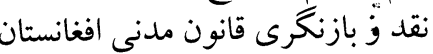
r. YF دتولنيزو شخرو ارزونه او يوخو سياربنتنبي! Y人

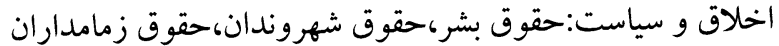
يه نريوالو عمومي حقوقو كي مويدات

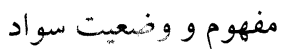

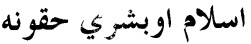
فلسفهى حقوق بشر (كفتار دهم): دستاورددهاى فلسفهى

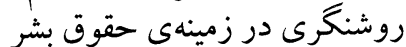

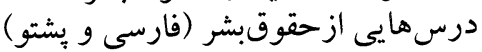

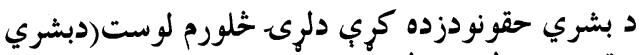

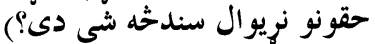

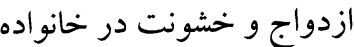

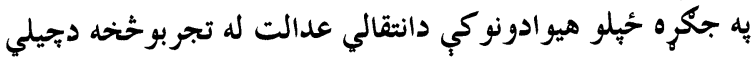

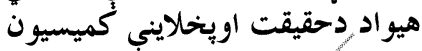
pq
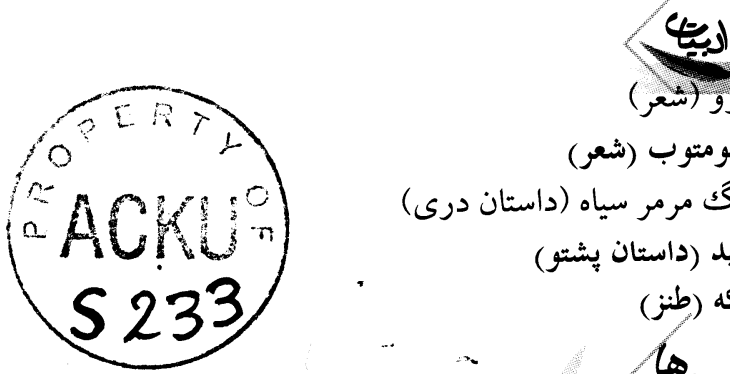

( T) ماشو مترب (شعر)

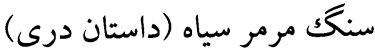
هV

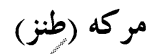
منسونهان sing

$$
\begin{aligned}
& \text { Irai is is } \\
& \text { عبدالشكور اخلاقى مسول } \\
& \text { معاون } \\
& \text { نور آغا مراد } \\
& \text { ويراستار درى } \\
& \text { عبدالشكور نظرى } \\
& \text { ويراستار يشتو } \\
& \text { ن. مراد } \\
& \text { زير نظر شوراى نويسندكان }
\end{aligned}
$$

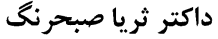

$$
\begin{aligned}
& \text { يوهنيار فهيم حكيم } \\
& \text { محمد فريد حميدى } \\
& \text { مولوى غلام محمد غريب }
\end{aligned}
$$

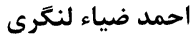

$$
\begin{aligned}
& \text { سلمانعلى ارزكانى إنى } \\
& \text { صفحه آرا } \\
& \text { محمد مظفرى } \\
& \text { توزيع } \\
& \text { بشير احمد ارمند } \\
& \text { طرحهاى جلد } \\
& \text { محمد مظفرى }
\end{aligned}
$$

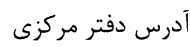

$$
\begin{aligned}
& \text { افغانستان، كابل، كارته سه، يل سرخ } \\
& \text { تلفون } \\
& \text {..9T (.) VAr+19.F. } \\
& \text { فكس }
\end{aligned}
$$

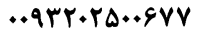

$$
\begin{aligned}
& \text { وب سايت }
\end{aligned}
$$

9. 9 و اعلاميه اسلامى حقوق بشر (قسمت دوم و بايانى)

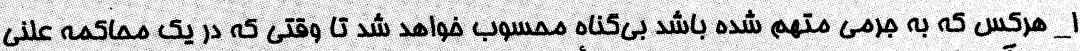
كم در آن كليمى تضمينهاى للام براى دفاع او تأهين شده باشد هرم او قانونا بم اثبات برسد.

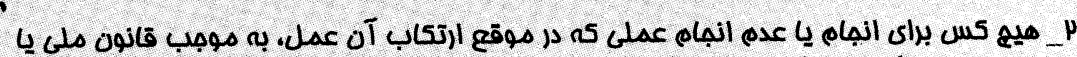

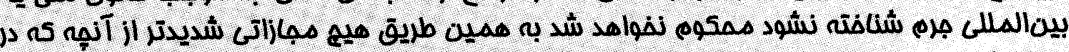
اعلاهيnى بهانى همَوق بشر 


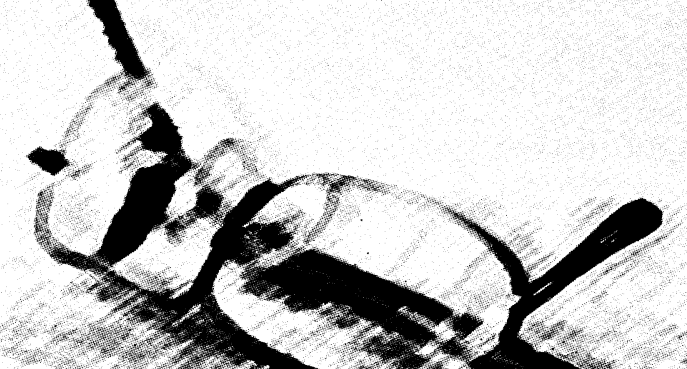

\section{خودسازي، كام اول براى رسيدن به صلح}

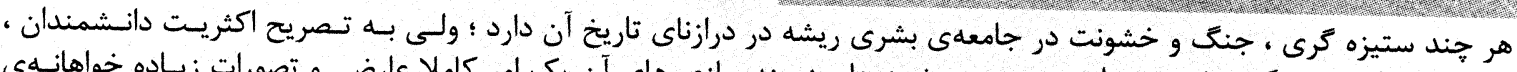

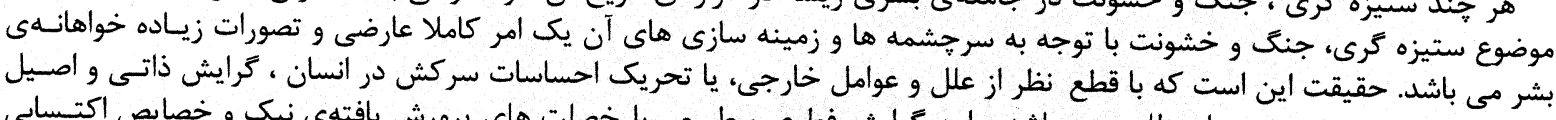

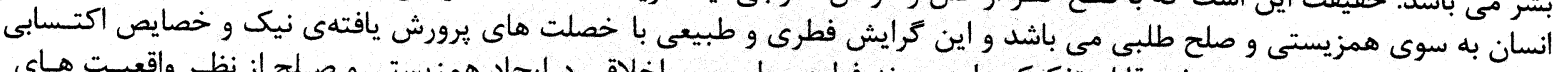

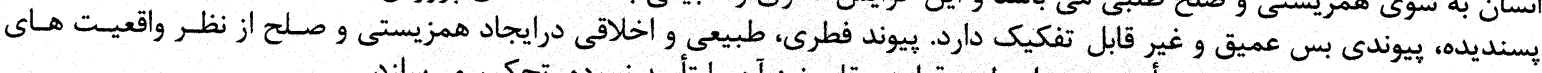

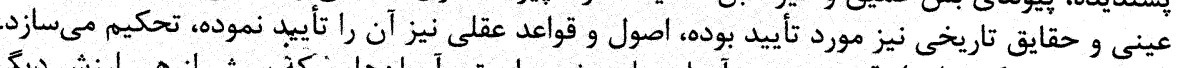

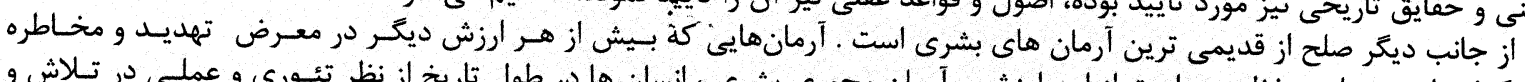

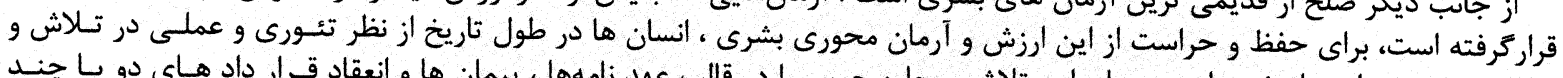

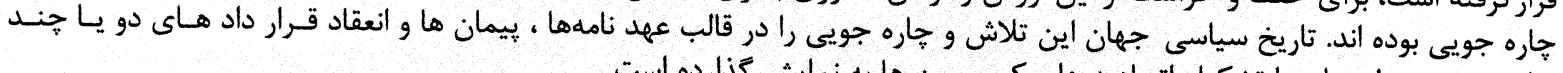

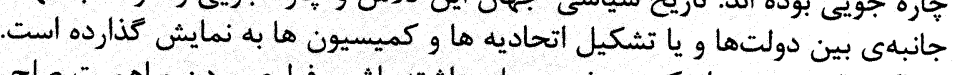

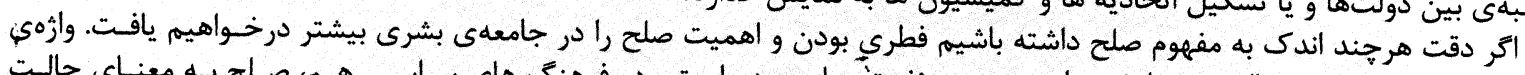

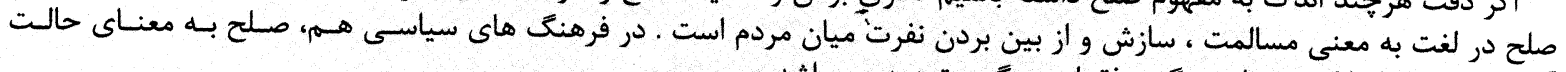

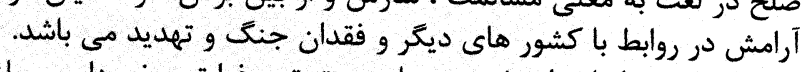

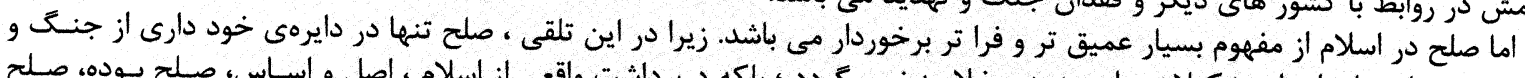

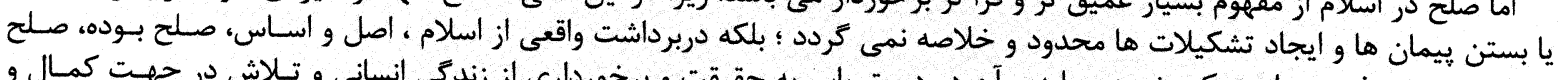

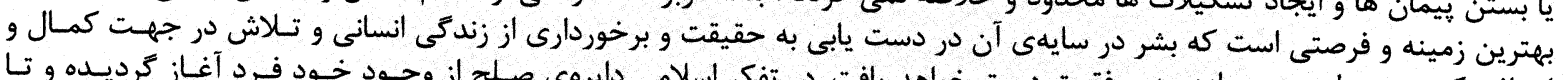

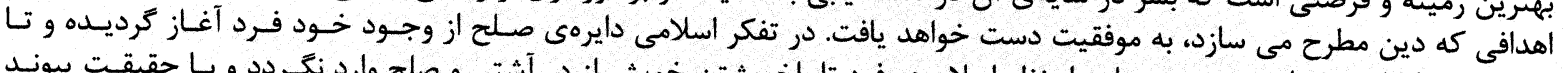

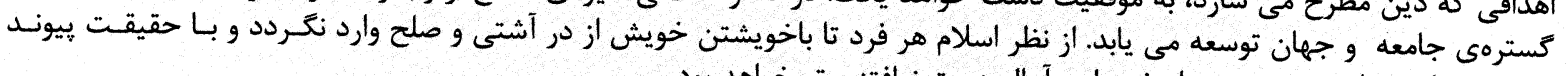

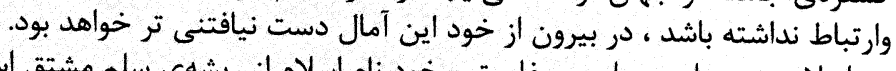

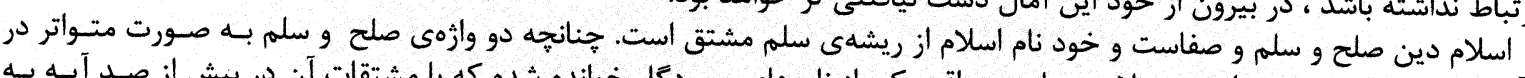

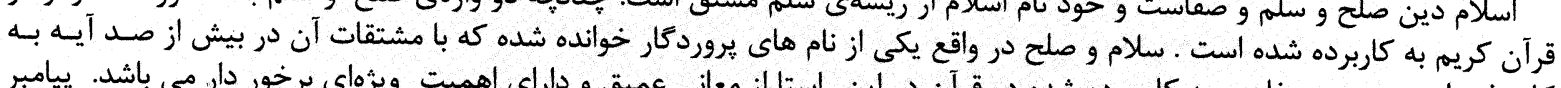

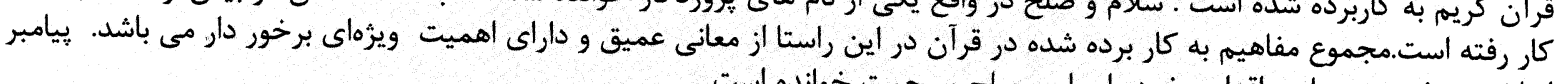

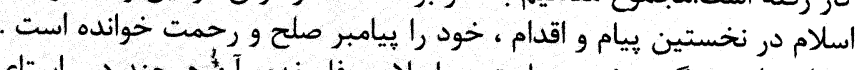

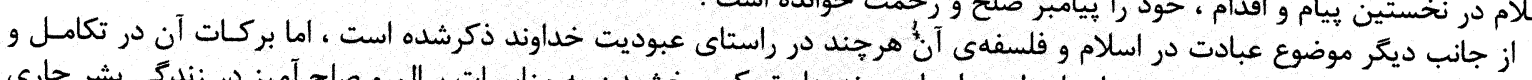

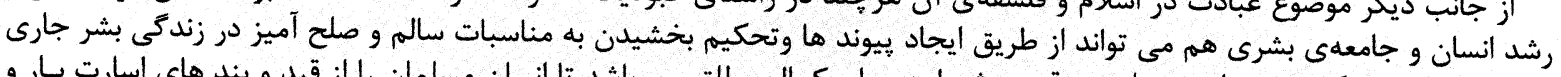

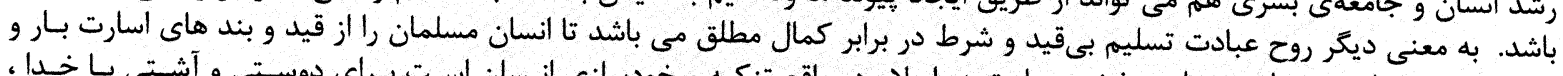

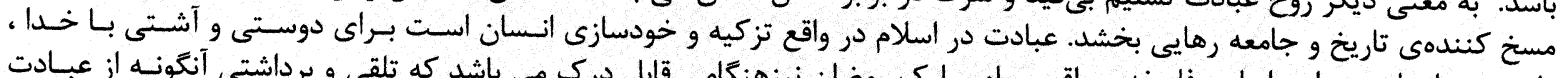

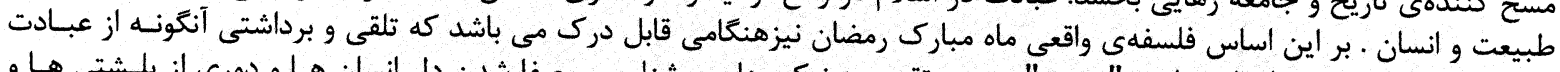

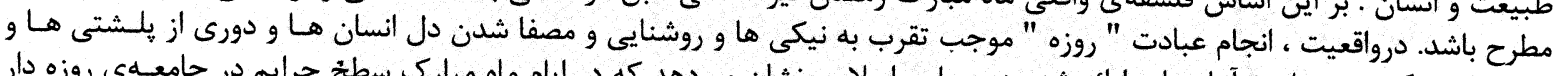

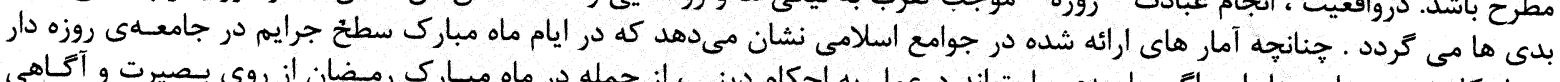

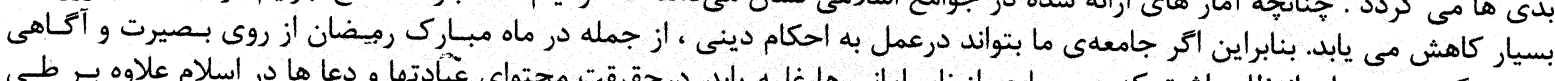

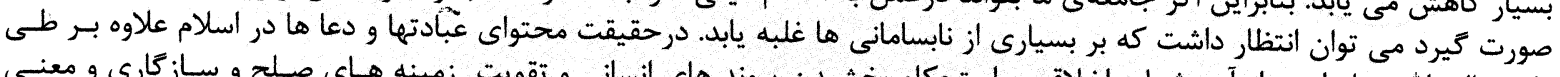

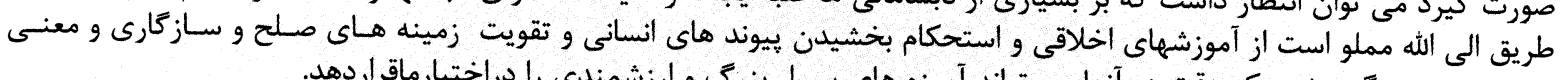

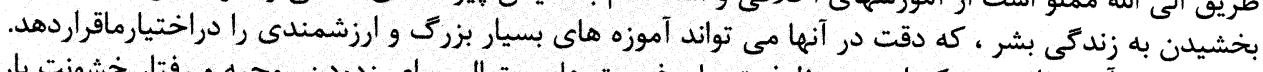

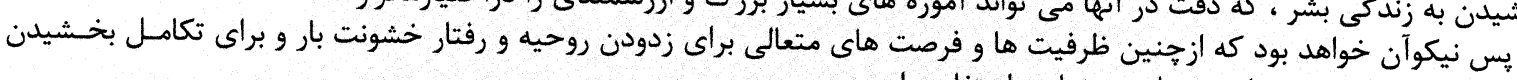

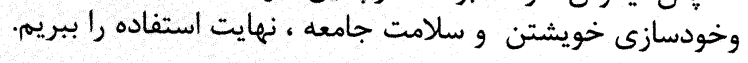




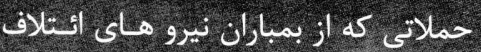

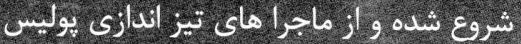

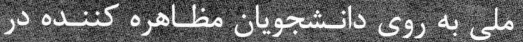

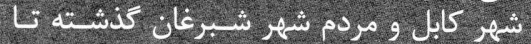
ان ن.

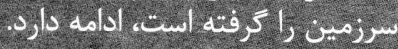
a ela

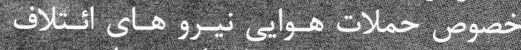

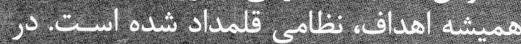

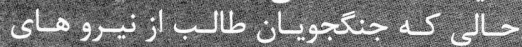

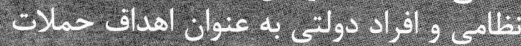

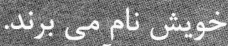

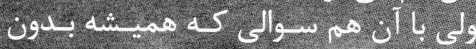

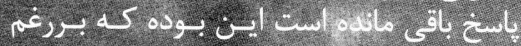
at

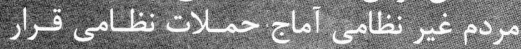

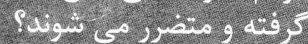

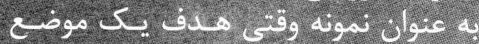
ज.

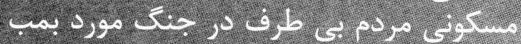

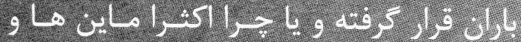

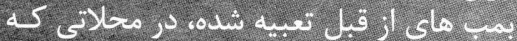

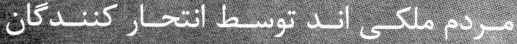

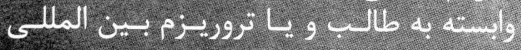

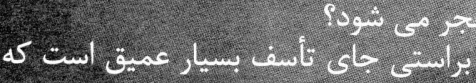

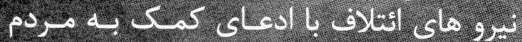

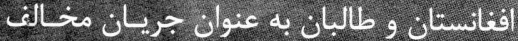

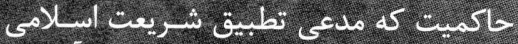

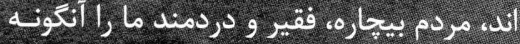
كاك

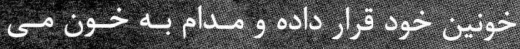

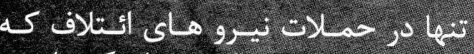

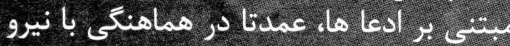

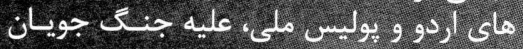

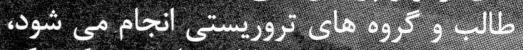

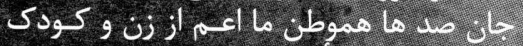

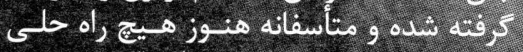
جن

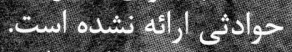

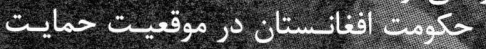

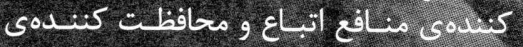

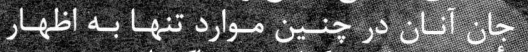

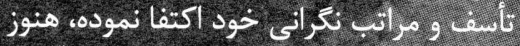
. ثارث

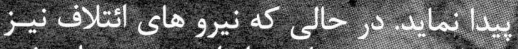
每

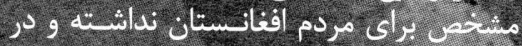
تكوب.

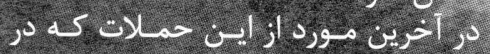

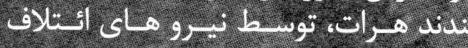

نظامى تا حد امكان، از أرات فرعى عمليات لنامى خونبخ

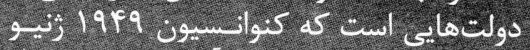
|

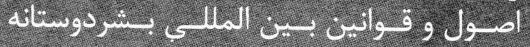
.

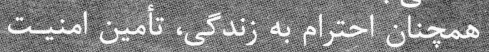

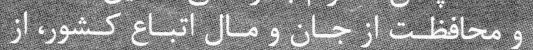

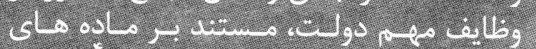

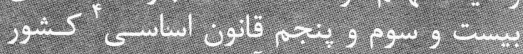

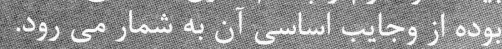

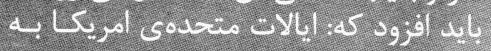

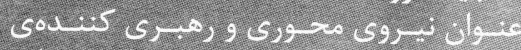

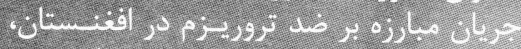

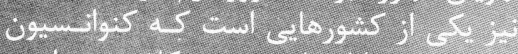

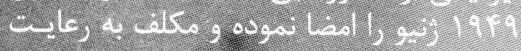

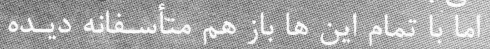

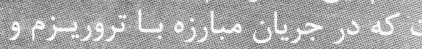

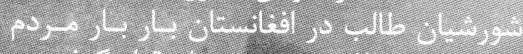

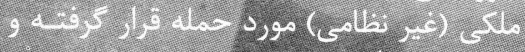
.410 .036 .5

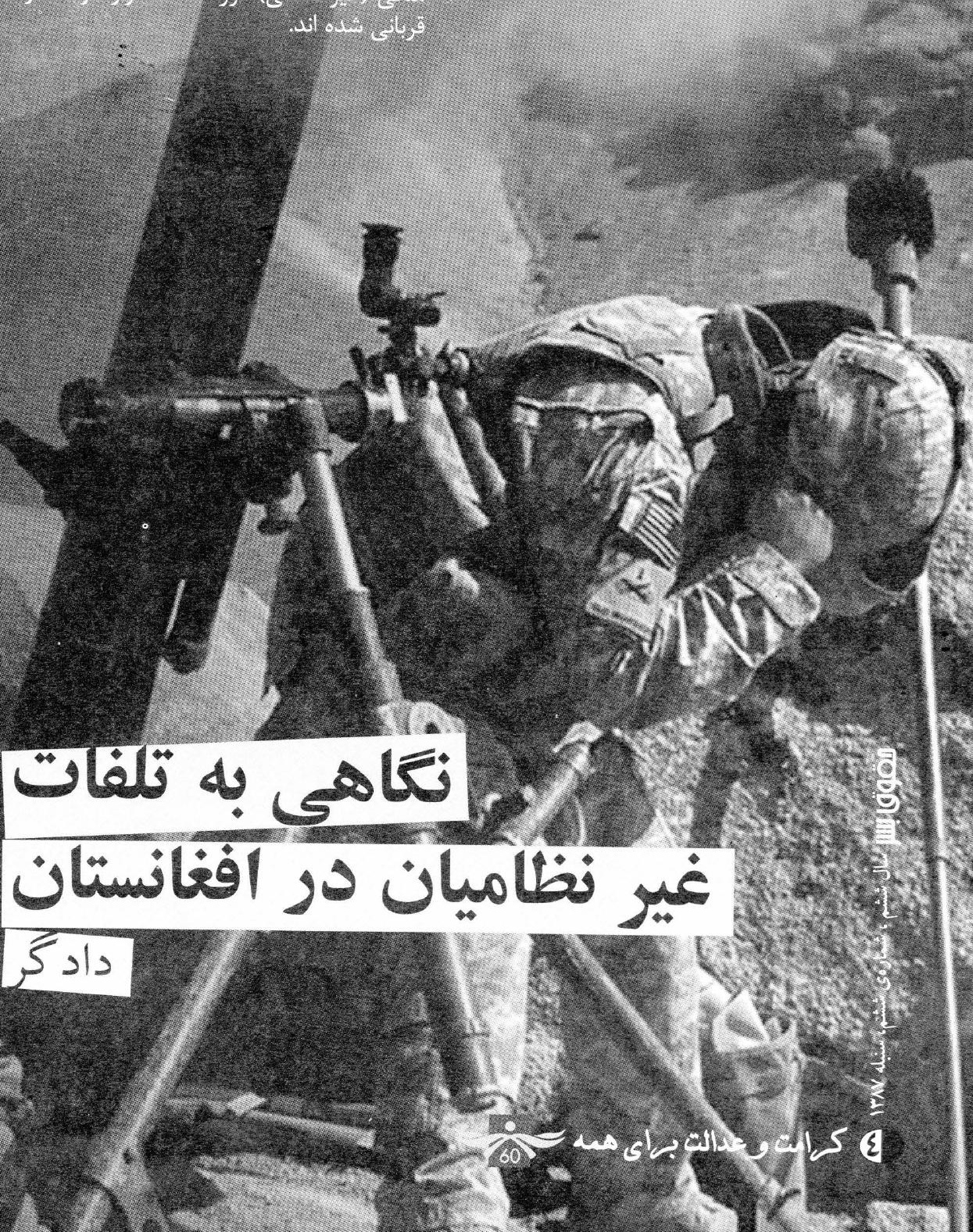

كي از مهم ترين تكلف:هاى دولت هـائ در حال جنا، مبنتي بر تمام قوانين و اسناد

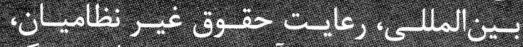

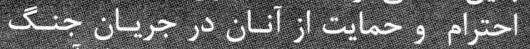

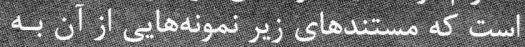
:

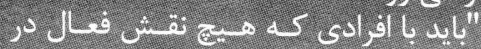

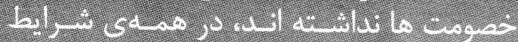

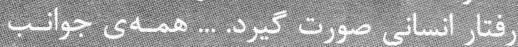

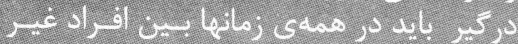

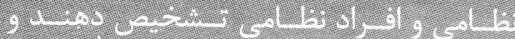

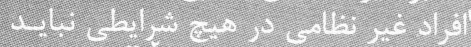


در نتيجهى عمليات نيــرو هـاى ائستلاف بــين

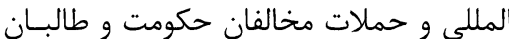
صورت ترفته است

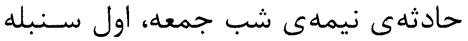

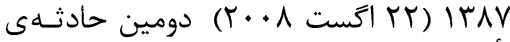

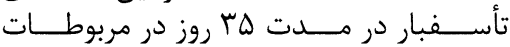

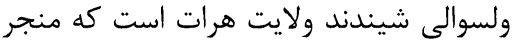
به قربانى شدن تعدادى زيادى از افر افراد ملكى

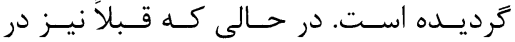
نتيجهى حادثهى

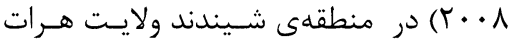

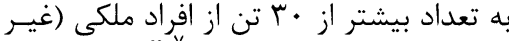

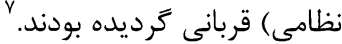

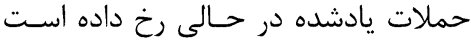

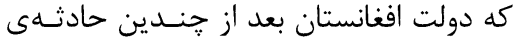

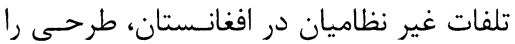

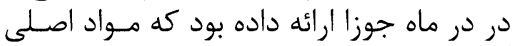
آن را جند بند زير تشكيل مى مدهد ارده

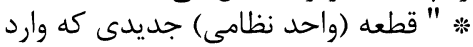
افغانستان مى شود بايد آكاهى كامل دامل در مورد

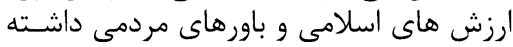
باشند؛

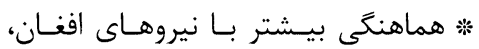

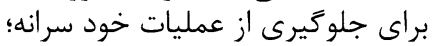

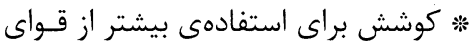

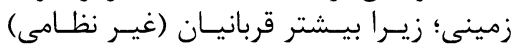
نتيجهى حملات هوايى است؛

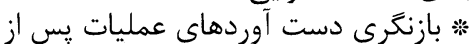

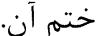

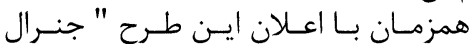

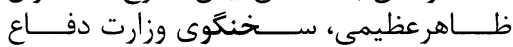

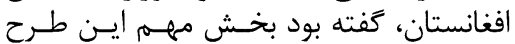

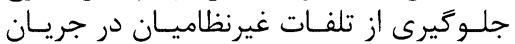

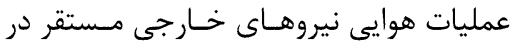

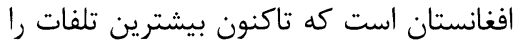

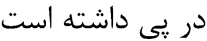

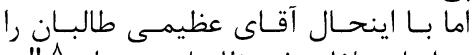

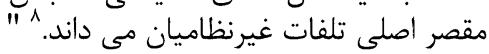

در يكى ديكر از اين حملات كه يَّر سـال

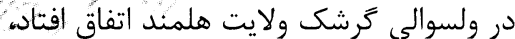

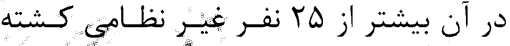

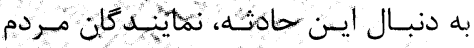

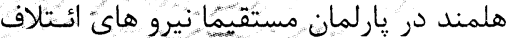

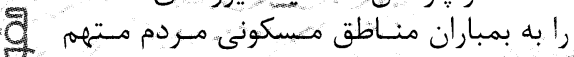

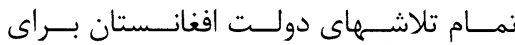

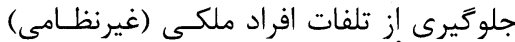
در حالى تأكيد مى كي كند كه به به عدم موفقيـت

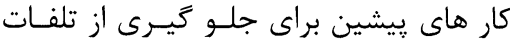

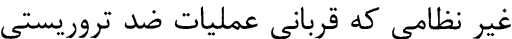
مى شوند اعتراف مى كي كند.

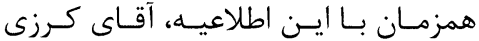

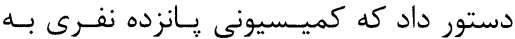
رياست نعمت الله شهرانى، وزير حج و و اوقـاف

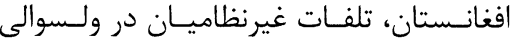

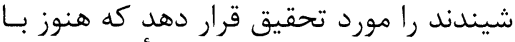

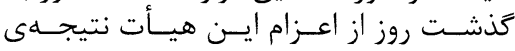

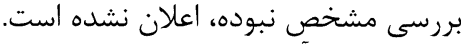

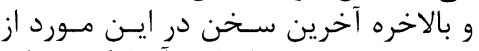

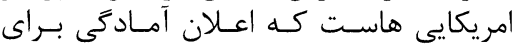

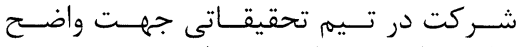

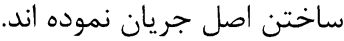

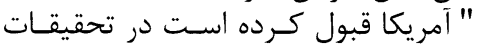

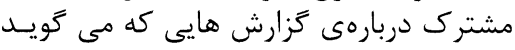

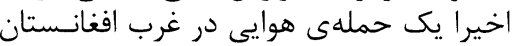

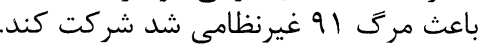
مقام هاى آمريكايى اصرار دارئ دارند كه به بيشتر

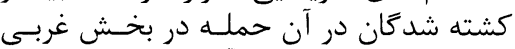

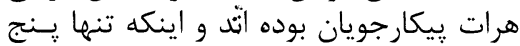
غيرنظامى كشته شدهاند. اين تحقيق به طور مـشترك بـ بـان سـازمان

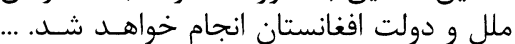
دن مك نورتون، سخنكوى مانفان ماموريت سـازمان

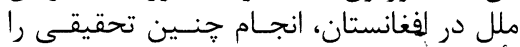

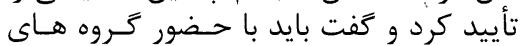
مختلف انجام شود

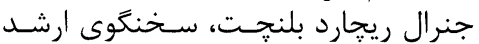

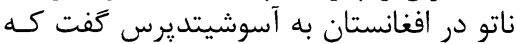

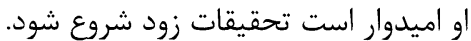

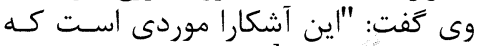

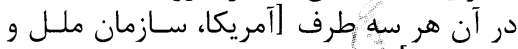

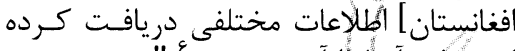

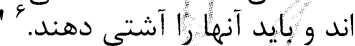

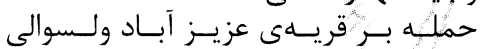

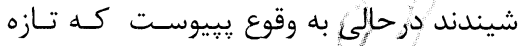

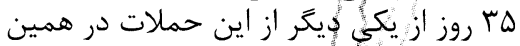

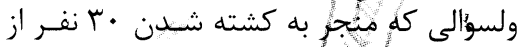

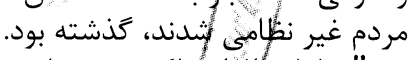

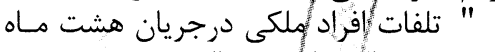

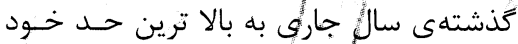

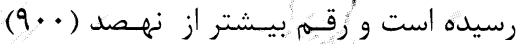
تن از افراد غير نظامى را تشكيل ميى دهد كـهـ

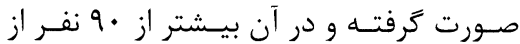

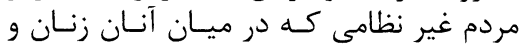

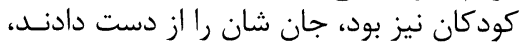

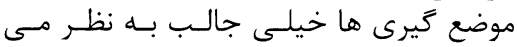
رسد.

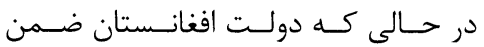

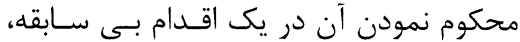

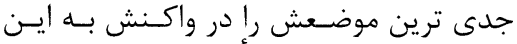

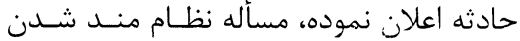

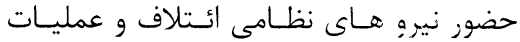

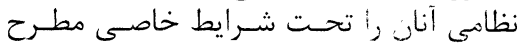

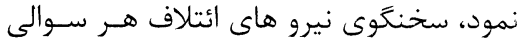
را به حكومست افغانستان ارجـاع داده، هـئيج

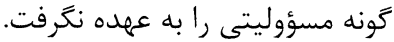

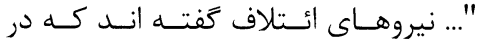

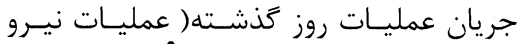

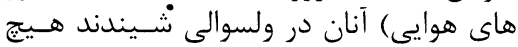

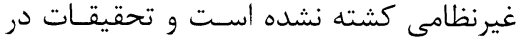
اين زمينه ادامه دارد.

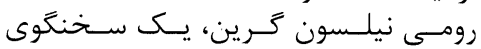

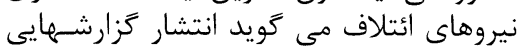

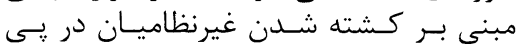

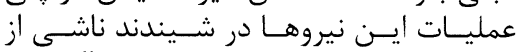

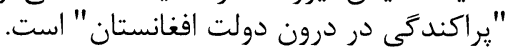

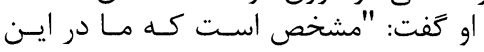

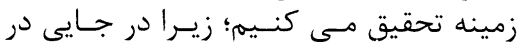

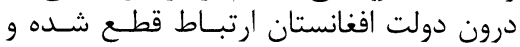

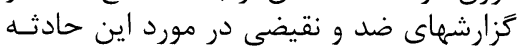

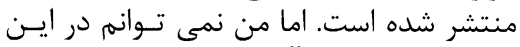

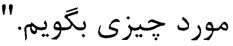

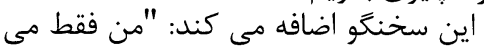

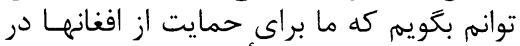

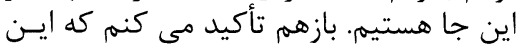

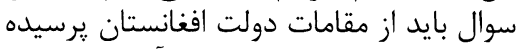

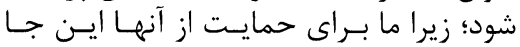

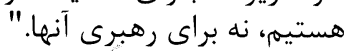

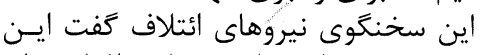

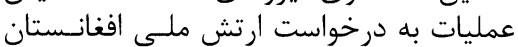

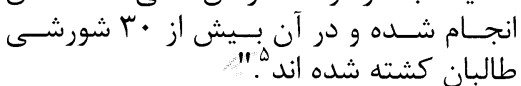

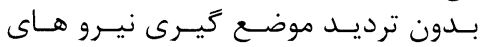

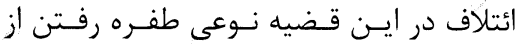

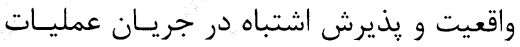

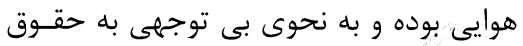
مردم افغانستان مى بـ باشد.

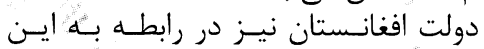

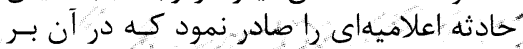

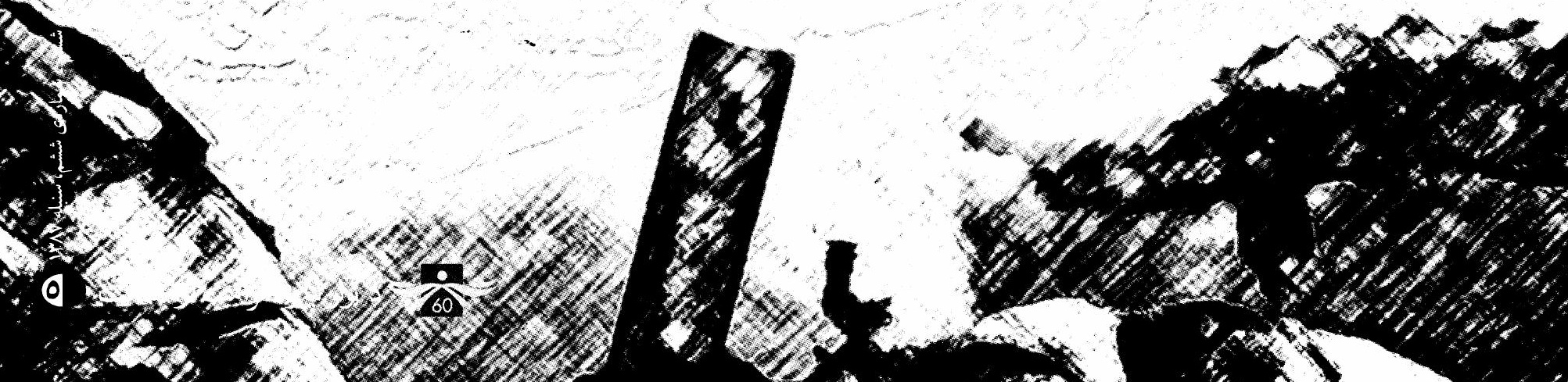




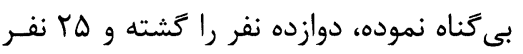

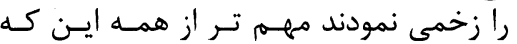

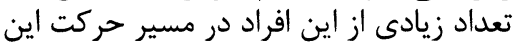

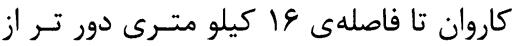

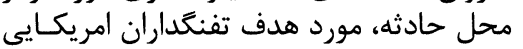

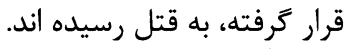

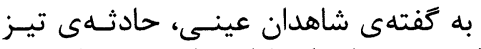

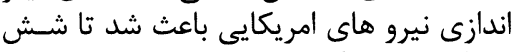

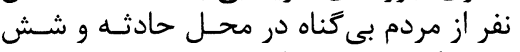

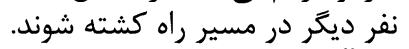

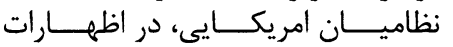

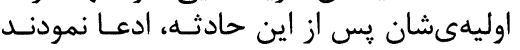

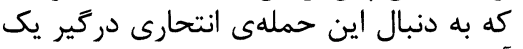

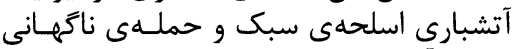

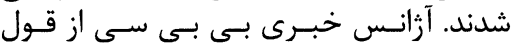

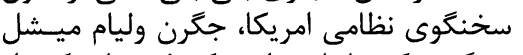

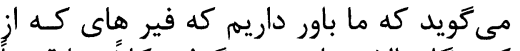

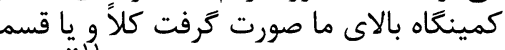

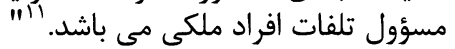

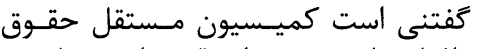

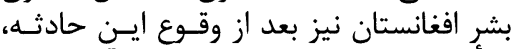

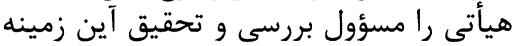

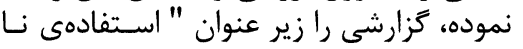

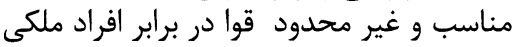

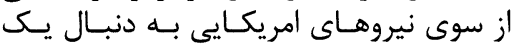

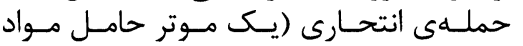

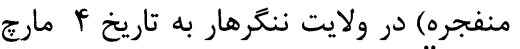

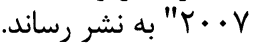

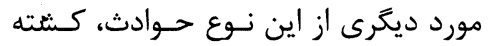

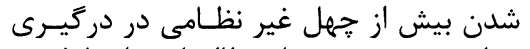

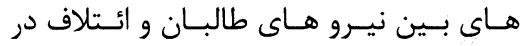

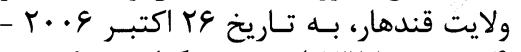

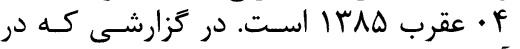

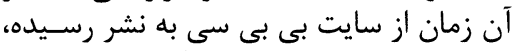

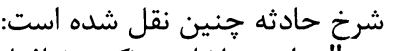

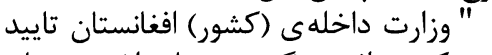

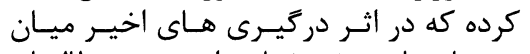

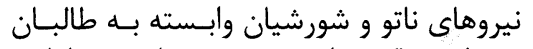

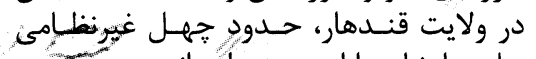

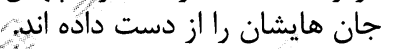

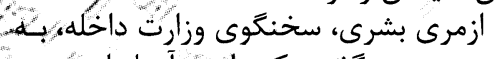

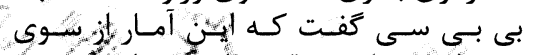

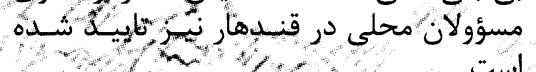

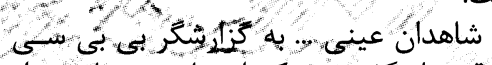

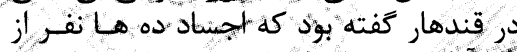

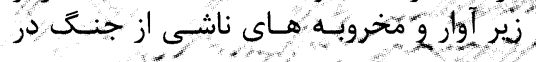

بى توجهى شان به منتفذان و سران قـوميى و

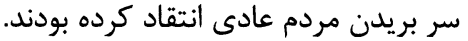

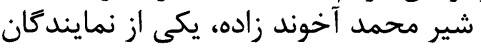

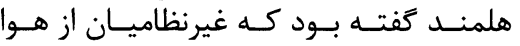

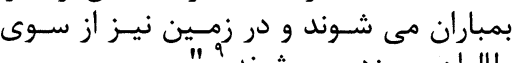
طالبان سر زده مي شوند شوند

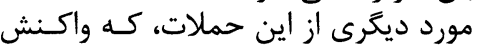

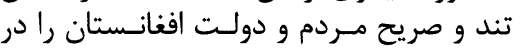

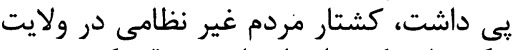

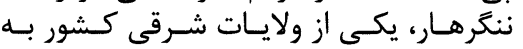

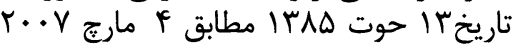

در آن زمان، رئيس دولت جنين حملاتسى

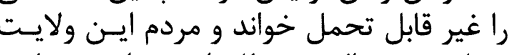

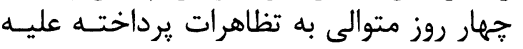

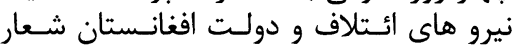
دادند. درست بعد از وقوع ايسن حادثـه بـود كـهـ

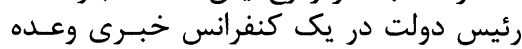

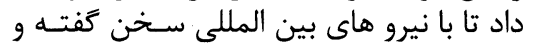

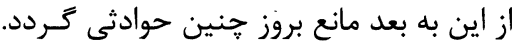

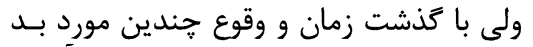

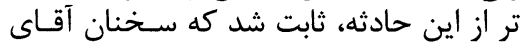

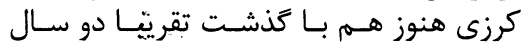
نتوانسته است عينيت ييدا كند.

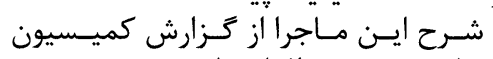
مستقل حقوق بشر افغانستان:

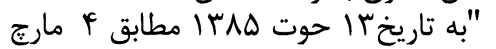

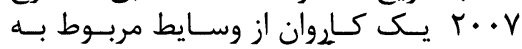

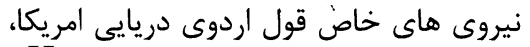
متشكل از ه ها 4 أموتر هوم وى (Humvee)

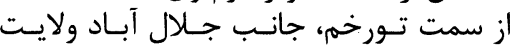

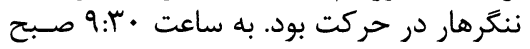

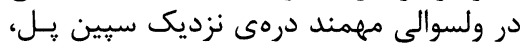

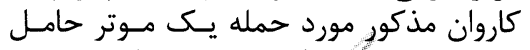

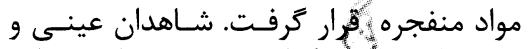

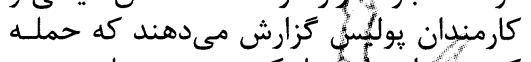

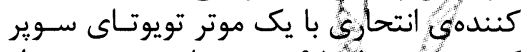

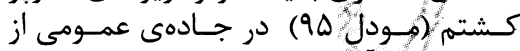

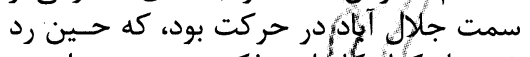

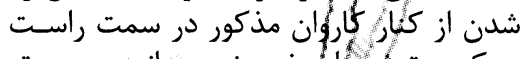

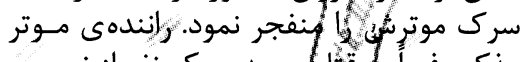

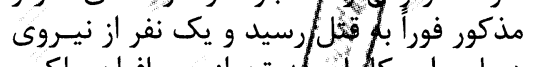

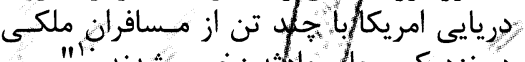

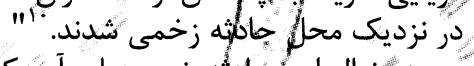

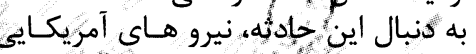

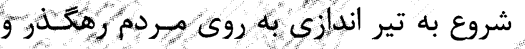

"اين نمايندگان مى گويند در اغلب موارد

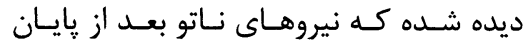

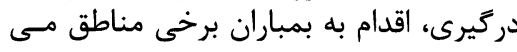

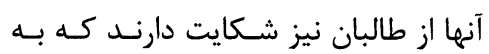

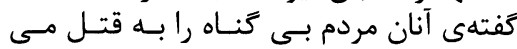

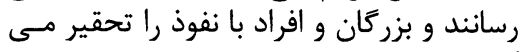

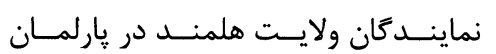

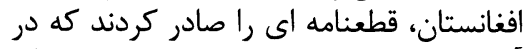

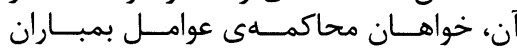

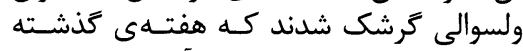

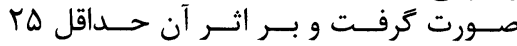

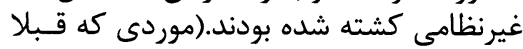
به آن اشاره شده بودئ

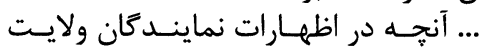
هلمند تازه به نظر مي رسد اين است كه آنها آنها

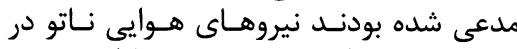

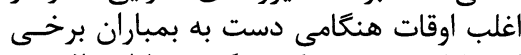

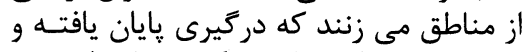

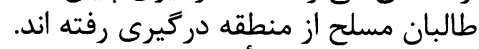

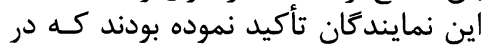

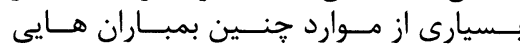

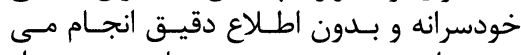

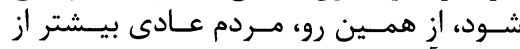

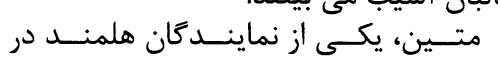

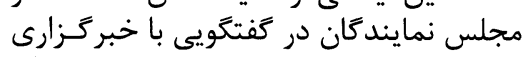

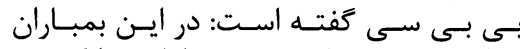

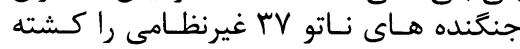

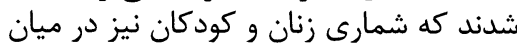

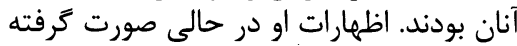

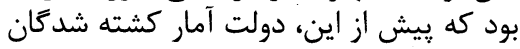

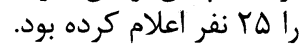

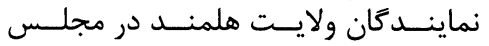

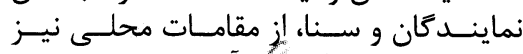

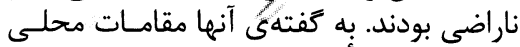

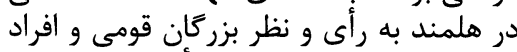

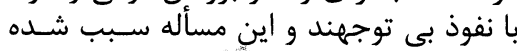

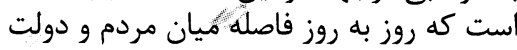
بيشتر شود.

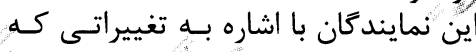

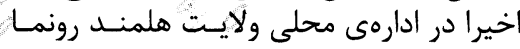

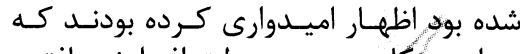

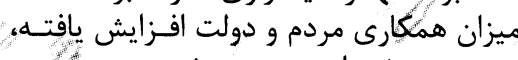
در نتيجه وضع امنيتى بهارى مردم دولت شود.

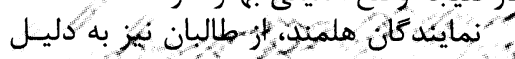

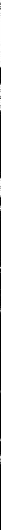




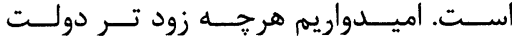
افغانستان در همكارى با جامعهى بـ بين المللـى

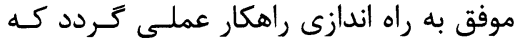

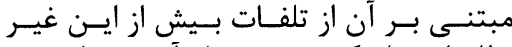

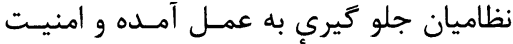
مردم غير نظامى تأمين گردي بهد.

\section{يَنوشت:}

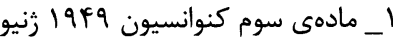

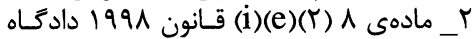
جنايى بين المللى روم

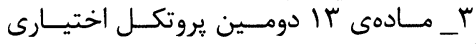

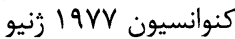

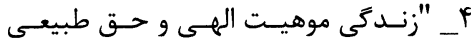

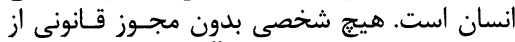

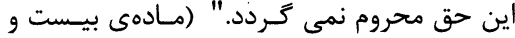

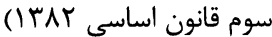

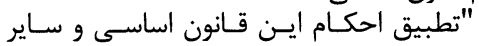

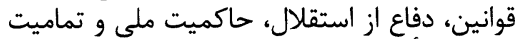

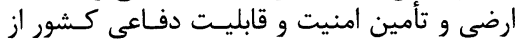

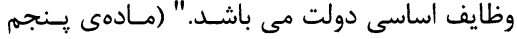

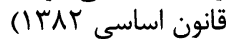

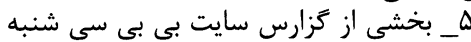

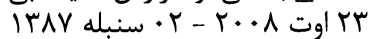

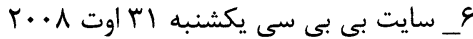

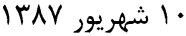

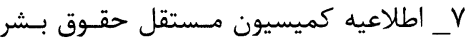

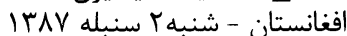

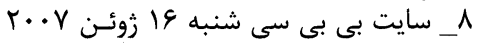

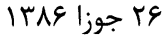

9

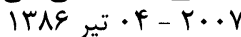
•

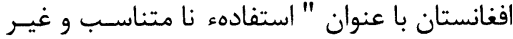

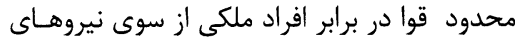

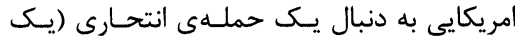

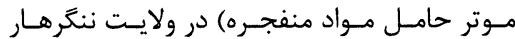

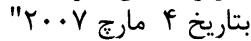

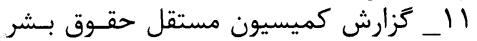

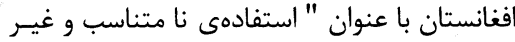

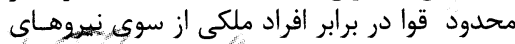

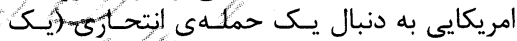

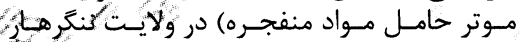

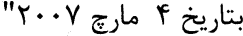

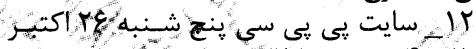

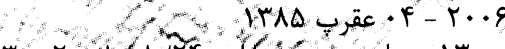

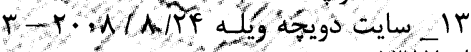

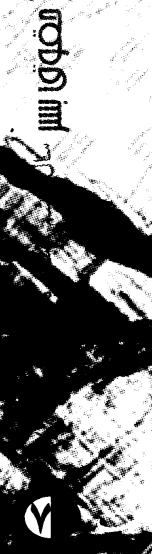

سنبله

\section{$+\infty$}

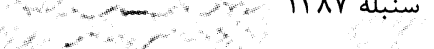

نور الحق علومى، نمايندهى مردم قنــدهار در ولسى جركه مي گَويد:

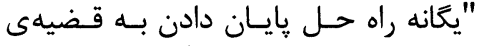

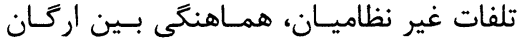

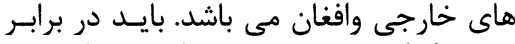

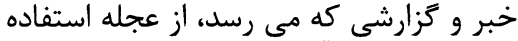

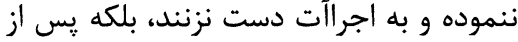

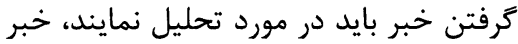

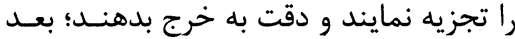

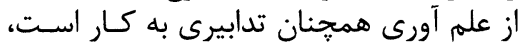

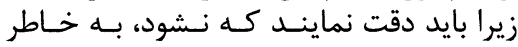

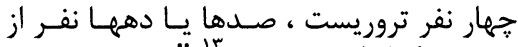
مردم بى حملات انتحارى تعدادى از افرين برواد غاند يوشش طالبان و تروريزم بين المللى كاري كه جان اندان

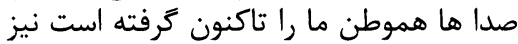

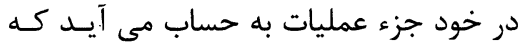

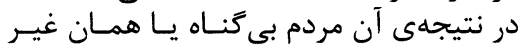

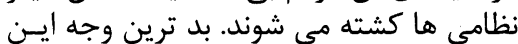

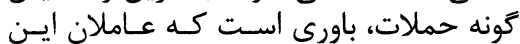

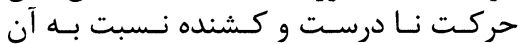

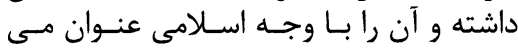

طورى كه مى دانيم اين حملات هميـشه

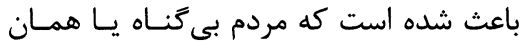

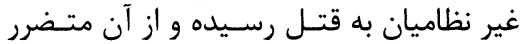

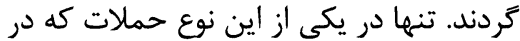

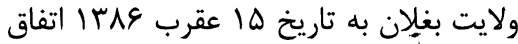

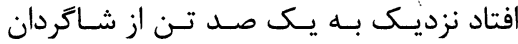

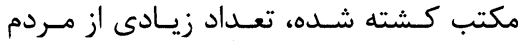

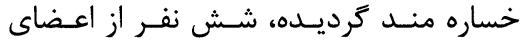

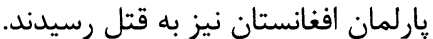

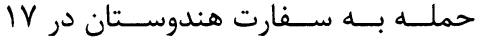

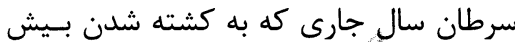

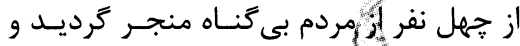

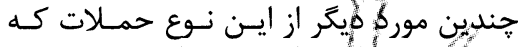

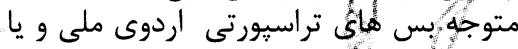

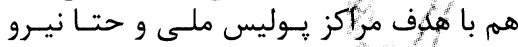

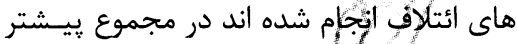

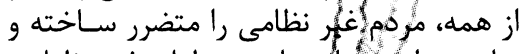

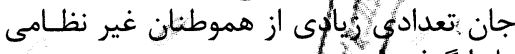

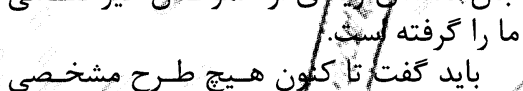

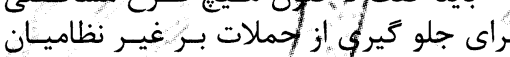

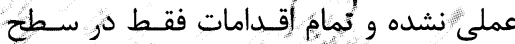
سخن و يا هم فيصلنهاى بر كاغذ بـاقي ماتنده
ولسوالى هاى زيرى و ينجوايى قندهار

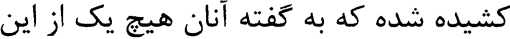

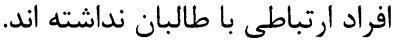

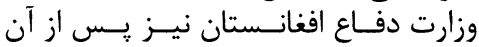

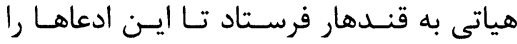

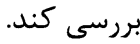

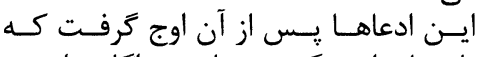

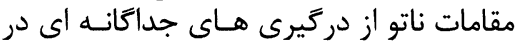

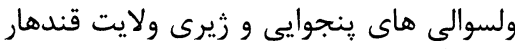
خبر داده بود. در آن زمان ناتو در يكى اعلاميه كَتته بود:

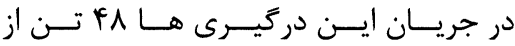

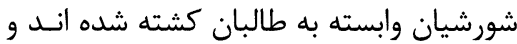

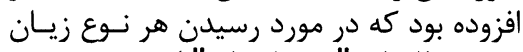

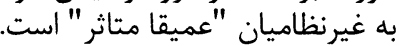

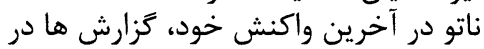

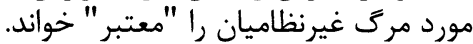

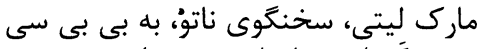

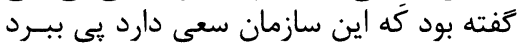

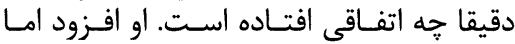

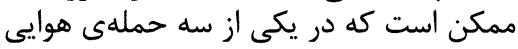

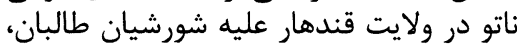

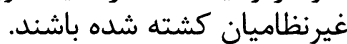

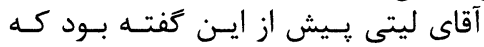

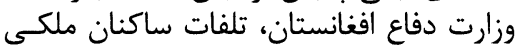

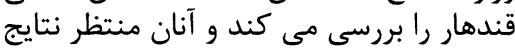
اين تحقيقات هستند

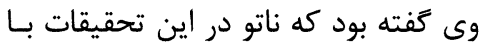

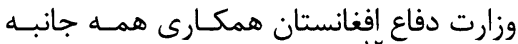

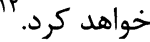

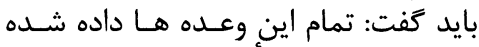

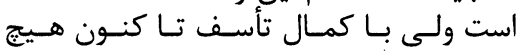

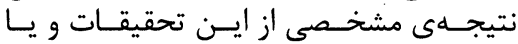

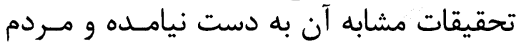

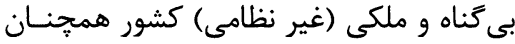

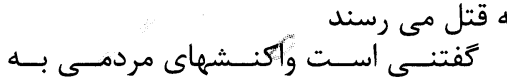

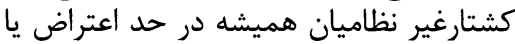

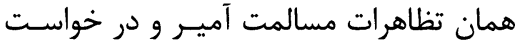

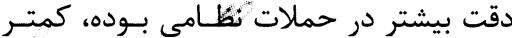

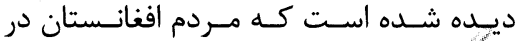

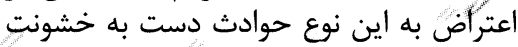

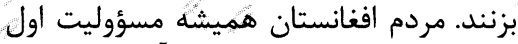

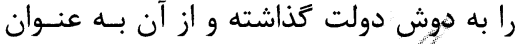

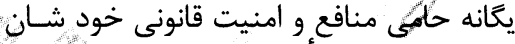

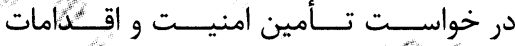

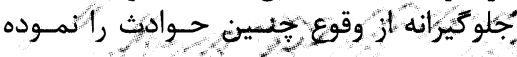

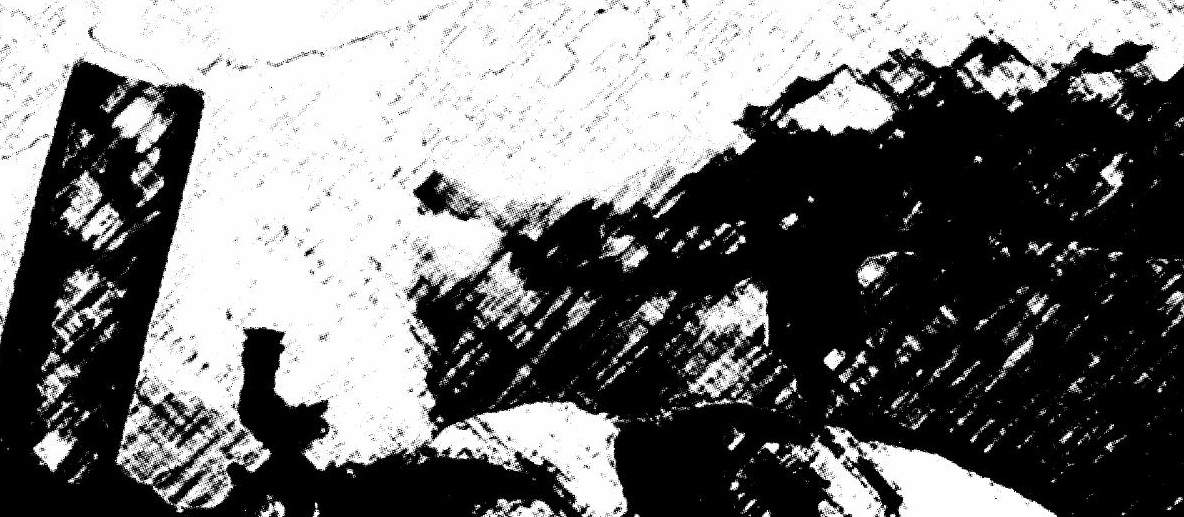




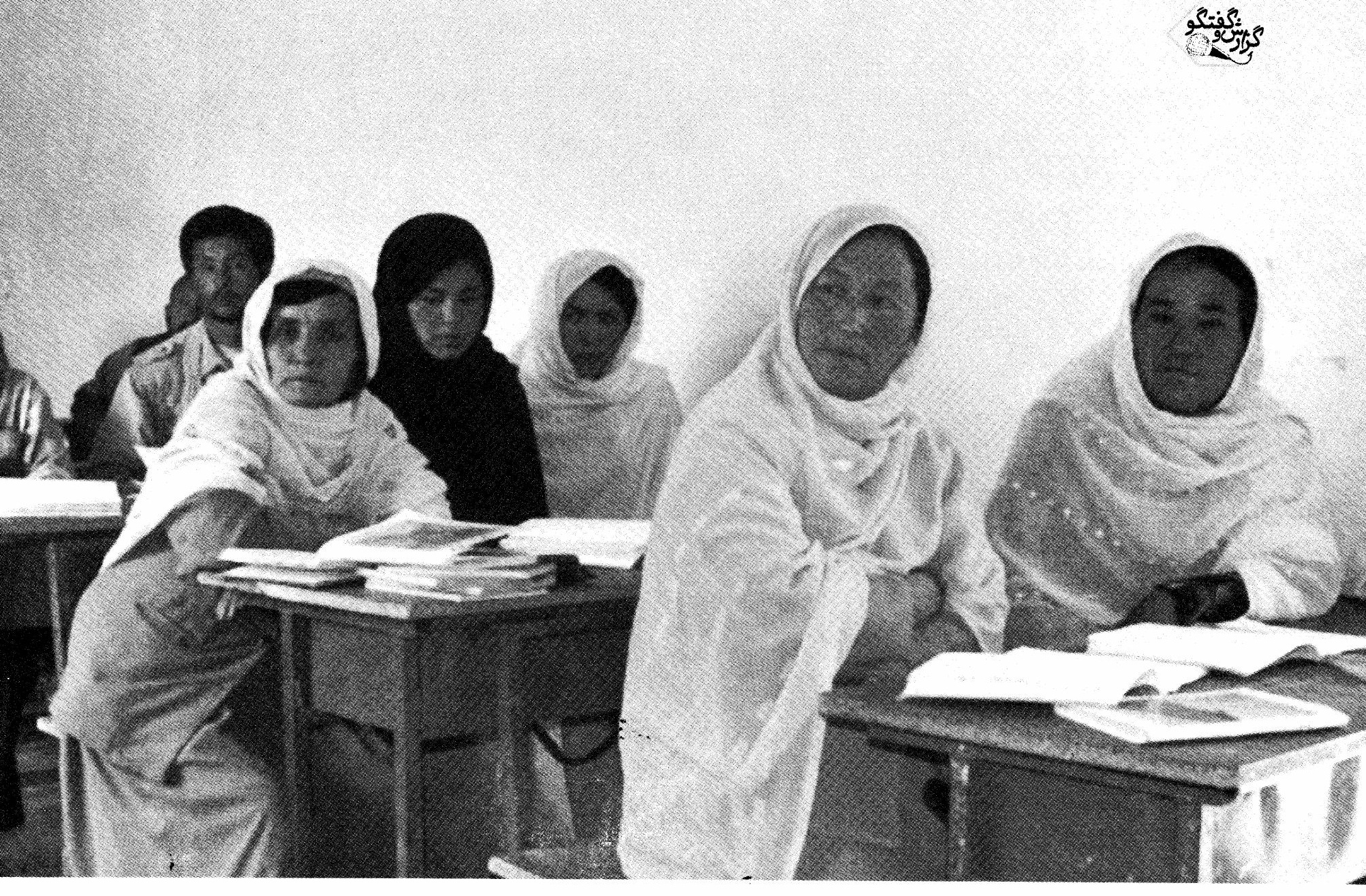

\section{د سواد نزيواله ورحُ او يه افغانانوكي دليك لوست تيتّه كجها}

خبريال: خوشال خليل

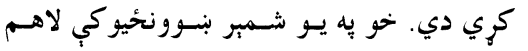

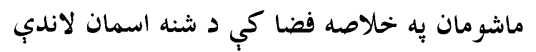

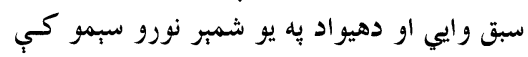

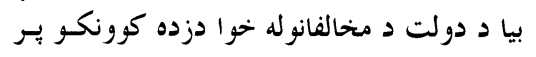

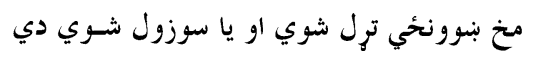
او دا لرى لا روانه ده.
\end{abstract}

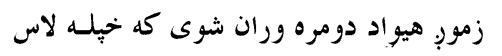

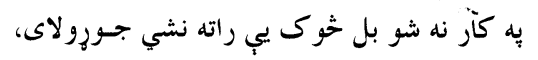

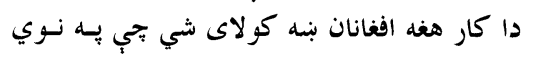
تكنالوزى او يوهي سمبال وي.

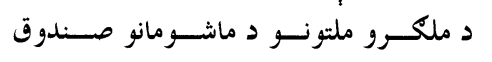

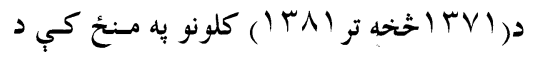

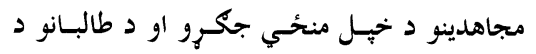

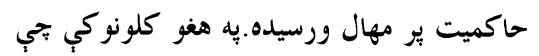

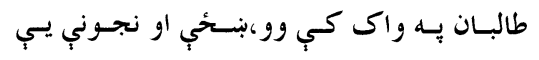

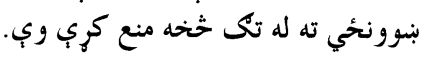

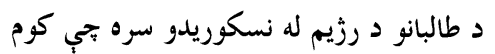

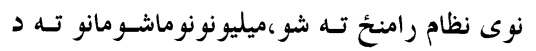

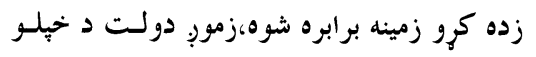

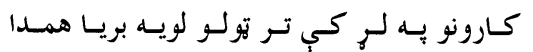

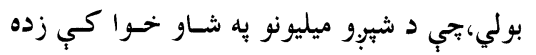

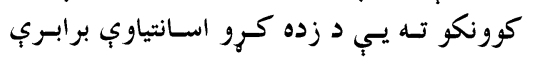

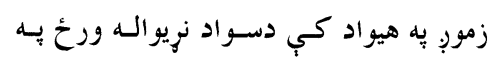

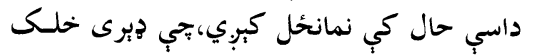

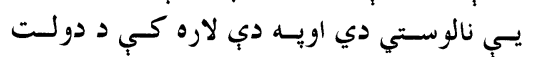

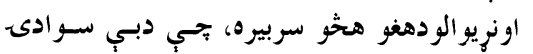

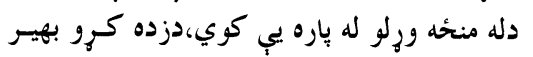

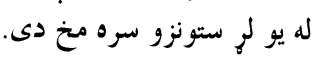

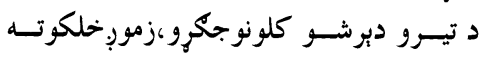

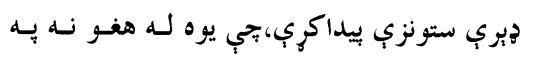

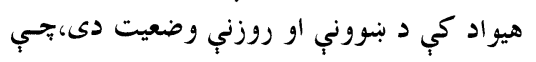

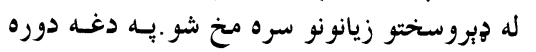

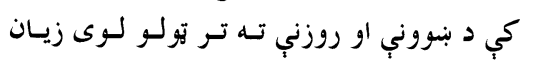


دبناغلي جم يه وينا د يوهني وزارت تيركسال

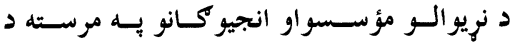

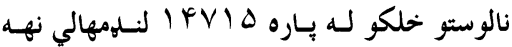

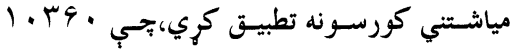

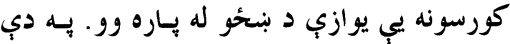

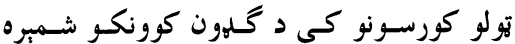
(

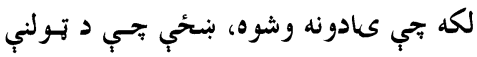

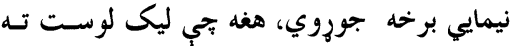

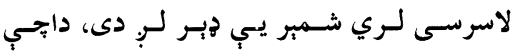

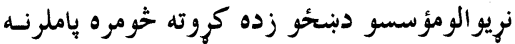

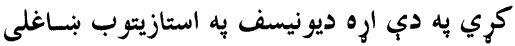

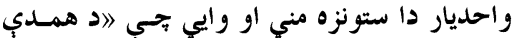

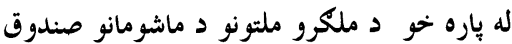

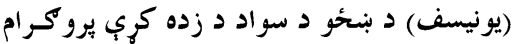

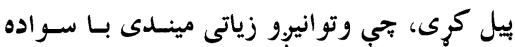

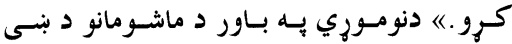

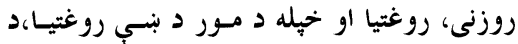

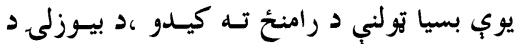

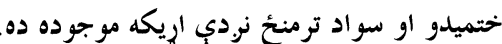

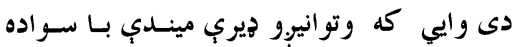

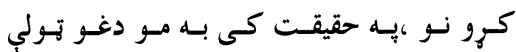

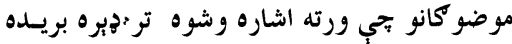

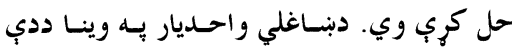

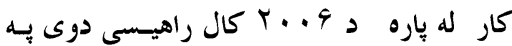

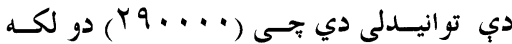

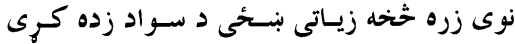

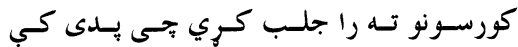

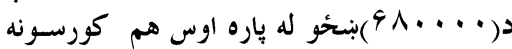

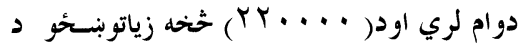

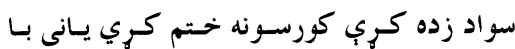

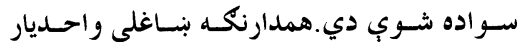

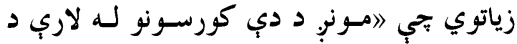

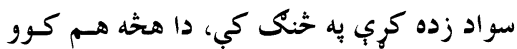

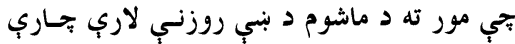

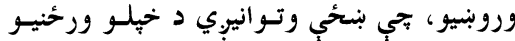

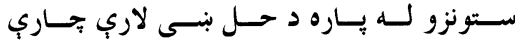

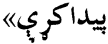

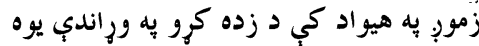

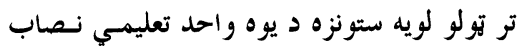

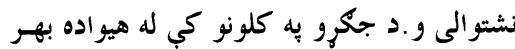
او ددننه د يـو شـمبر هلو او تنظمونسو لـه خهوا

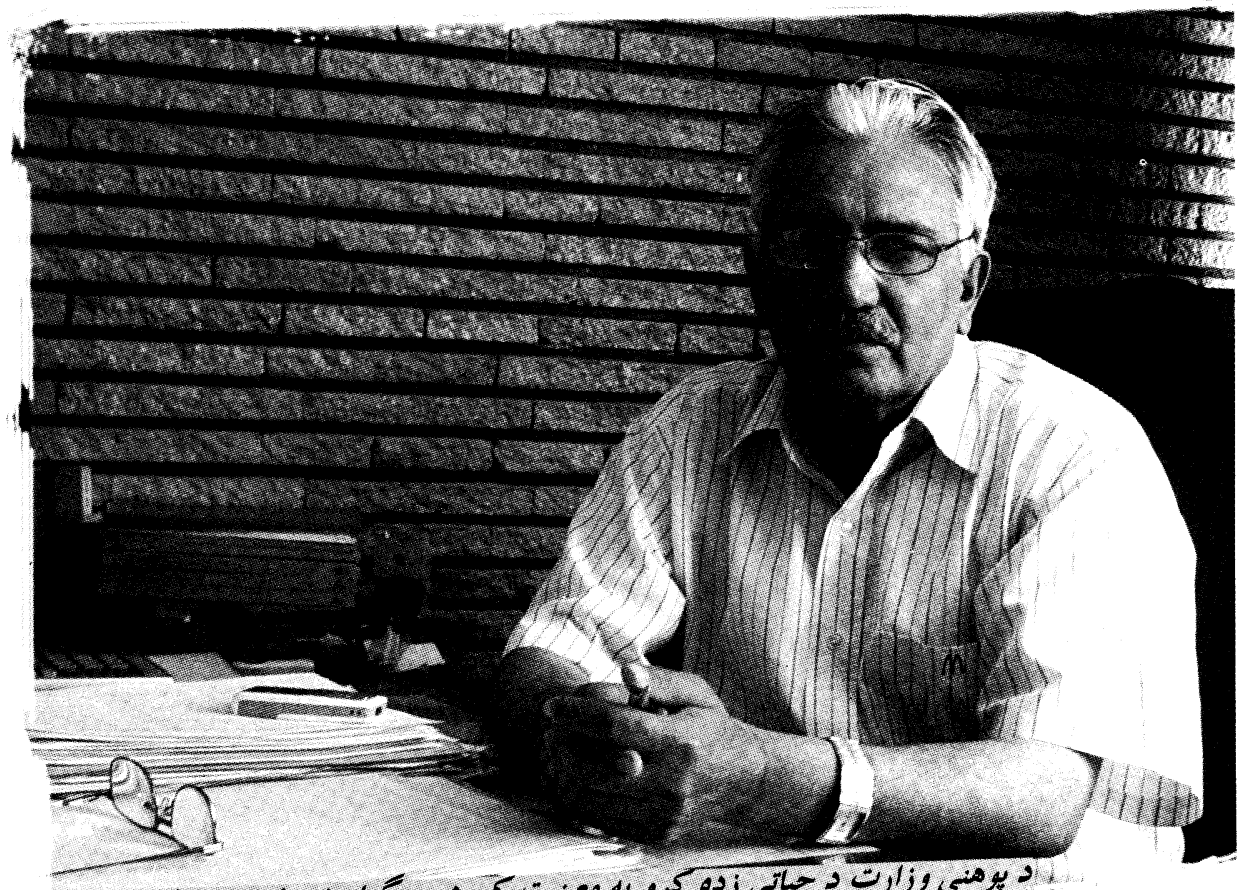

. بوني وزارت د حياتي زده كرو له بعينيت كي د بروكرامونو رئيس نباغلي الله بازجم.

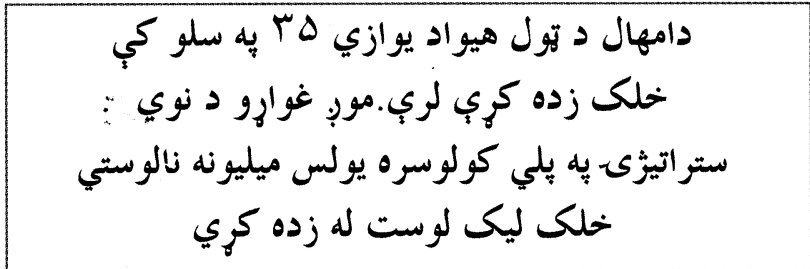

جي بهه راتلونكي كـي بـه يـو بـ سـواده هيسواد ولرو.

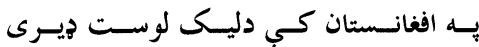

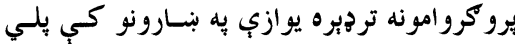
كبدل او دلري يرتو سبمو خلكى ورنه بي برخي

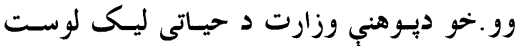

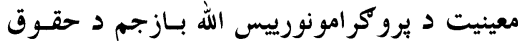

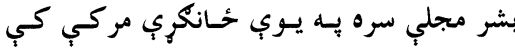

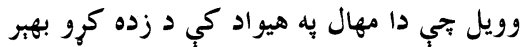
يو نسوي يهـاو تسه ور ننسوتى دى او دوى دئ ده نسوي

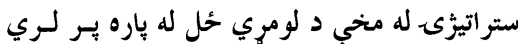

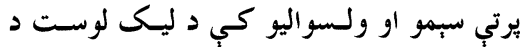
يروكر امونو لرئ بيل شويده. بنساغلي الله بـاز جسم وايسي" دامهـال د دتهول

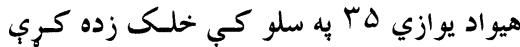

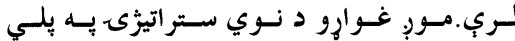
كولوسره يسولس ميليونسه نالوستي خلـك ليسك

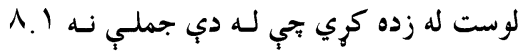

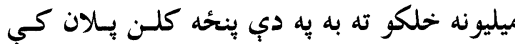

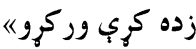

(يونيسف)يه افغانستان كي د ليك لوست حالت دوالت

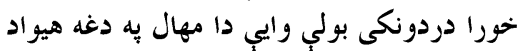

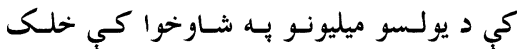

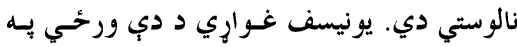

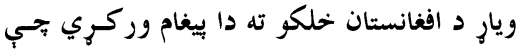

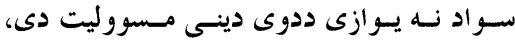

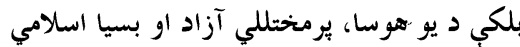

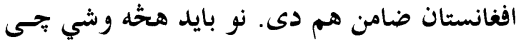

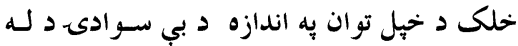

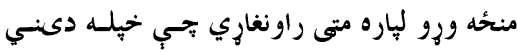

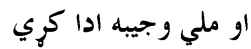

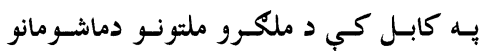

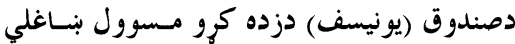

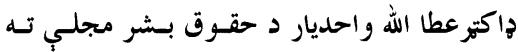

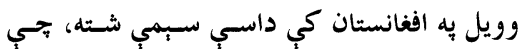

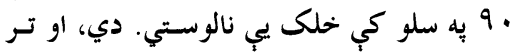

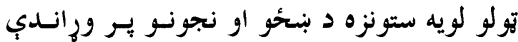

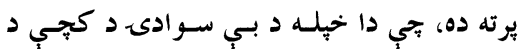

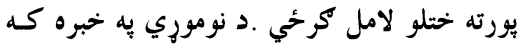
دا حالت همداسي دوام وكري د دي ويره شسته، 
زيات نه زيات خلك دسواد به اهميت بوه شي ·

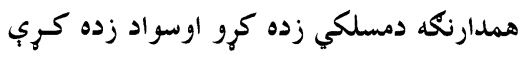

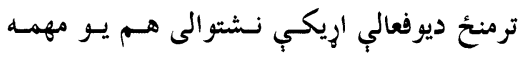

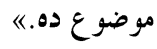

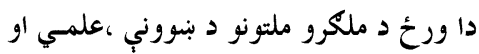

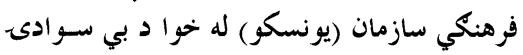

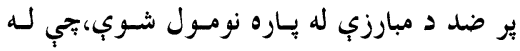

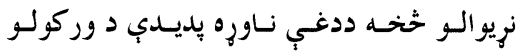

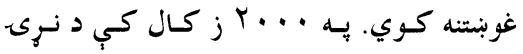

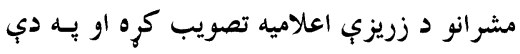

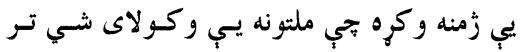

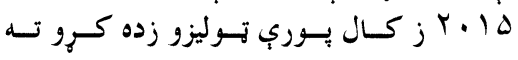

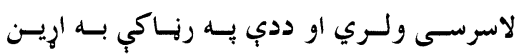

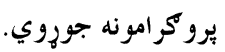

دولتونه بِه هره برخه كي خحانكيكي سـتراتيزّى

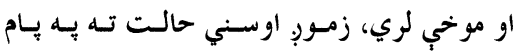

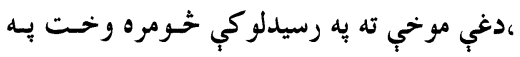

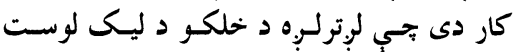

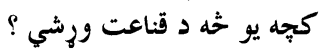

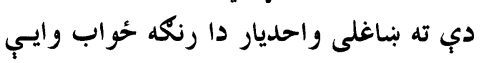

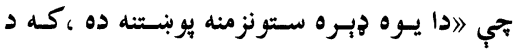

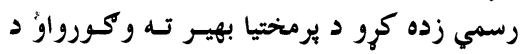

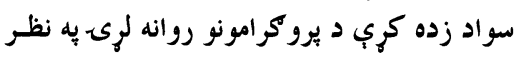

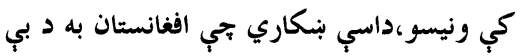

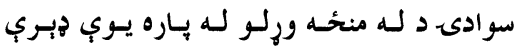

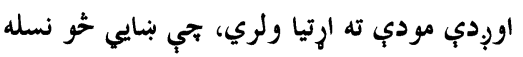

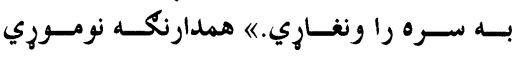

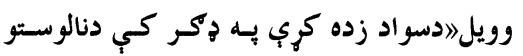

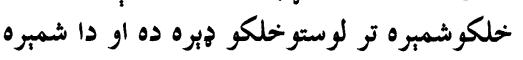

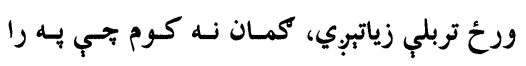

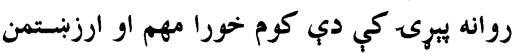

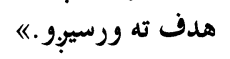

خو بناغلى الله بازجم بياديوهني به برخه كي

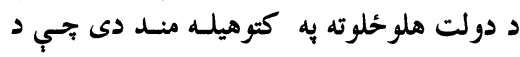

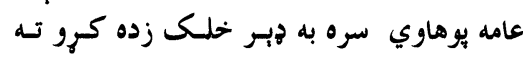

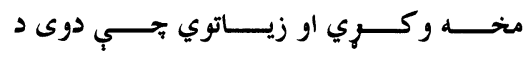

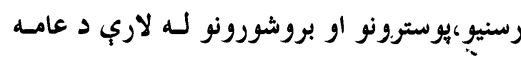

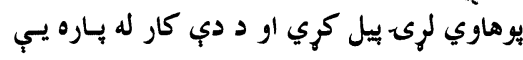

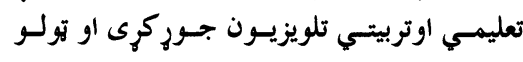

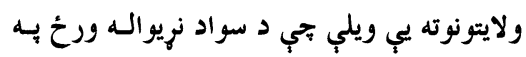
يرتمينومر اسمو ونمانحئي.

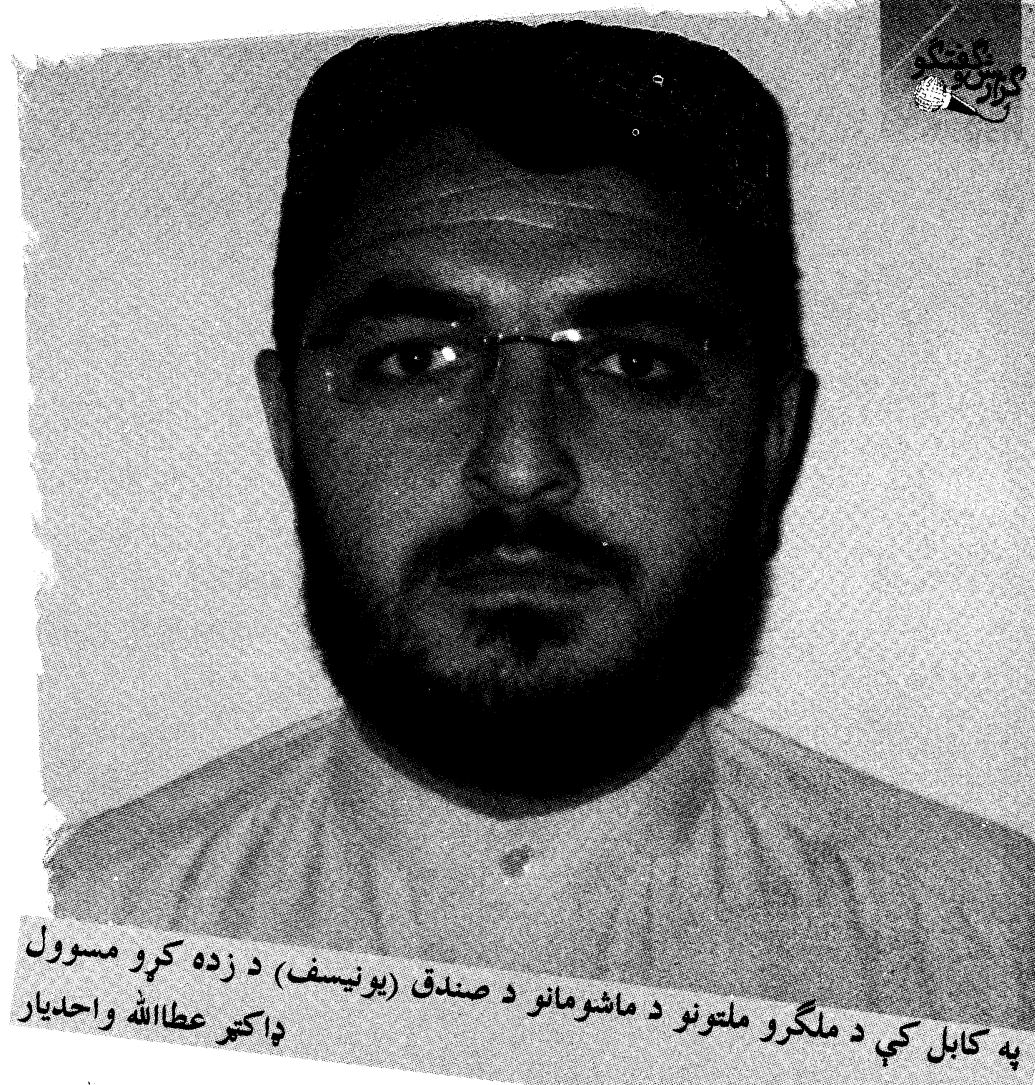

كه دهيو اد نفوس ه Y ميليونه اتكل كرو نو نزدى نيم

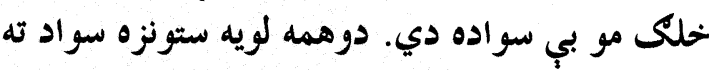

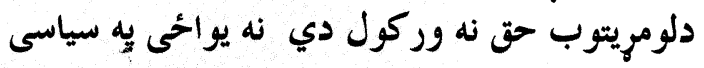

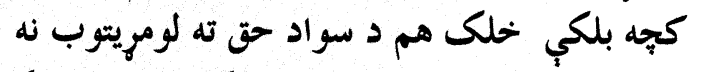

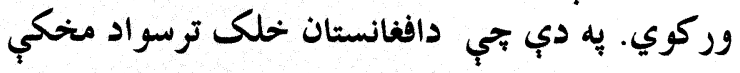
نور نيو لومريتوبونه لوي

او وايي لا ترتولو لويه سـتونزه اوخنسله بـه خهيله

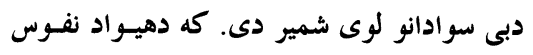

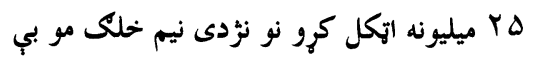

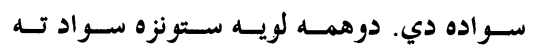

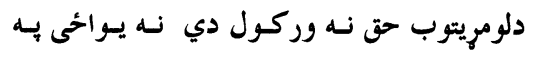

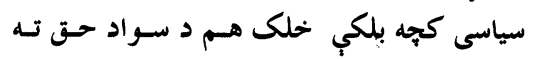

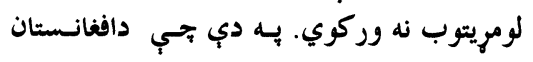

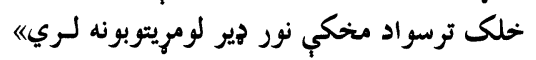

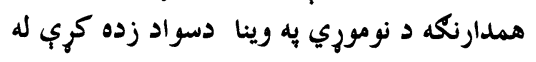

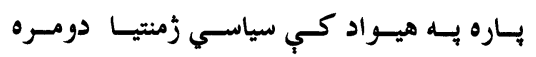

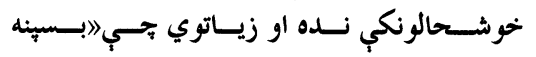

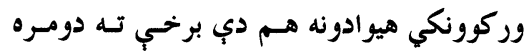

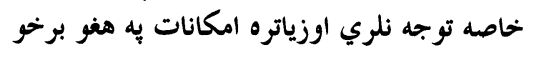

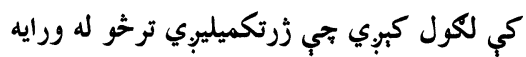

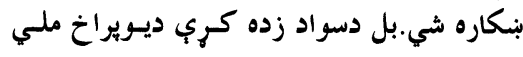

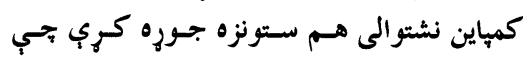

بيلاببل نصابونه جور شوي وو.هر جـا غوبنستل د تعلميي نصاب له لاري خحيلسه سياسي ايسديالوزي

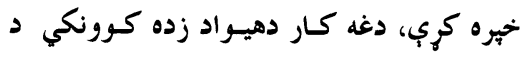

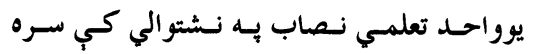

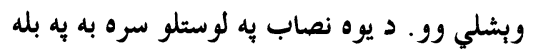
سبمه كي له يوله ستونزو سره مخ كبد كبدل.

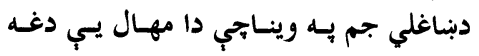

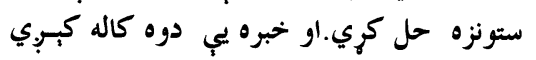

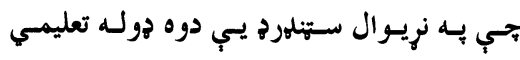

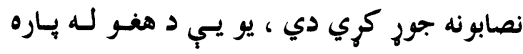

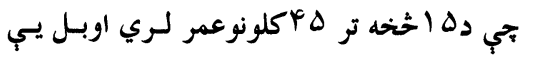

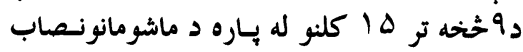
جور كرى دى. خو بناغلى عطا الله واحديار بيـا د زده كري

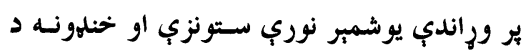

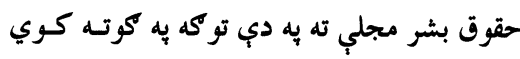





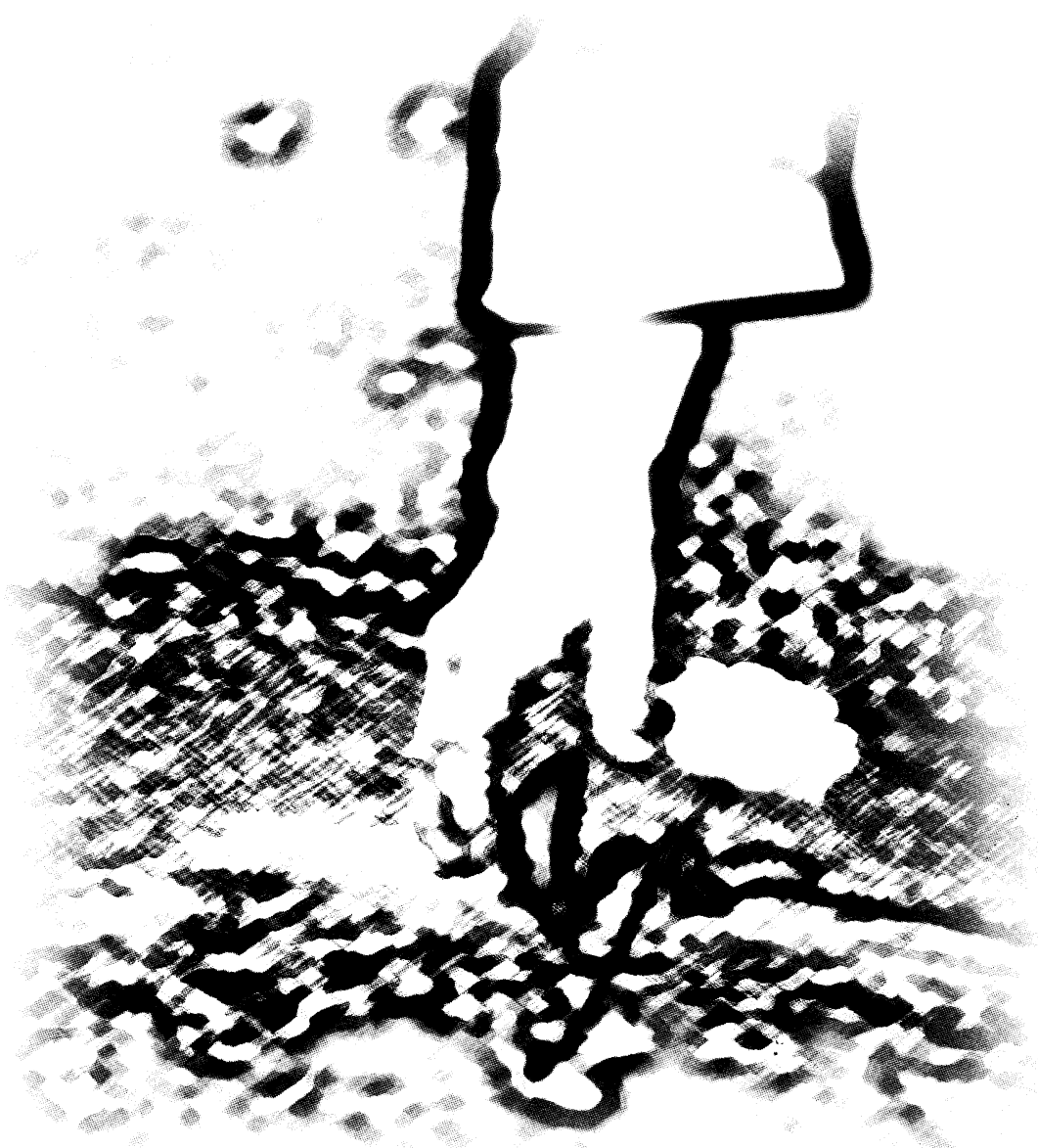

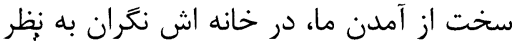

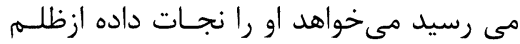
اين خانه رهايش رهم رهم.

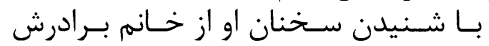

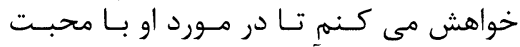

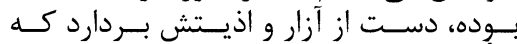

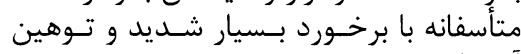
آميز او بر مى خـو خورم.

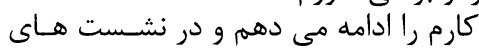

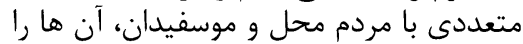

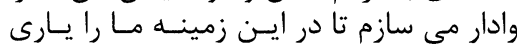

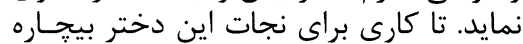

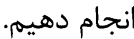

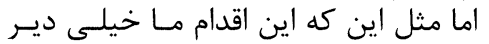

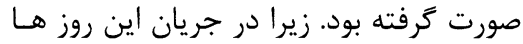

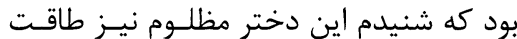

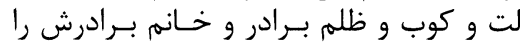

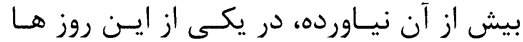

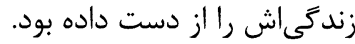

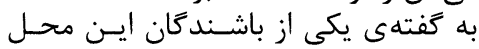

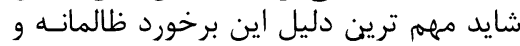

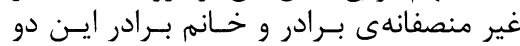

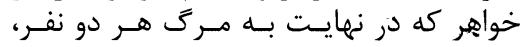

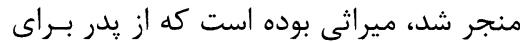

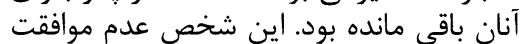

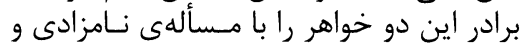

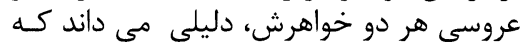
مى تواند نيت برادر و خانمش درو را آشكار سازد.

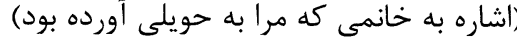
كه حالا شما را به حويلى آورد يكسال يــيش

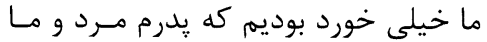

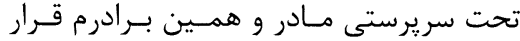

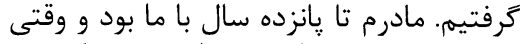

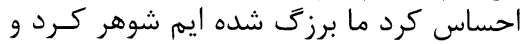

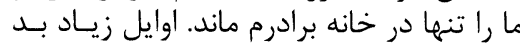

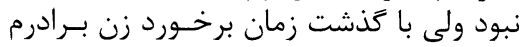

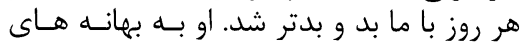

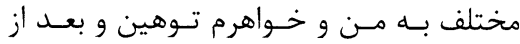

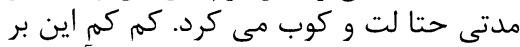

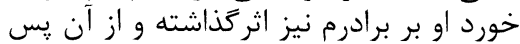

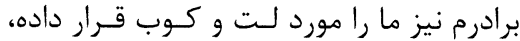

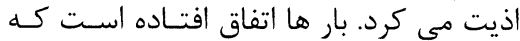

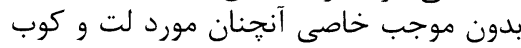

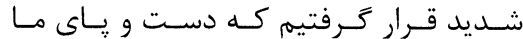

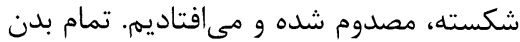

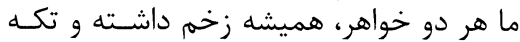

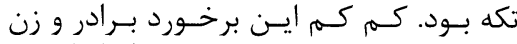

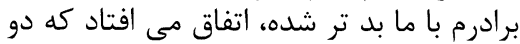

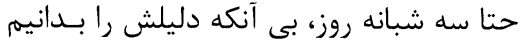

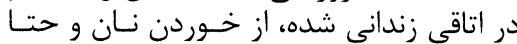

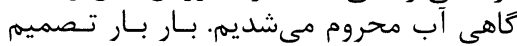

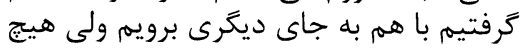

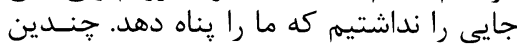

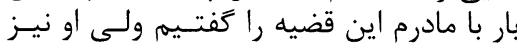

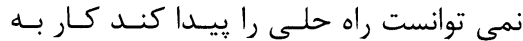

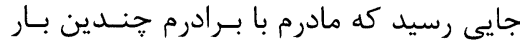

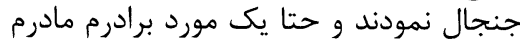

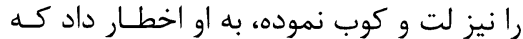

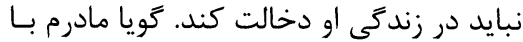

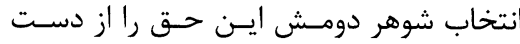

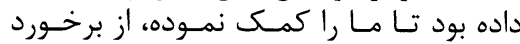
ظالمانهى برادرم انتقاد كند.

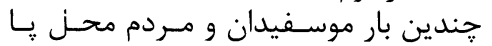

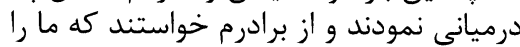

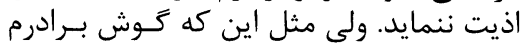

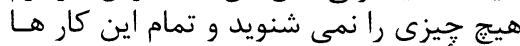
هيجج تأثيرى بر او نداشت ندئ.

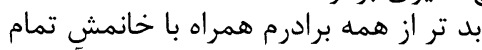

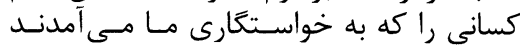

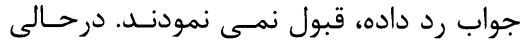

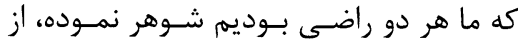

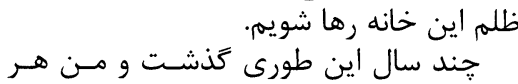

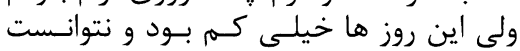

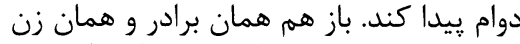

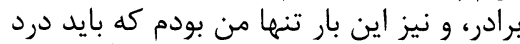

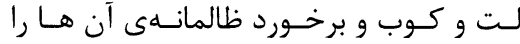

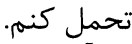

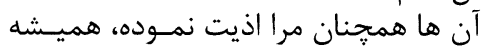

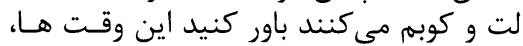

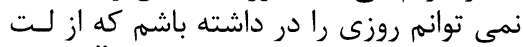

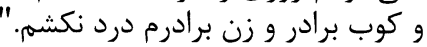

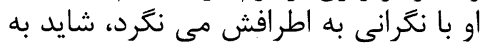

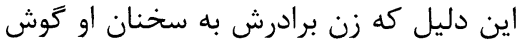

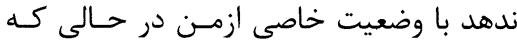

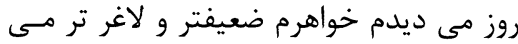

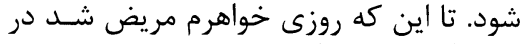

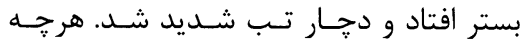

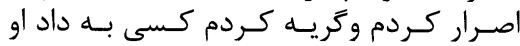

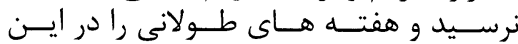

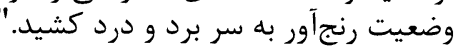

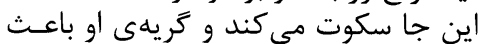

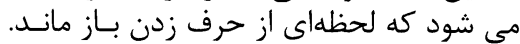

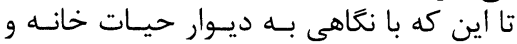

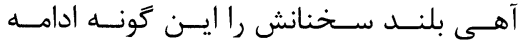




\section{هيو لاكى وحشت \\ يا تجاوز جنسى بر كود كان}

\section{لاله احمدى لركي}

افغانستان " منتشر نموده بود، آمده است:

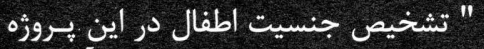

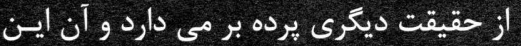
كه ميزان آسيب بذيرى دختران بـ به تناسب

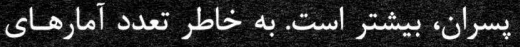

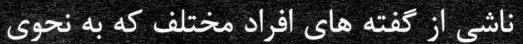

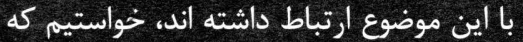

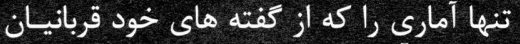

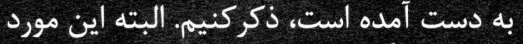

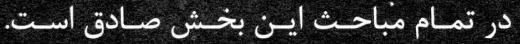

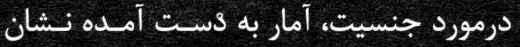

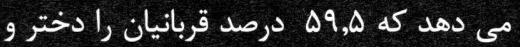
ra,l

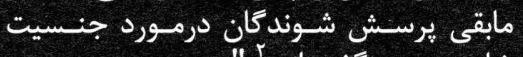

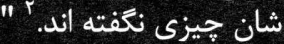

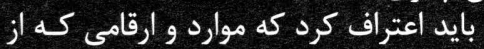

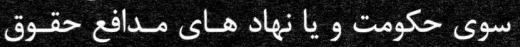

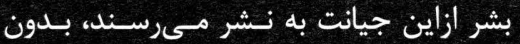

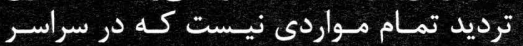
كشور اتفاق مى افتل. بلكه اين ها تنها مـورارد

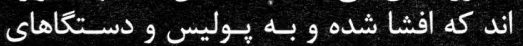

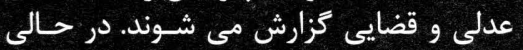

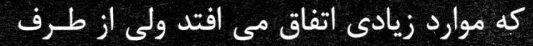

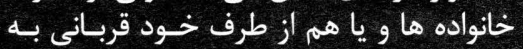
دلايلى كه بيشتر تـرس از آبرو و و مـسايلى از

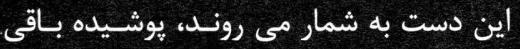
مانده، هر زَ افشا نمى شوند.

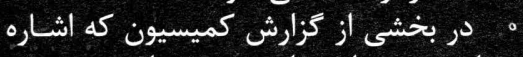
به اين مورد داشته است مى خواني كوانيم:

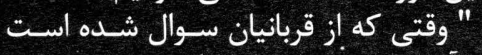

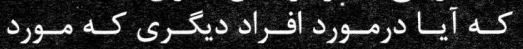
استفادهى جنسى قرار كرفته اند جيـزى مرى
تجاوز جنسى بر كودكان يكى أزدرناك ترين فجايعى است كله مناسـفانه ايـن اوراختر

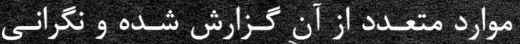
هاى جدى را به بار آروره است.

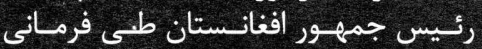
عاملان اين جنايت هولناك را محكوم به اشد

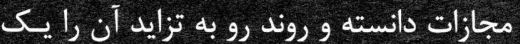

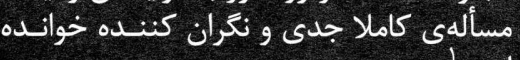
در نخستين موردى كله از اين وقعيت درد ناك، امسال از طريق رسانه ها به نشر رسـيد

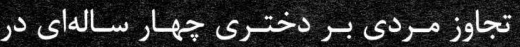

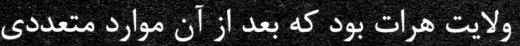

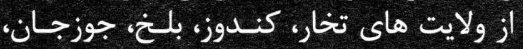
سريل، بدخشان و كابل كزارش شار شده اند.

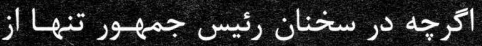

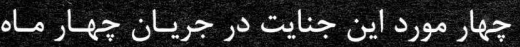
اخير تذكر به عمل آمله است ولى الى به كفتله

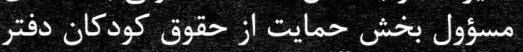

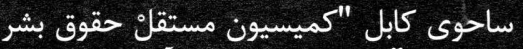
افنانسنان " در يك سال اخير آهـار كودكانى كه مورد تجاوز جنسى قرار كرفته اند بالا تر

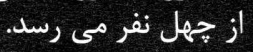

$$
\text { جنسيت قربانى: }
$$

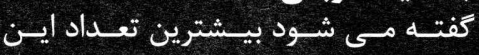
قربانيان را دختران خورد سال تشكيل داده و ميزان آسيب بذيرى آن ها نسبت به بـ بـسران. بيشتر بوده است. درزارارشى تحقيقى كه كميسيون مستقل

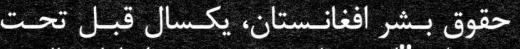

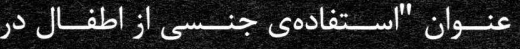




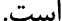

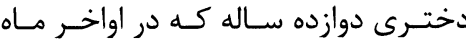

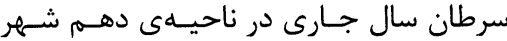

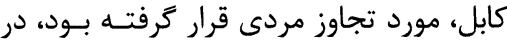

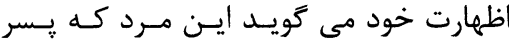

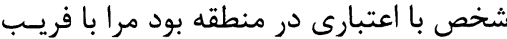

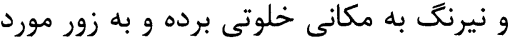

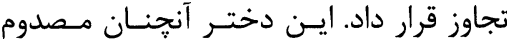

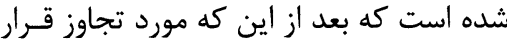

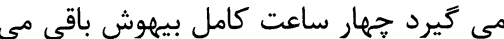

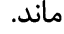

كودك هشت سـاله كـهـ يكـسال قبــل در

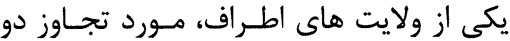

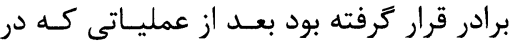

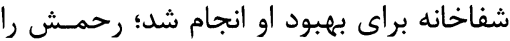

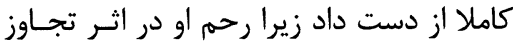

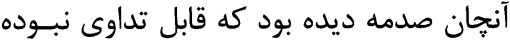

كودكى شش سالهى ديخـــى در يكى از

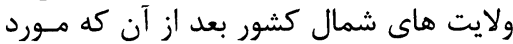

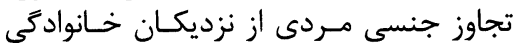

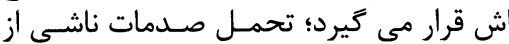
آن را نتوانسته، جان مير مي دهي دهد به همين ترتيب موارد زيادى اتفاق افتاده

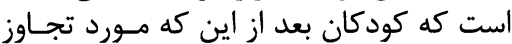

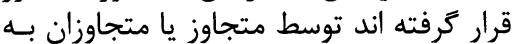
قتل رسانده شده اند.

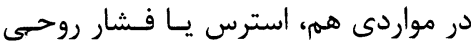

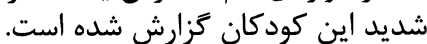

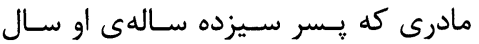

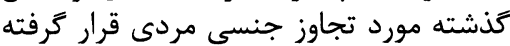

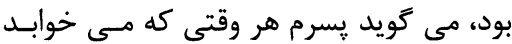
با وحشت و جيغ و ورئ فرياد از خواب بيدار شئ شده،

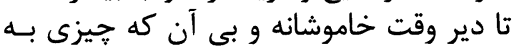
كسى بتويد مى خير ديد دخترى جهارده ساله كه قـبـلا در يكى از

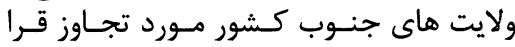

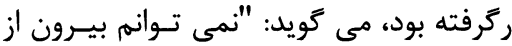

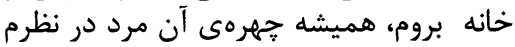

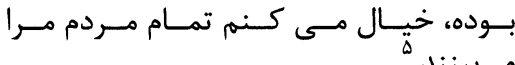

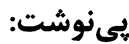

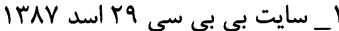

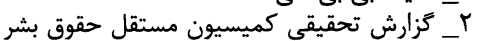

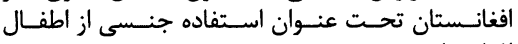
افغانستان

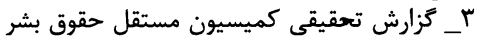

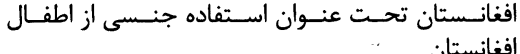

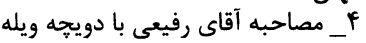

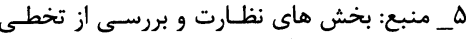

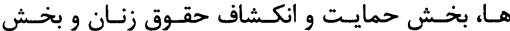

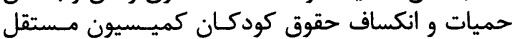
حقوق بشر افغانستان.
دستهى سوم بزرخسالان مريضند كـــ در

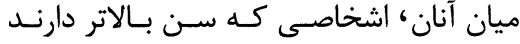

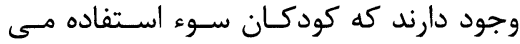

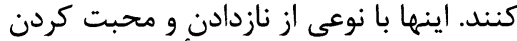

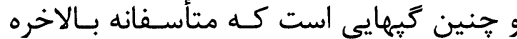

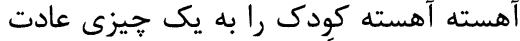

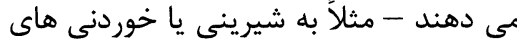

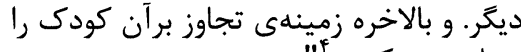
مساعد مى كنئد.

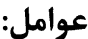

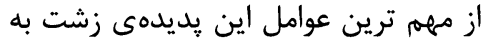

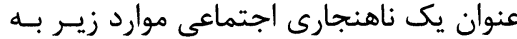

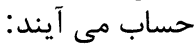

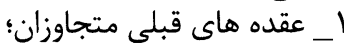

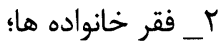

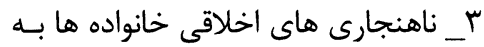
خصوص والدين؛

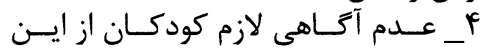
يديده و خطراتى ناشى از آن آن؛

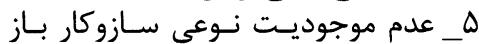

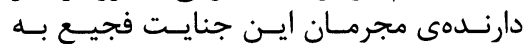

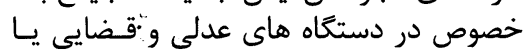
موجوديت نظام معافيت مجرمان دان

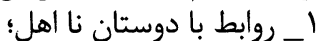

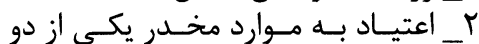
طرف متضرر يا متجاوز؛

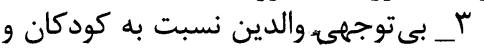

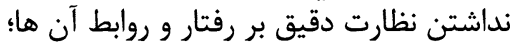

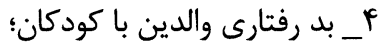

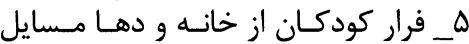

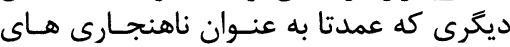

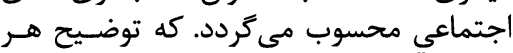

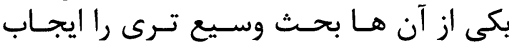
نموده و از حوصلهى اين نوشتهى لونى كوتا خـارج

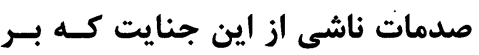
زيان ديدكان وارد شده و باقى مي ماند إند

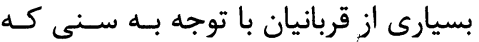

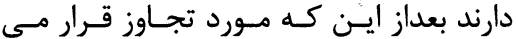

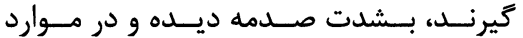

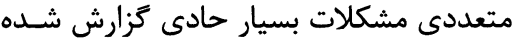

تعـدادى از ايـن كودكــان بـا جراحست يـا

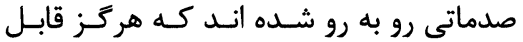

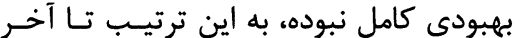

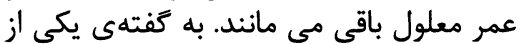

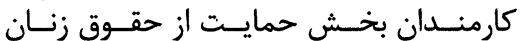

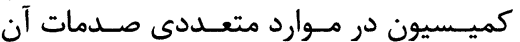

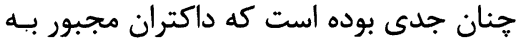

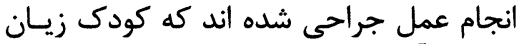

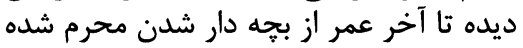

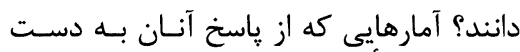

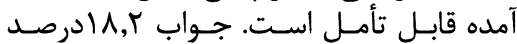

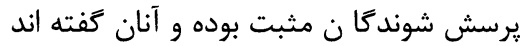

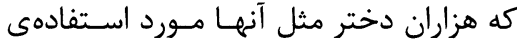

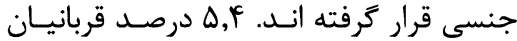

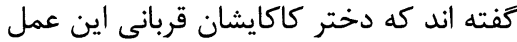

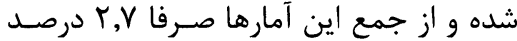

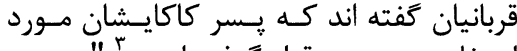

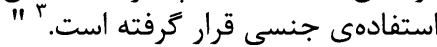

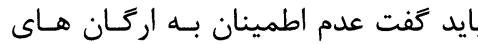

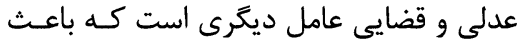

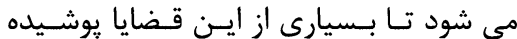

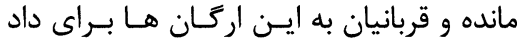

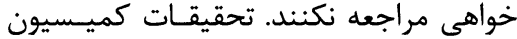
مطلب بسيار جالبى را نشان مي دهى دهد:

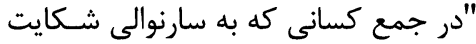

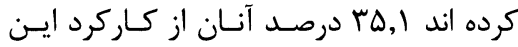

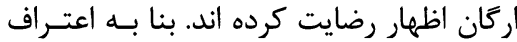

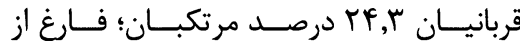

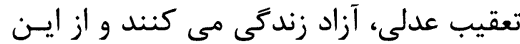

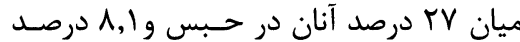

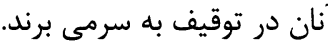

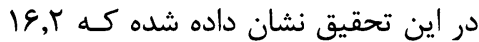

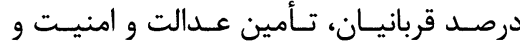

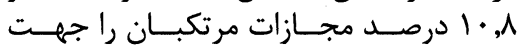

جلوگيرى ازاين يديده ي بيشنهاد كرده اند."

خصوصيات افراد متجاوز:

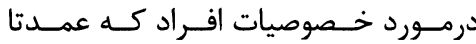

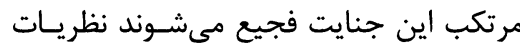

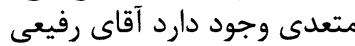

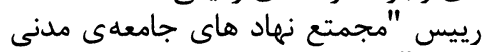

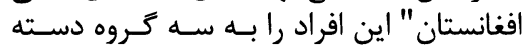

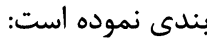
" برخى از اين تجاوزات جنسى است متأسـفانه

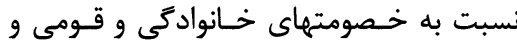
براساس عقده هاى كذشته و و سمتى اند. ايسن

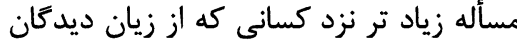

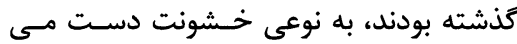

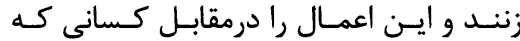

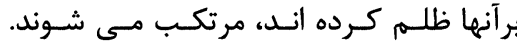

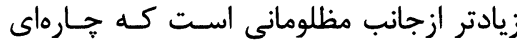

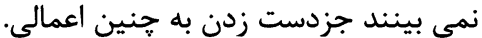

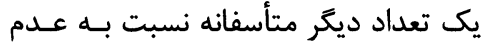

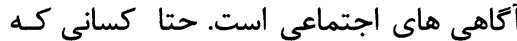

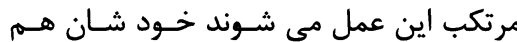

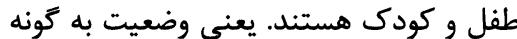

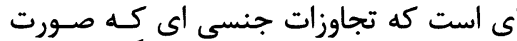

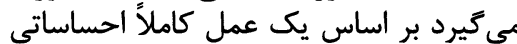

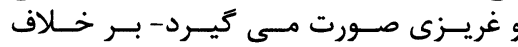

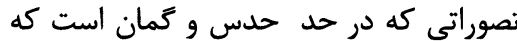

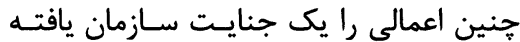

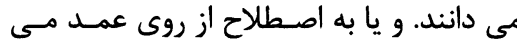

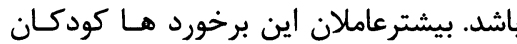




\section{قوباني شهوت بدر

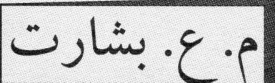

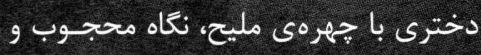

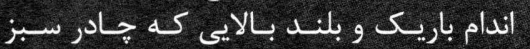

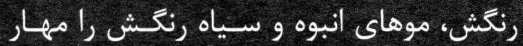

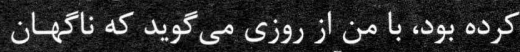

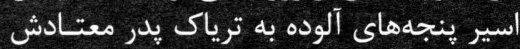

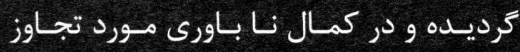
جنسى او قرار مى كيرد.

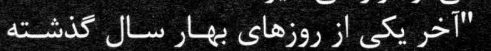

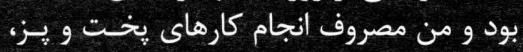

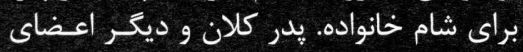

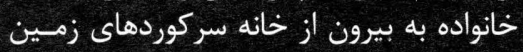

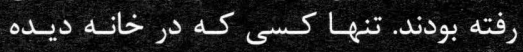

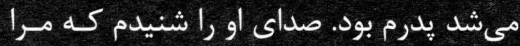

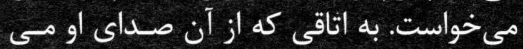

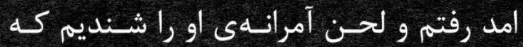
مى كفت زود جاى بياور هميشه ايـن طـورى الشع
به سر كورد هاى زمـين مبى بـرد، تـا غـماز

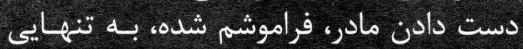

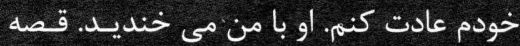
مى كفت. درد د دل مى كرد و و بازى مى كرد.

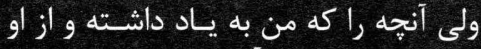

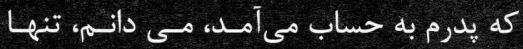
جيزهايى است كله بعد از بازگشت او او از ائران

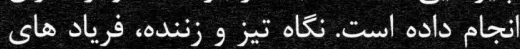

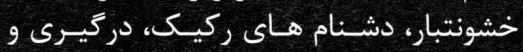

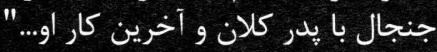

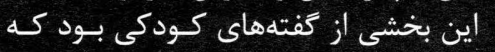

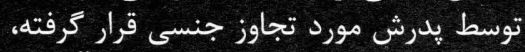

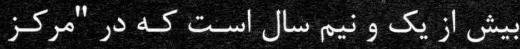

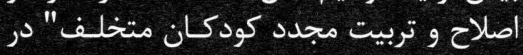

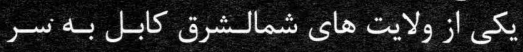

مى برد.
"ولـين بـار بعـا از بازكشتش از ائران.

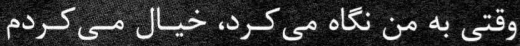

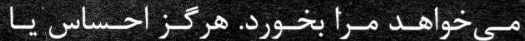
عاطفهى يدرى را در جشمان او نديدم. نغاه

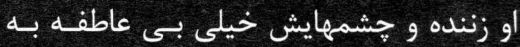
نظر مى رسيد. برخورد او با مـن بـ بـ كونسهاى

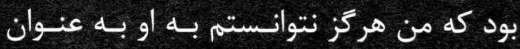

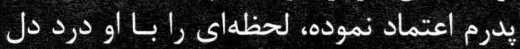

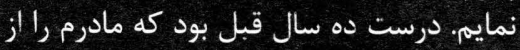

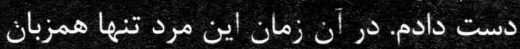

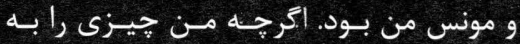
خاطر ندارم ولى به كفنتهى بدر كلانم او مـرد

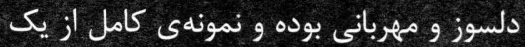

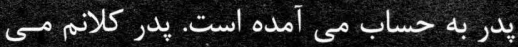

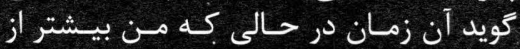
شش سال نداشتم او مرا در آغوشش كرفته و 
با تمام توانم دست و زا مىزدم تا خودم راز

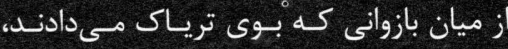

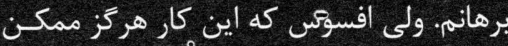

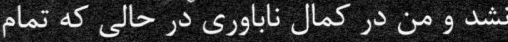

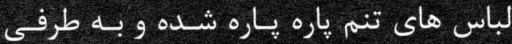

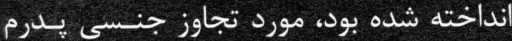
قرار كرفتم.

مردى با لبهاى دود زده و سـياه سـوخته،

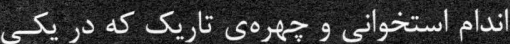
از اتاق هاى زندان ولايت ... بـهـ جـرم تجـاوز جنسى به دخترش اعتراف داشته و در حرى حبس

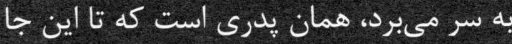

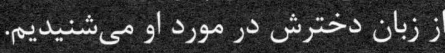

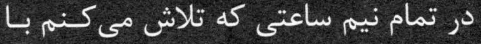
او سخن بكويم تنها دو جمله بر زبان او تكرار

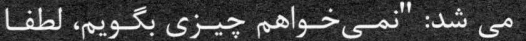
مزاحم من نشويدا" ماتي"

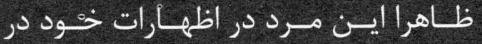
سارنوالى ولايت، به جرم خود اعتراف نمـوده، يروندهى قضايى او در ادارات عدلى و قضاتيى

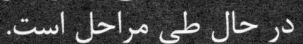

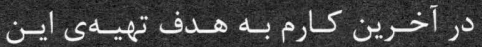

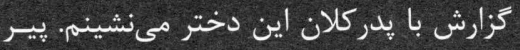

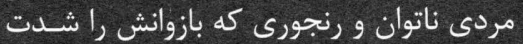

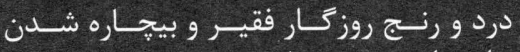

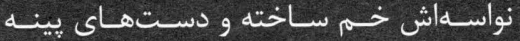
بستهاش هميشه مى لرزد بيان او خيلى كوتا و مختصر بود:

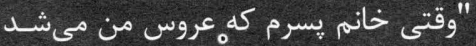

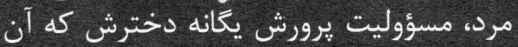

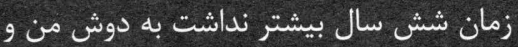

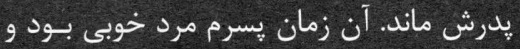

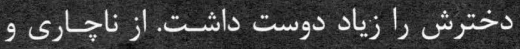

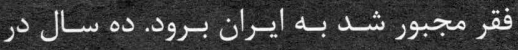

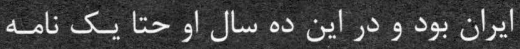

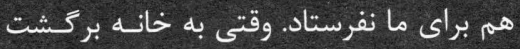

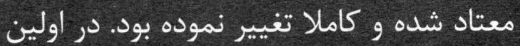
روز هاى بركشتش اسرار داشتت كـه بـ بـرايش زن بكيرم ولى اين كار از توان من بيرون بود.

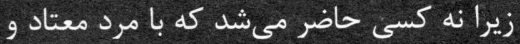

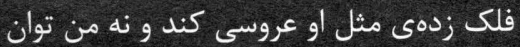

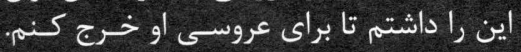

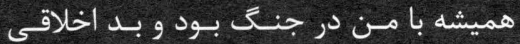
مى هرد. تا اين كه يك روز وقتى از سر زمين

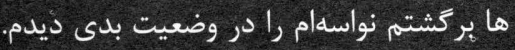

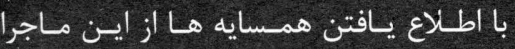

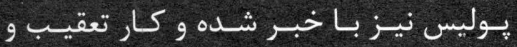

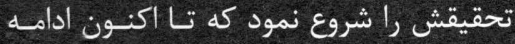
".
بود. اكر كارى كل مي خواست نمى توانستم به

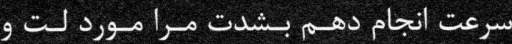

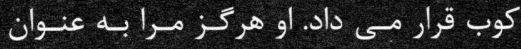
دخترش صدا ننموده و هميشه با دشنامهـاى هر

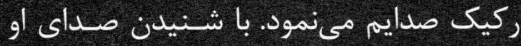

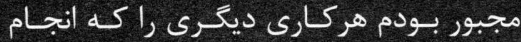

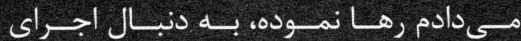

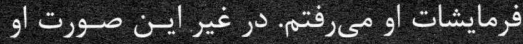

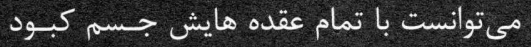

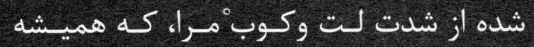
توسط او صورت مى كرفت دو باره زير مـشت كـ

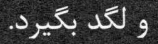
جاى را كه آماده نموده بودم بـه اط باقش

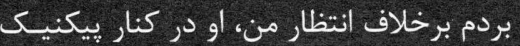

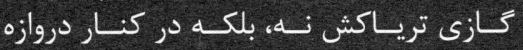

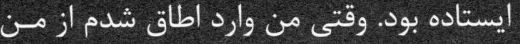

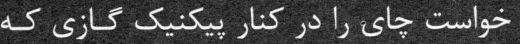

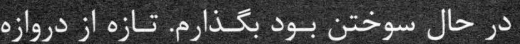

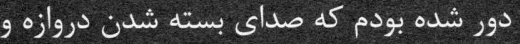

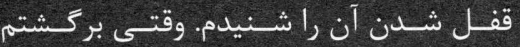

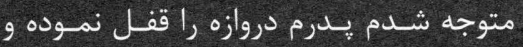

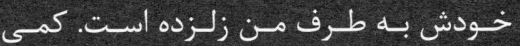

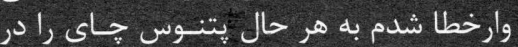

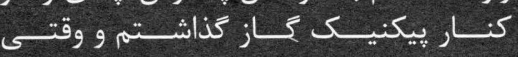

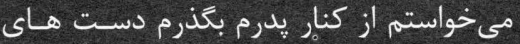

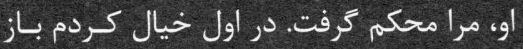

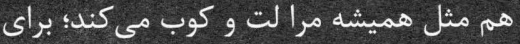

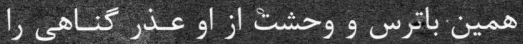
كه انجام نداده بودم خواسته، و تلاثى نمـودم

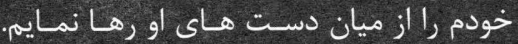
اليبر جان لطفا مرا نزينا ديكر زود تر از اين

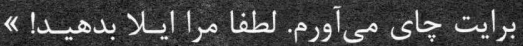

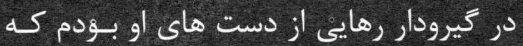

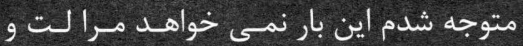

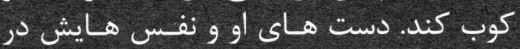

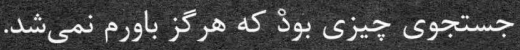

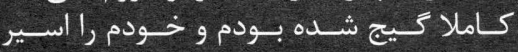

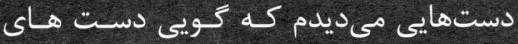

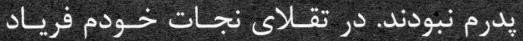

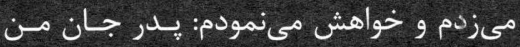

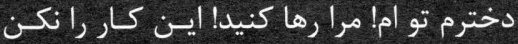

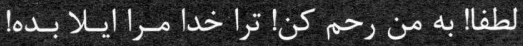

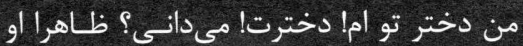

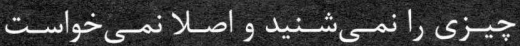

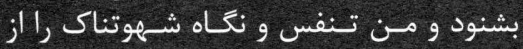

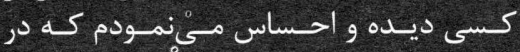

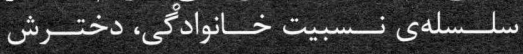
محسوب مى شدم. مان.

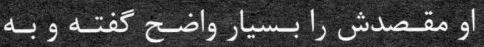

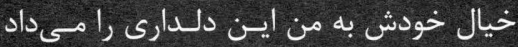

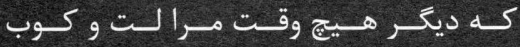
نخواهد كرد د. ن 


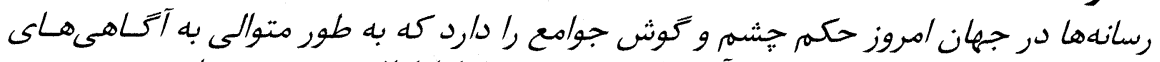

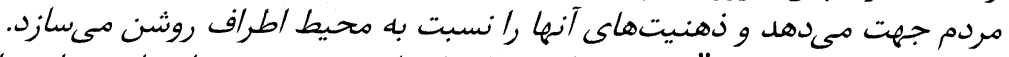

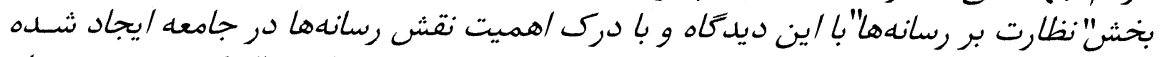

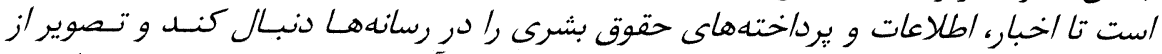

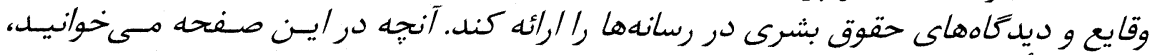

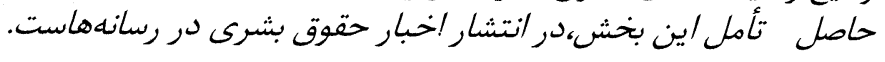

\section{از ميان خبر ها}

ســيد محمــد سـامع، رئسيس كميـسيون مستقل حقوق بشر در شمال مى كويد: "براى

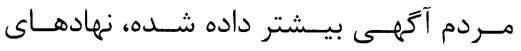

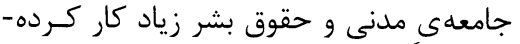

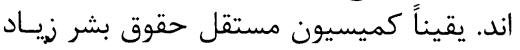

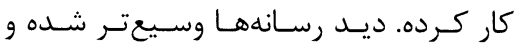

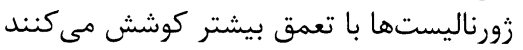

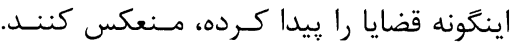

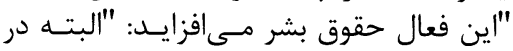

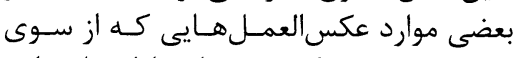

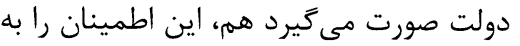

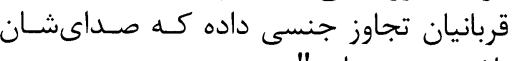

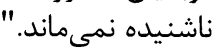

افزايش خودسوزى ها در هرات 9 سنبله آزانس خبرى يزواى

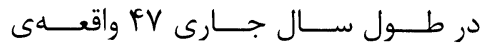

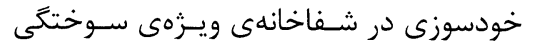

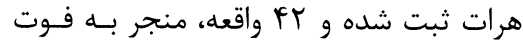

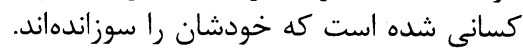

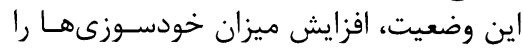

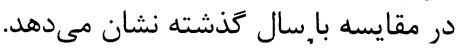

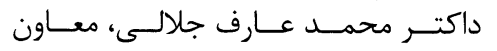

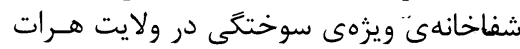

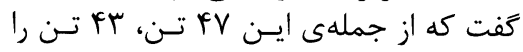

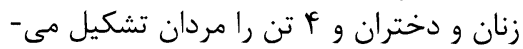

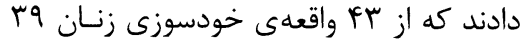

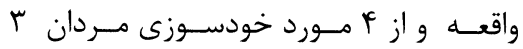

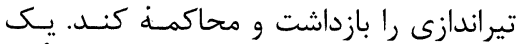
مقام يليس در كابل، وقوع أين حادثه را تأئيد

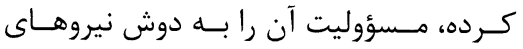
خارجى كذاشته است.

دادخواهى قربّانيان تجاوز جنسى

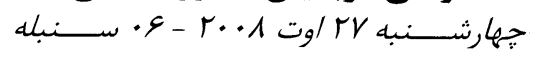
Irav

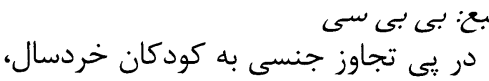

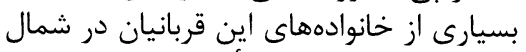

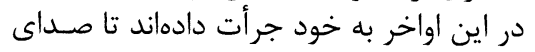

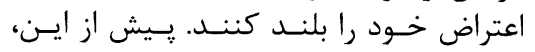

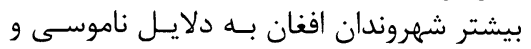

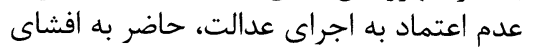

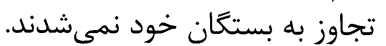

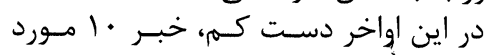
تجاوز جنسى به كودكان در شمال افغانستان إنان

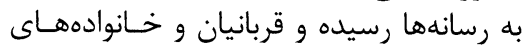

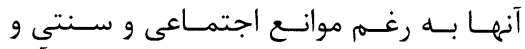

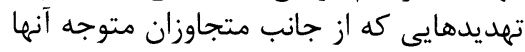

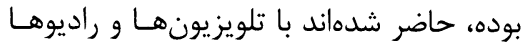
در اين مورد مصاحبه كنند.

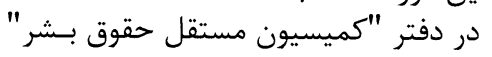

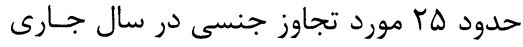
ميلادى ثبت شده است.

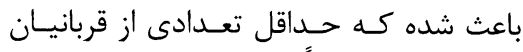

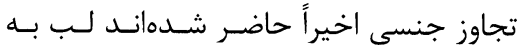
انتقاد از اين بدرفتارى اجتماعى بخشايند؟ لخد
'جهمهـار غيرنظــامى 'در شــــ كابـل كشته شدند

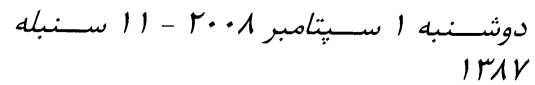

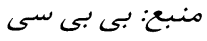

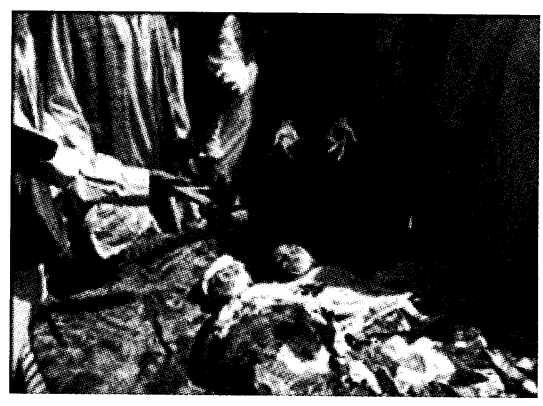

ساكنان منطقهاى در شرق كابل ادعا مى -

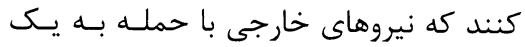

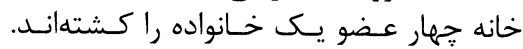

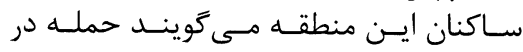

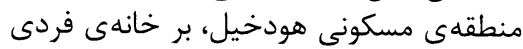

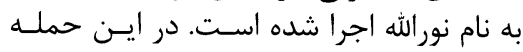

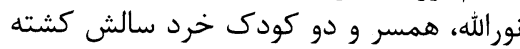

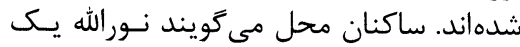

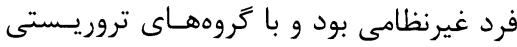
هيج ارتباطى نداشت.

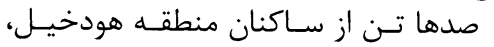

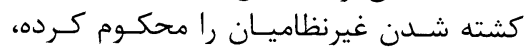

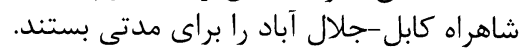

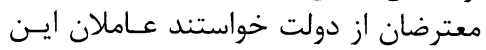




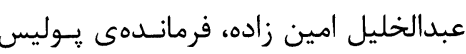

ولايت جوزجان بريده شدن زبان يكان فيك كـودى

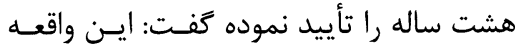

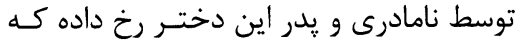

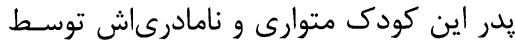
نيروهاى يوليس دستخير شده است.

\section{سوزانده شدن صد هزار جلد كتــاب} درسى جديد معارف

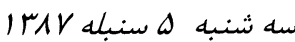
منبع: روزنامه راه نجات سنات

يك صد هزار جلد كتاب درسى جند جديد كه

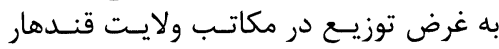

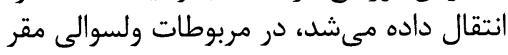

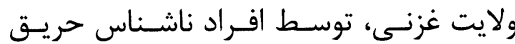

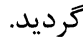

در اعلاميهى خبرى وزارت معـارف آمـدهد

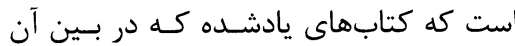

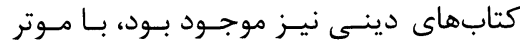

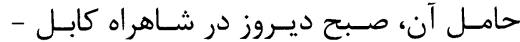
قندهار حريق گرديده است.

اين وزارت در اعلاميهى يادشده، از نيروهـاى إن إست

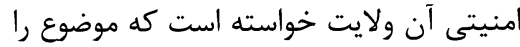
تعقيب و عاملان آن را مجازات كنند.

مرتى دهـــا غيرنظــامى در'حملـهـى نيروهاى آمريكايى

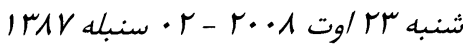

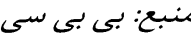

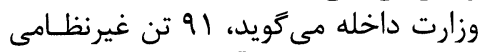

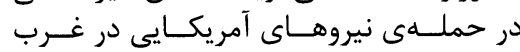

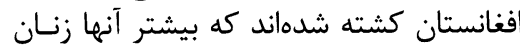

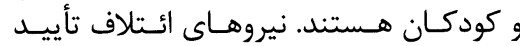

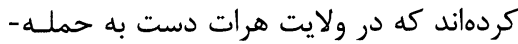

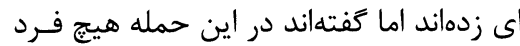
غيرنظامى كشته نشده است

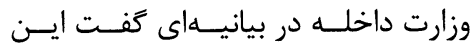

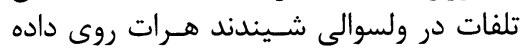

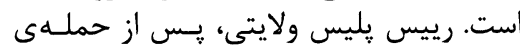

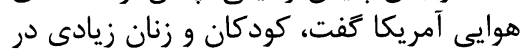

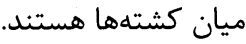

خود را براى اين كه مورد تجاوز جنسى قـرار

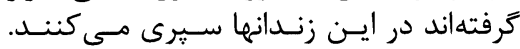

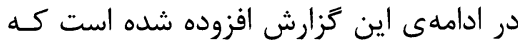

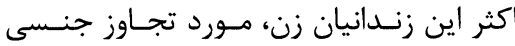

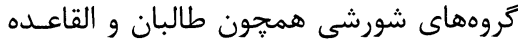

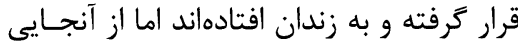

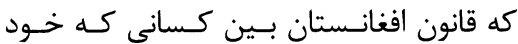
خواسته تن به روابط نامشروع داده و وكسان كسانى

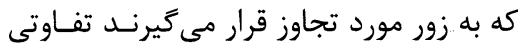

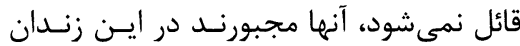

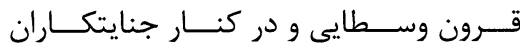

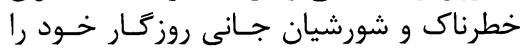

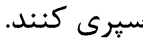

هاجد درصد از عروسها در كشور، زير هيجده سال سن دارند

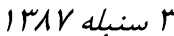
منبع: خبركذارى صداى افنغان

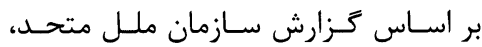

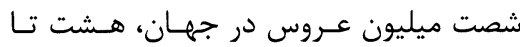

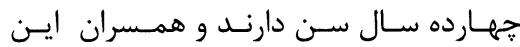
عروسهاى كم سن و سأل نيز اغلـ هـ مـردان

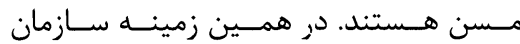

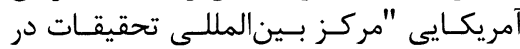

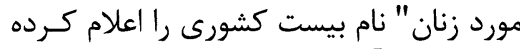

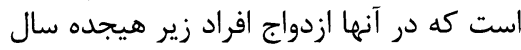

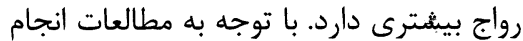

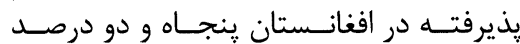

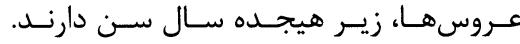

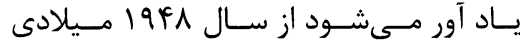

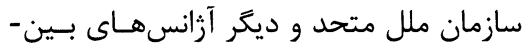

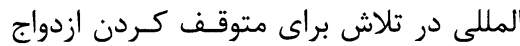
افراد زير هيجده سال هستند.

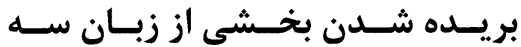 كودك، توسط والدين آنها

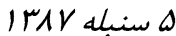 منبع : خبركذارى صداى افغ انغان}

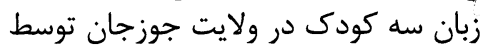

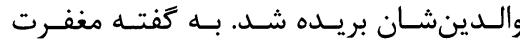

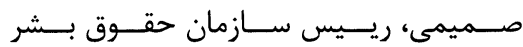

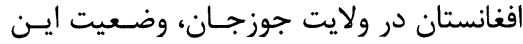

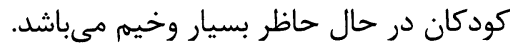

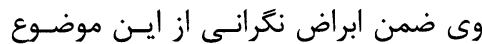

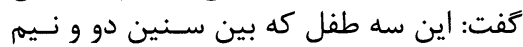

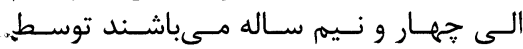

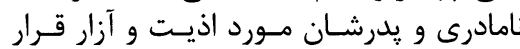

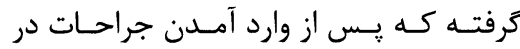

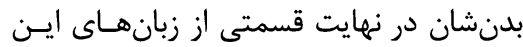

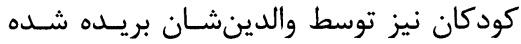

واقعهى آن منجر به مرى شده است.

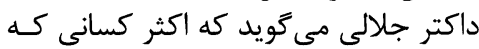

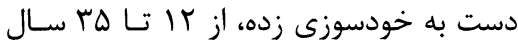

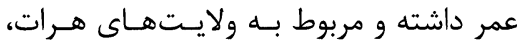

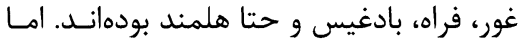

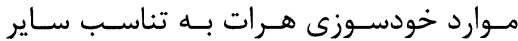
ولايتها، بيشتر بوده است هـر است

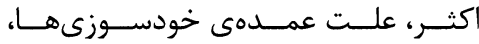

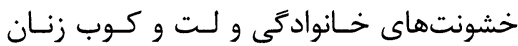

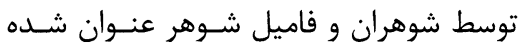

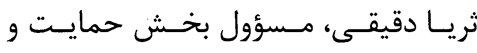

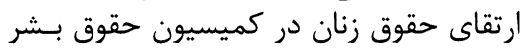

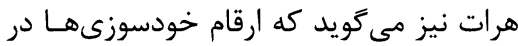
شهرها كم ولى در روستاها زياد است.

\section{تلفات ملكــى در حملـهـى انتحـــارى ولايت بادغيس ملفي سنبه r سنبله بادغيس} منبع: آزازنس خبرى ريله روز

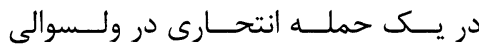
غورماج ولايت بادغيس 9 تن از افـراد ملكى ولى كشته و زخمى شداهي شاند.

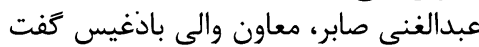

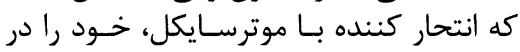

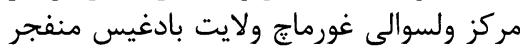

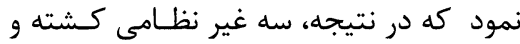

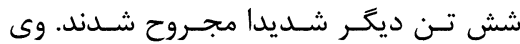

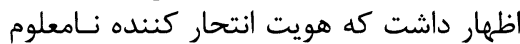

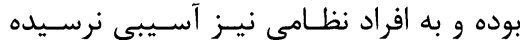

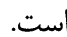

در همين حال ملا جمال الدين، يك تن از

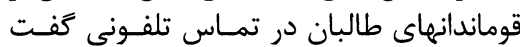

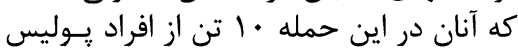

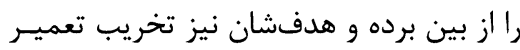
ولسوالى غورماج بوده است.

زندانيان زن قربانيان تجاوز جنسى

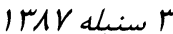

$$
\text { منبع: خبركذارى صداى افغان }
$$

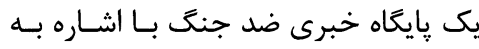

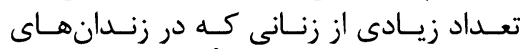

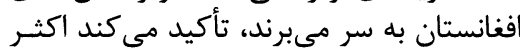

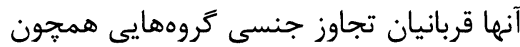

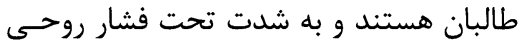

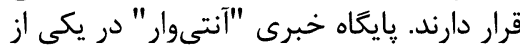

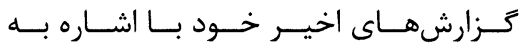

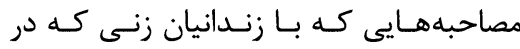

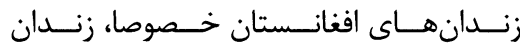

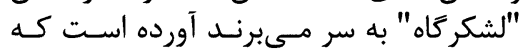
اكثر اين زندانيان در حدود · ب سـال از عمـر 


\section{هـلح}
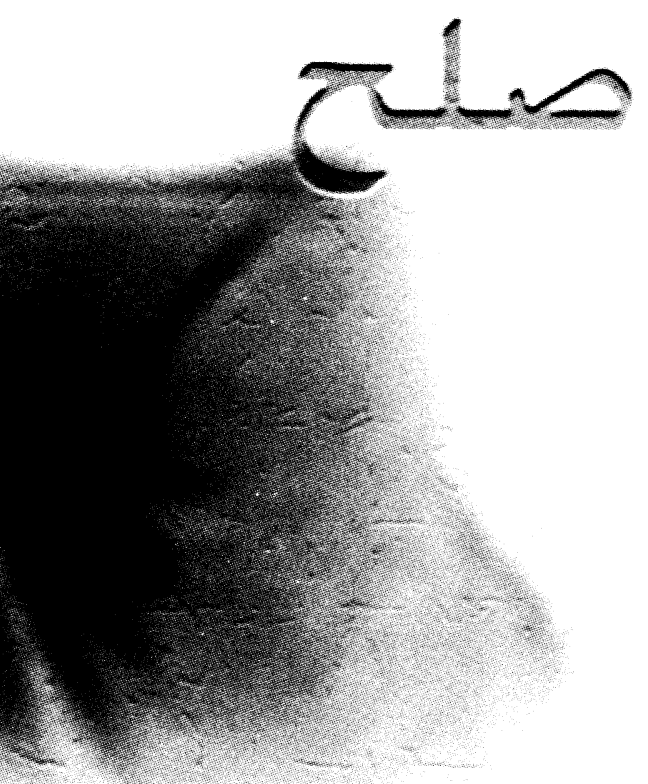

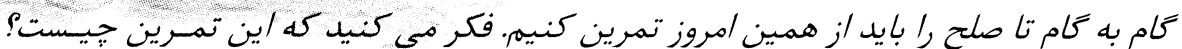

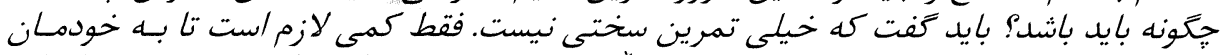

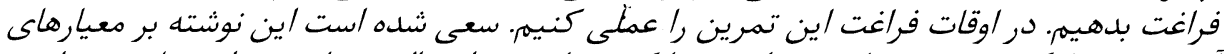

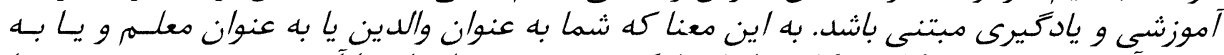

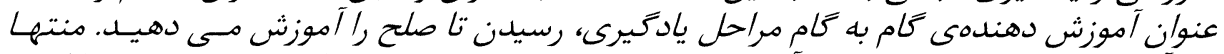

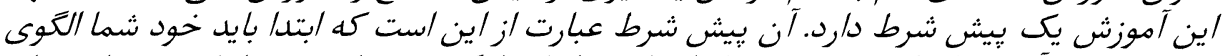

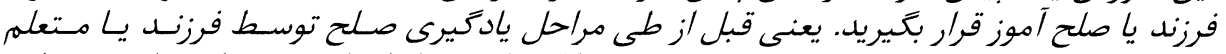

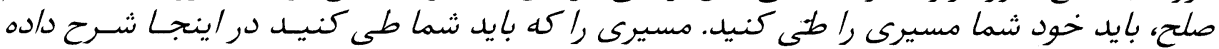
شله /ست. اكنون بلون هيج سخن ديكرى به سراغ شرح و تفصيل قدم به قدم قلدم تا صلح مى رويم.

نطق مى كنيد. البته كه يادداشـت هريـك از إز

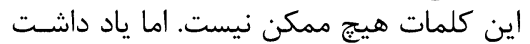

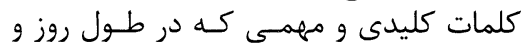

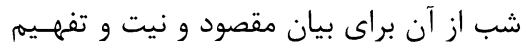

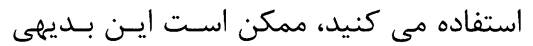

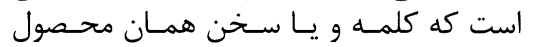

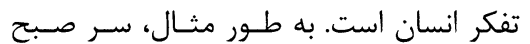

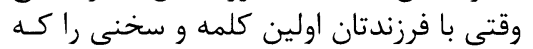

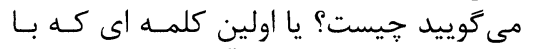

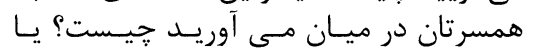

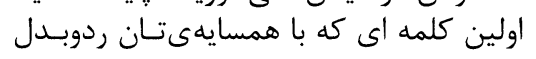

$$
\text { مى كنى خيست؟ }
$$

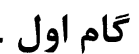

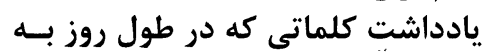

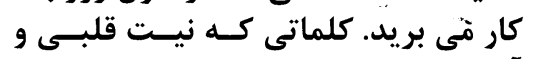

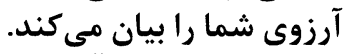

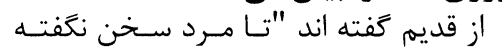

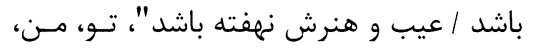

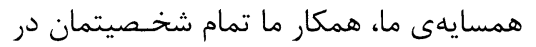

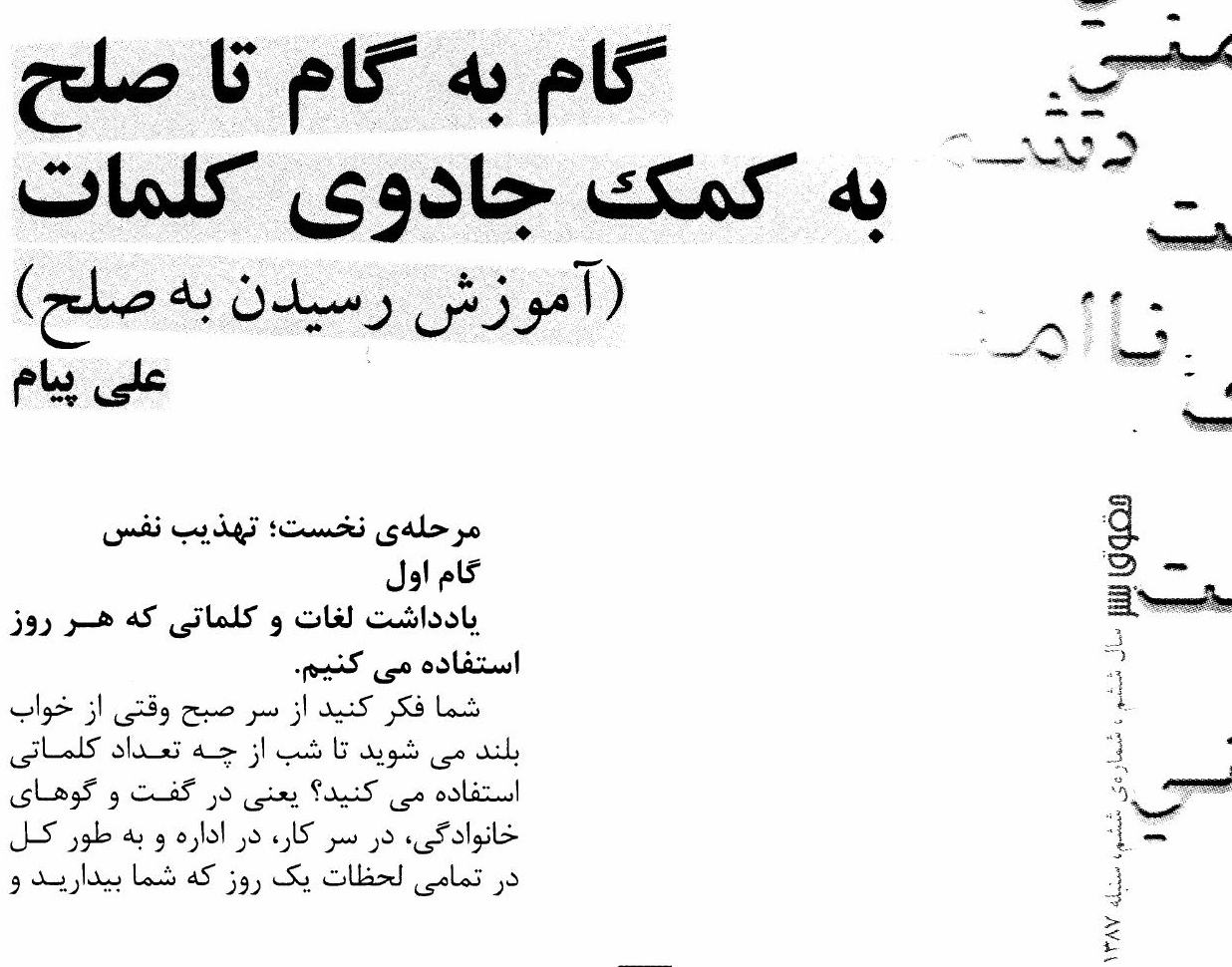

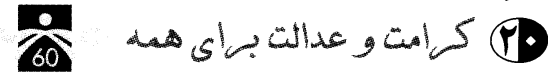




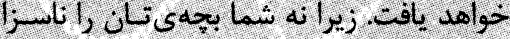
خواهيد كفت و نه زنتان رأ و نـه هموطنتان

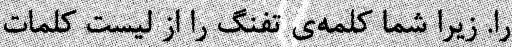

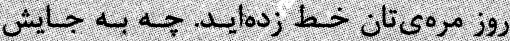

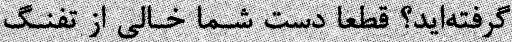

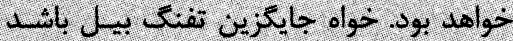
يا كتاب يا قرأن شريف، يا هر وسيلهالى ديكر

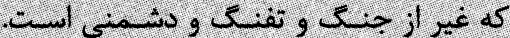

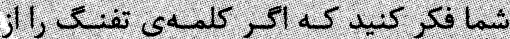

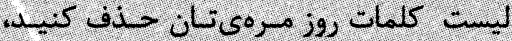

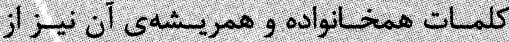
فرهنك زندكيتان حذف خواهد شد. وقنتى كاند

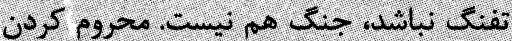

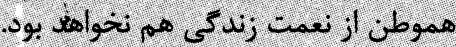

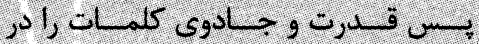
زندكيتان درك كنيد. به طور نمونه اكر أمروز

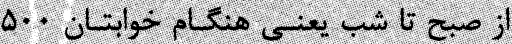

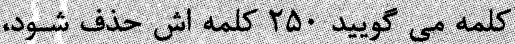

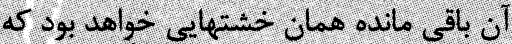

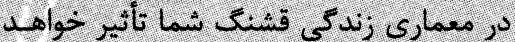

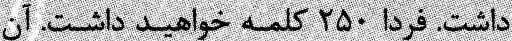

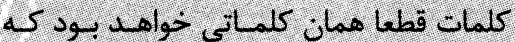
شما خوشتان مي أيد. مثلا. كمك بك به ديكرى. صلح، كذشت، نيكى، زندكى مـسالمت أميز؛

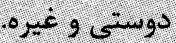

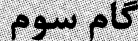

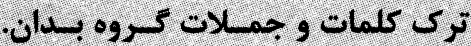

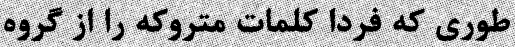
كلماتى كل به كار مي بريد حذف كات كنيد.

\section{كام جهارم: آبينكى خويشتن}

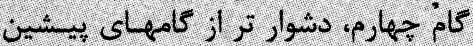

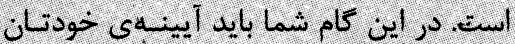

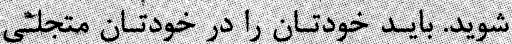

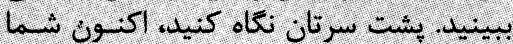

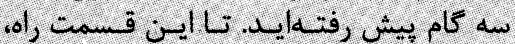
لغات و كلماتى كه هر روز استفاده مي كرديد

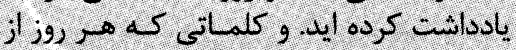

لامذهبا يا عبارات ديكر و بدتان بيايد، أنها أ ادر سنون بالن بنويسيد

تتيجهاى اخلاقى قضيه:

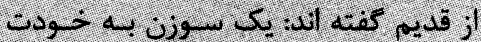

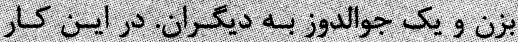

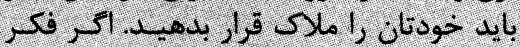
مى كنيد كل جنك ويرانكر است و فرزنستان

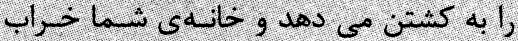

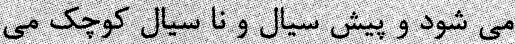

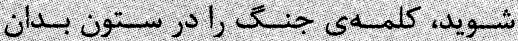

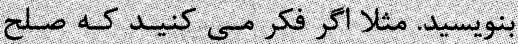

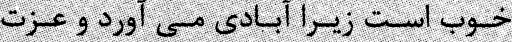
مى أفريند و يا ايثار، كنشت، همكارى كردين

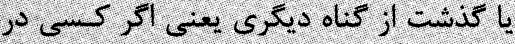

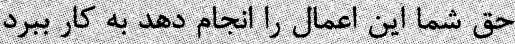
يا از آن كلمات خوش مى شـويد، در سـتون

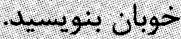

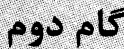

تمام كلماتى كه يادداشت كروند إيـد، در دو ستون بدان و خوبان بنويسيد. اين

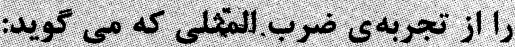

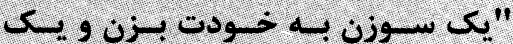
جوالدوز به ديكران." تحرير كنيد.

\section{تمام سوم تمريت ترك كلمات بدات} مرحلهى سوم، مرحلهى دشوارترى استيت

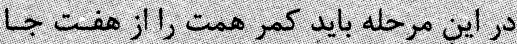

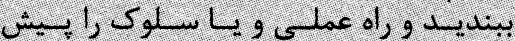

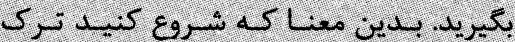
كلماتى را كه در كروه بدان است. با قلم سرخ

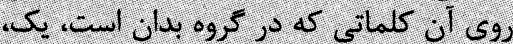

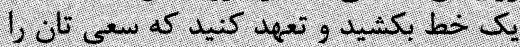

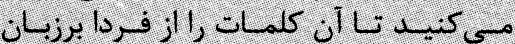

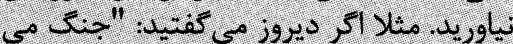

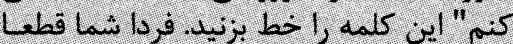

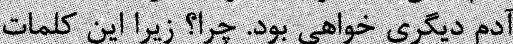

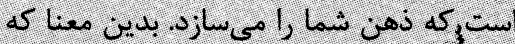

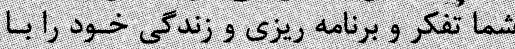

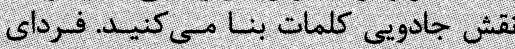

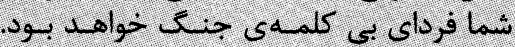

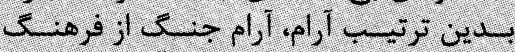
زندكى شما حذف خواهد شد. آيا جه جيهز

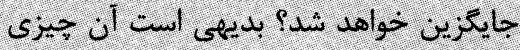

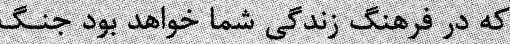

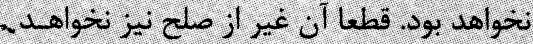

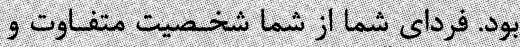

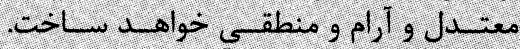

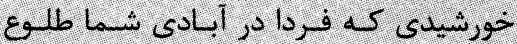

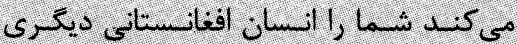

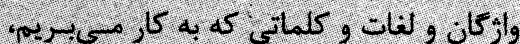

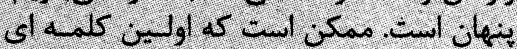

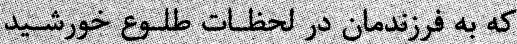

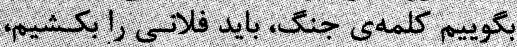

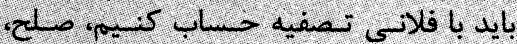

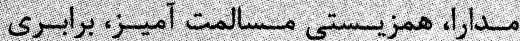

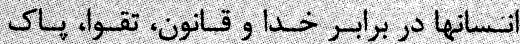

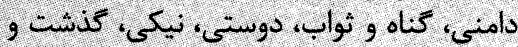

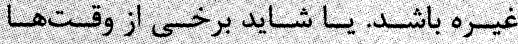

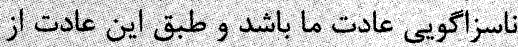

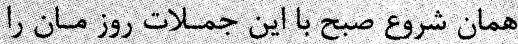

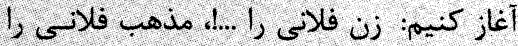

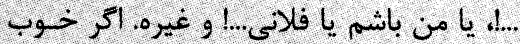

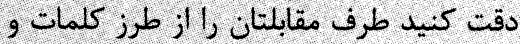

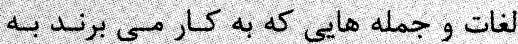

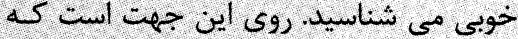
در اولين كام تا صلح، كلماتى راكي اكه در طبول

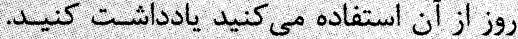

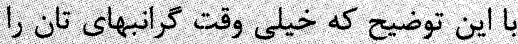
نخواهد كرفت: اكر لحظاتى رابه بايه ايـن برناميه

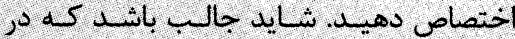

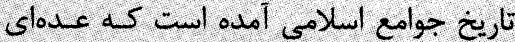

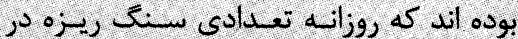

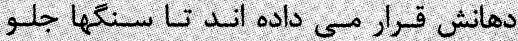

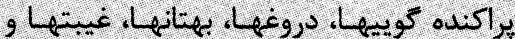

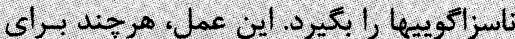

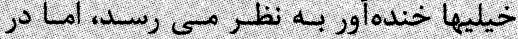
حقيقت حكايت از برنامه ريزى جالبي دارد.

كام دوم نيك و بد كردن كلمات كام بعدى اين است كد كل كلمات و و جمله هات

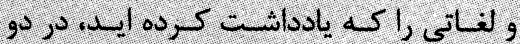
ستون قرار دهيد. جدول نيك و بد كردن كلمات

\begin{tabular}{|c|c|c|}
\hline بدان & خوبان & شماره \\
\hline جنك & صلح & 1 \\
\hline بنده خدا & بربحت & Y \\
\hline بعضى برى بر & برابرى خدا أدمى قانون & $r$ \\
\hline
\end{tabular}

مر اين كام، شما به عنوان بلدر و شـما بـ به عنوان مادر كه سكان رهبرى خانه و و جامعـه

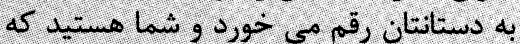

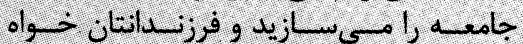
خشتهاى خام بناى جامعه خواهد بـود خـواه

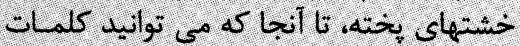
را در دو ستون بنويسيد و خوب و و بـ كيد كنيد

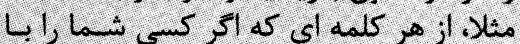

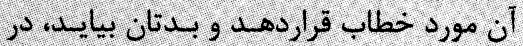
ستون بدان بنويسيد. به طور مثال. اكر كسي كي

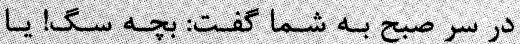


حساب بيايند كـه درس آم-وزش صـلح رادر

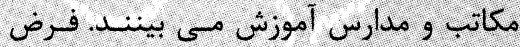
كنيد فرزند شما سر صنف نشسته است، حارئ حالا

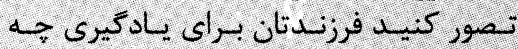

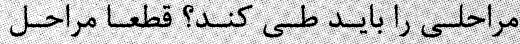
يادكيرى يك سلسله معيارهاى علمي است

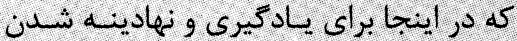
فرهنى صلح از آن بهره مى كيريم.

مراحل يادتيرى مفهوم صلح ويـرنى كود5ان

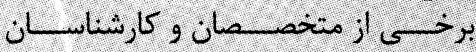

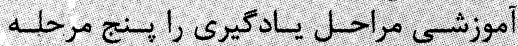

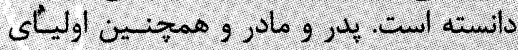

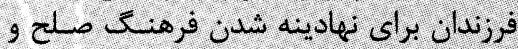
رسوخ آن در ذهن وقلب فرزندان مسي توانيند از قاعده و الكوى يادكيرى استفاده كنيند. بـه

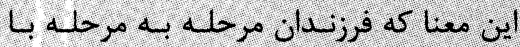

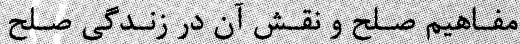
جويانه و صلح آميز افنانستانى آشنا مى شوند

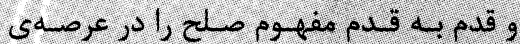

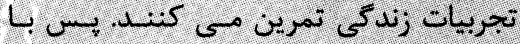

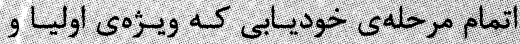
والدين مى باشد، نوبت به تربيت و وفرهن سازى صلح در حيات فرهنى سازى فرزندان مى رسد. البند، اين الكو مى تواند در نصاب

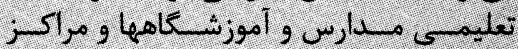
تعليمى نيز كاربرد داشته باشد و مفيد واقيح

مرحلهى اول: ادراك مفزوم ملك

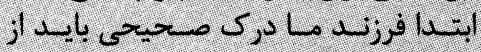
مفهوم صلح و.زشتى جنك دراشته بائد. براى رسيدن به اين مرحله جه بايد كرد؟؟ بـه نظبر

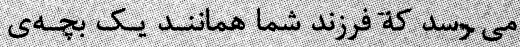
مكتبى بايد مضامين صلح، جمله ها، سمروده

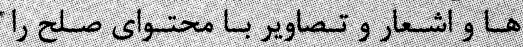
مطالعه و مرور كند. در اين مرحله مى توانيم ماريم به كمك وسايل كمك آموزشى مانتد تصاوير

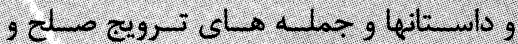

راهنماياني كه فرزندان و دانش آموزانتان شما

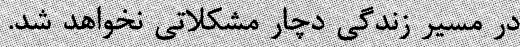

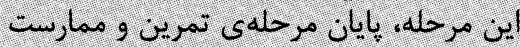
فردى شماست. تا اين مرحله شما فقط سير سير

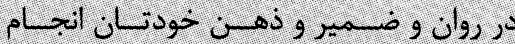

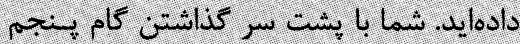

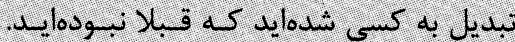
منتها اين سفر نه جندان دور و صعب العبسور

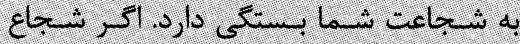

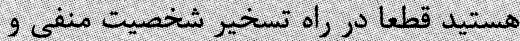

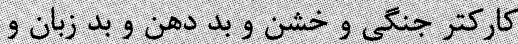

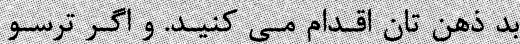
هستيد همجنان برده و نوكر و غلام كلمات و ونات

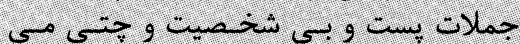

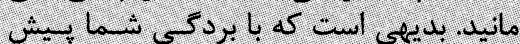

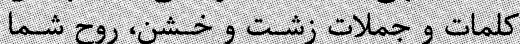

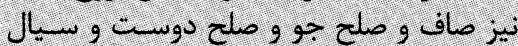

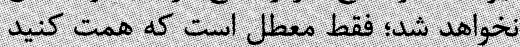

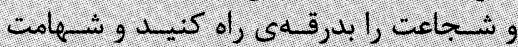
شكستن شخصيت زشت و شيطانى و وجنت

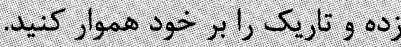

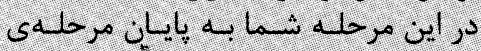
نخست قرار كرفته ايد. در ايسن مز حلـه شـان

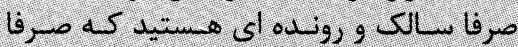

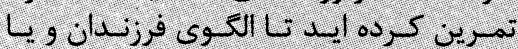
دانش أموزانتان قرار بكيريد. هايان مرحلدى ن

\section{دام بنجم}

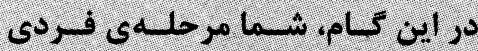

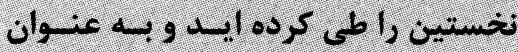
الكو و يا لوحه قرار مي كيريد.

\section{مرحلهى دوم: تهذيب غير}

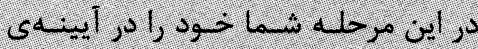

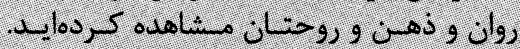

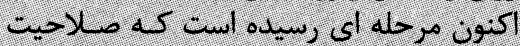

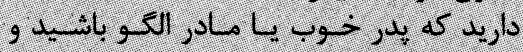

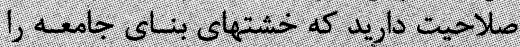

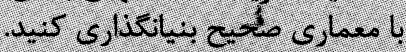

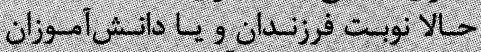
شماست. نصور كنيد كة آنان خشتهائ بنساى

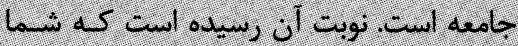

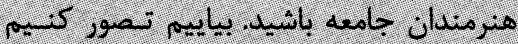

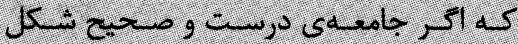

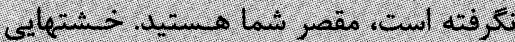

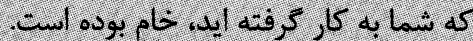

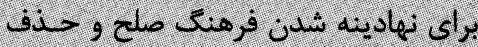

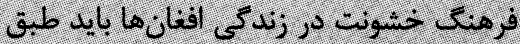
كنيم. جامعه با به عبارت ديكر فرزئندان شما و و مين

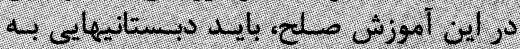

بيدار شدن تا وقت خواب بـا آن سميرى ميى كردي

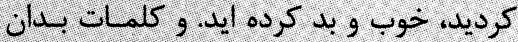

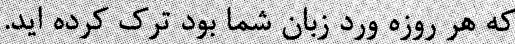

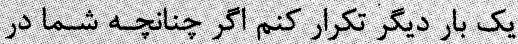

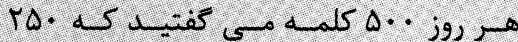

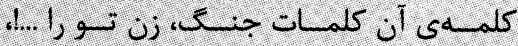

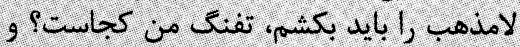

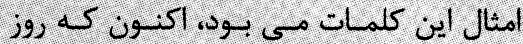

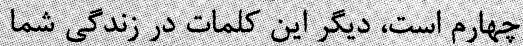

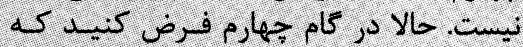
آيينه مستيد. أيينه اي كم روى دي ديوار خانهى

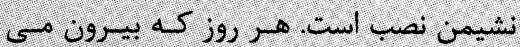
رويد، در برابرش مى ايستيد و تمام قد خـون

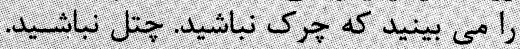
موى سر شما شائه باشد. كفش ون و كالائ شما

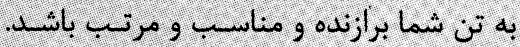
فرض كنيد كه اين آيينه، شما هستيد. اينك

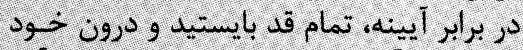

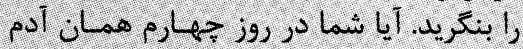

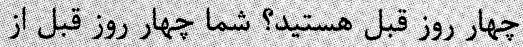

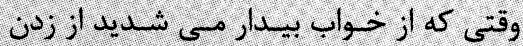

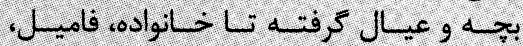

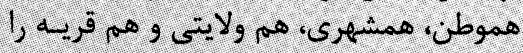

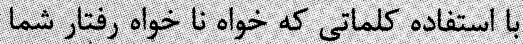
را سوق مى داد مورد حمله قرار مسي داديديد.

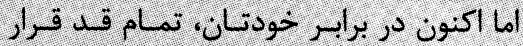

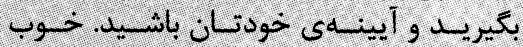
بيينيد كه جقدر متفاوت شدمايد.

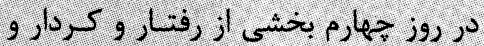

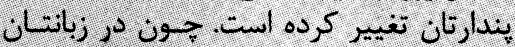

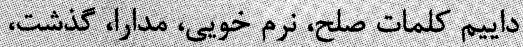

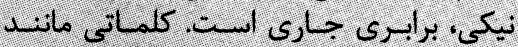

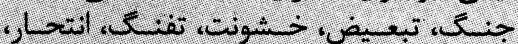

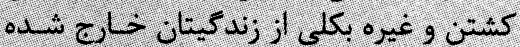
است. در اين كام، شما خودثان رانسان السان نيك

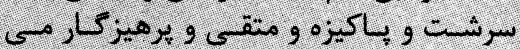

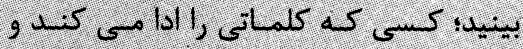
رفتارى از وى سر مى زند كي كاملانلا بر ميدار

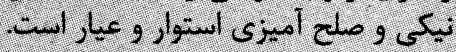

\section{كام جمهارم}

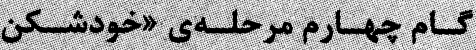

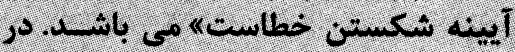

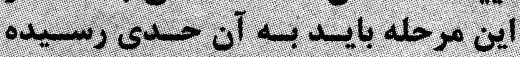

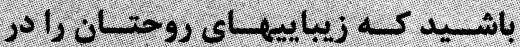
خودتان مشاهده كنيد.

Liol,

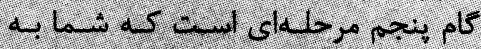

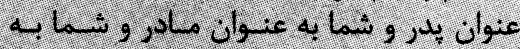

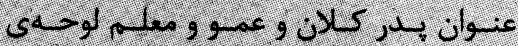
رامنماي فرزندانتان و داثش آموزانتان هيتيد. 


\section{نتيجه كيرى كنيد.}

:تيجحة

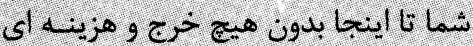

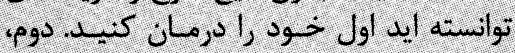
فرزندان نيكو سرشت و و باكى دامن ور و بان اخلاق

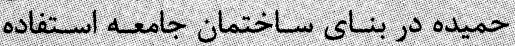

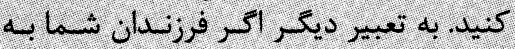
عنوان مصالح ساختمان و بناى اجتماع به إن ار

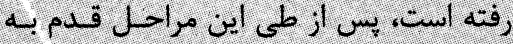
قدم به مراحل رفتار نيك، كردار نيك و ويندار نيك خواهند ربيد در بايان، ذكر اين نكته لازم است كه اين

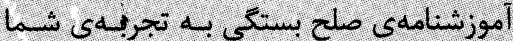

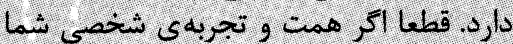

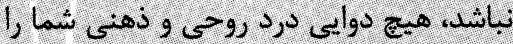
درمان نخواهد كرد. بس، بياييم براى يك بـ بار

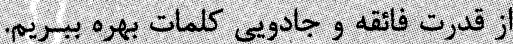
شايد دوايى باشد براى درمان ذهنهاي جنيك

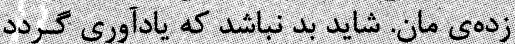
هيج قدرتى بالاتر از ذهن شما و ضمير شـانما

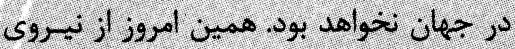
فائق و قدرتمند ذهن و ضمير و نيروى درونى

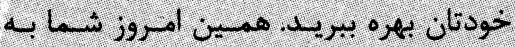
عنوان والدين كه مسؤول فرزندانتان مـتسيد

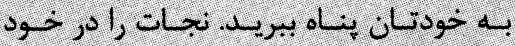
بجوييد. البته اكر مى توانيد ايـن أموزئ راني

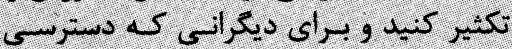

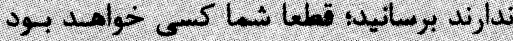

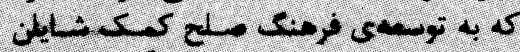

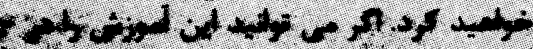

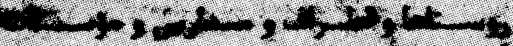

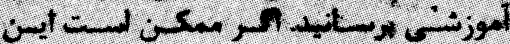

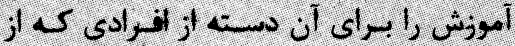

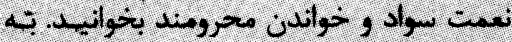

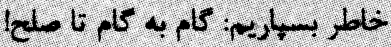

مر حلهى سوم: تسلط

در اين مرحله فرزندان شما به كاربرد كلمات و جملات مسلط مى شود. در اين

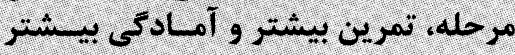
بايد صورت بعيرد.

مرحلهى جهارم: ارزيابى

مرحلهى جهارم، مرحلهى ارزيابى استيت. در اين مرحله شما بايد فرزندانتان را امتحسان وارزيابى كنيد. در اين مرحله مي في فيميد كيده

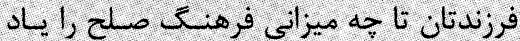

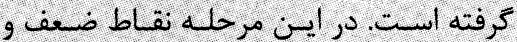

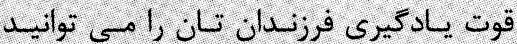

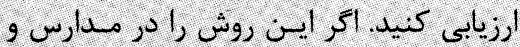

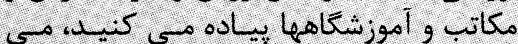

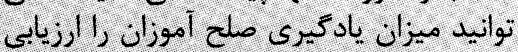

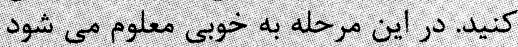

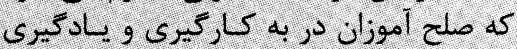

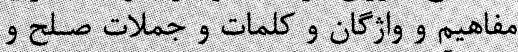
نقش آن در زندكى شان تأ جانه ميزانى موفنق بوده است

\section{مرحلهى جهارم:أرزيابى}

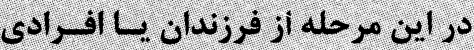

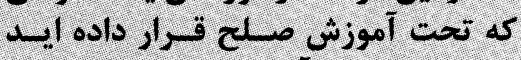
امتحان به عمل آوريد تا ميزان يادكيرى في فاده صلح مشيخص شود.

مرحلهى ينجم: جمعبندى

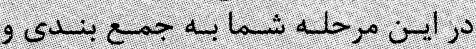

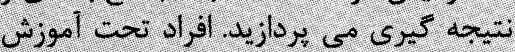

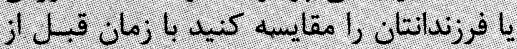
آموزش صلح. حتما با نتايج بالا و فوق العان فياده

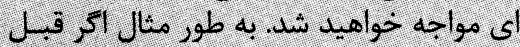

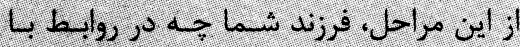

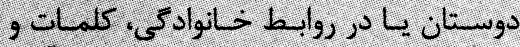
جملات و برخورد خشن و غير مسالمت ران أميز

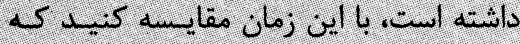

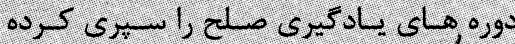

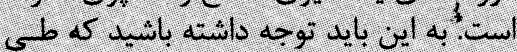
مراحل، يادكيرى صلح هيج خرج و و هزينه أى

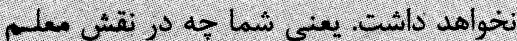

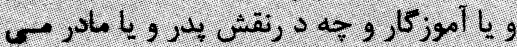

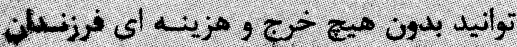

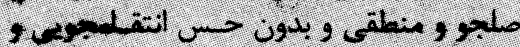
سرئار ال لملفت روع داشته باشيد.

مر حلهى بنجم: جمع بندى:

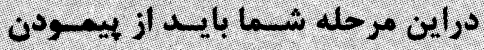

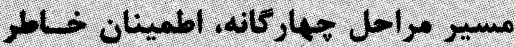
بيدا كنيد. يعنى از طى مراحل

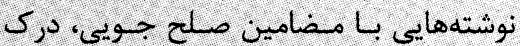

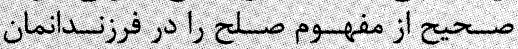
. 5 .

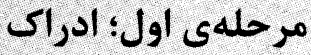

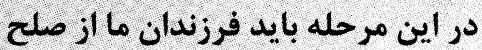
و فرهنَ صلح درك به صحيح برسد. مر حلهى دوم: تثبيت

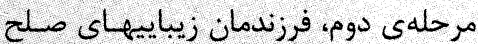
را درى كرده است اما به طو كامل نمى توني تواند

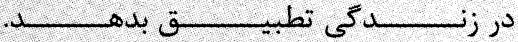

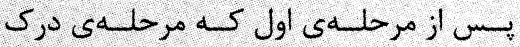

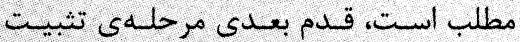

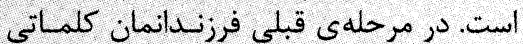
مانند صلح، كذشت، مدارا، لطف و ورئ برادرى يادي

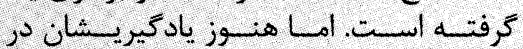

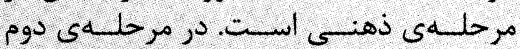
تمرين عملى مى رسد. اين مرحله درى دشوارتر

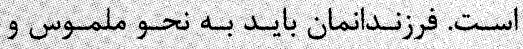

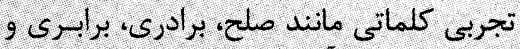

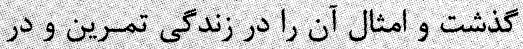
ذهن شان تثبيت كند تا اين كلمات وجمات تركات

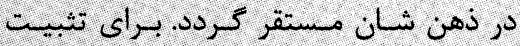

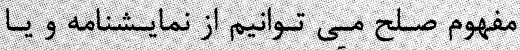
نقاشى و امثال آن استفاده كنيم.

\section{مرحلهى دوم؛ مرحلهى تثبيت}

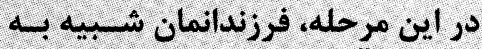

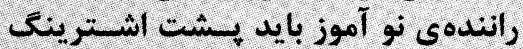

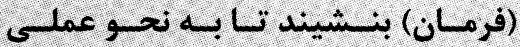
راندكَى در ذهنش تثبيت شود.

مرحلهى سوم: تسلط

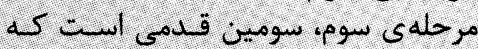

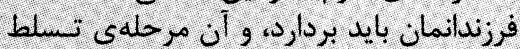

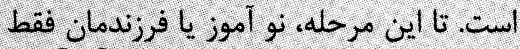

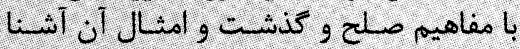

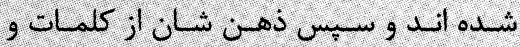

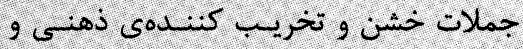

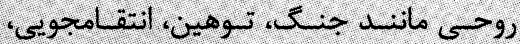

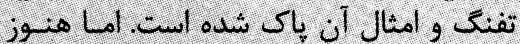
تسلط نيافته است كل ذهن و ورح و و روانشان

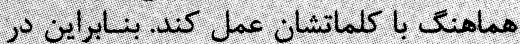

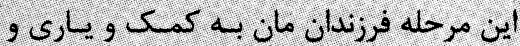
قدرت جادويى كلمات و وجمله هـان و و عبـارنات

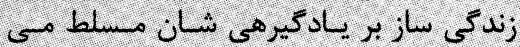

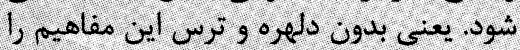

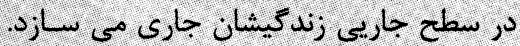

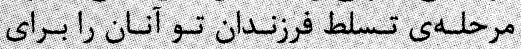
مرحلدى بعدى آماده خواهد كرد. 


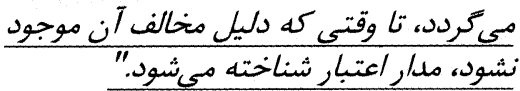

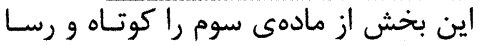

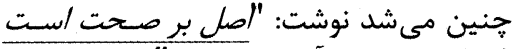
مخر /ينكه خلاف آن ثابت شود."

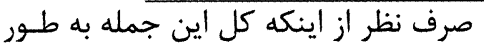

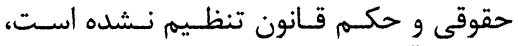

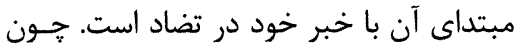

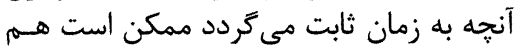

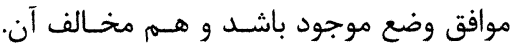

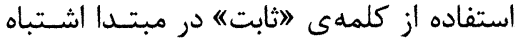

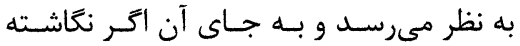

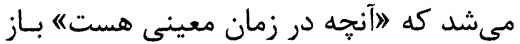

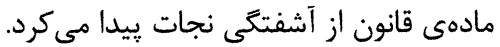

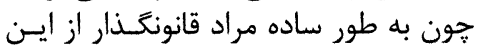

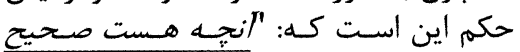

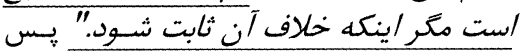

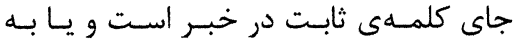

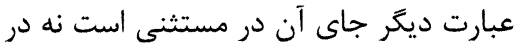
مستثنى عنه.

مادهى سوم-(r): "الغاى حكم قانون جـز

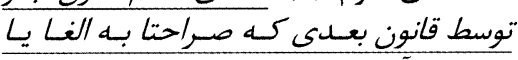

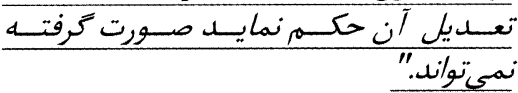
جيزى كـهـ در موقـع نتـارش ايسن قـانون

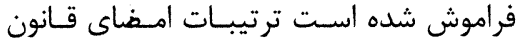

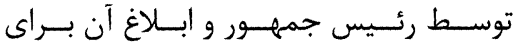

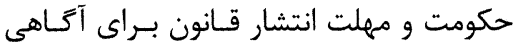

قانون وجود داشته باشد، اجتهاد جواز ندارد.

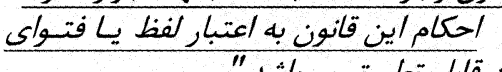
آن قابل تطبيق مى إشاشد."

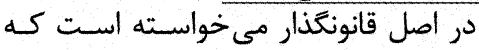
اين حكم را انشاء نمايد:

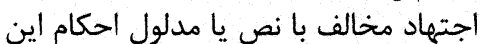

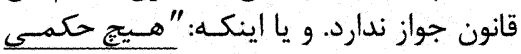
نميتواند مخالف نص يا مـدلول احكام ايسين قانون باشد."

ولى مي بينيم كه اولا ايجاز رعايست نسشده

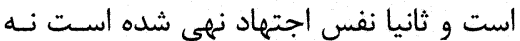

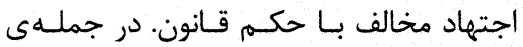

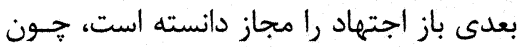

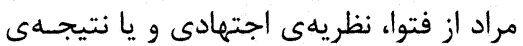

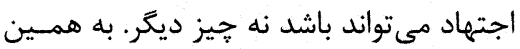

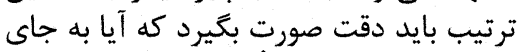

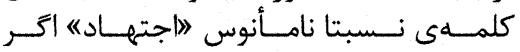

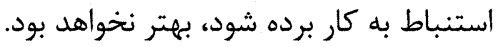

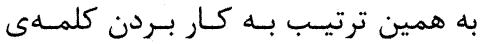

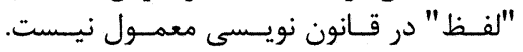

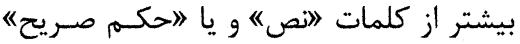

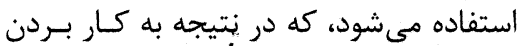

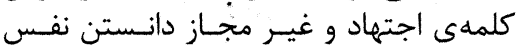

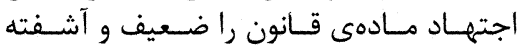

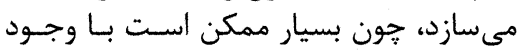

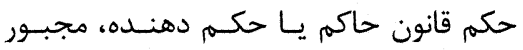

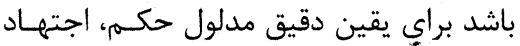
موافق با حكم قانون را بنمايد. يس لفظ اجتهاد و يـا اسـتنباطى ناجـايز

است كه مخالف مراد و مدلول قانون باشد.

مسادمى اول (Y): "در مسوردى كسه حكسمر

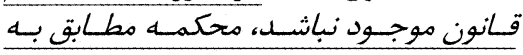

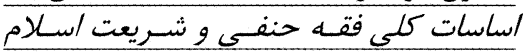

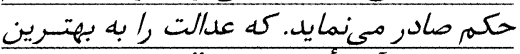

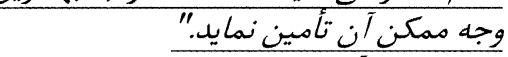

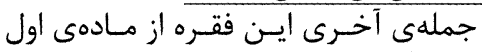

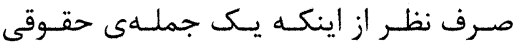

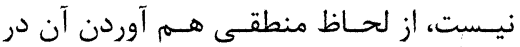

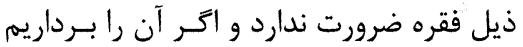

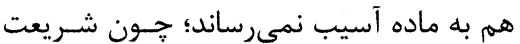

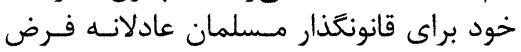
مىشود.

مادهى سوم (1): "آنجــه بـهـ زمـان ثابـت
تصويب شُهى قبلى وجود داشته است كه ما

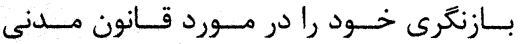

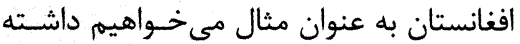
باشيمى و فقط از جهت نكارشى متعرض موان موارد

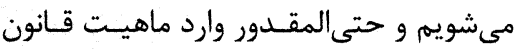

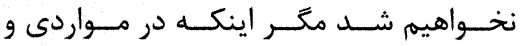

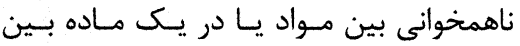

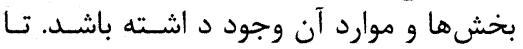

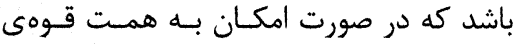

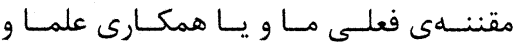

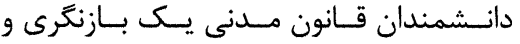
بازنغارى را تجربه كرده از نظر حجم منطقي لئسى

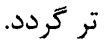
قبل از يرداختن به متن قانون يـك اصل

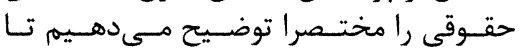

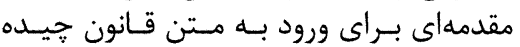
باشيم.

در علم حقوق وقتى كه مى خواهند قوانين

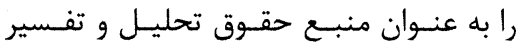
نمايند، معمول است كه مي كَويند: إقانونكذار

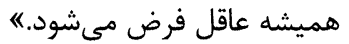

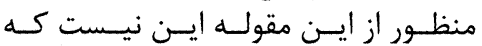

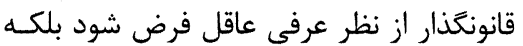

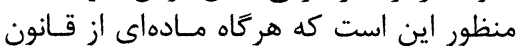

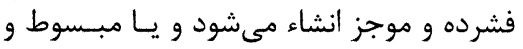

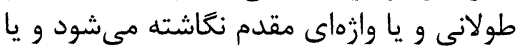

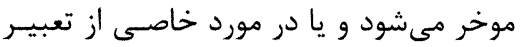

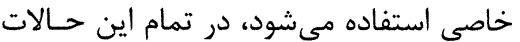

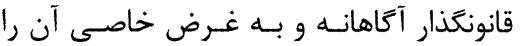

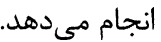

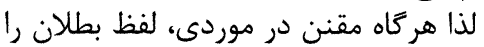

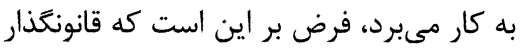

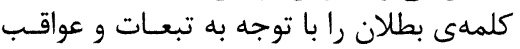

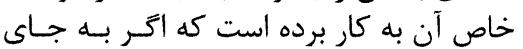

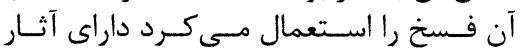

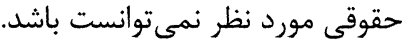

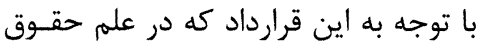

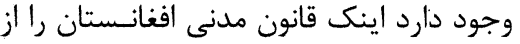

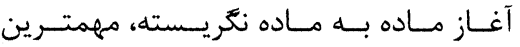

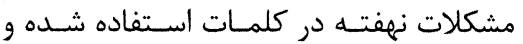

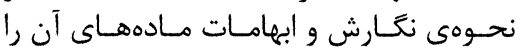

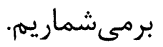
مـادهى اول: (1) "در مـواردى كسه حكسم

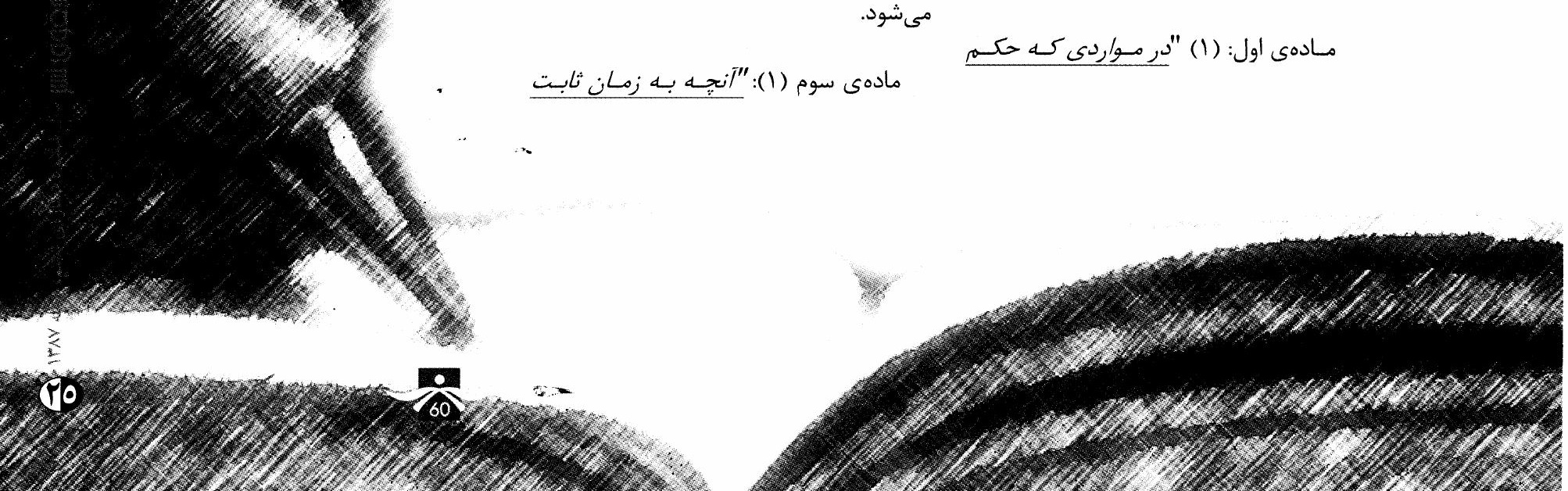


باز اكر آن را از محتواى اخلاقى آن خالى

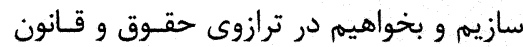

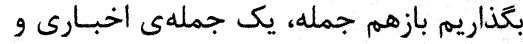

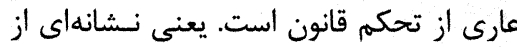

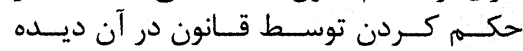

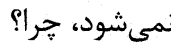
تون اين جمله كه كَفتسيم قـانون نيست

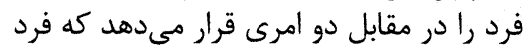

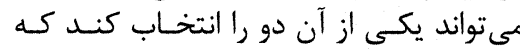

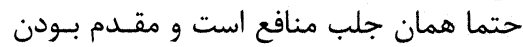

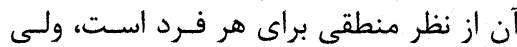

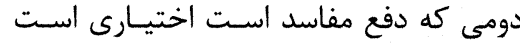

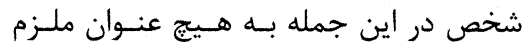

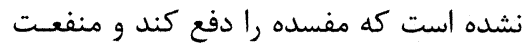

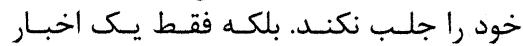

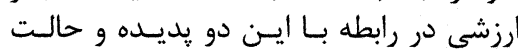

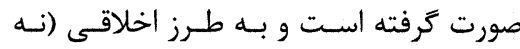

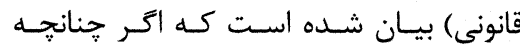

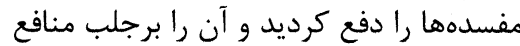

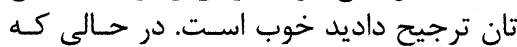

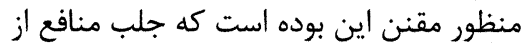

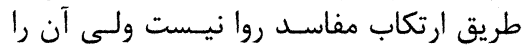

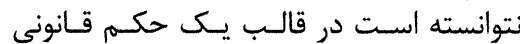

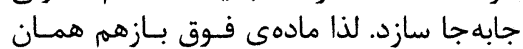

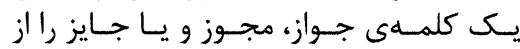

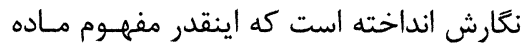

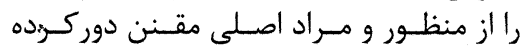

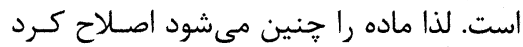

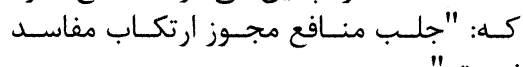

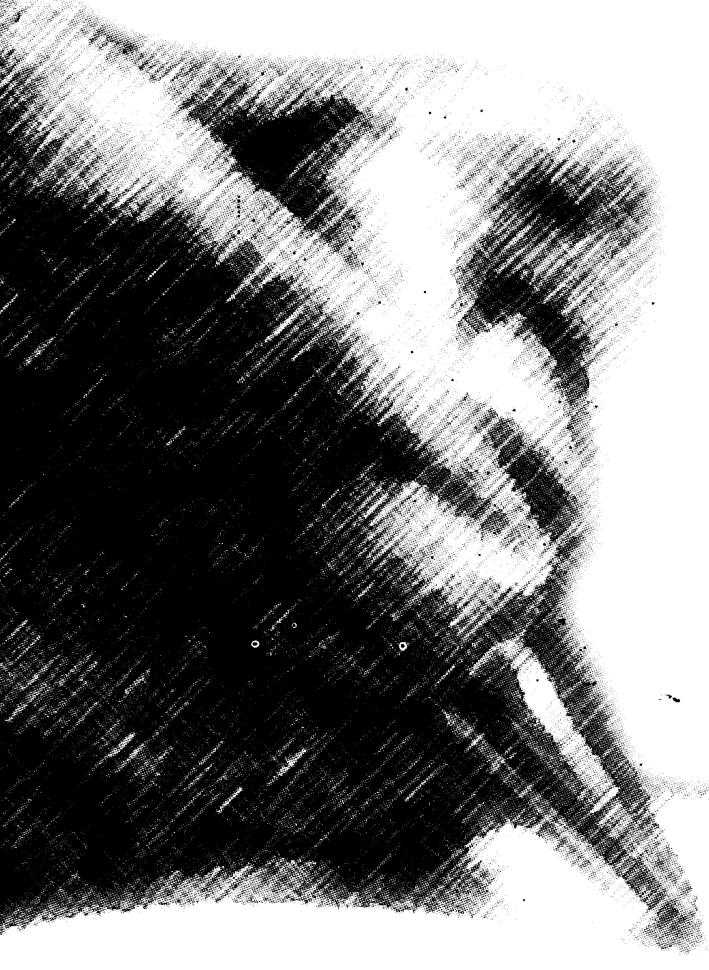

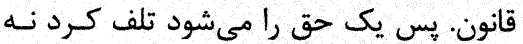
ابطال. حقى كه موجبات بطلان در در آن نباشد

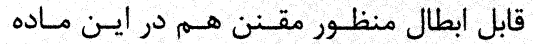
اتلاف بوده است نه ابطال ولى استعمال ابطال

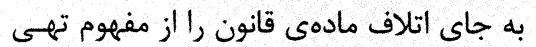

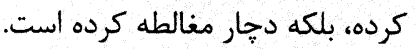

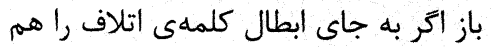

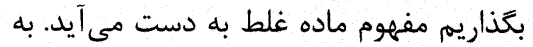

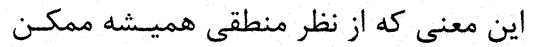

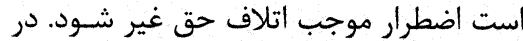

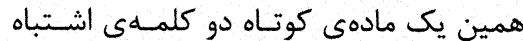

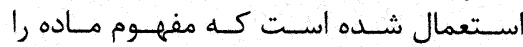

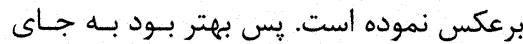

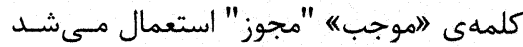

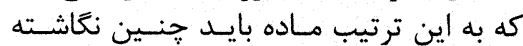
مىشد: حالت اضطرار مجوز اتلاف حـق غين غيــ

مادمى ششم: "ضرر توسط عمل بالمثل از

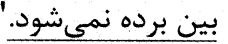

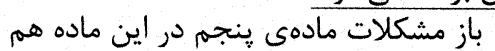

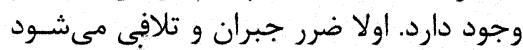
نه اينكه بكوييم از بين برده نمى إشود

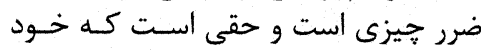

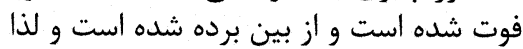

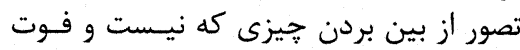

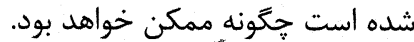
در حالى كه منظظور مقنن اصلا ايسن بـوده

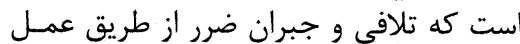

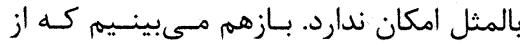

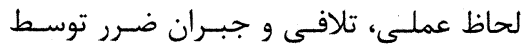

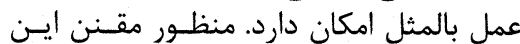

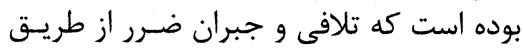

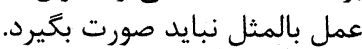

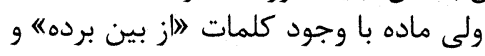

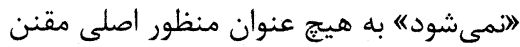

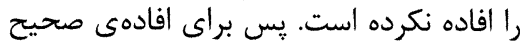

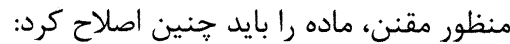

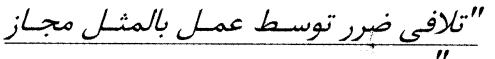

مادهى هفتم: "دفع مفاسل بر جلب منافع مقلدم مي مادمى هفلش."

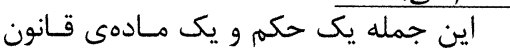

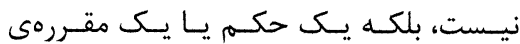

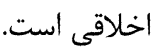

همكانى و مهلت لازم الاجرا شـدن آن استـ

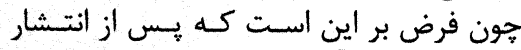

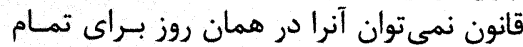

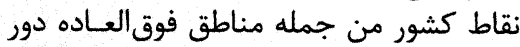

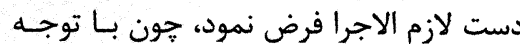

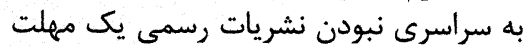
منطقى براى اطلاع عموم اتباع كشور بايد در در دري

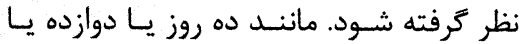

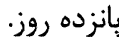
جاى اين ترتيبات و همجنين جاى همين

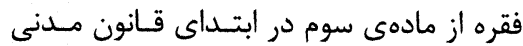

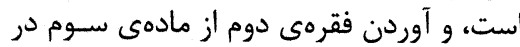

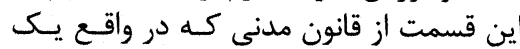

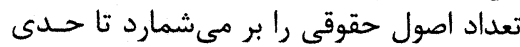

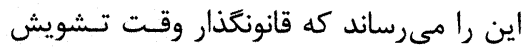

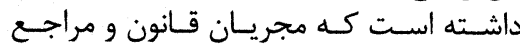

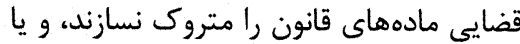

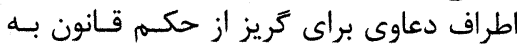
الغاى آن استناد ننمايند.

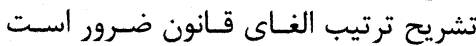
ولى نه در اين جا بلكه در اولين مواد آغـازين

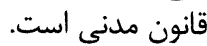

مادهى جهارم: "شخصى كه بـه اكتـساب

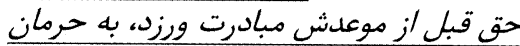

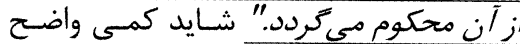

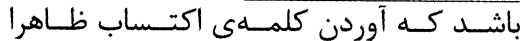

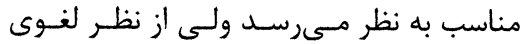

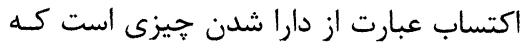
بيشتر به طور غير ارادى تحقق مسى ديابـد و واز ازيت

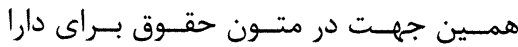

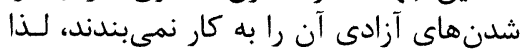
مادهى فوق را جنين مى تواند كوتاه و تكميل

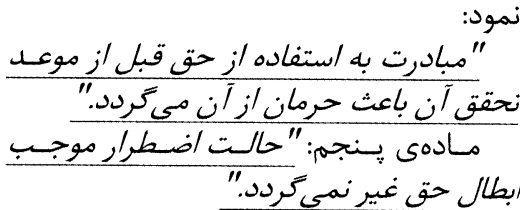
ابطال يك حق توسط كس دئ ديخرى صورت كرفته نمى تواند. براى حق بايد برايد كلمهى اتلافي

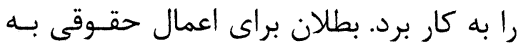

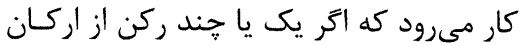

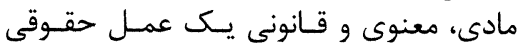

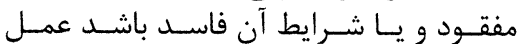

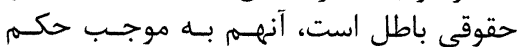




$$
\text { تولنيزي نابرابرى : }
$$

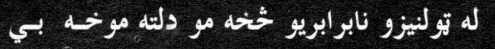

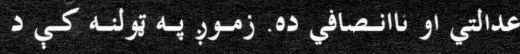
حييو بي عداليتو له امله ديو شمير خلكو نامثابي

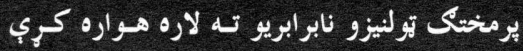

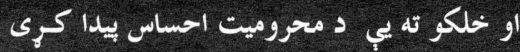

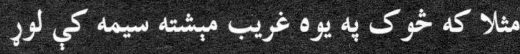

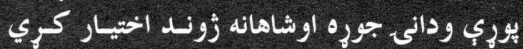

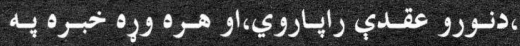

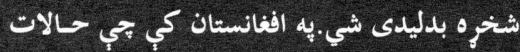

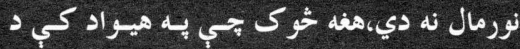

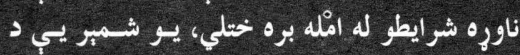

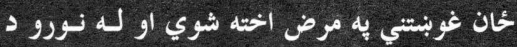
احتر ام او درناوي تمه كري. هغسه هبي وروستئه

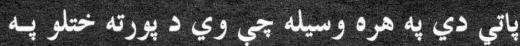

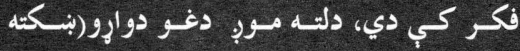
اويورته) ته كوته نيولى شو. خو بره ختلي كسان

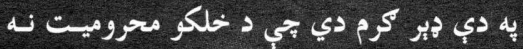
شي كلالى.

روسو وابي،هر وخت تجي تاسيو يـوه اسمان ولان

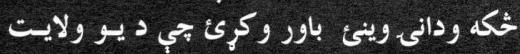

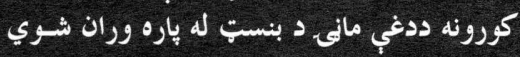

واسمه د0 تجي بله طبيعي ثول أنسان مهربانه

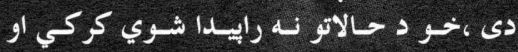

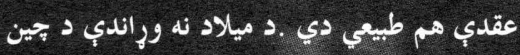

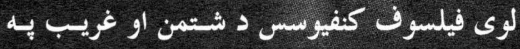
إره يوه عالمانه خبره كري نوم-ورى وائي، كله لنه
كه به هوتيل، دو كان ،بس اوياكومه اداره كي

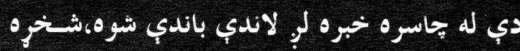
بيلبري.

فر انسوي مفكر زان زاكى روسو بـه دب انس

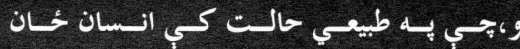

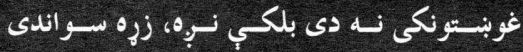

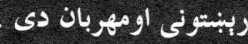

كله جي دغه مهربان انسان به خحيل جايبريكال

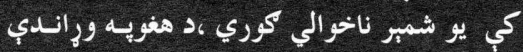

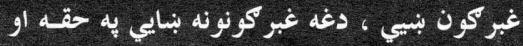

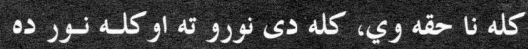

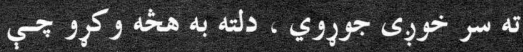
د يو خو بيلكو به را ورلو سره دغه مساله يو خه روبنانه كرو.
به تبرو دبرشو كلونو كب دافغانسانو بـه مـنخ

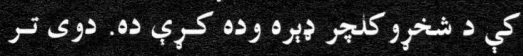

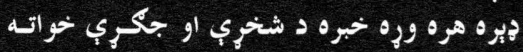

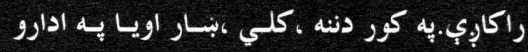

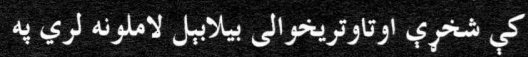

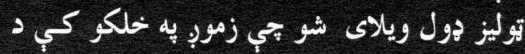

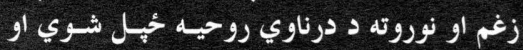

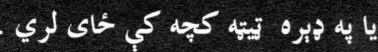

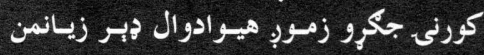

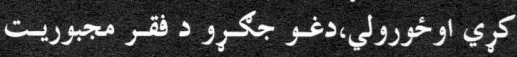

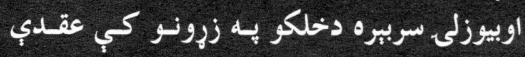

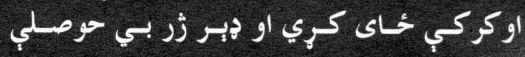

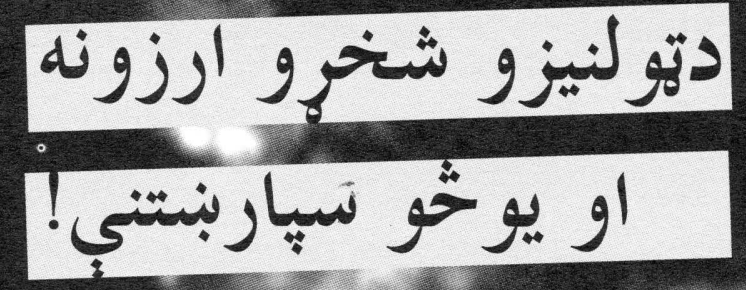

خو شال خليل 
سره زموجٍ خلك له نويو يديدو اومفاهيمو سره سرو اشنا شول، كاروي يب او عمل بري كوي.

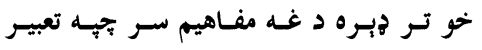

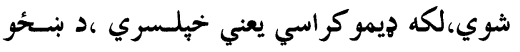
حقونه يعني بي ستري او............... كي خبره داسي نه ده.

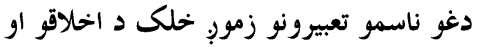

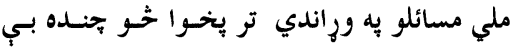

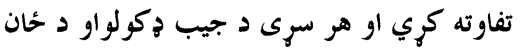

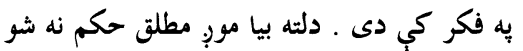

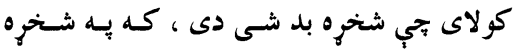
كي يو طرف تاوان ويني بل طرف كتئه كوي

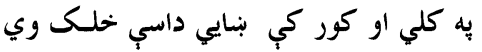

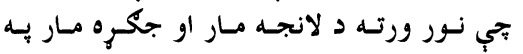

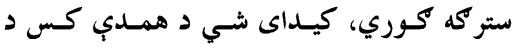

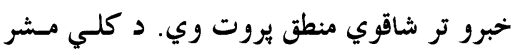

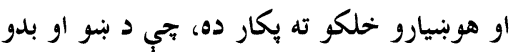

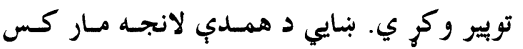

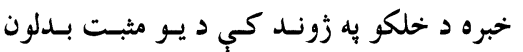

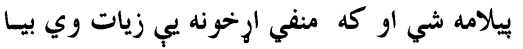

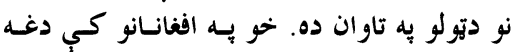

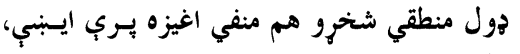

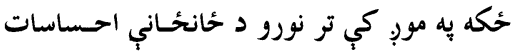

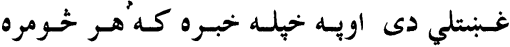

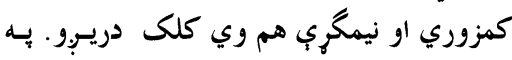
خهله خبره ولارو خلكو ته مورج نا يوه هم نه شـو

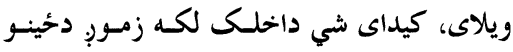

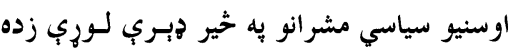

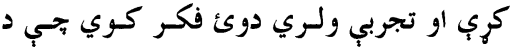

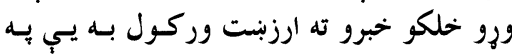
تولنه كي دريح ر اتيتّ كري او ضعيفه به بنكاره

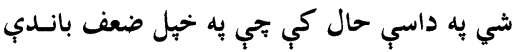

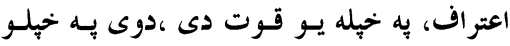

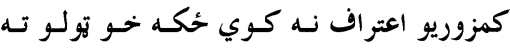
ضعيفه بنكاري. د دريحونو بي ثباتي
فكر كوي دغهه نوى حو ان بي بروا مغـروره او د حئسـو مسيئوليتونو يسه ورانسـدي بسي تفاوتسه دي.

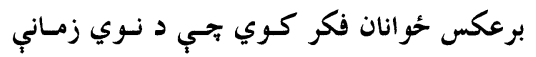

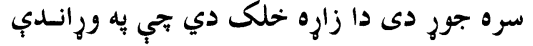

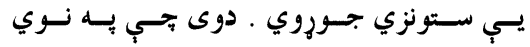

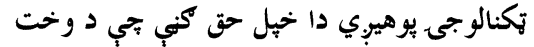

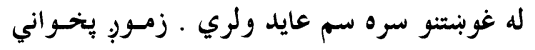

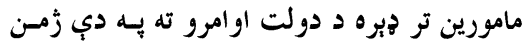

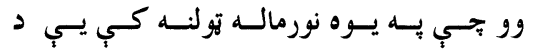

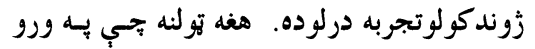

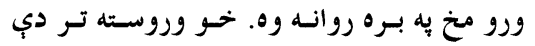

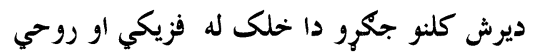
يلوه سخت و خيل شول ،خو يو لجٍ شمير يكي

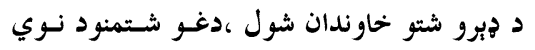

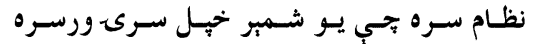

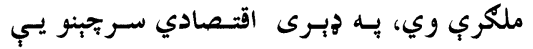

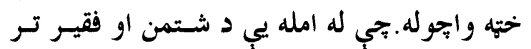

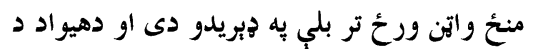

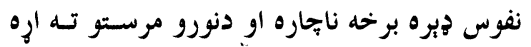
شسوه .خلسك فكـر كـوي" تسي د اوسسني نظسام زيموكراسي د اشرافو او يو خو سياسي كورنيسو

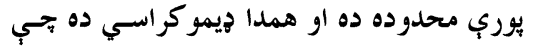

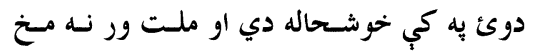

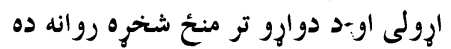
له نويو مفاهيمو سره د خلكونابلدتيا :

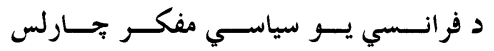
مونتيسكيو يه خيل هيواد كي دسياسي لبر اليزم يو ليو

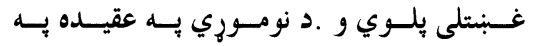

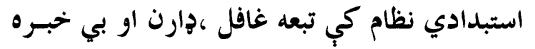

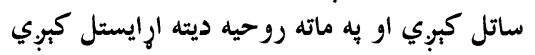

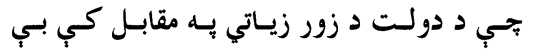
يوبنتني اطاعت و كري دوي دوري

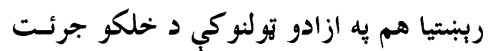

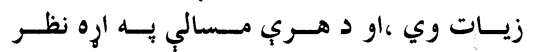

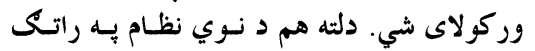

يجي دي تولنه بيوزله وي او تـه يـه كي شـاهانه

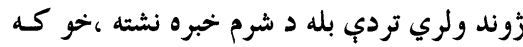

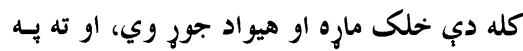

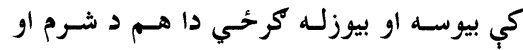

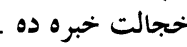

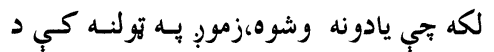

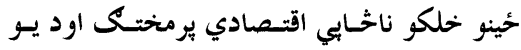

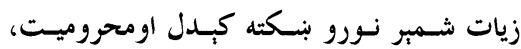

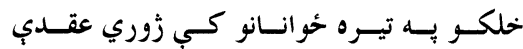

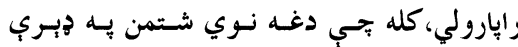

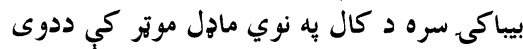

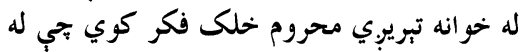

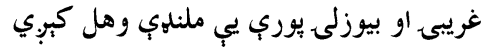

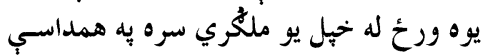

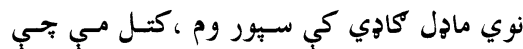

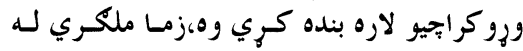

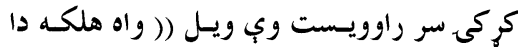

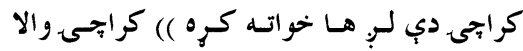

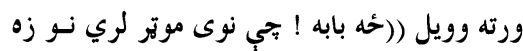

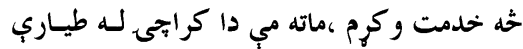

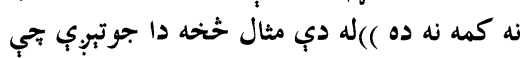

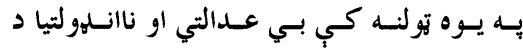

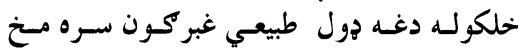
كِبִ̣ي د امتيازاتو يه وركره كي لوى تويير:

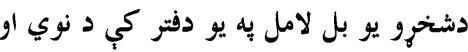

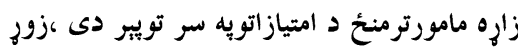

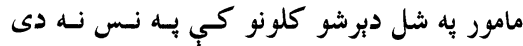

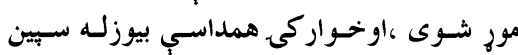

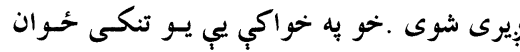

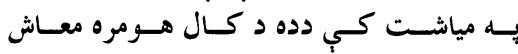

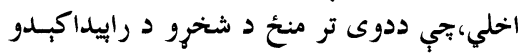

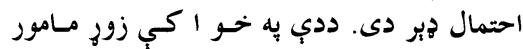


استعداد ودي ته متوجه كبوب. كله هـي بـه يـوه

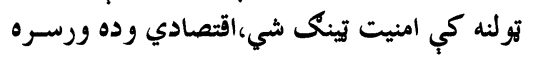

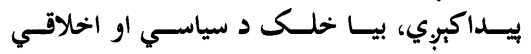

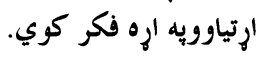

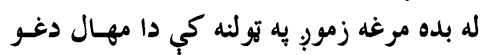

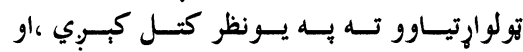

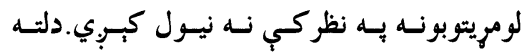

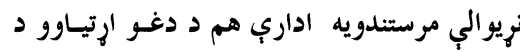

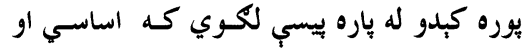

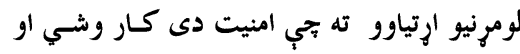

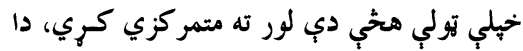

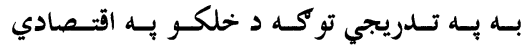
ودي،اخلاقو او يه زغم مثبت تاثير وكري. ئهي.

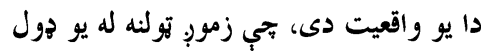

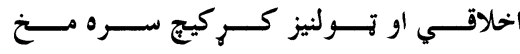

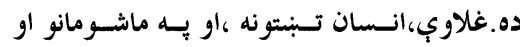

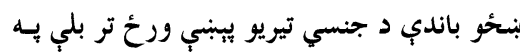

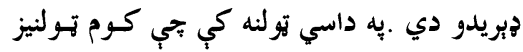

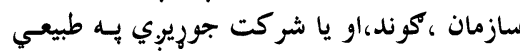
توكه دا ستونزب هغه سازمانونو ته هم ورننوزي.

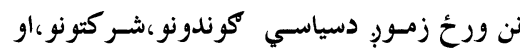

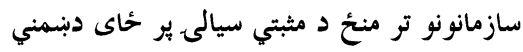

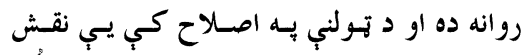

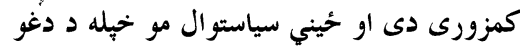

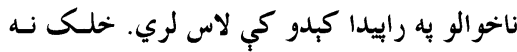

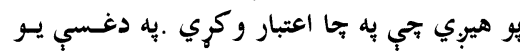

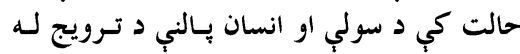

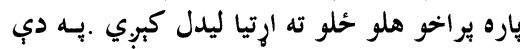

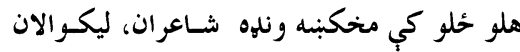
او هنرمندان لري.

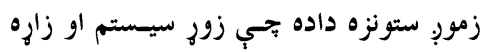

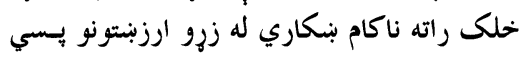

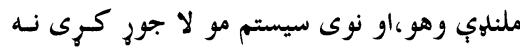

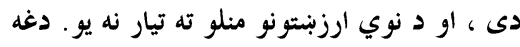

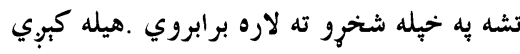

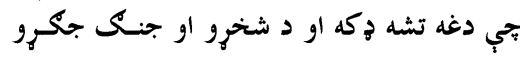
كجهه ورسره راتيته شي.
وس اكثره خلك يه دي قانع نه دي حِي پِه خهله

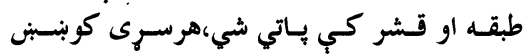
كوي تجي له خجيلي طبقي بورته بلي يوري تهي ته

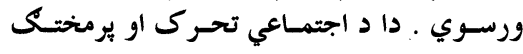

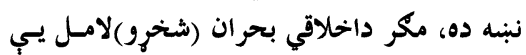

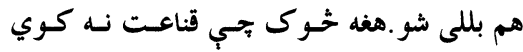

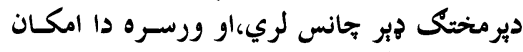

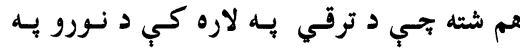

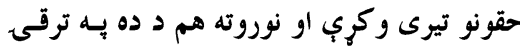

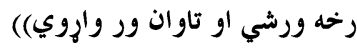

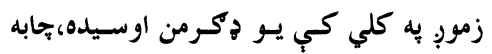

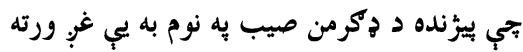

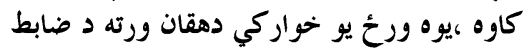

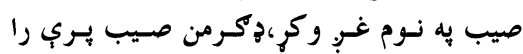

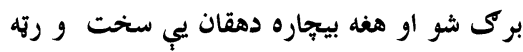

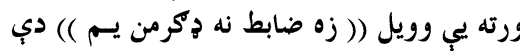

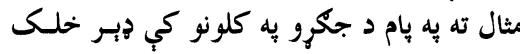

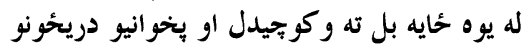

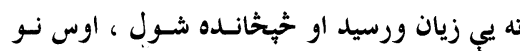

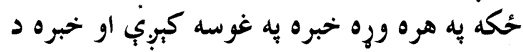
شخري تر سرحده رسوي

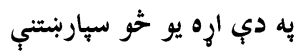

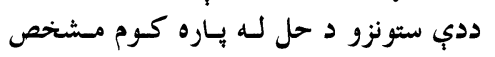

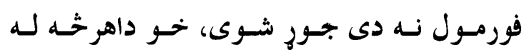

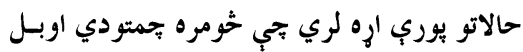

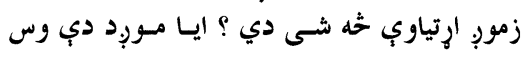

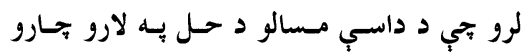

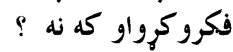

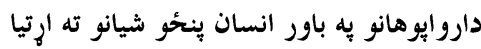

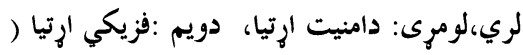

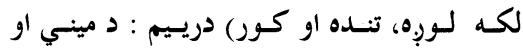

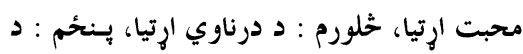

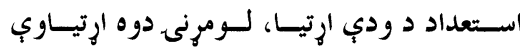

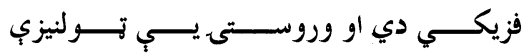

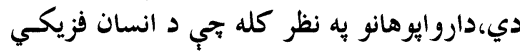

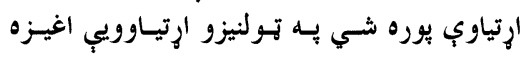

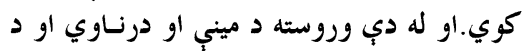

كه د يو يحا دريخ هي يوه برخه كي لورج ختلسى

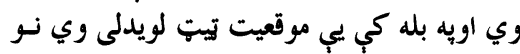

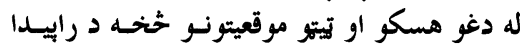

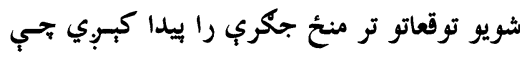

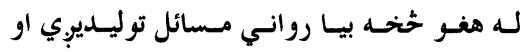
شخرو ته لاره هواروي

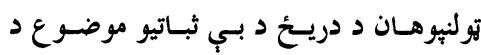

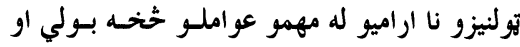

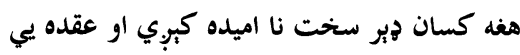

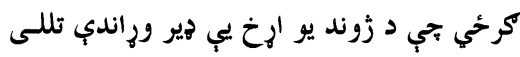

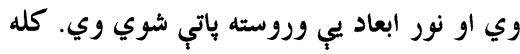

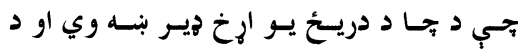

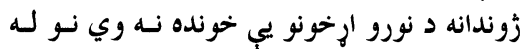

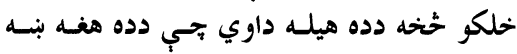
ارخ يه نظر كي ونيسي.

استاد وجدي بـه خجيـل كتـاب ((دزرونسو او نيسي

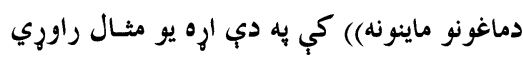

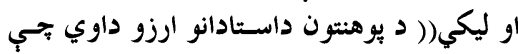
خلك بايد ددوى علمي رتبي يه نظر كي ونيسي دي دوني

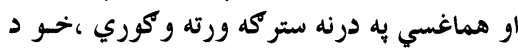

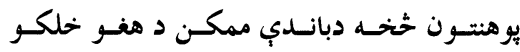

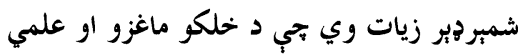

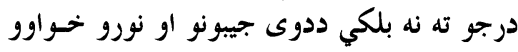

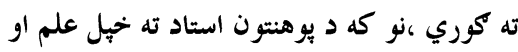

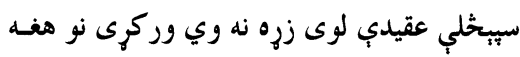

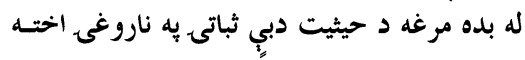

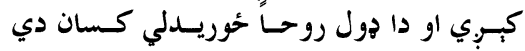

وتلى ليكوال اسدالله غضنفر يهـ خهيلي يـوي

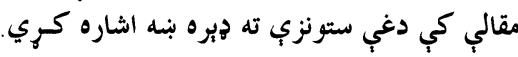

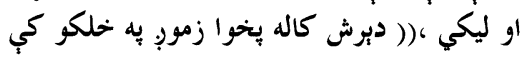

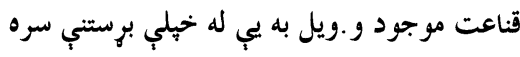

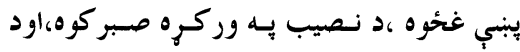

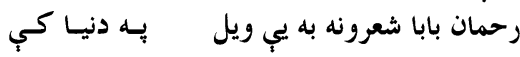

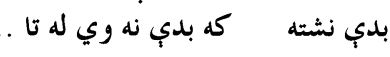

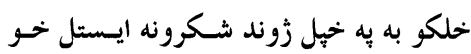


اخلاق و سياست حقوق بشر حقوق شهروندان حقوق زمامداران

منبع : روزنامهى هم ميهن س/F

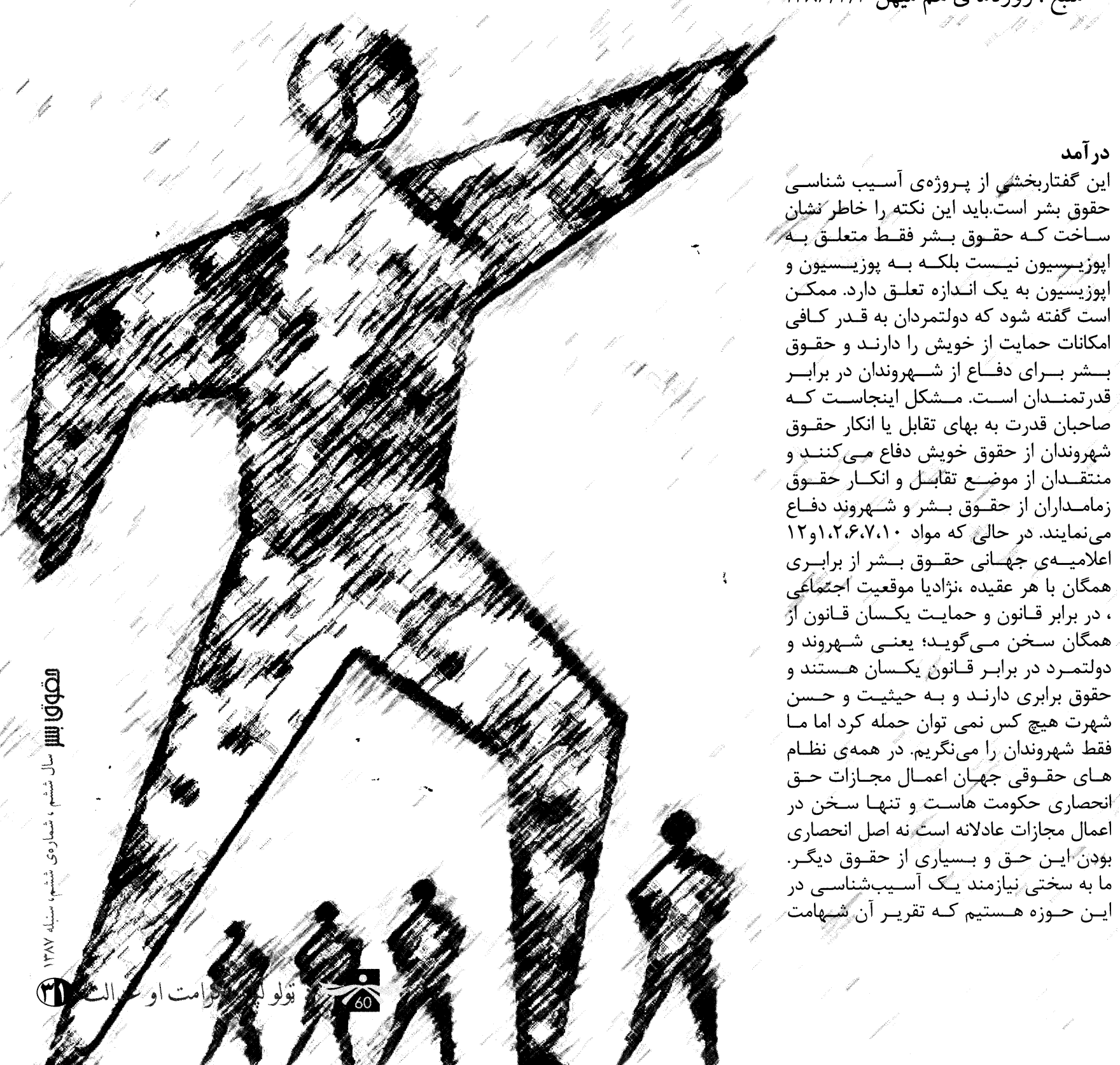




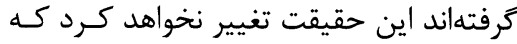

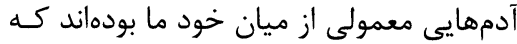
برحسب تصادف يا تدبير بــه ايسن جايخـاه راه راه

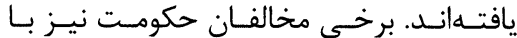

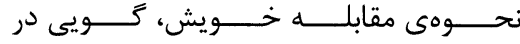

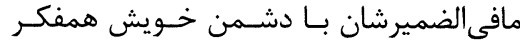

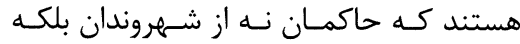

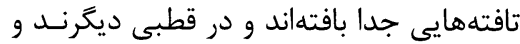

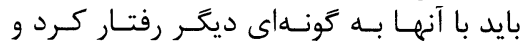

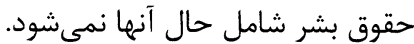
اركان حقوق بشر: دو ركن حقوق بشر شامل بشر: حال هر انسانى بـه إنه

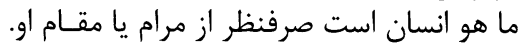
اول: عدالت دوم: اخلاق.

عدالت: مد

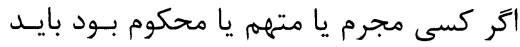

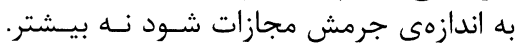

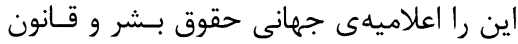

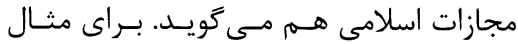

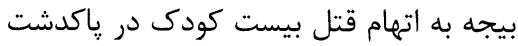

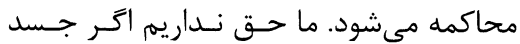

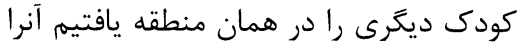

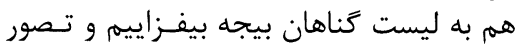

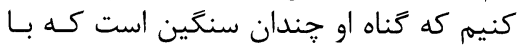

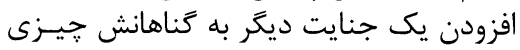

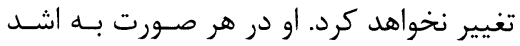

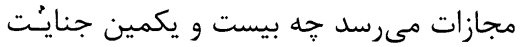

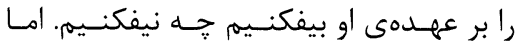

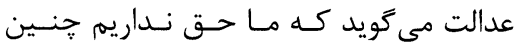

كنيم.

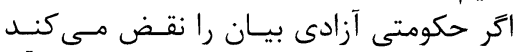

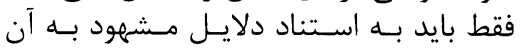

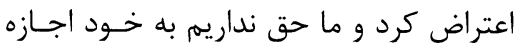

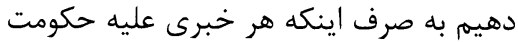

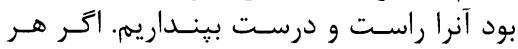

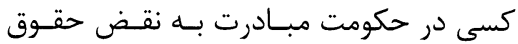

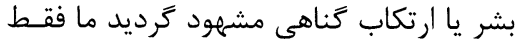

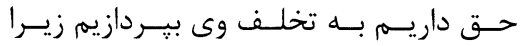

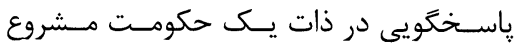

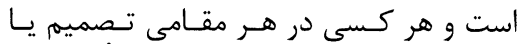

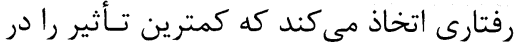

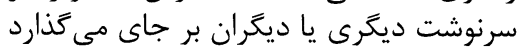

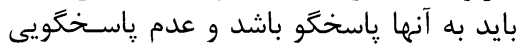

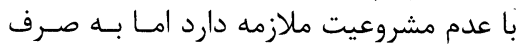

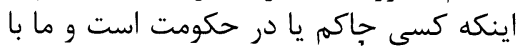
آن مخالفيم مجوز انتساب هر هر راست و دو دروغى استى به او نمى مختود.

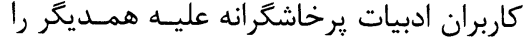

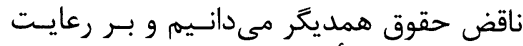

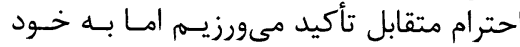

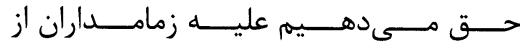

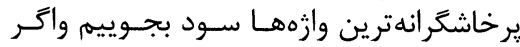

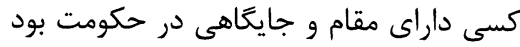

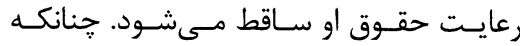

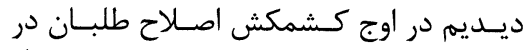

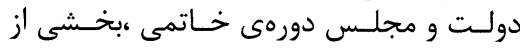

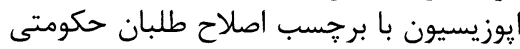

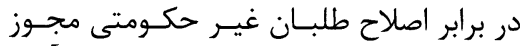

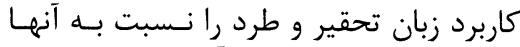
صادر كردند و نتيجه اش آن آن شد كه دير ديـديم.

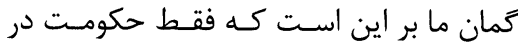

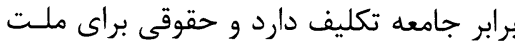

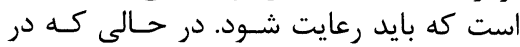

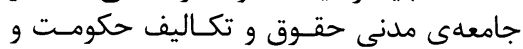

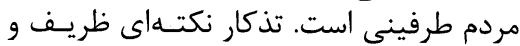

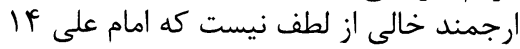

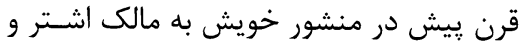

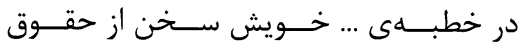

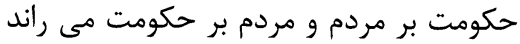

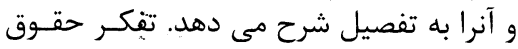

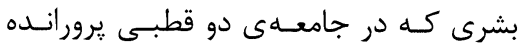

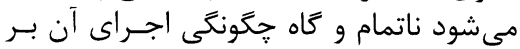

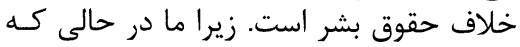

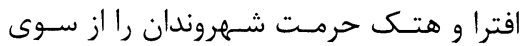

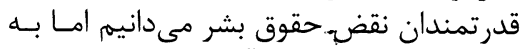

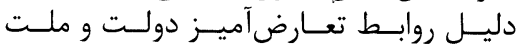

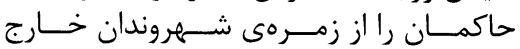

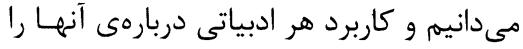

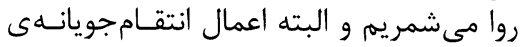

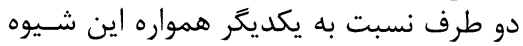

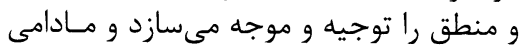

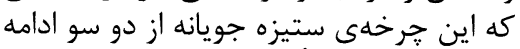

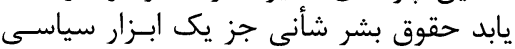

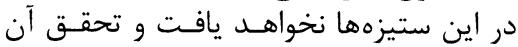

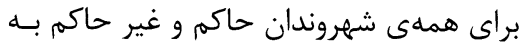

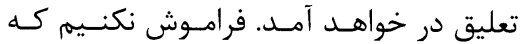

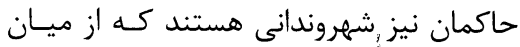

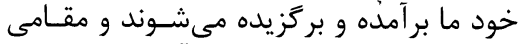

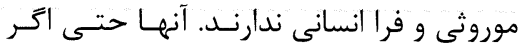

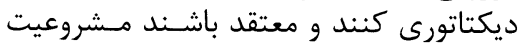

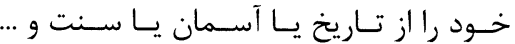

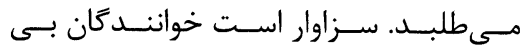

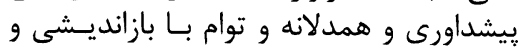

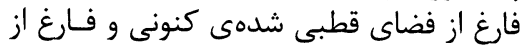

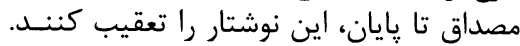

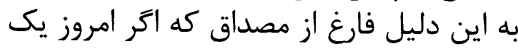

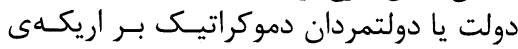

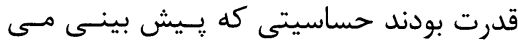

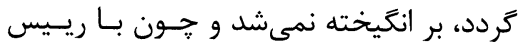

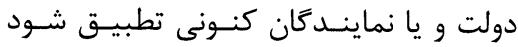

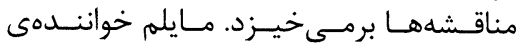

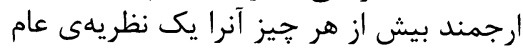
و كلى انخارد.

\section{فراتيرى حقوق بشر، قربانى ستيز دولت - ملت اكتيرى}

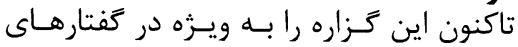

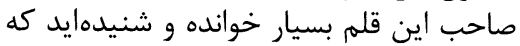

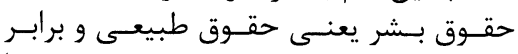

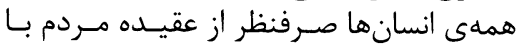

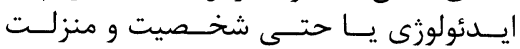

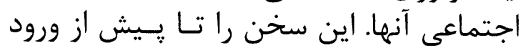

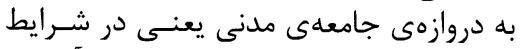

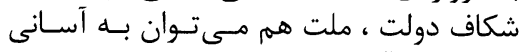

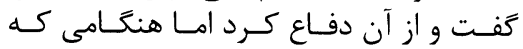

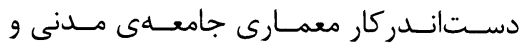

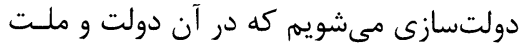

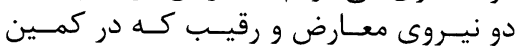

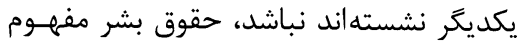

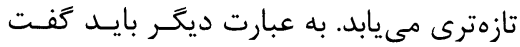

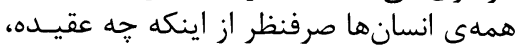

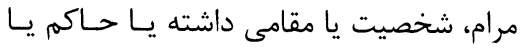

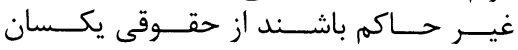

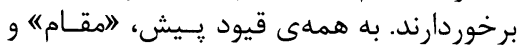

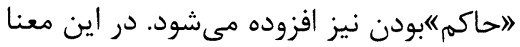

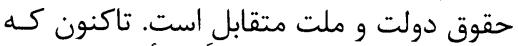

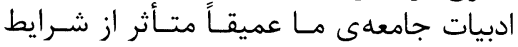

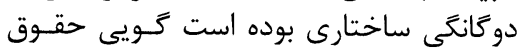

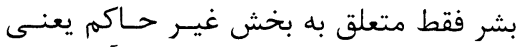

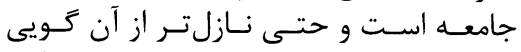

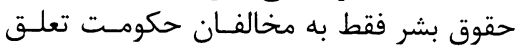

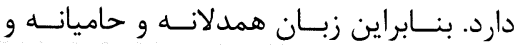

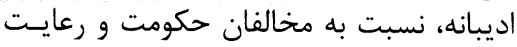

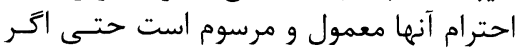

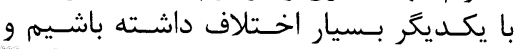

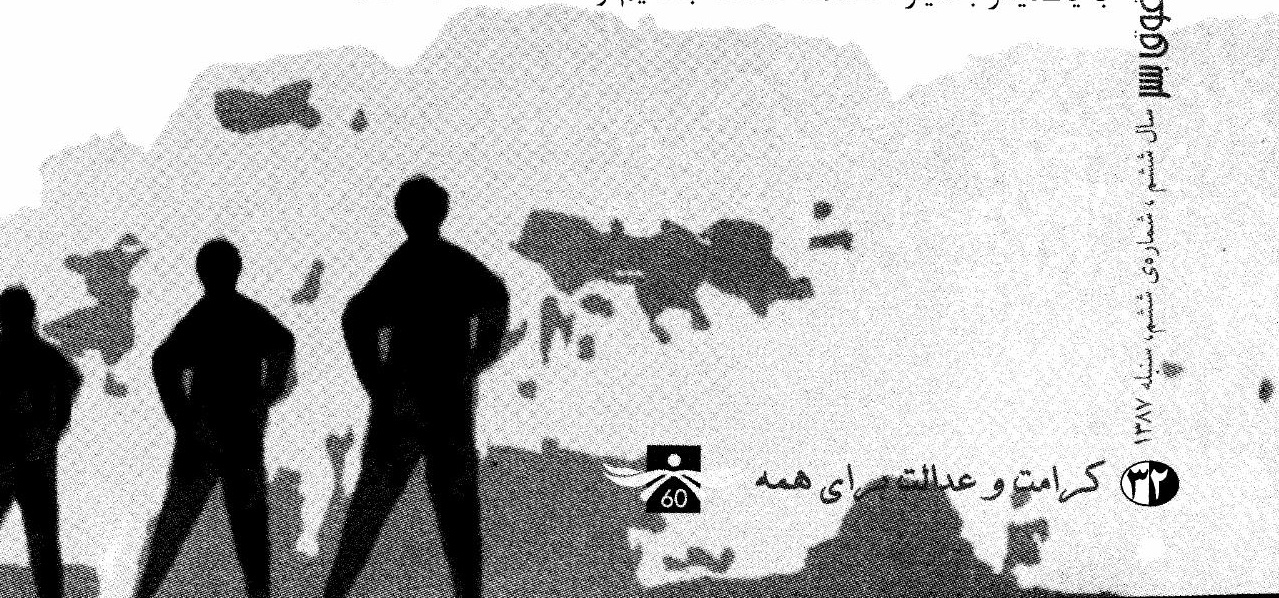




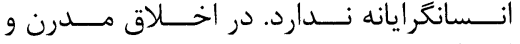

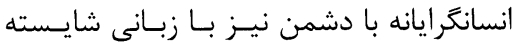

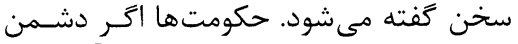

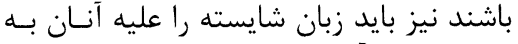

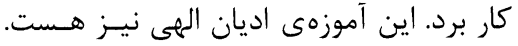

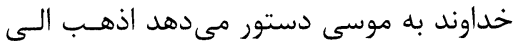

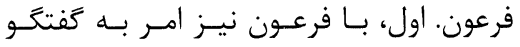

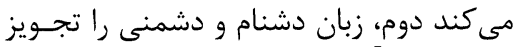

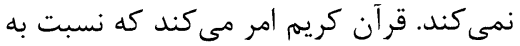

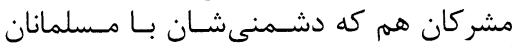

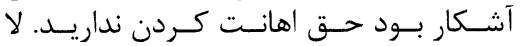

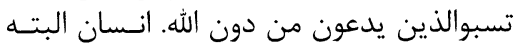

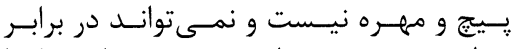

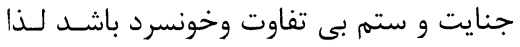

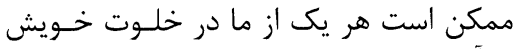

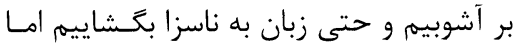

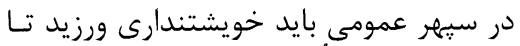

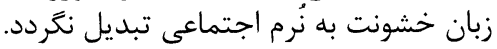

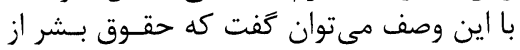

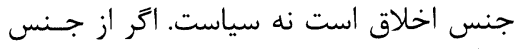

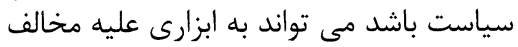

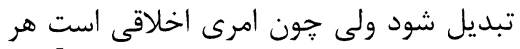

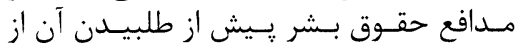

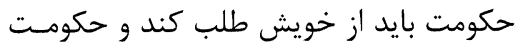

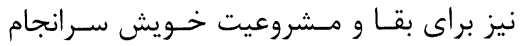

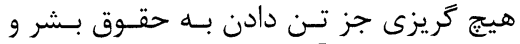
التزام اخلاقى به آن ندارد.
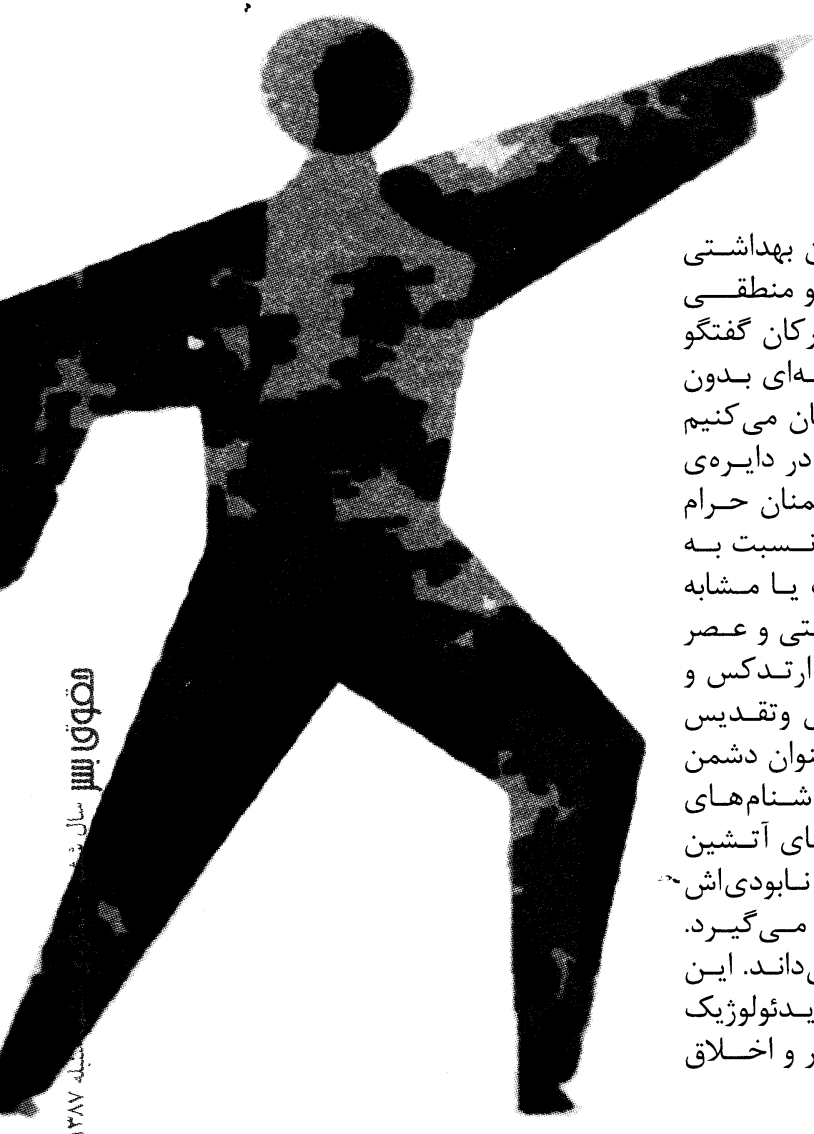

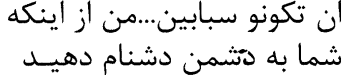
بيزارم ودر حالى كه بــــا آنــهـا

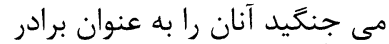
خود دعا كنيد جنيد انان اخلاق

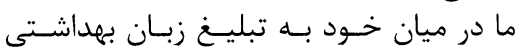

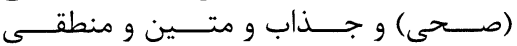

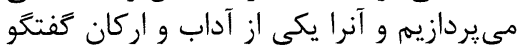

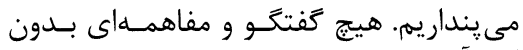

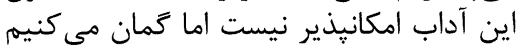

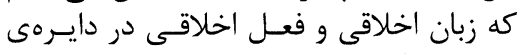

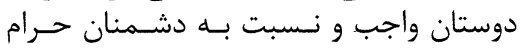

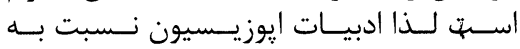

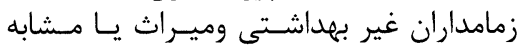

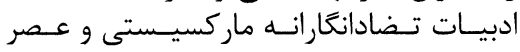

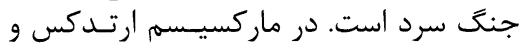

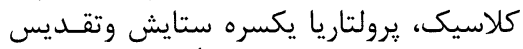

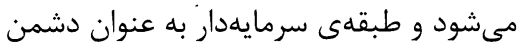

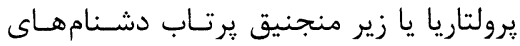

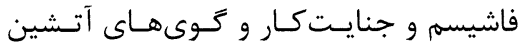

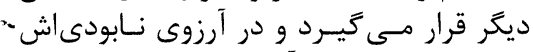

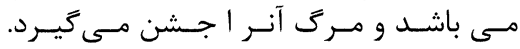

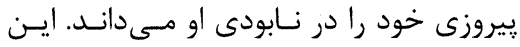

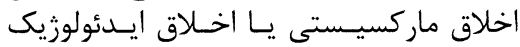

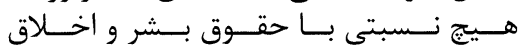

تصور كنيد كه اخر به شما اتهام قتلى نـاكرده

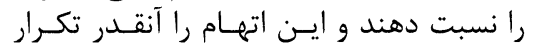

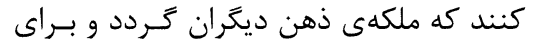

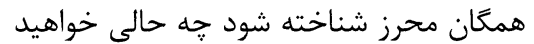

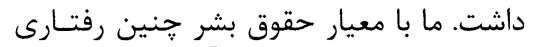

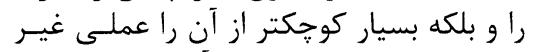

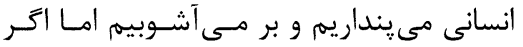

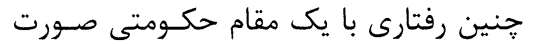

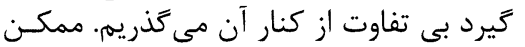

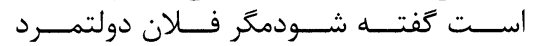

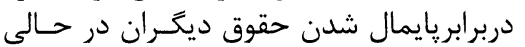

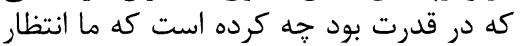

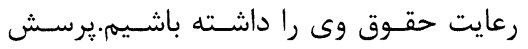

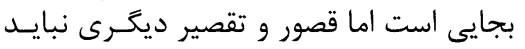

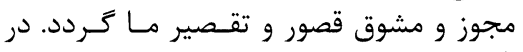

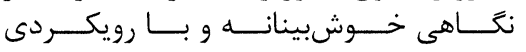

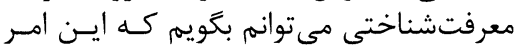

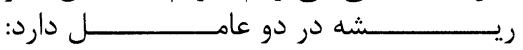

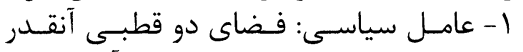

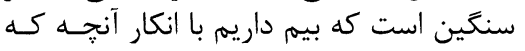

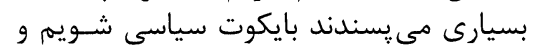

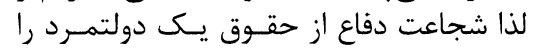

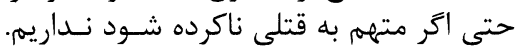

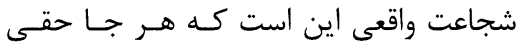

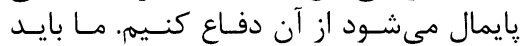

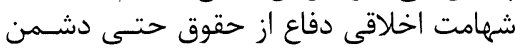

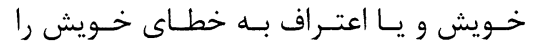

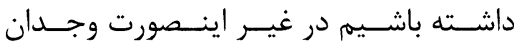

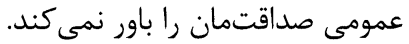

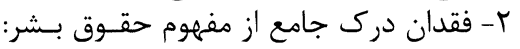

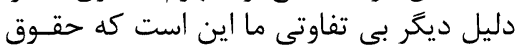

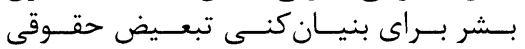

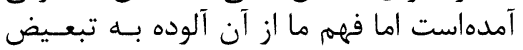

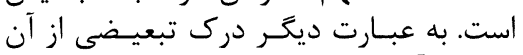

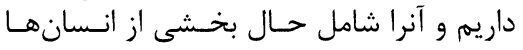

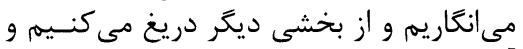

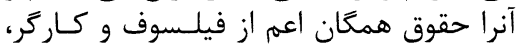

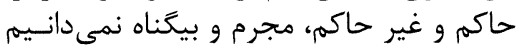

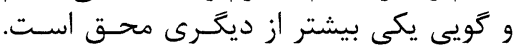

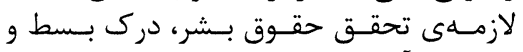

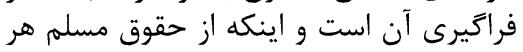

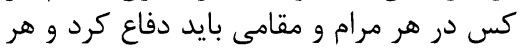

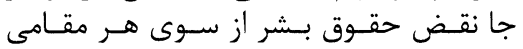

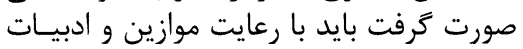

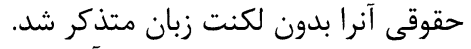

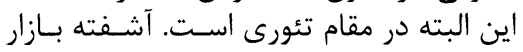

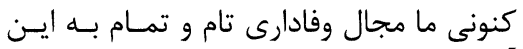

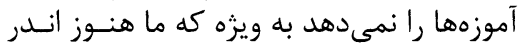

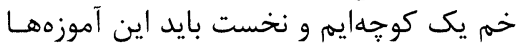

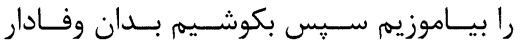

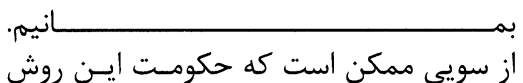

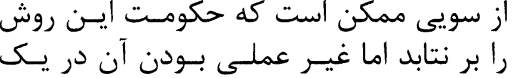



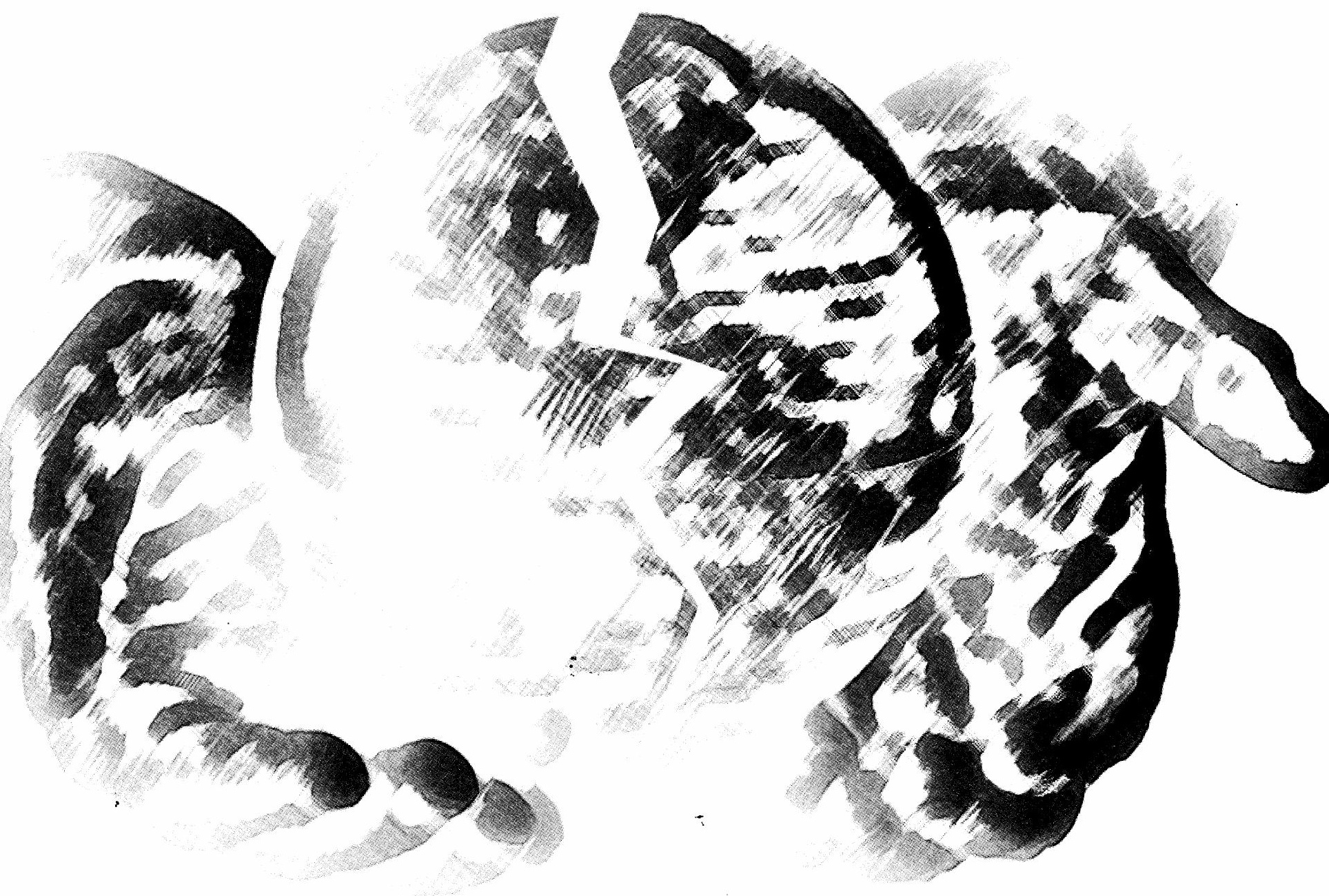

\section{به نهيو الو عمومي حقوقوكي مويدات}

واخيستل شي. موخسه مي داده جي يـه خيله

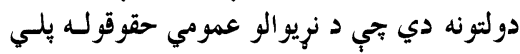

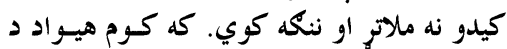

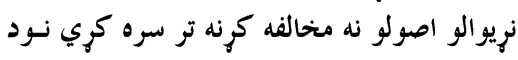

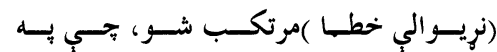

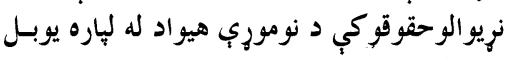

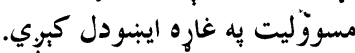

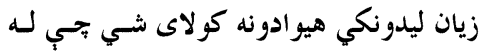

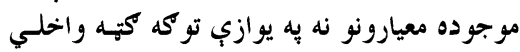
او همدغه شان كولاى شي تجي د نورو هيوادونو تهي
شخصيتونونه يرته نور دير لور شخصيتونه شستون

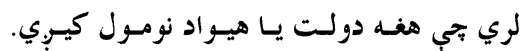

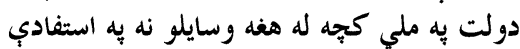

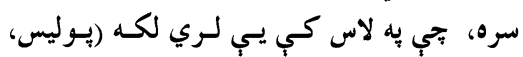

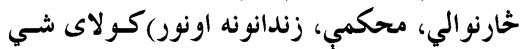

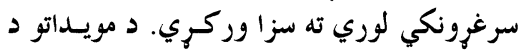

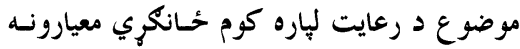

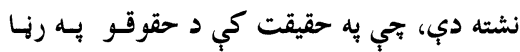

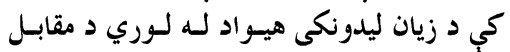

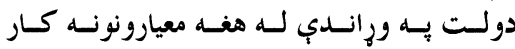

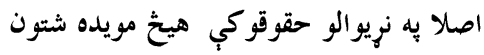

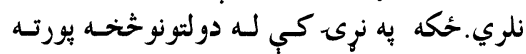

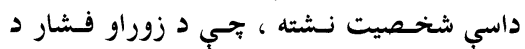

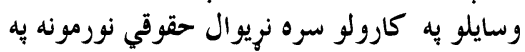
دولتونو باندي بلي كري.

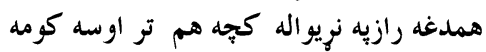

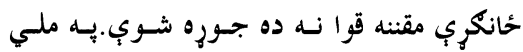

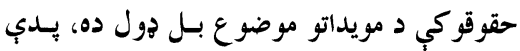

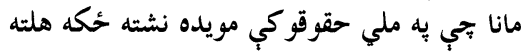

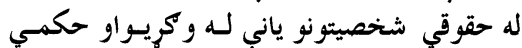


دا هغه معيار د دى تجي د يوهيواد يـه قـانوني

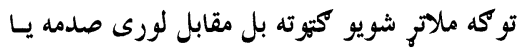

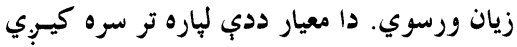

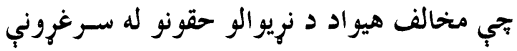

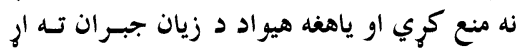

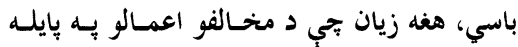

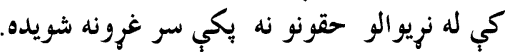

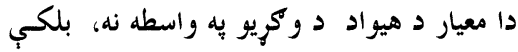

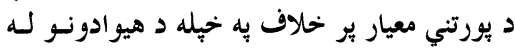
لورى ورباندي لاس يوري كيوي .

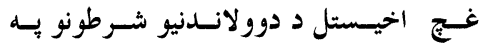
موجوديت كي قانوني بلل كيري: لومي: د مقابل لوري هغه ناقانونه كرني تئي

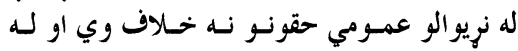

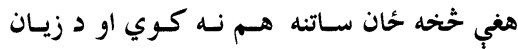

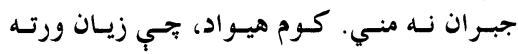

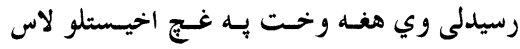

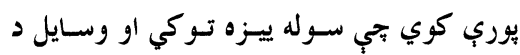

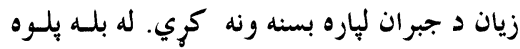

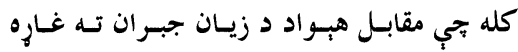

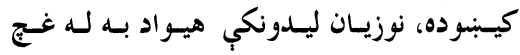

$$
\text { اخيستني نه لاس اخلي . }
$$

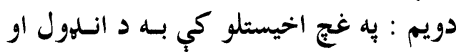

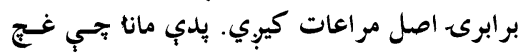

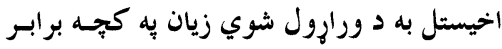

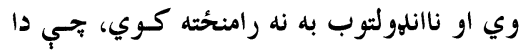

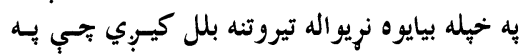

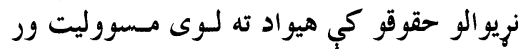
ترغاري كوي.

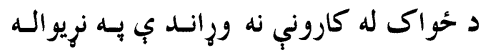

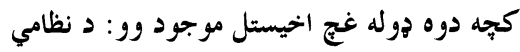

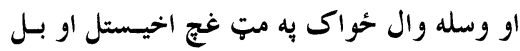

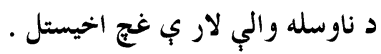

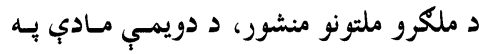

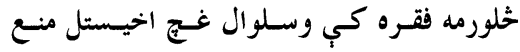
كراى شول اويدي فقره كي داسي راغلـي دي وني

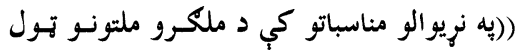

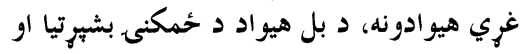

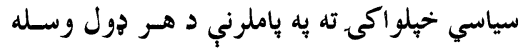

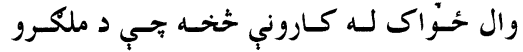
ملتونو له موخو سره به تخكر كي وي، بايسد حسـان

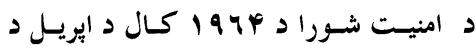

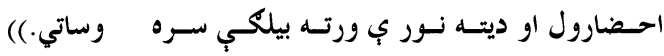

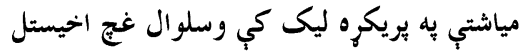

منشور ير بنسست دا صـلاحيت او ورتيـا لـر ي،

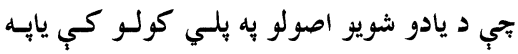

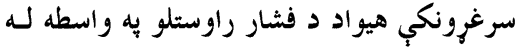

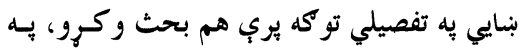

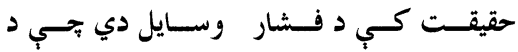

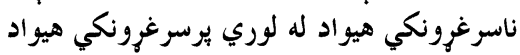

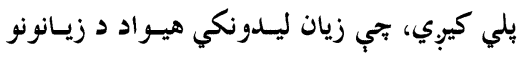

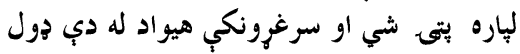

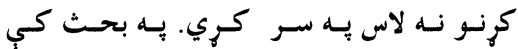

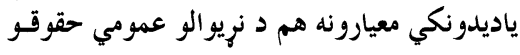

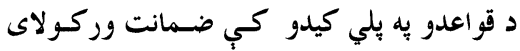

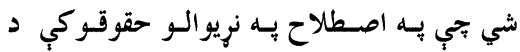
مويدي به نوم تري كار اخيستل كيهِي. د يادوني ورج معيارونه دادي: 1 - إنبر ان يا ورته غبر كون.

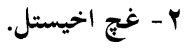

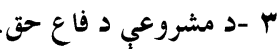

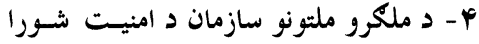
له لوري توليز اقدامات. أ 1 تلافي يا غبركون تر تولو نرم، اسانه او د بنسه وتهي

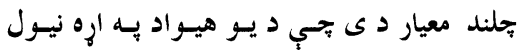

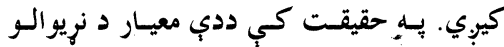

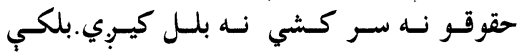

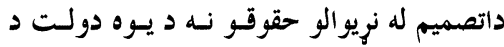

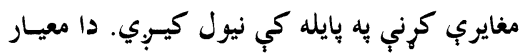

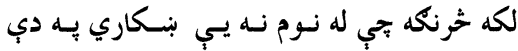

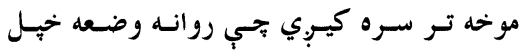

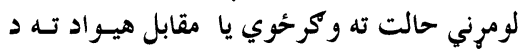
ورته جلند حئواب وركـري. ددب معيسار يـه يلي وني

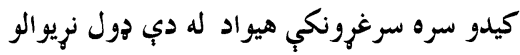

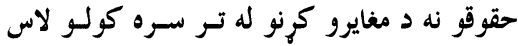

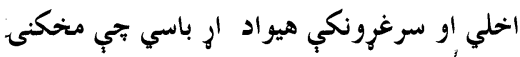

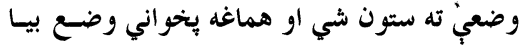

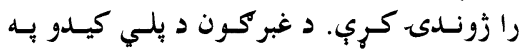

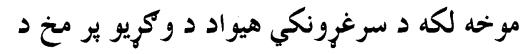

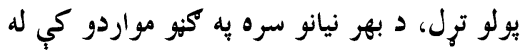

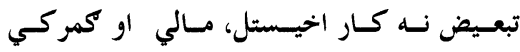
محصولات، د قونسليو د موافقت ليكونسو بيرتسه

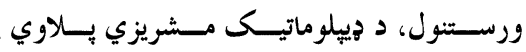
رانغاري.

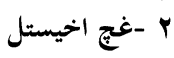

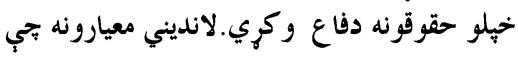

به مرسته به توليزه توكه د سرغرونكي هيسواد يسه

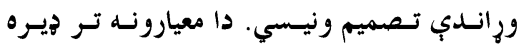

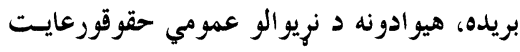

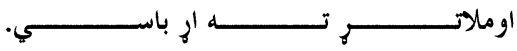
ايرانى ليكوال (بيكدلي) ((يه نريوالو حقوقو كي دي دي

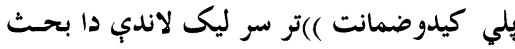

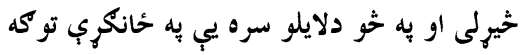

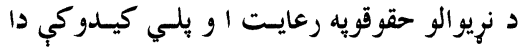

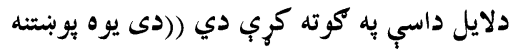

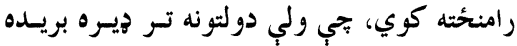

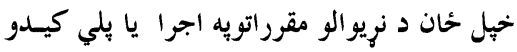

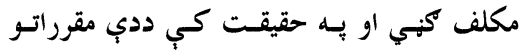

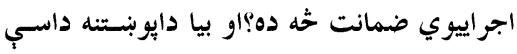

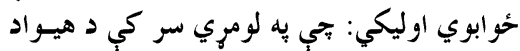

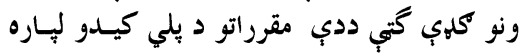

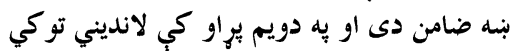



كيدو د ضمانت لباره تر يوه بريده بسنه كوي: 1 -د متقابلو كتو د ساتني ارتيا. Y -د اخلاقي مسووليت احساس او درى

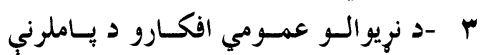
راجلبول.

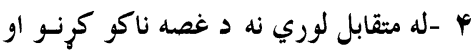
اقداماتو ويره (لكه جكهه.)

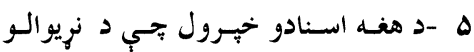

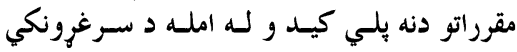

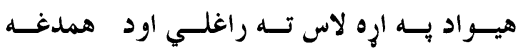
سرغرونكي هيوادله لوري ترسوه شوره لادي هم دي.

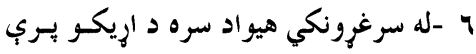

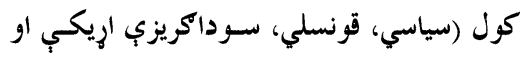
نور ·.

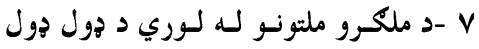
يريكرونيول.

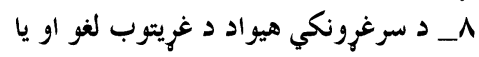

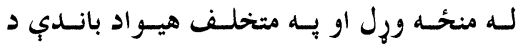

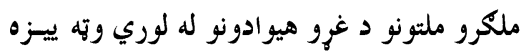

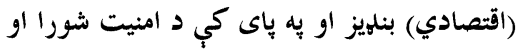

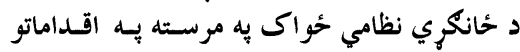
لاس يوري كول. بِ حقيقت كي دولتونه به بهرني سياست كي لوري

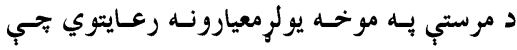

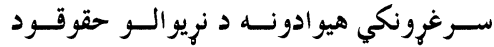

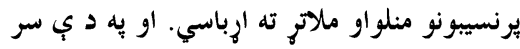

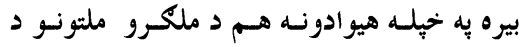




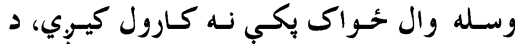
ملكرو ملتونو سازمان د منشور به يه يو خحلويسبنتمه ماده كي داسـى خر گنسـديزي:((د امنيست شـورا

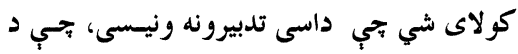

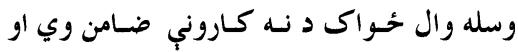

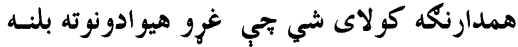

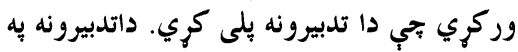

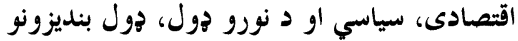

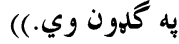

د يورتنيو تدبيرونو عملي بيلكي يادور: 1

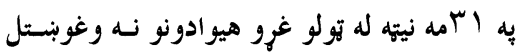
جي برتكال هيواته هر راز مرسته ودروي.

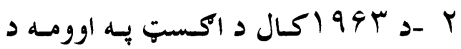

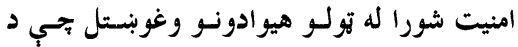

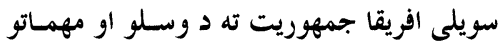
برابرول اوخر خملاو ودروي.

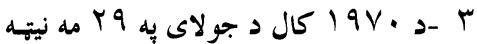
د امنيت شورا له تولو هيوادونو خخهـه وغوبنستل جي له سويلي افريقا سره د هر راز اريكونه، لكه

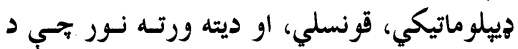

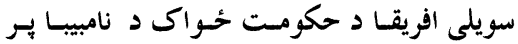
قلمرو ثبوتوي، حخان لري وساتي.

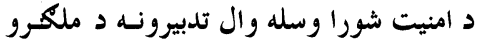

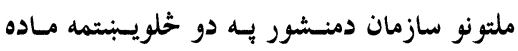

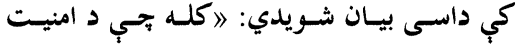

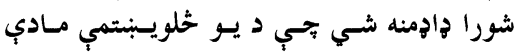

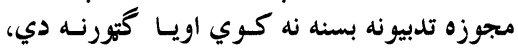

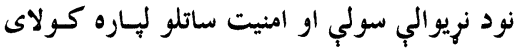

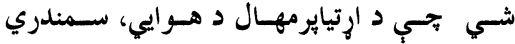

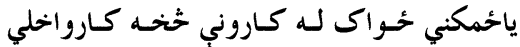

ل ل

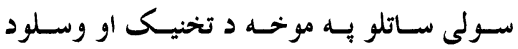
كاروني بير خرنكوالي خبري كري دئ دي.

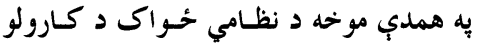

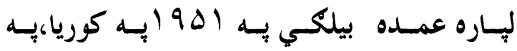

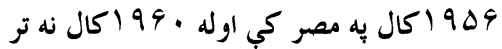

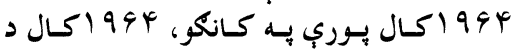

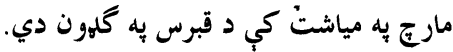

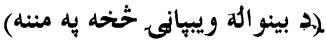

شـورا د سـولي او تيكـاو د سـاتلو يـه اره اريسن

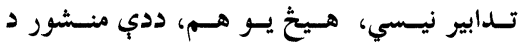

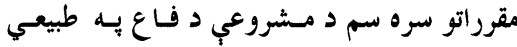

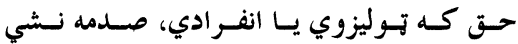

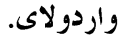

هغه تدبيرونه تجي د غريو هيوادونو لـه لـورى د مشروعي د فاع لياره نيول كيوبي، بايد له خُنله

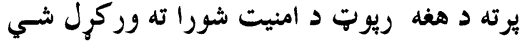

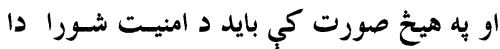

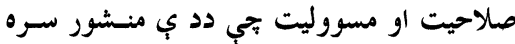

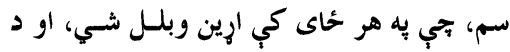

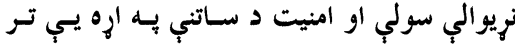
سره كوي، اغيزمن نكري.)

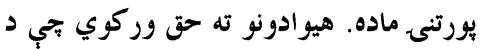

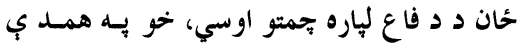

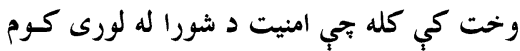

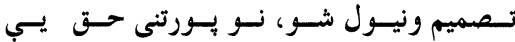

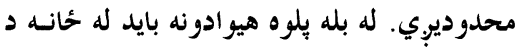

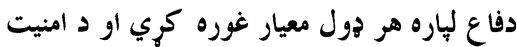

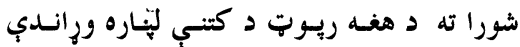
كري.

د يـورتني معيـار او غـج] اخيسستني د معيـار

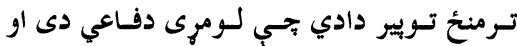

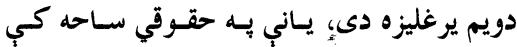

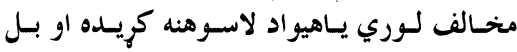

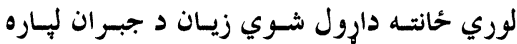

† - مد ملكرو ملتونو د امنيت شورا واكونه:

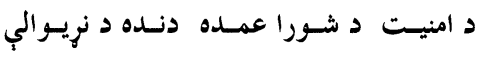
سولي او امنيت ساتل او د هر دول خطر له منحُ دوله

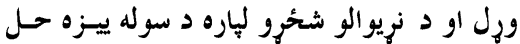

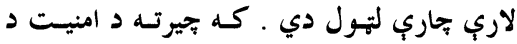

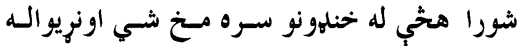

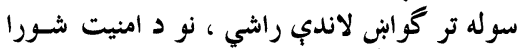

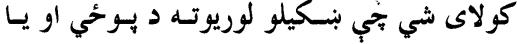

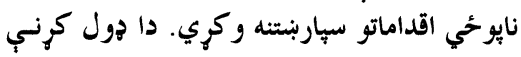
د نريو الو حقوقـو لـه نظـره د مويسلدي دنسـده ده.

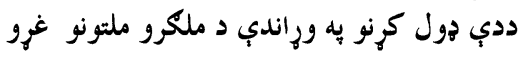

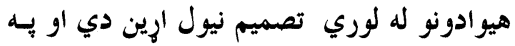
سرته رسولو كي به يي هم خيل مكلفيت له بامسه نه غورحوي.

د امينست د شــورا اقــدامات بـهـ يايسه تــوليزه

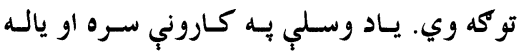

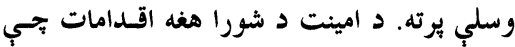

منع كرل او دا يي د ملكرو ملتونو له اصسولو نسه

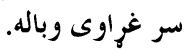

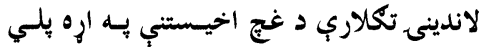
كيوي: 1 - له خبلو سيمونه د بل هيواد د تولورگٍرو

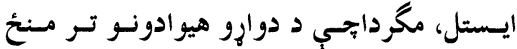
ددي خحلاف ترون شوى وي.

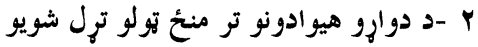

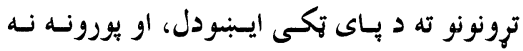

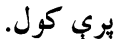

r -د مقابل لوري د سواحلو او بندرونو ترل

جي د بلاكيد د سولي د وخت به نوم ياديوي.

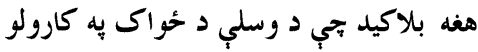

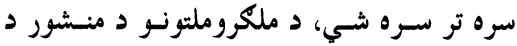

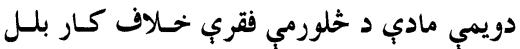
كيري. غج اخيسـتل د سـولي او جكــــي يـه دوازور

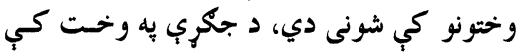

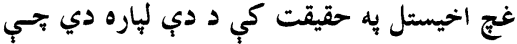

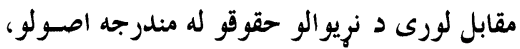

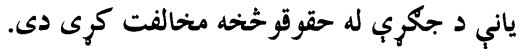

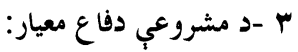

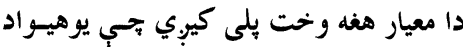

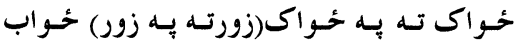

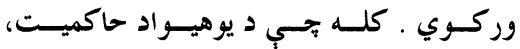

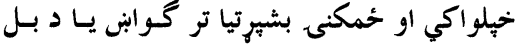

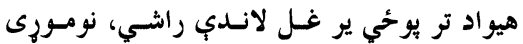

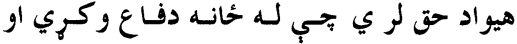

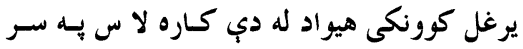

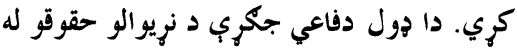

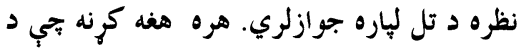

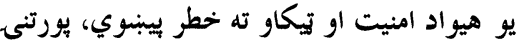

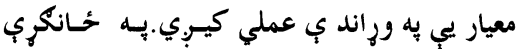
توكه كله جي دفاعي سيستم به كار وي.

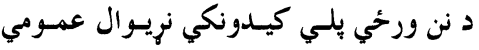

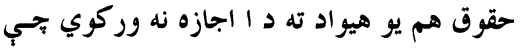

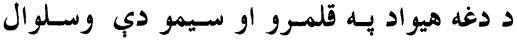

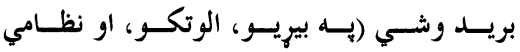

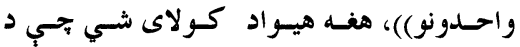

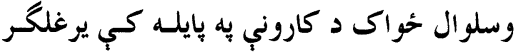

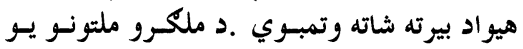

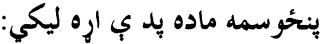

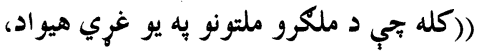

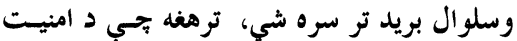



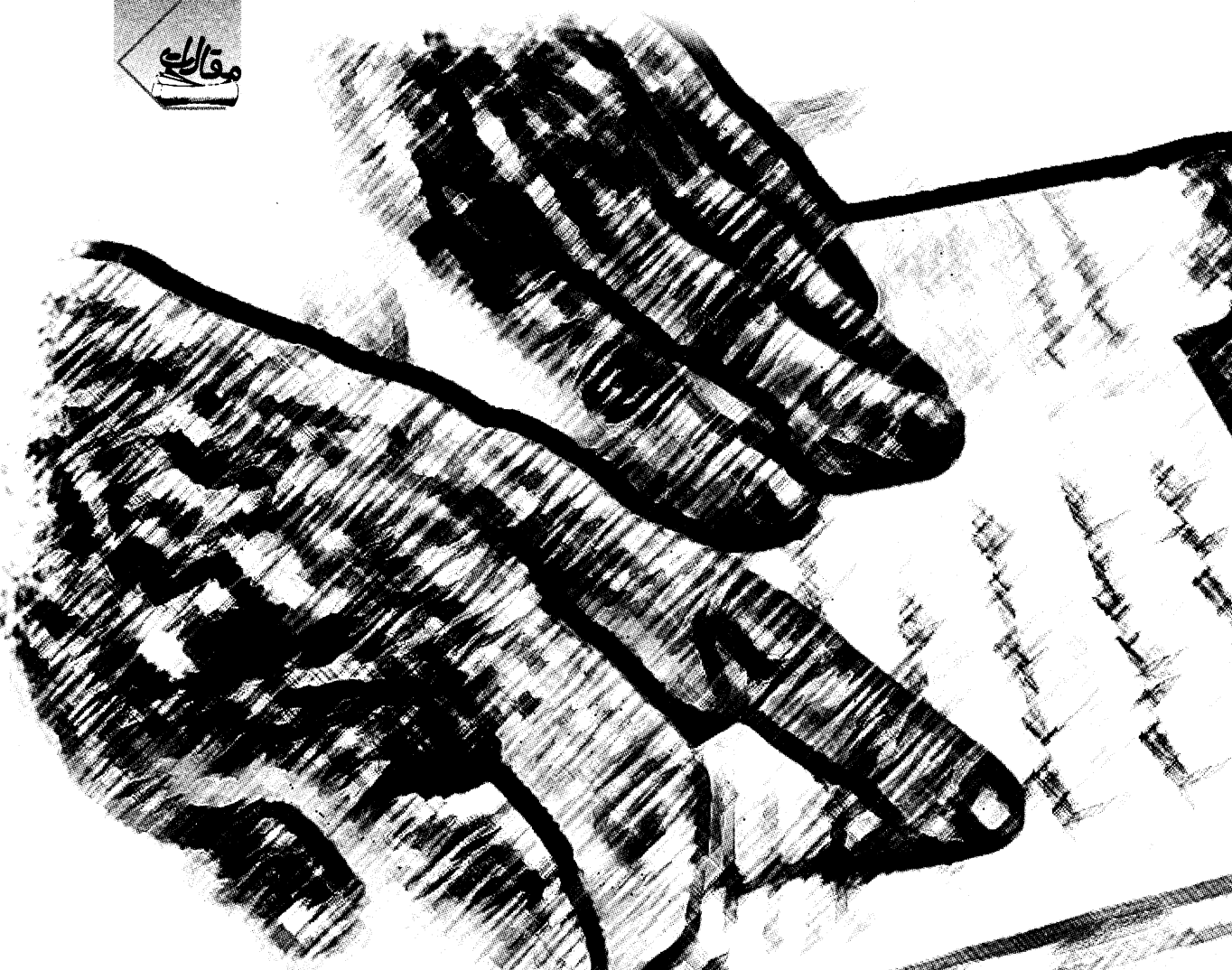

3
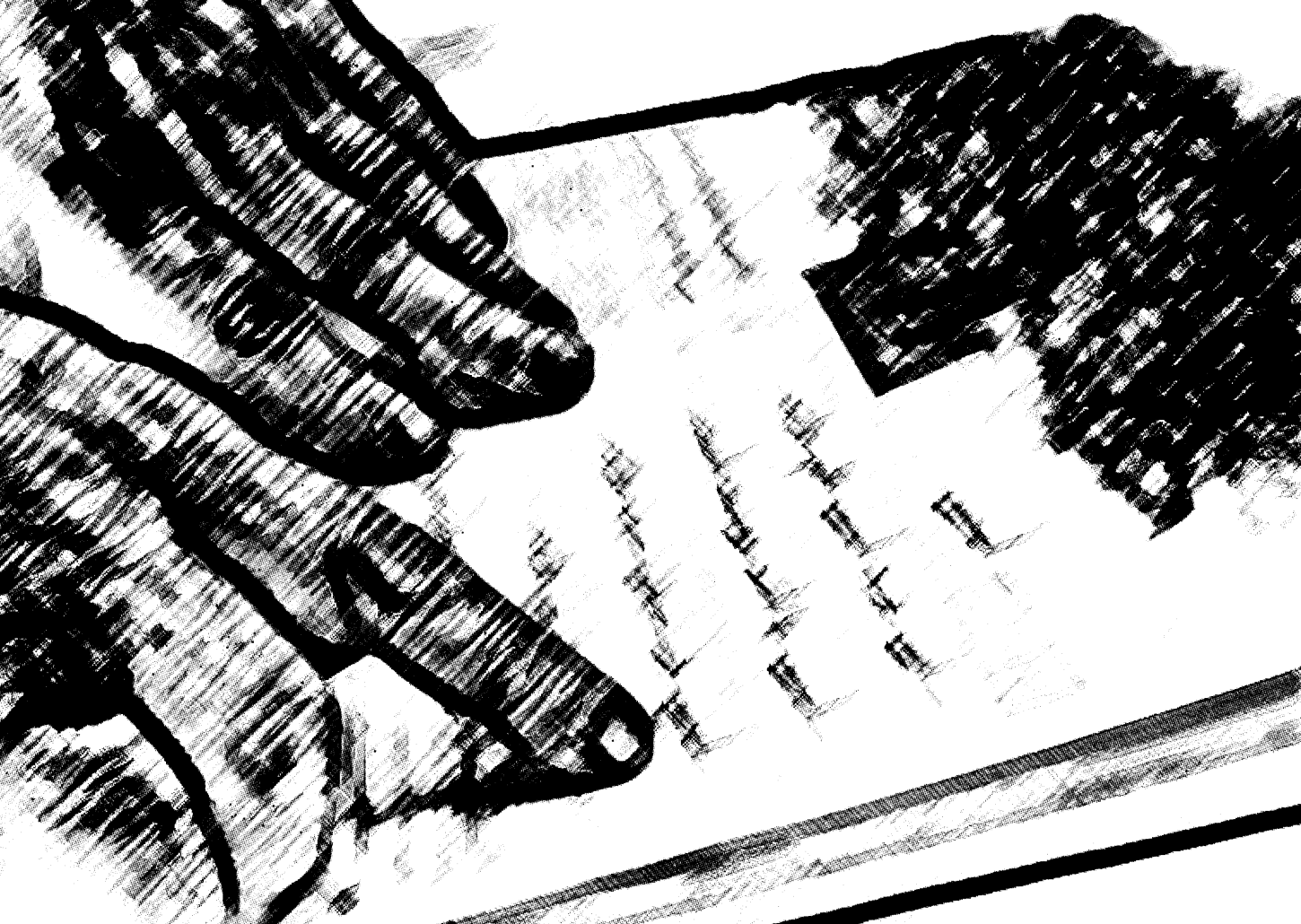

$5,2 \times 2,2)$

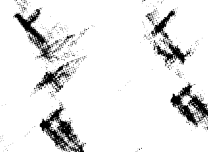

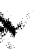

.
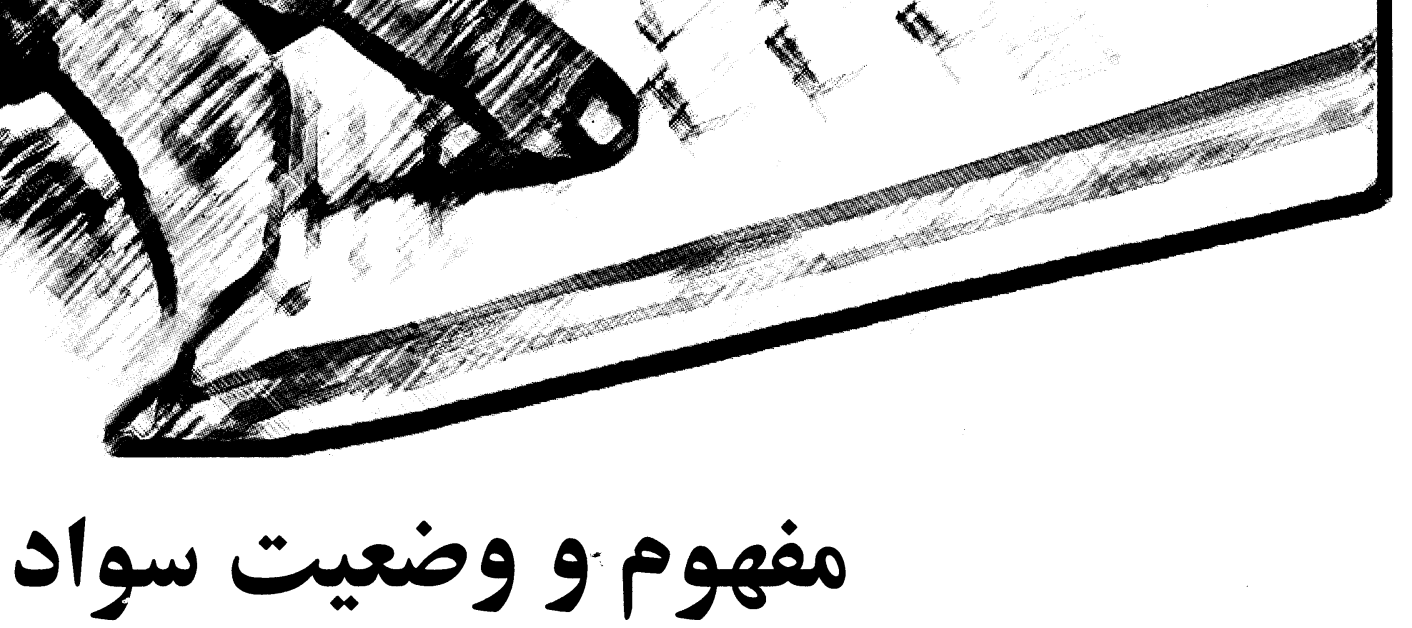

( به مناسبت روز جهانى سواد)

تقى واحدى روز

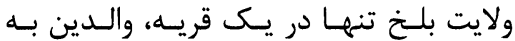

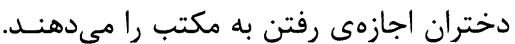

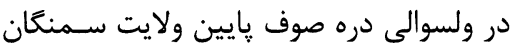
نيز وضع دختران بهتر الى از اين نيست ولايت

$$
\text { مفهوم وانواع سواد }
$$

سواد عبارت است از توانايى به رمز آوردن

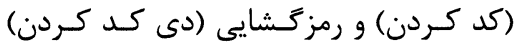

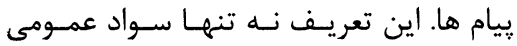

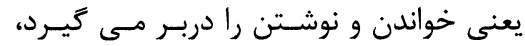

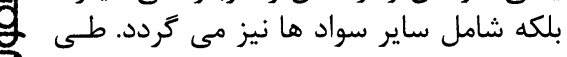

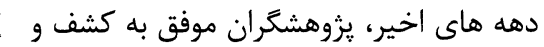

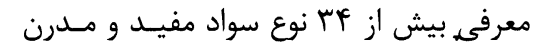

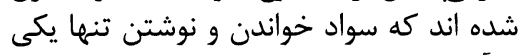

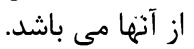

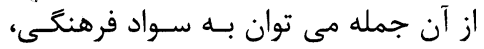

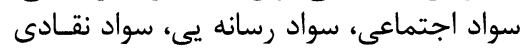

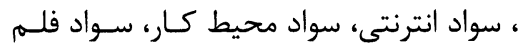
شناسى و سواد فناورى اشاره كرد كه هر يك

(iv
سازمان كه سواد را توانايى خواندن و نوشـتن

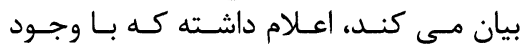

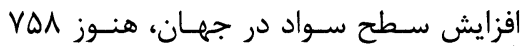

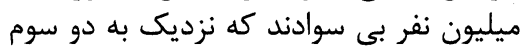

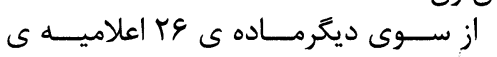

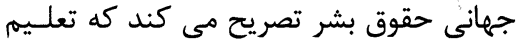

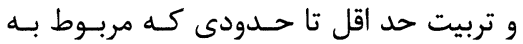
تعليمات ابتدايى و اساسى است بايد ريد رايكان و و

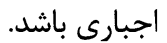

همينطور بيان مى كند كه تعليم و تربيت

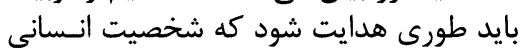

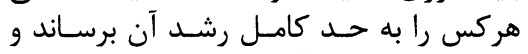

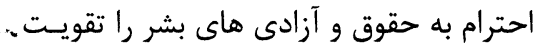
اما متأسفانه هنوز در بسيارى از نقاط دور دست كشور ما، آموختن سواد براي دئ دخت دئسران عيب شمرده مى شود. مثلا در ولسوالى كلدار
هفدهم سنبله برابر با هفتم ســـتامبر، روز

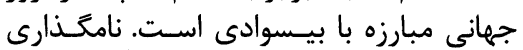

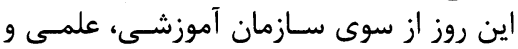

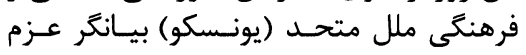

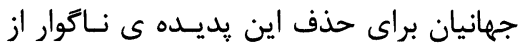
جامعه لى بشرى مى بـ باشد.

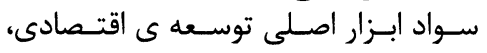

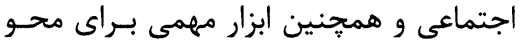

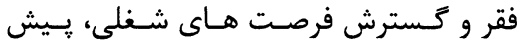

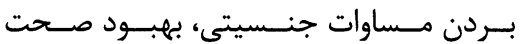
خانواده، حفاظت از محسيط زيستست و و تـرويج

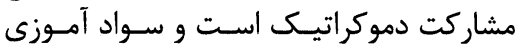

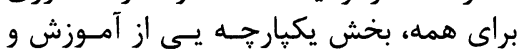

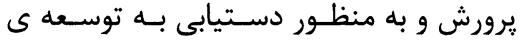
حقيقى و يايدار است.

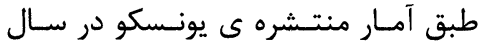

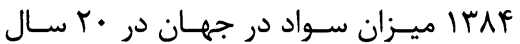

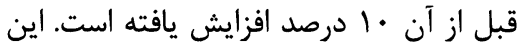


نامتعارف و غير سـنتى در است. وضعيت سواد در افغانستان

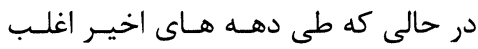

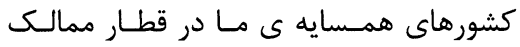

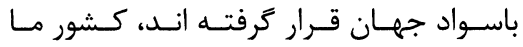

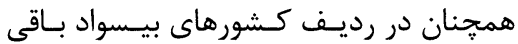

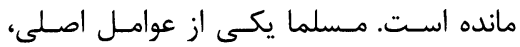

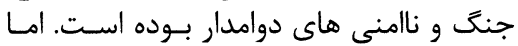

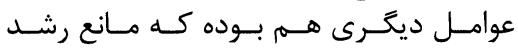

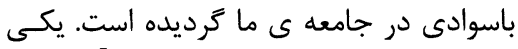

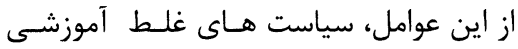
حكومت بوده است.

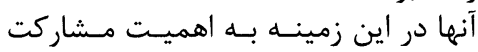

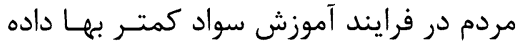

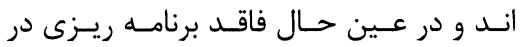

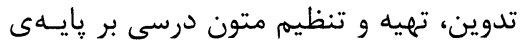

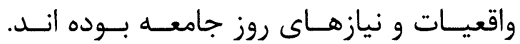

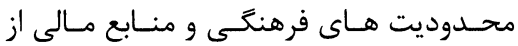

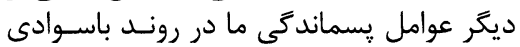
افراد جامعه بوده است.

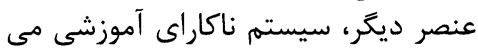
باشد. به طورى كه حداكثر توجه روى روى حافظئه آموزنه

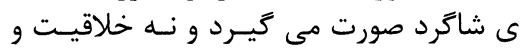

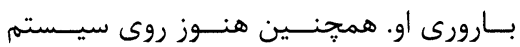

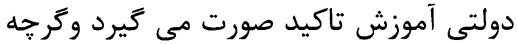

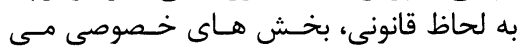
توانند جهت تاسيس مكاتب اقدام نمايند، اما

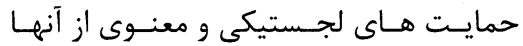
صورت نمى گيرد.

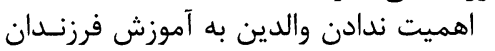

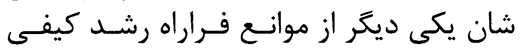

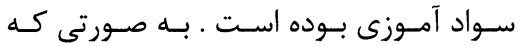

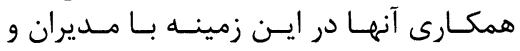

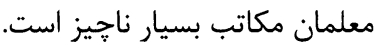

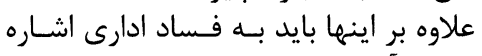

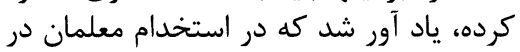
بسيارى موارد واسطه بر قانون ارجحيـت در داده مى شود. بى توجهى به نيازهاى مادى مادى معلمان نيـز

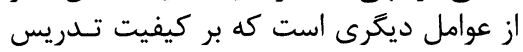
اثرات منفى داشته است دئرى الست فضاى نامناسب آموزشى، كمبود معلمان

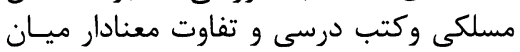

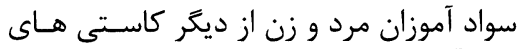

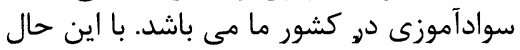

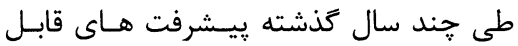

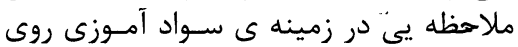

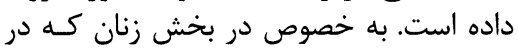
حذشته كمتر مجال آموختن سواد داشته اند ندان
انجام امور، قدرت انتخـاب

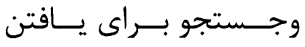
مشاغل يارى مسى رسـاند.

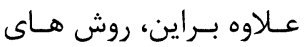

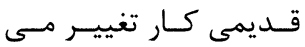
يابند، جرا كه سواد امكان

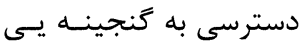

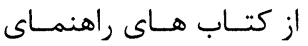
عملى را فراهم مى سازي سازد.

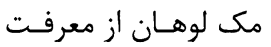
شناسى جديد جاي

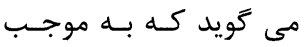
آن، فرد باسـواد، دانسش و ورئه

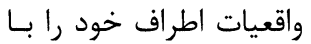

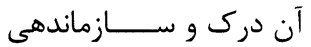

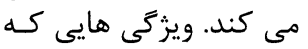
از داشتن سواد منتج مسى هـى

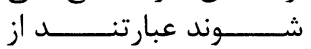

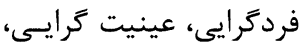

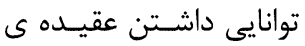

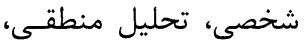

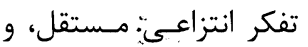
درك تاريخ.

\section{ســـوادآموزى در كــشورهاى توســـه \\ نيافته}

ارزيابى انتقادى نهادهاى مختلف آموزشى نئ نياف

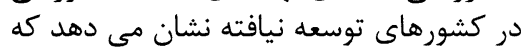

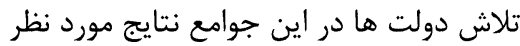

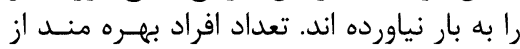

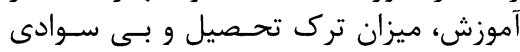

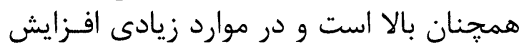

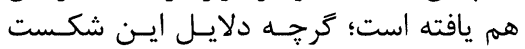

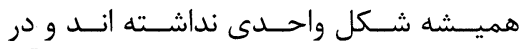

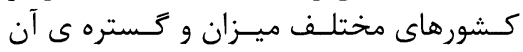

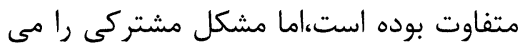

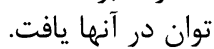

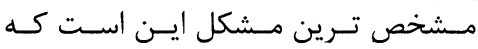

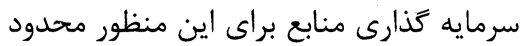

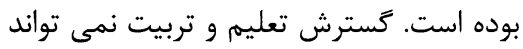

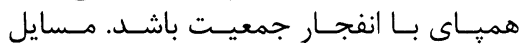

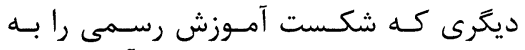

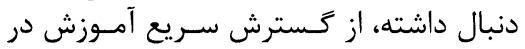

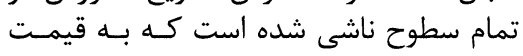
فدا كردن كيفيت انجاميده است

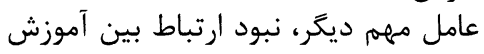

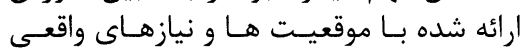

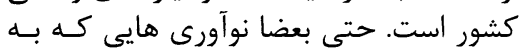

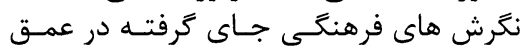

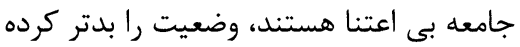

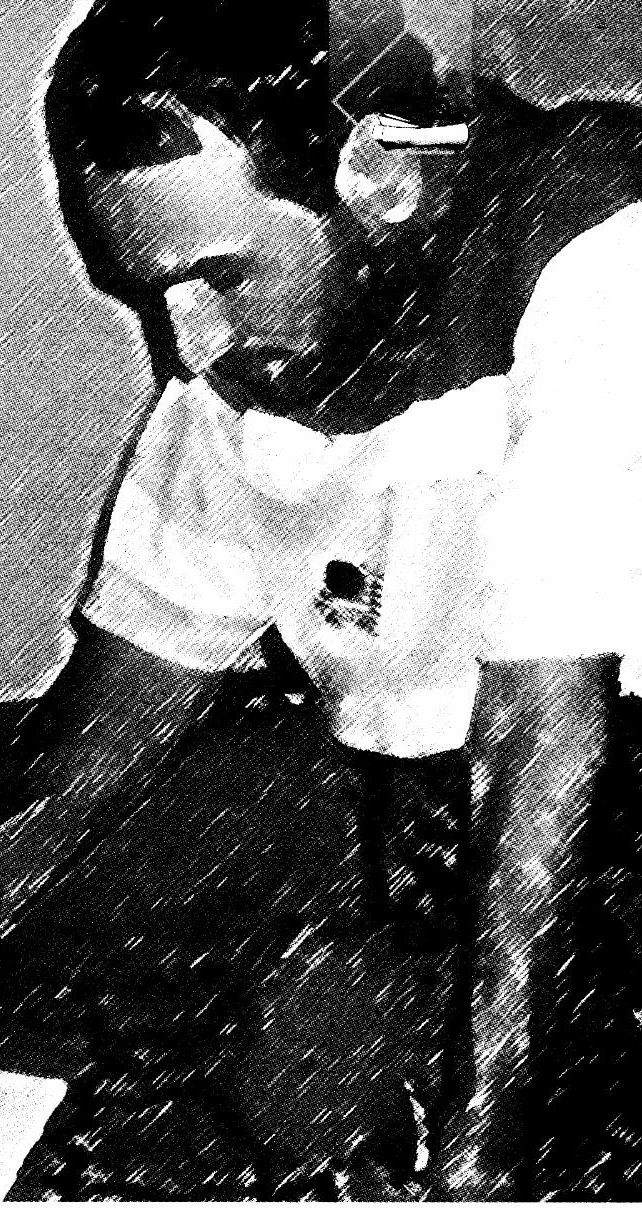

تعريف، اسـتندردها و راهكارهـاى توسـعلى إى خاص خود را دارند.

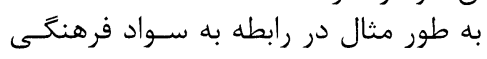

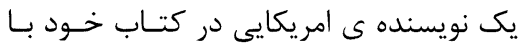

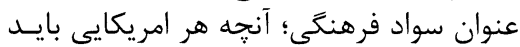

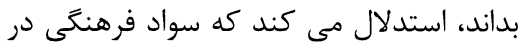

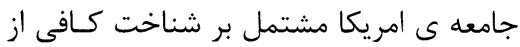

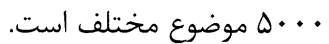

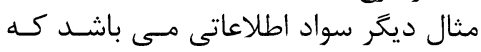

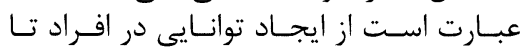

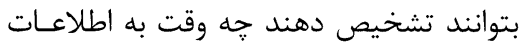

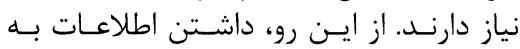

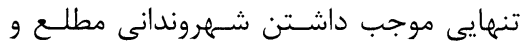

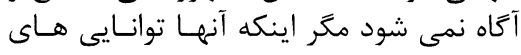

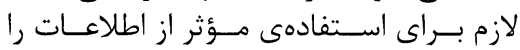
كسب كرده باشند.

\section{سواد و توسعه}

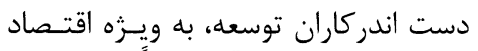

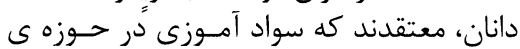

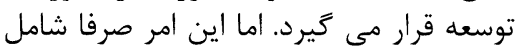

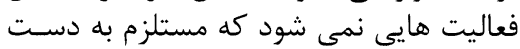

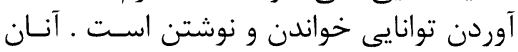

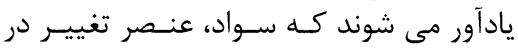

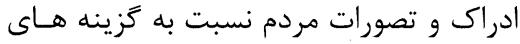

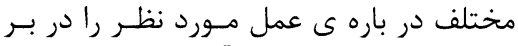

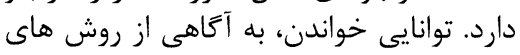


r _ د عقيدي آزادي هم، د انسان د طبيعي

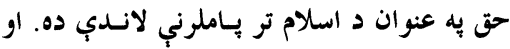

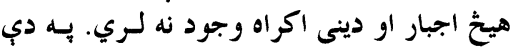

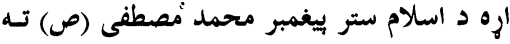

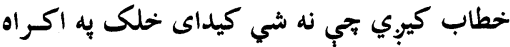

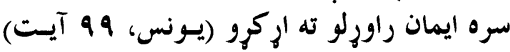

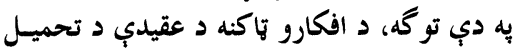

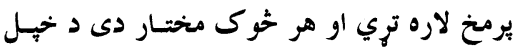

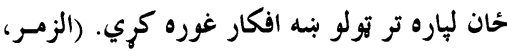

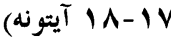

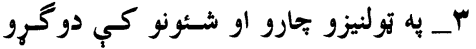

برابري، د اصولوله مخي د اسلام د مننسي وردهـ

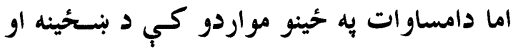

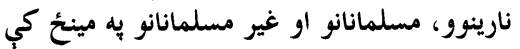
نه ستر گو كيوي.

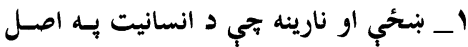

كي يو له بل سره برابر دي (النسا لومي ارئه آيست)

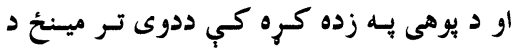

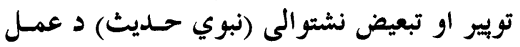

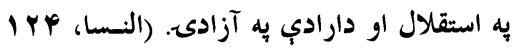

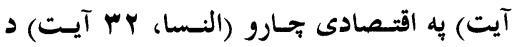

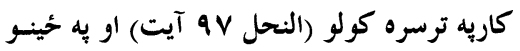

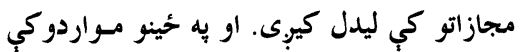

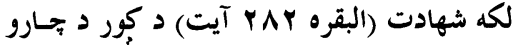

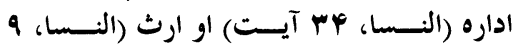

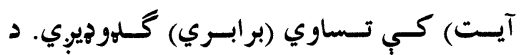

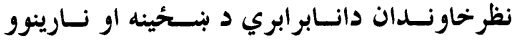

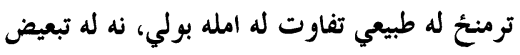

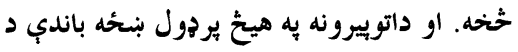

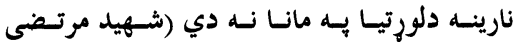
مطهرى، نظام حقـوق زن در اسـلام، انتسشارات

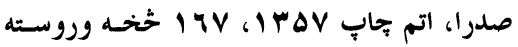

مخونه)

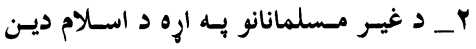

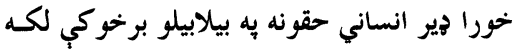

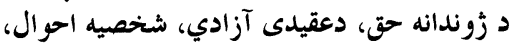

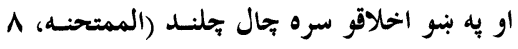

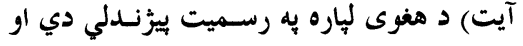

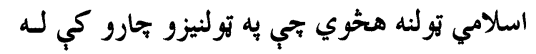

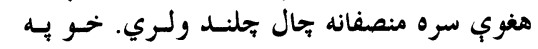

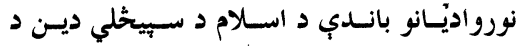

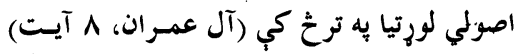

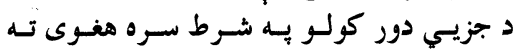

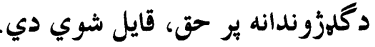

سـره مسساوى دي. 》النساس امسام الحسق سـواء كاسنان المشطه (نبوي حديث) لماوى دان

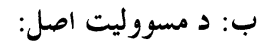
د انسسانانو اجتمساعي كيدنسه انسساني متقابـل

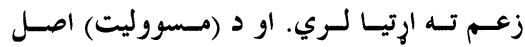

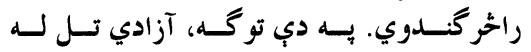

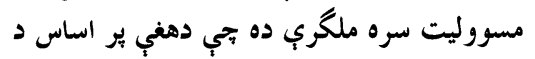

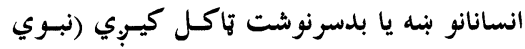

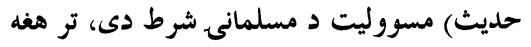

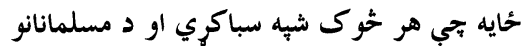

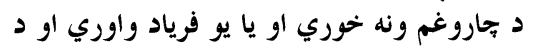

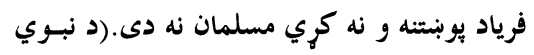

حديث) بــه دي مراتبـو برسـيره، اســلامى متقابــل مسووليت ددى غوبنتنه كوي تحى بـ مسلمانان بايد

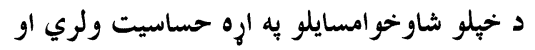
د تولني د سالمى جوروني او خيرته د د بلني ليـاره

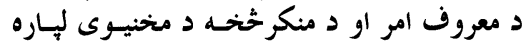

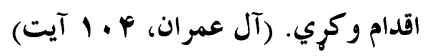

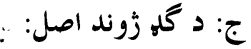

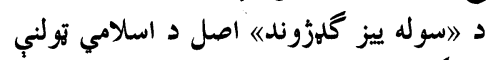

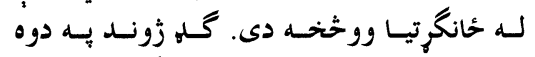

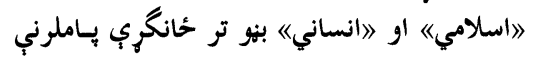

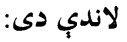

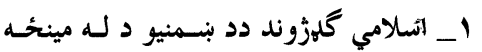

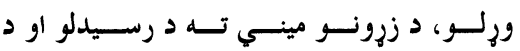
ورور گلوى د اصل د تينگبنـت سياربنته كوري.

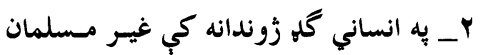

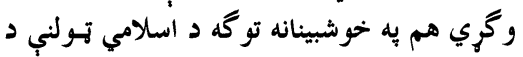

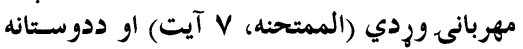

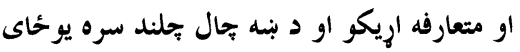
د ارشادي اريكو خخه برخمن دي.

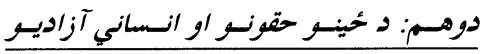

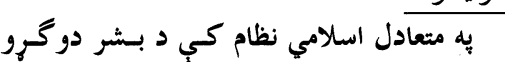

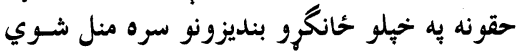

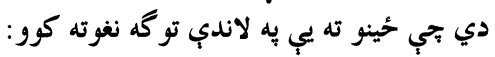

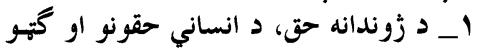

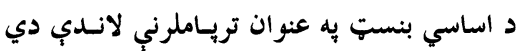

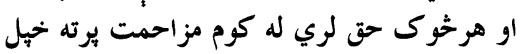

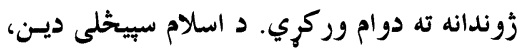

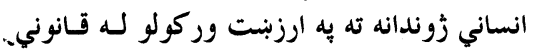

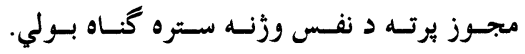

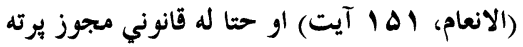

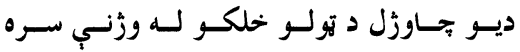

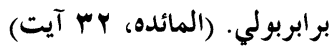

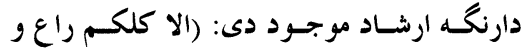

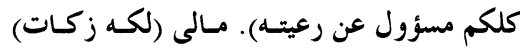

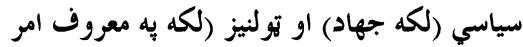

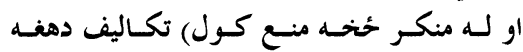

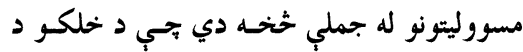

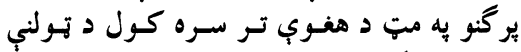
دوام او تينگبنت راولي.

تولنيزي إيكي او بشري حقونه:

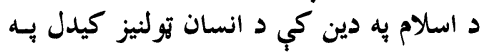

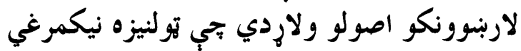

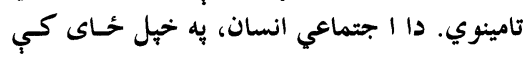

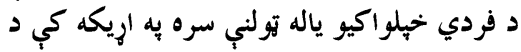
حقونو خاوند هم دى. لومرى: ير تولنيزو اريكو واكمن اصون إنول:

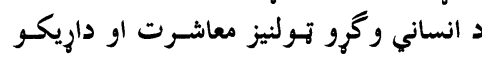

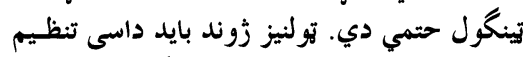

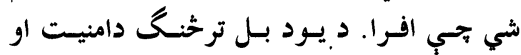
هوساينى احساس وكري.

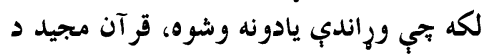

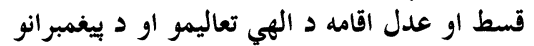

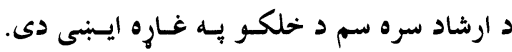

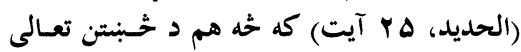

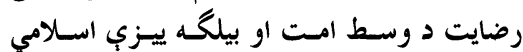

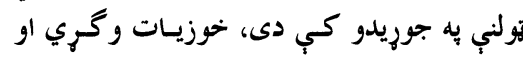

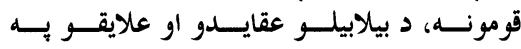

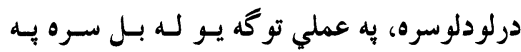

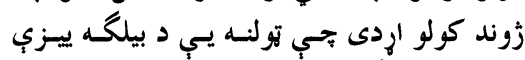

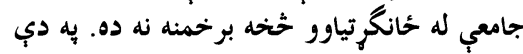

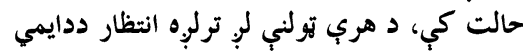

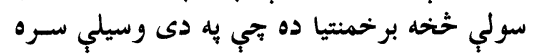

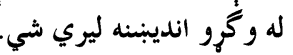
د اسلام دين، ددي نظر به تامين كي دي دئه دريسو اساسي اصولو به واكمنى تينگگارلوي. الف: د مساو ات اصل اصل د مساوات اصل يه كوجنيو او لويوتولنو كي اصي و كلهزوندانه بنست كنبل كيري.

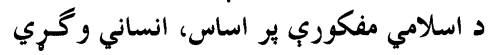

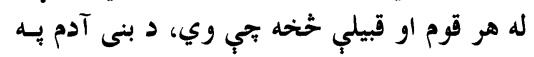

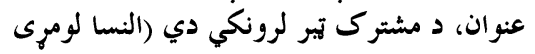
آيت

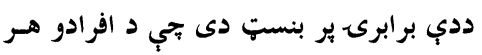

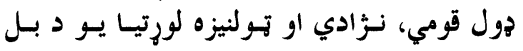
يوري تهلي ده.

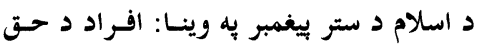

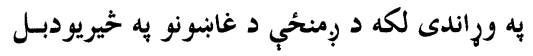


كوتفريد ايفراهيم لسينگ، از متفكران عسر

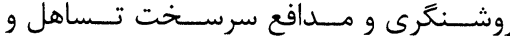
روادارى و آزادى اديان و انديشه.

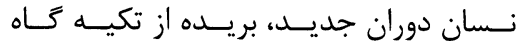

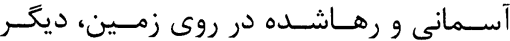

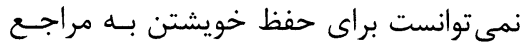

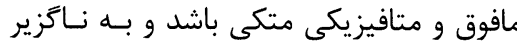

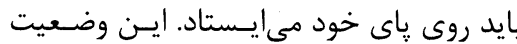

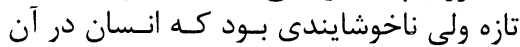

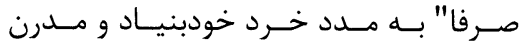

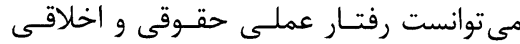

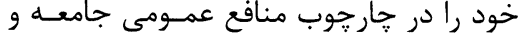

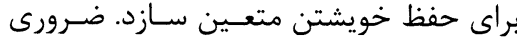

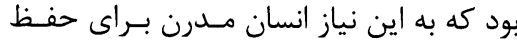

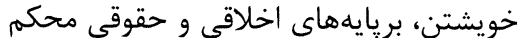

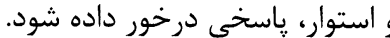

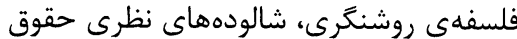

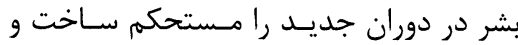

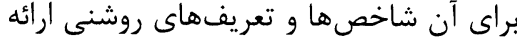

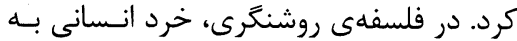

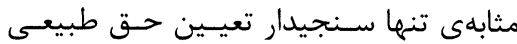

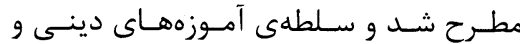

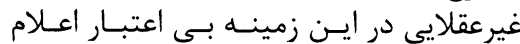

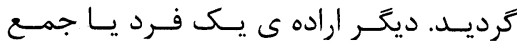

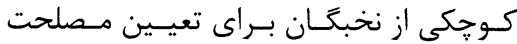

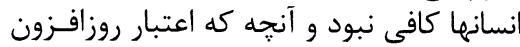

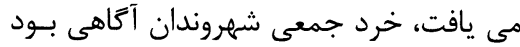

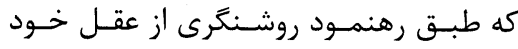

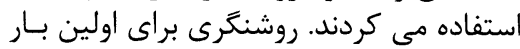

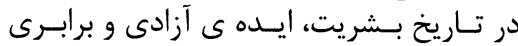

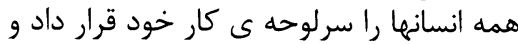

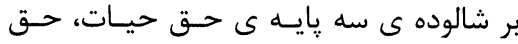

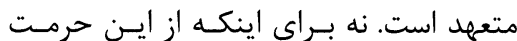

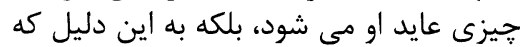

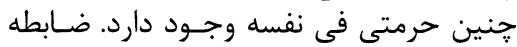

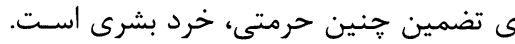

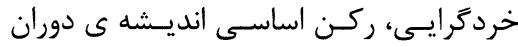

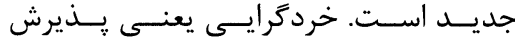

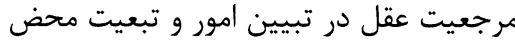

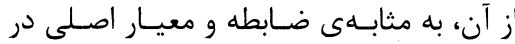

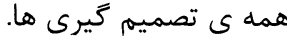

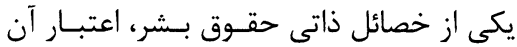

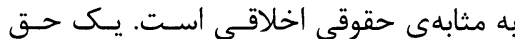

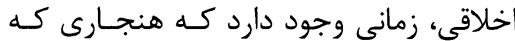

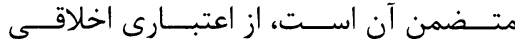

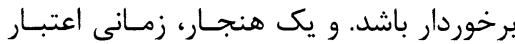

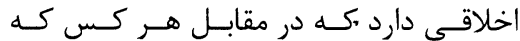

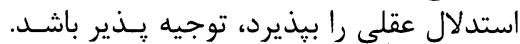

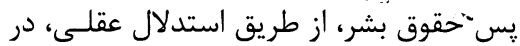

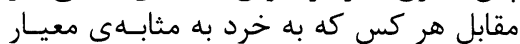
ارزيابى و ارزشكذارى تمكين كند، قابل دفـاع مناع

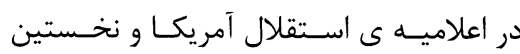

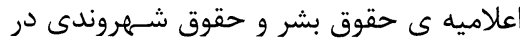

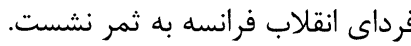

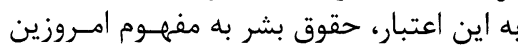

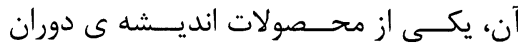

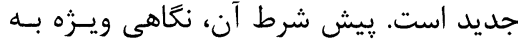

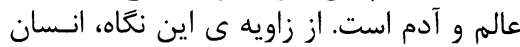

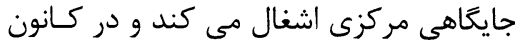

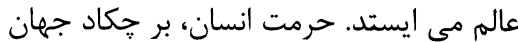
قرار مي كيرد. كنش اخلاقي او، ناشى انس از ايده

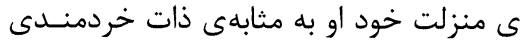

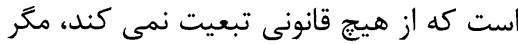

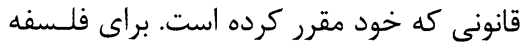

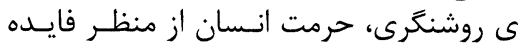

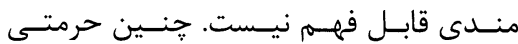

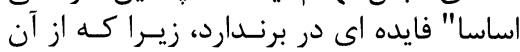

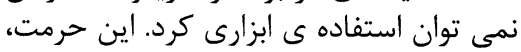

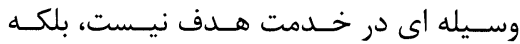

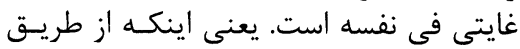

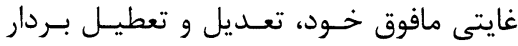

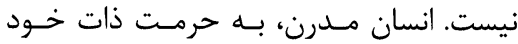

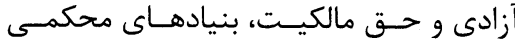

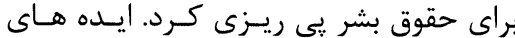

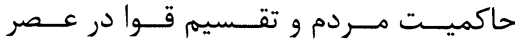

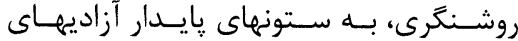

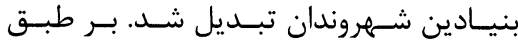

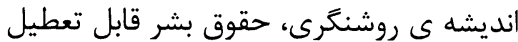

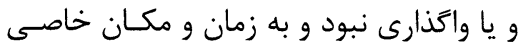

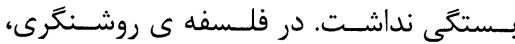

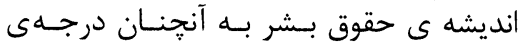

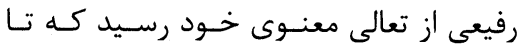

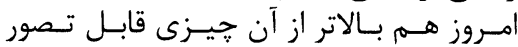

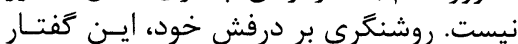

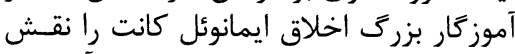

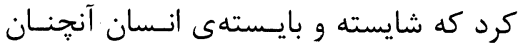

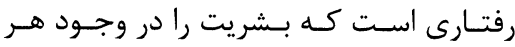

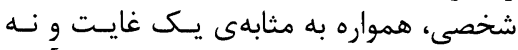

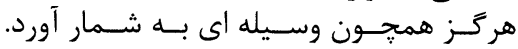

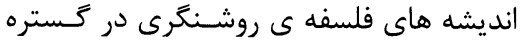

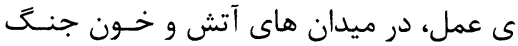

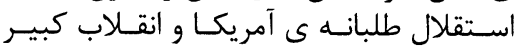

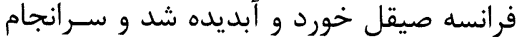


اقتصادى، اجتمـاعى و فرهنخسي و كنوانسيون

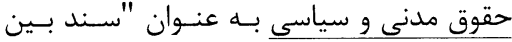

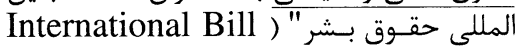

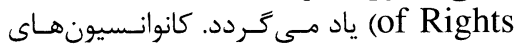

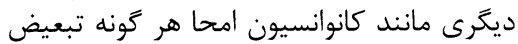

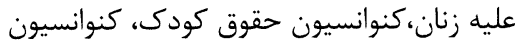

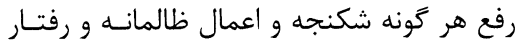

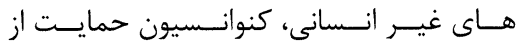

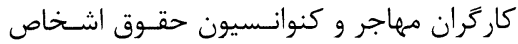

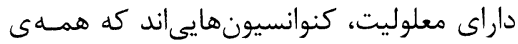
شان بر كرفته از مفاد "سند بين المللى حقـوق هـئ

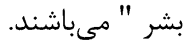
از نكاه ساختارى، هر دو كنوانسيون حقـوق

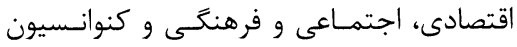

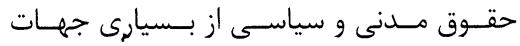

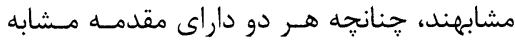

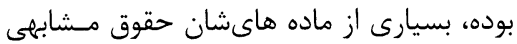

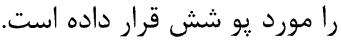

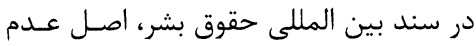

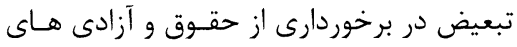

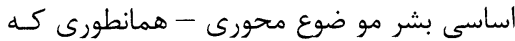

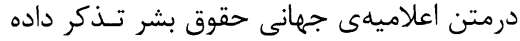

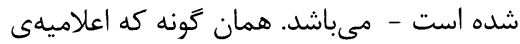

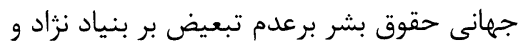

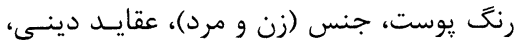

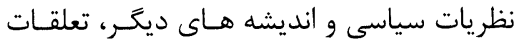

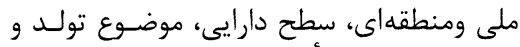

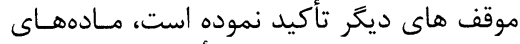

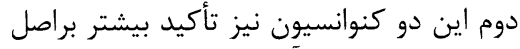

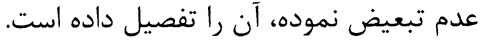

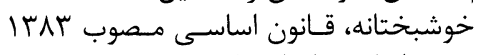

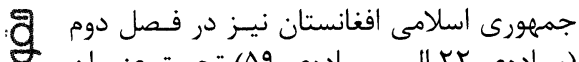

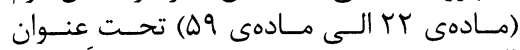
"حقوق اساسى و وجايب اتباع"، تقريباً تمامى إنى

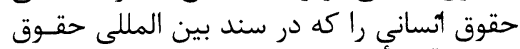

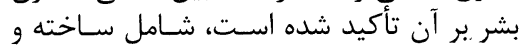

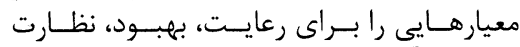

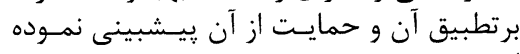

ملل متحد، جهت ابراز نظر فرسـتاد. مسسودىى

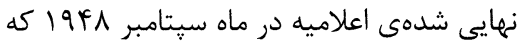

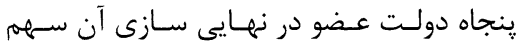

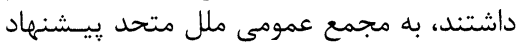

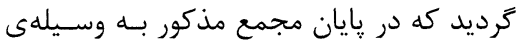

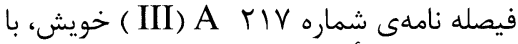

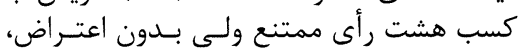

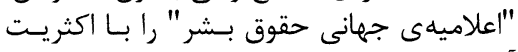

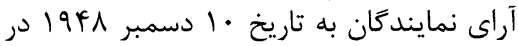
شهر ياريس تصويب نمودي.

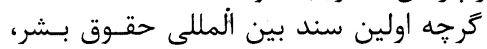

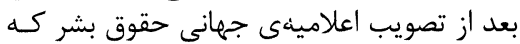

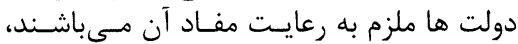

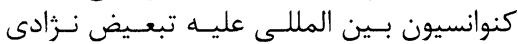

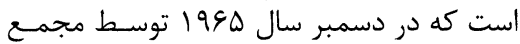

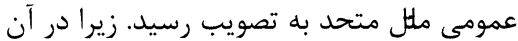

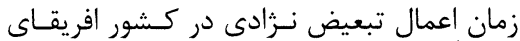

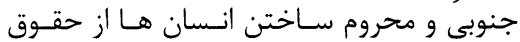

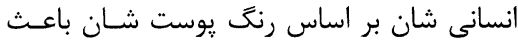

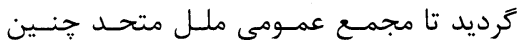

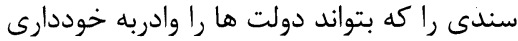

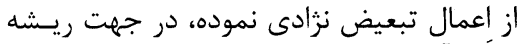

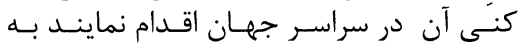

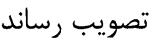

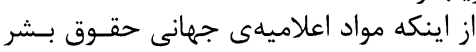

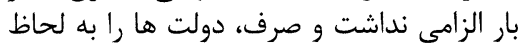

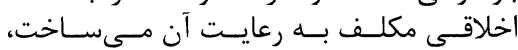

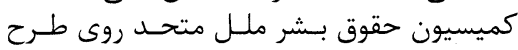

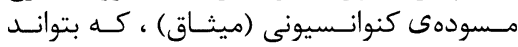

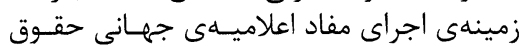

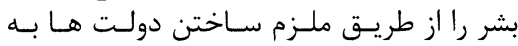

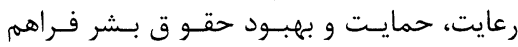

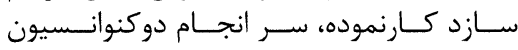

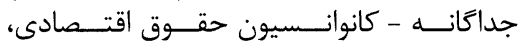

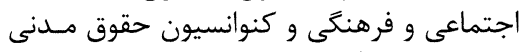

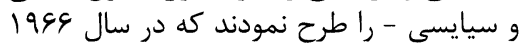

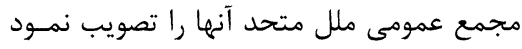

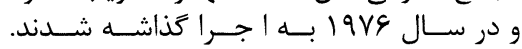

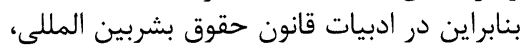

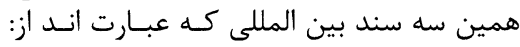
اعلاميهى جهانى حقوق بشر، كنوانسيون حقوق المئ ارن
"سند بــين الملــى حقــوق بـشر "

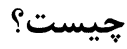
مصيبت هاى بزرى و و دلخراش به جا ماند

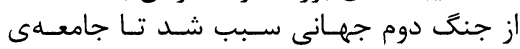

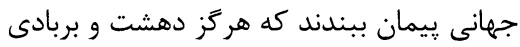

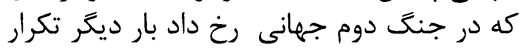

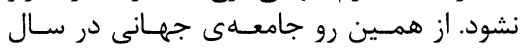

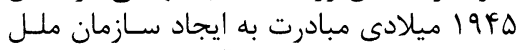

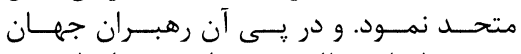

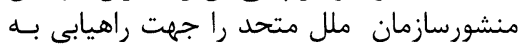
تضمين برخوردارى هر فرد از حقوقش ران ران ادر هر هر

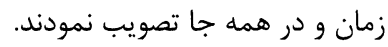

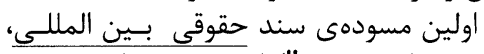

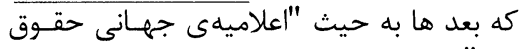

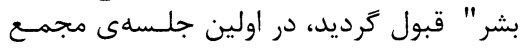

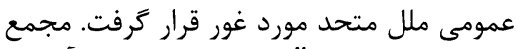

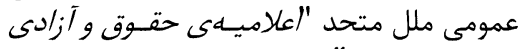

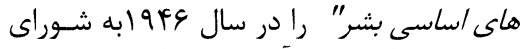

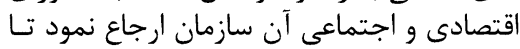

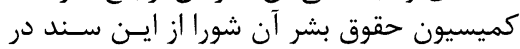

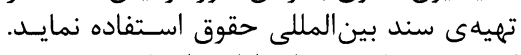

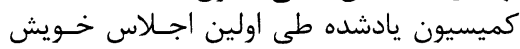

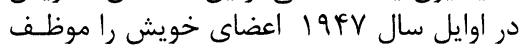

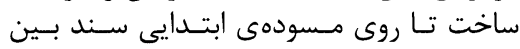

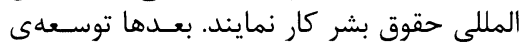

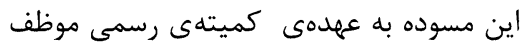

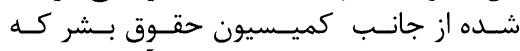
متشكل از هشت نفر از دول دول عضو آن آن كميسيون

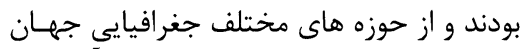

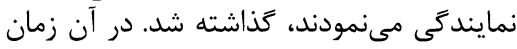

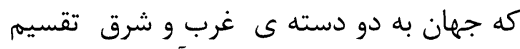
شده بود، انجام اين وظيفه كار آسانى نبودي

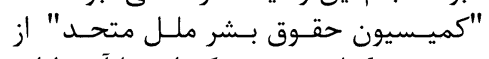

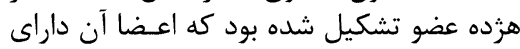

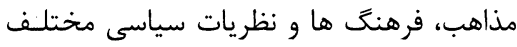

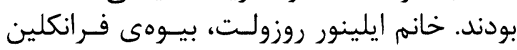

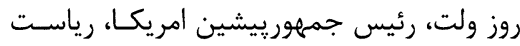

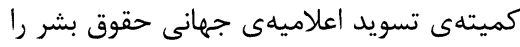

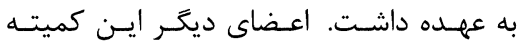



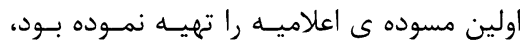


كميته، آقاى ينَ

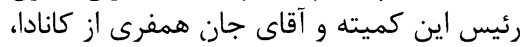

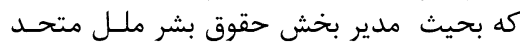

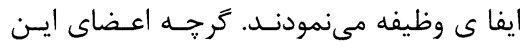

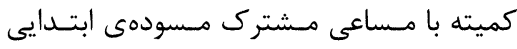

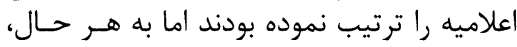
خانم روزولت در تصويب اعلاميه نقش بـ بـالقوه و وردال

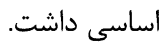

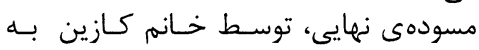

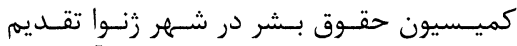

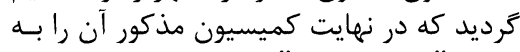
عنوان "مسودهى رنوا" به تمام دولت هائ عضون آن ران 
د كتو بلي كولو ته داسي زمينه برابره كري،يجي

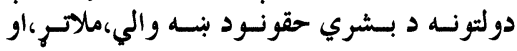

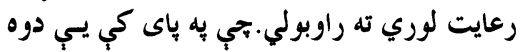

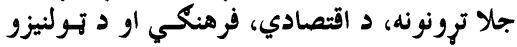

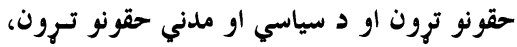

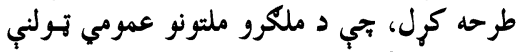

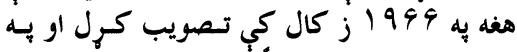
199V 199

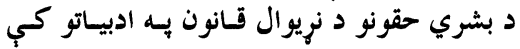

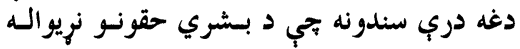

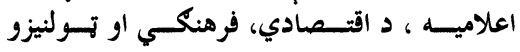

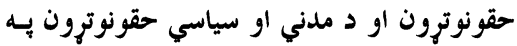

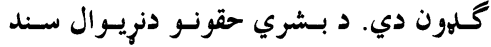
(international bill of rights)

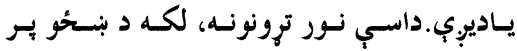

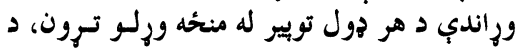

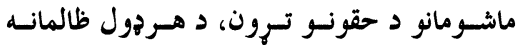

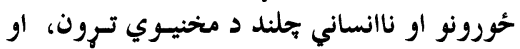

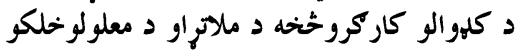

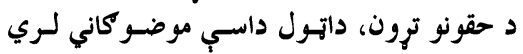

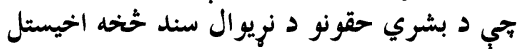

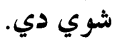

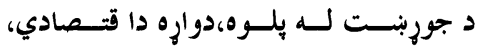

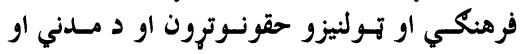

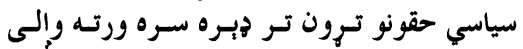

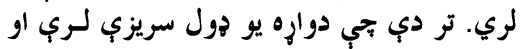

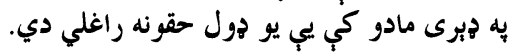

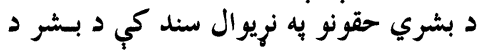

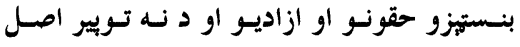

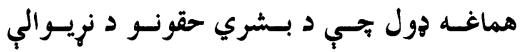

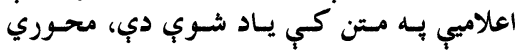

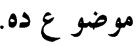

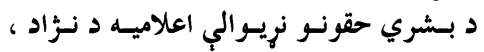

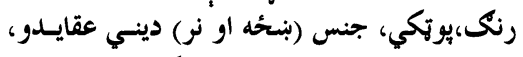

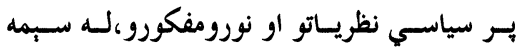

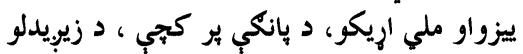

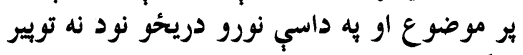

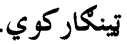

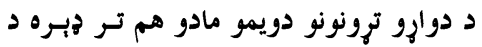

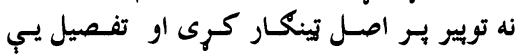

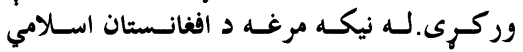

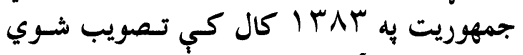

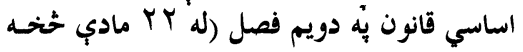

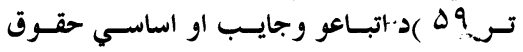

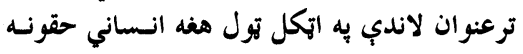

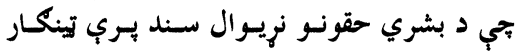

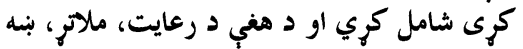

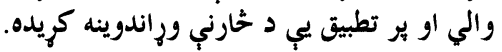

\section{د بشري حقونودزده كري دلري خلورم لوست دبشري حقونو نزيوال سندخه شى دى دي؟}

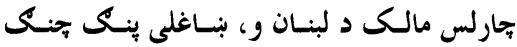

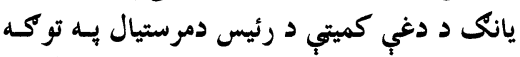

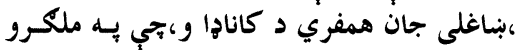

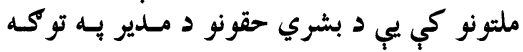

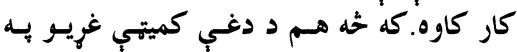

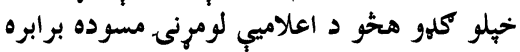

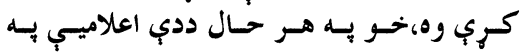

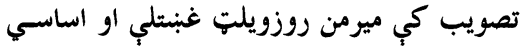

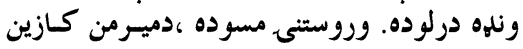

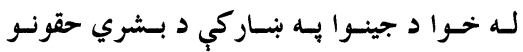

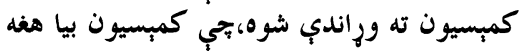

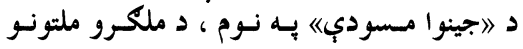

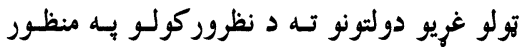

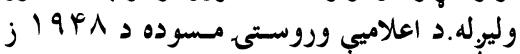

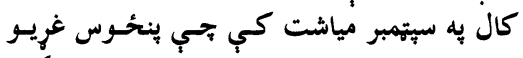

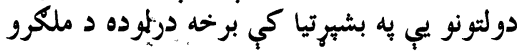

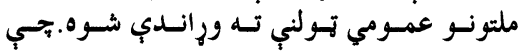

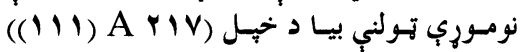

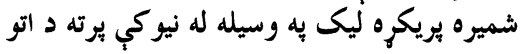

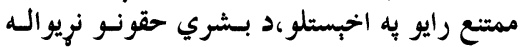

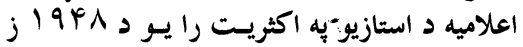

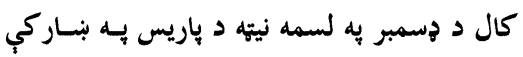
تصويب كره.

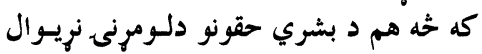

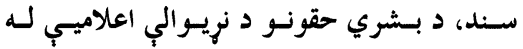

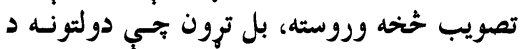

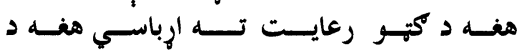

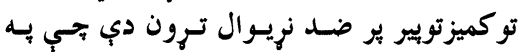

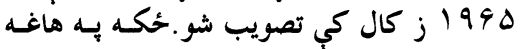

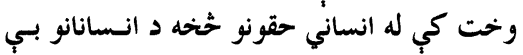

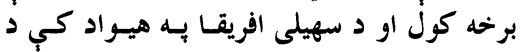

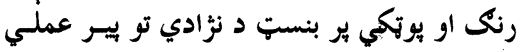

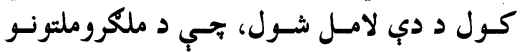

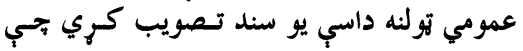

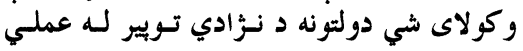

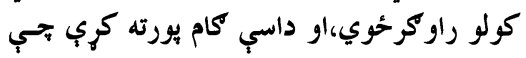

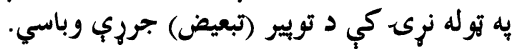

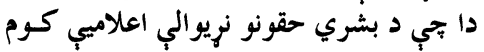

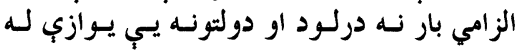

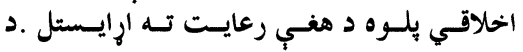

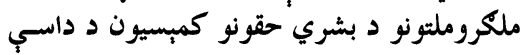

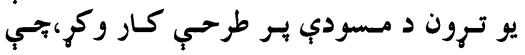
وكولاى شي د بشري حقونو د نريوالي اعلاميسي

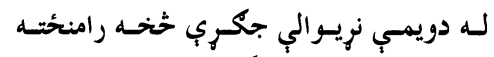

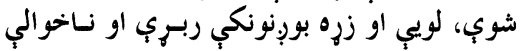

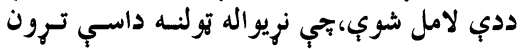

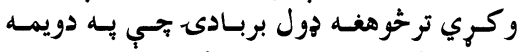

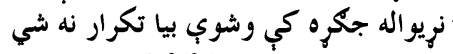

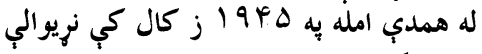

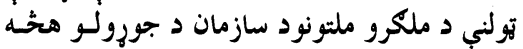

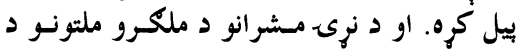

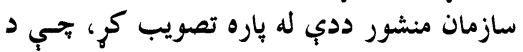

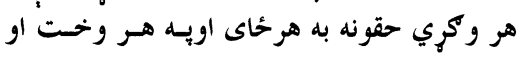
زمان كي تضمين شي.

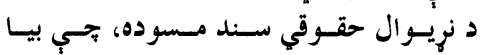

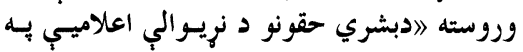

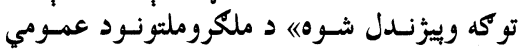

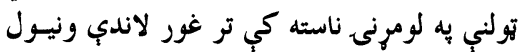

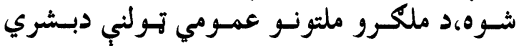

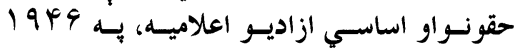

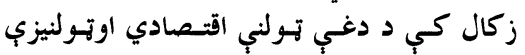

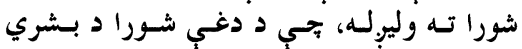

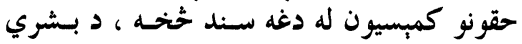

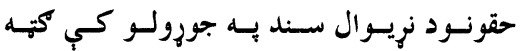

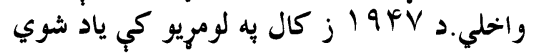

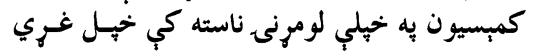

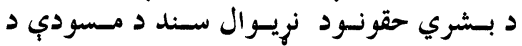

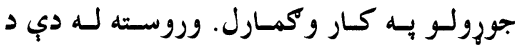

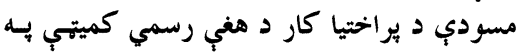

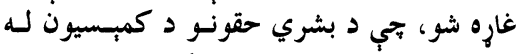

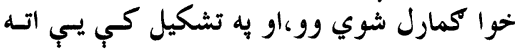

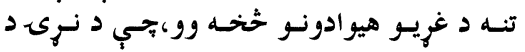
ببلاببلو سبمو خخه يب استازيتوب كاونه

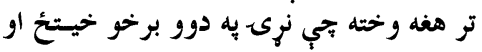

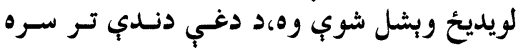

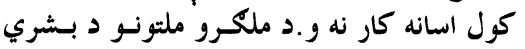

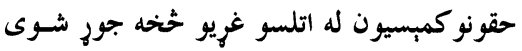

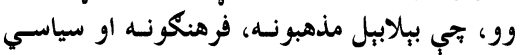
نظريات يب درلودل

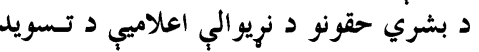

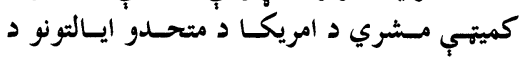

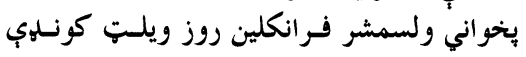

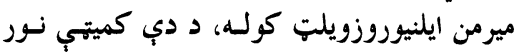

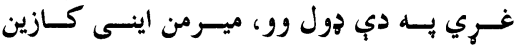

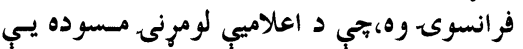
تياره كري وه، دُ دغي كميتهي رايسورتر بنساغلى لوني 


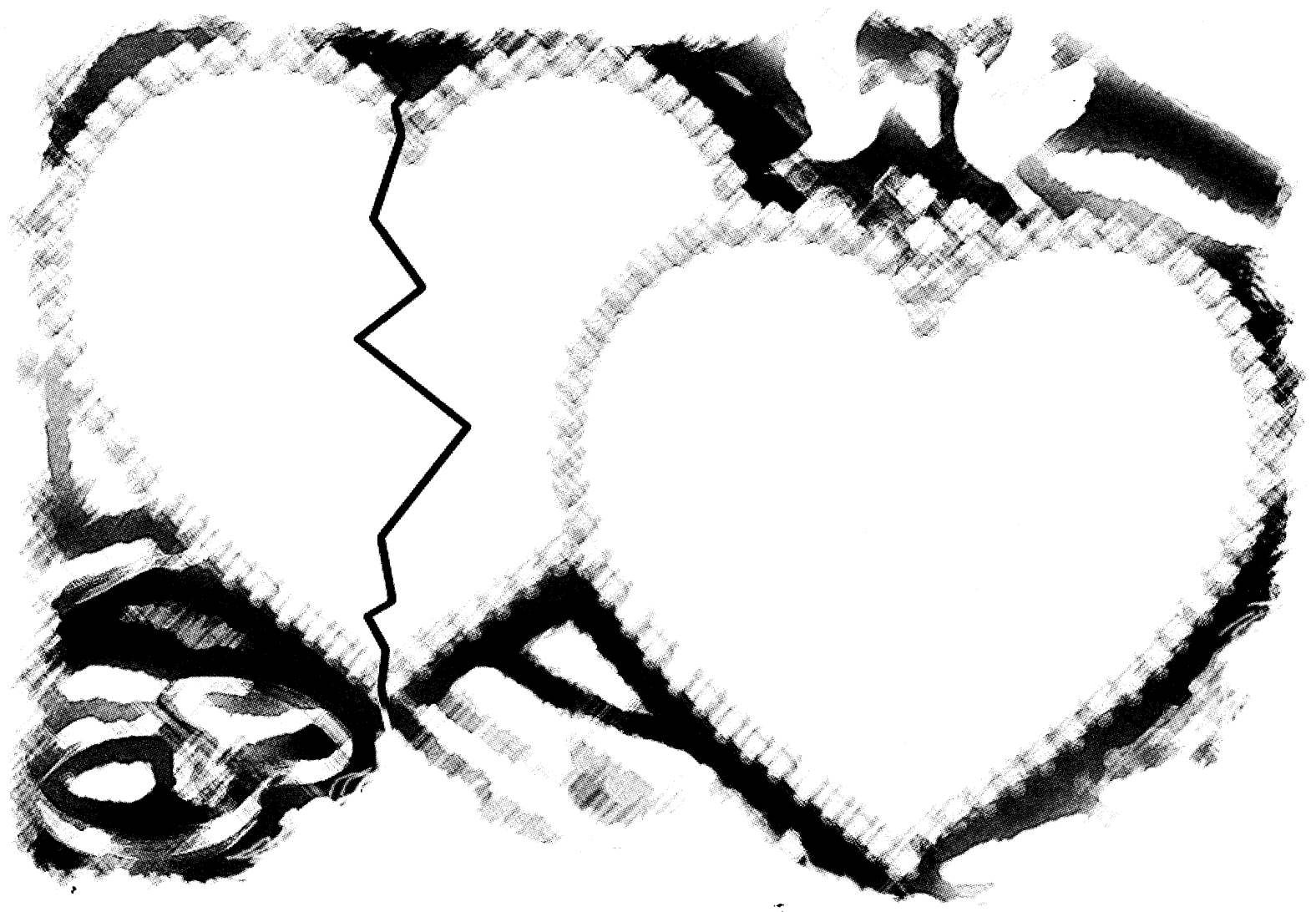

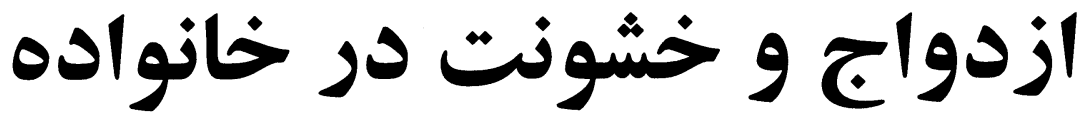 \\ سر محقق، فضل احمد غروب}

مدرسه مى آموزند هيجگًاه فراموش نمى كنند.

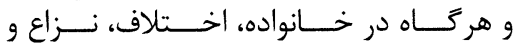

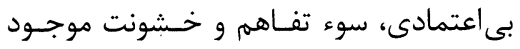

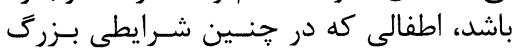

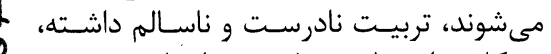
录

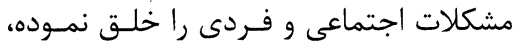

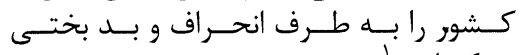
مى كشانند.'

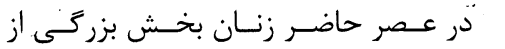

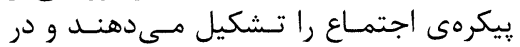

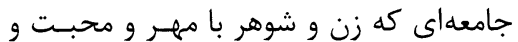

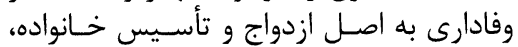

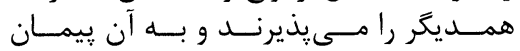

امروز در سلامت كودكـان صـالح و كودكـان

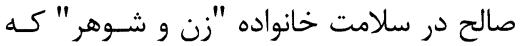

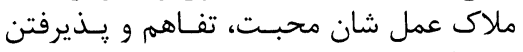

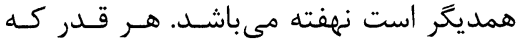
روابط زن و شوهر نيك، صـميمى و و دوسـتانه

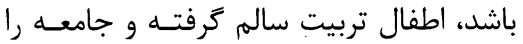

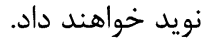

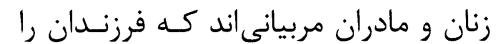

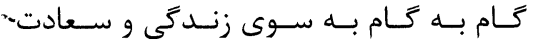

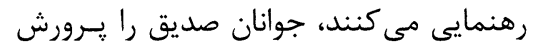

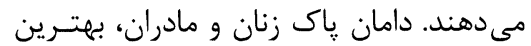

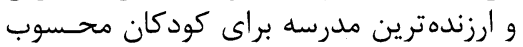

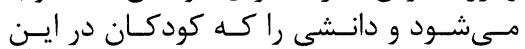

واضح است كه خانواده به عنوان نخستين

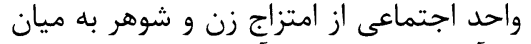

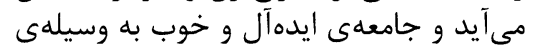

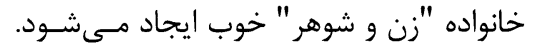
زن و شوهر اولين بناى جامعهداند و ائن اين دو در

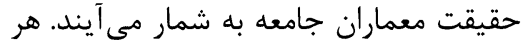

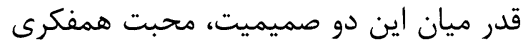

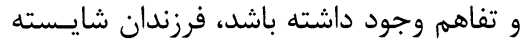

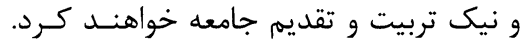

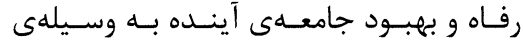

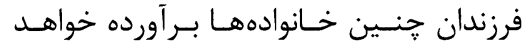

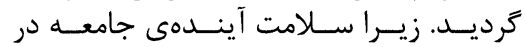

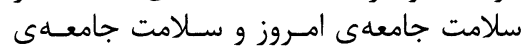




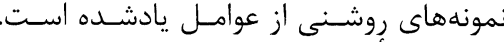

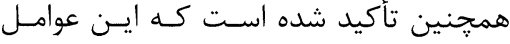

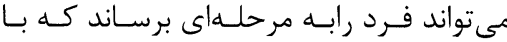

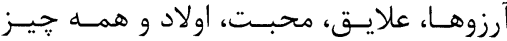

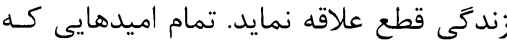

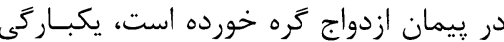

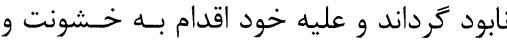

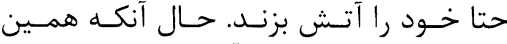

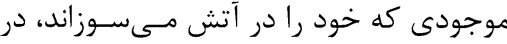

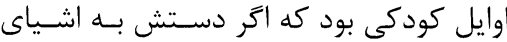

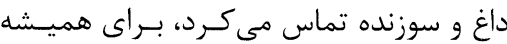

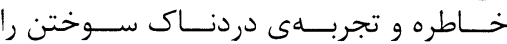

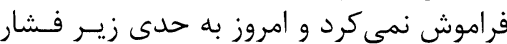

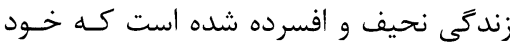

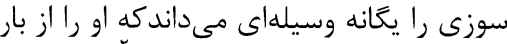

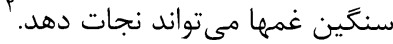

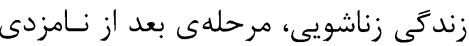

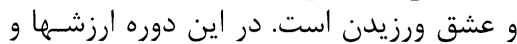

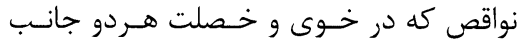

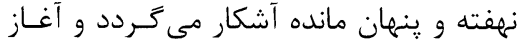

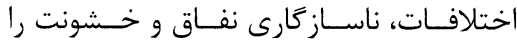

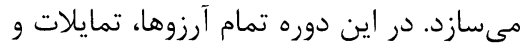

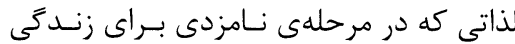

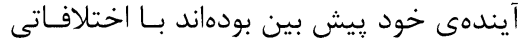

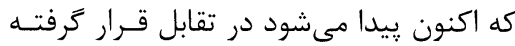

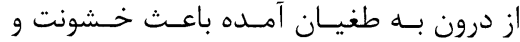

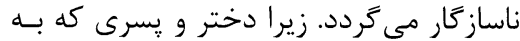

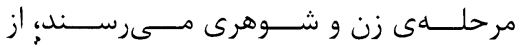

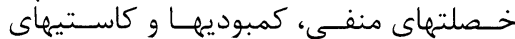

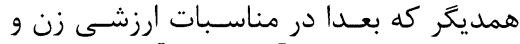

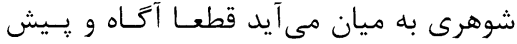

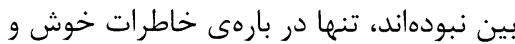

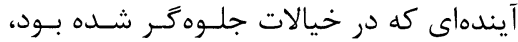

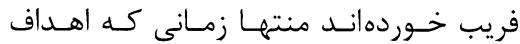

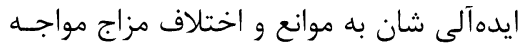

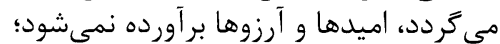

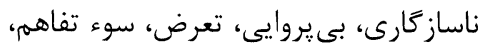

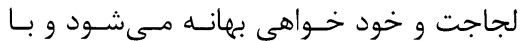

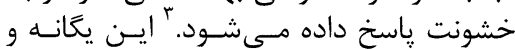

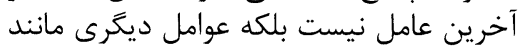

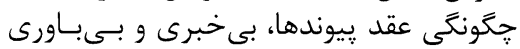

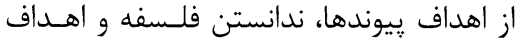

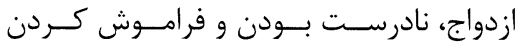

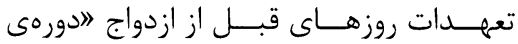

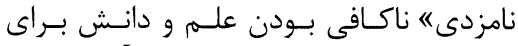

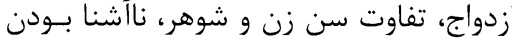

عمركردهاى نادرست فردى و اجتماعى همان

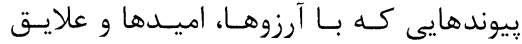

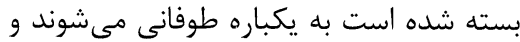

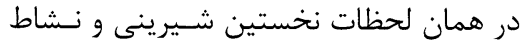

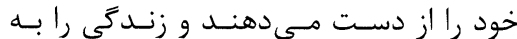
كابوس وحشتناكى تبديل ميى سازند. در اثـر

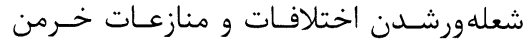

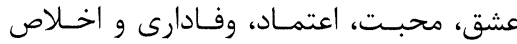

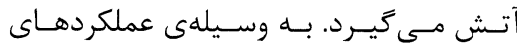

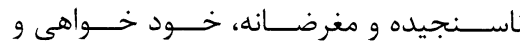

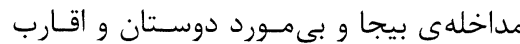

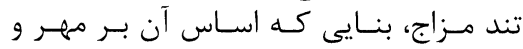

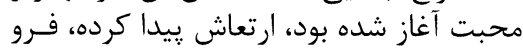

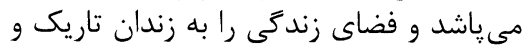

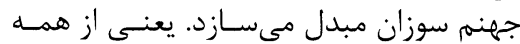

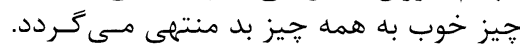

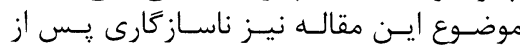
ازدواجها باوجودى كه به اميدها و آرزوهـا

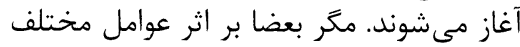

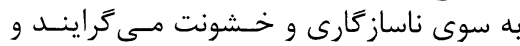

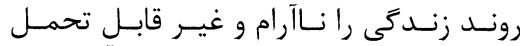

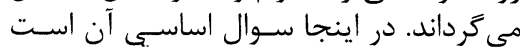

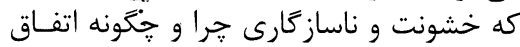

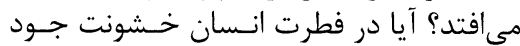

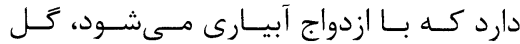

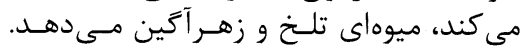

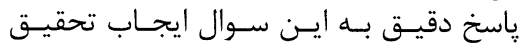

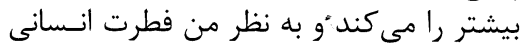

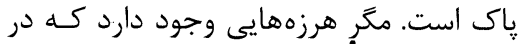

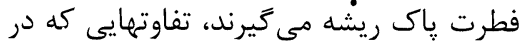

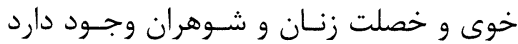

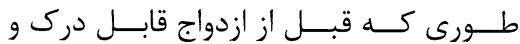

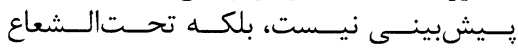

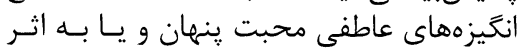

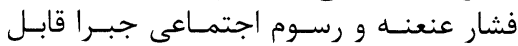

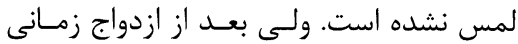

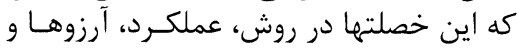

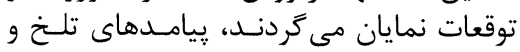

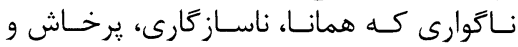

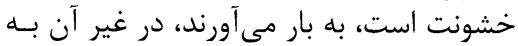

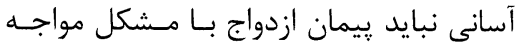

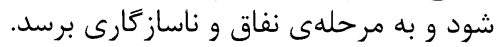

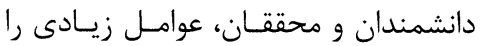

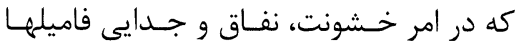

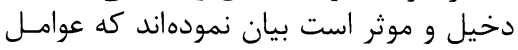

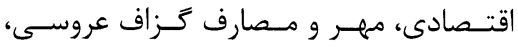

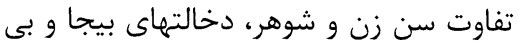

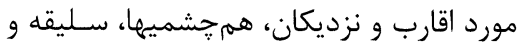

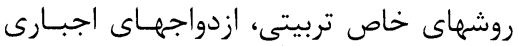

مىبندند، رفاه آسايش و شكوفايى آن جامعـهـ را ضمانت مى كنند. زندكى زن زمانت و شوهرى و تأسيس خـانواده،

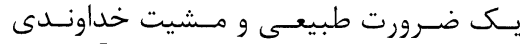

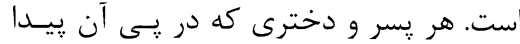

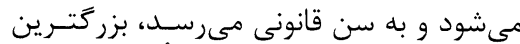

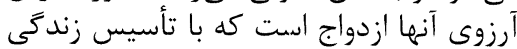

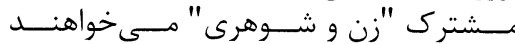

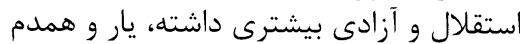

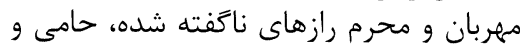

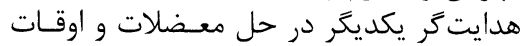

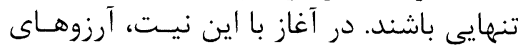

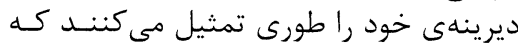

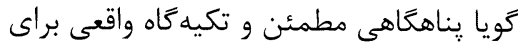

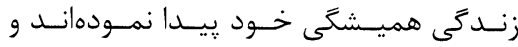

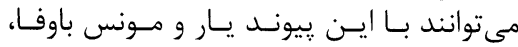

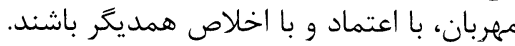

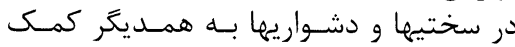

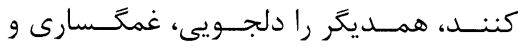

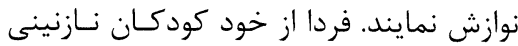

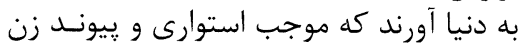

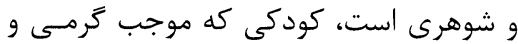

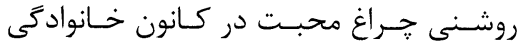

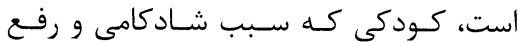

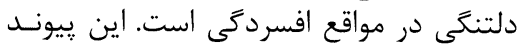

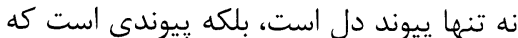

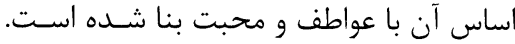

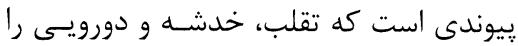

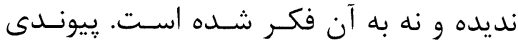

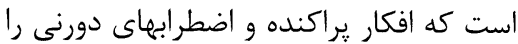

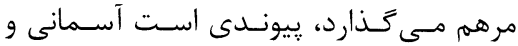

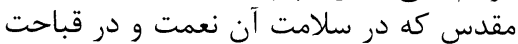

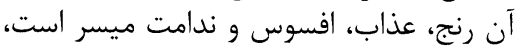

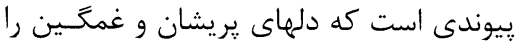

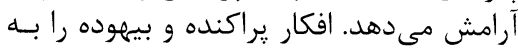

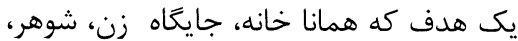

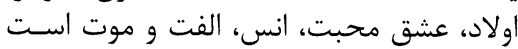

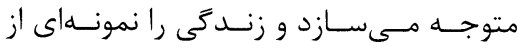

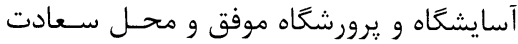

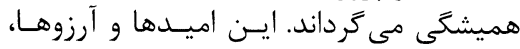

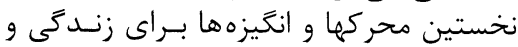

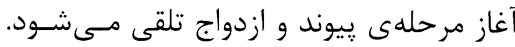

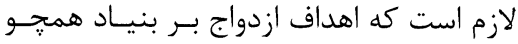

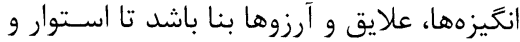

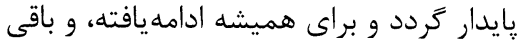

شواهد و رويدادهاى زيادى در جامعـه بـــ

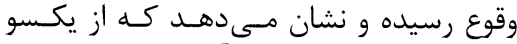

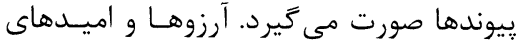

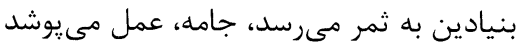

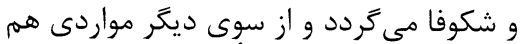

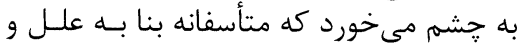

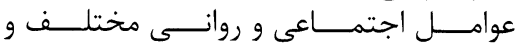




\section{مقالطي}

شده است. زيرا در اين نوع ازدواجها نـه تنهـا

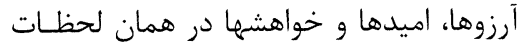

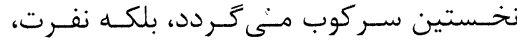

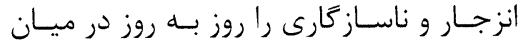

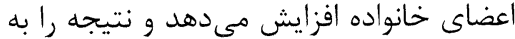

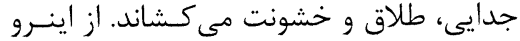

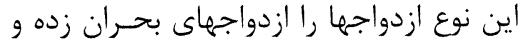

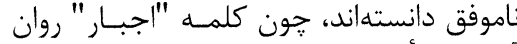

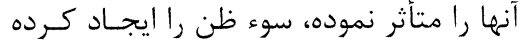

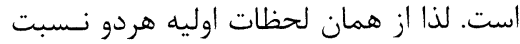

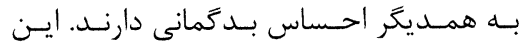

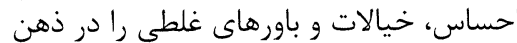

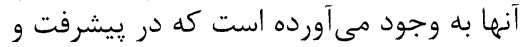

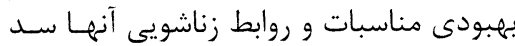

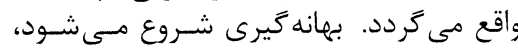

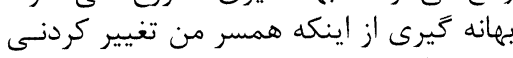

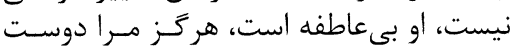

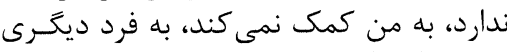

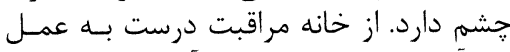

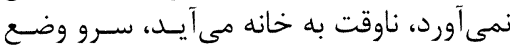

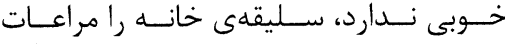

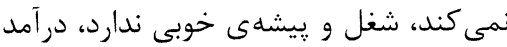

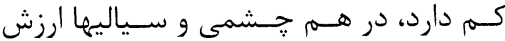

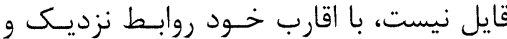

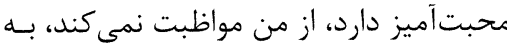

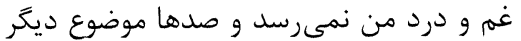

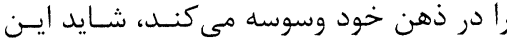

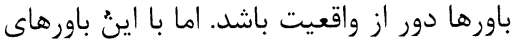

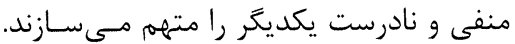

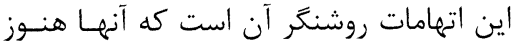

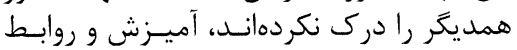

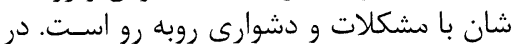

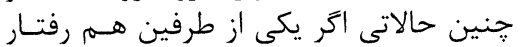

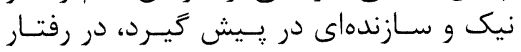

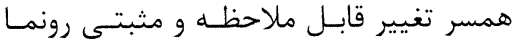

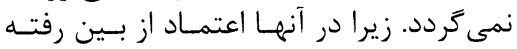

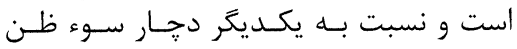

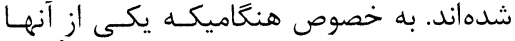

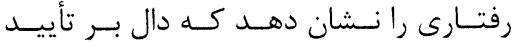
بد بمانيهاى فوق الذكر باشد. در ايسن دئ حـالات

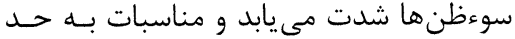

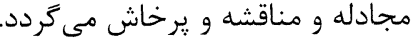

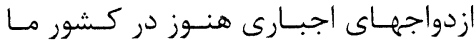

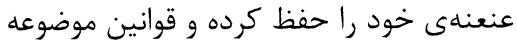

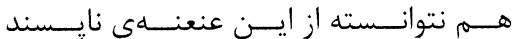
جلوكيرى كند من هم نمى خواهن آهم آنرا آنقدر

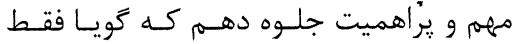

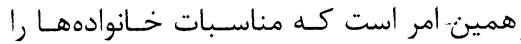

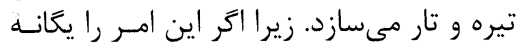

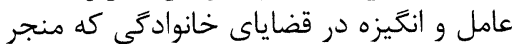

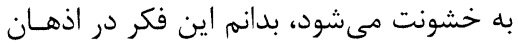

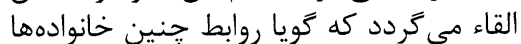

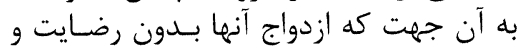

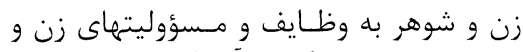

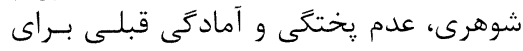

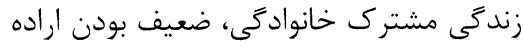

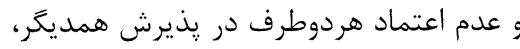

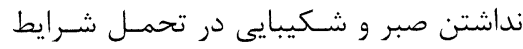

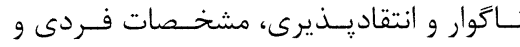

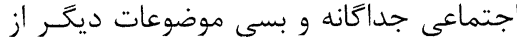

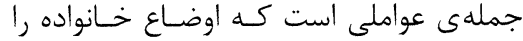

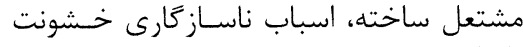

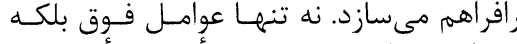

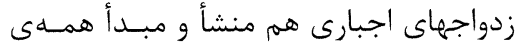

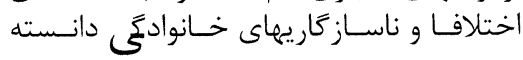
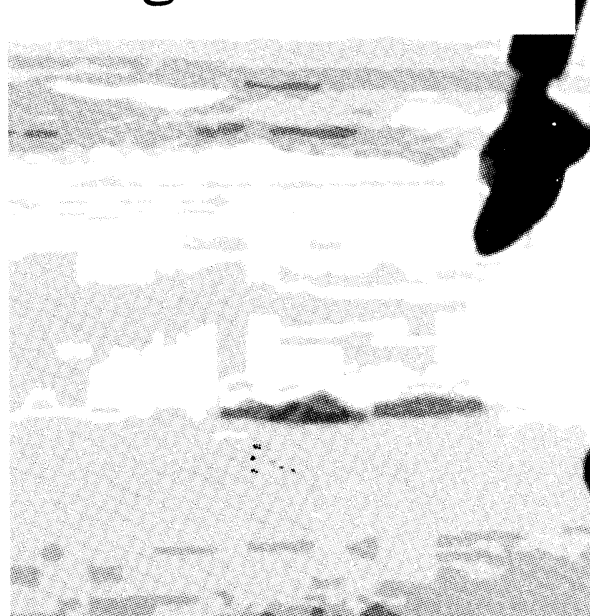
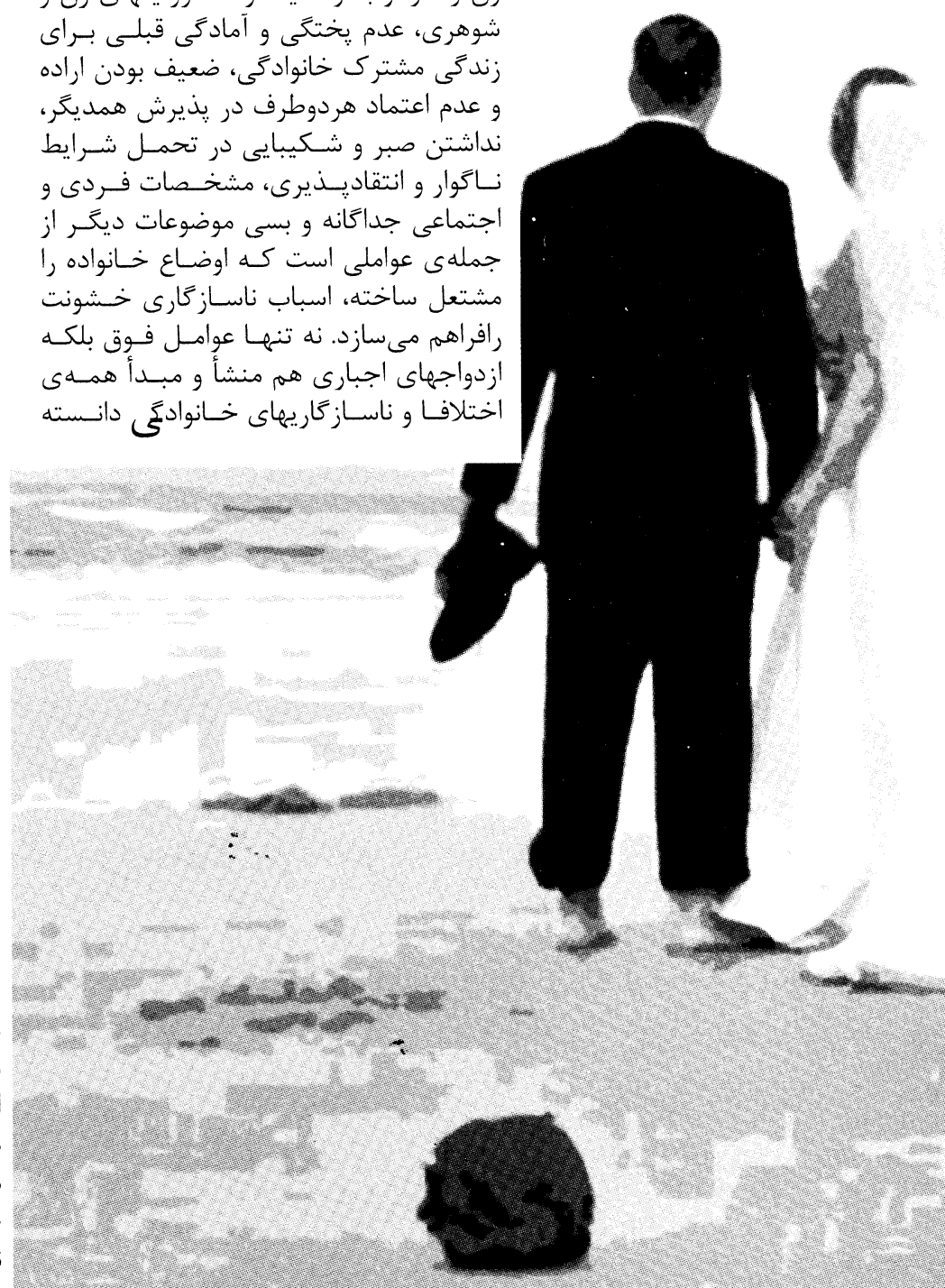

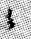

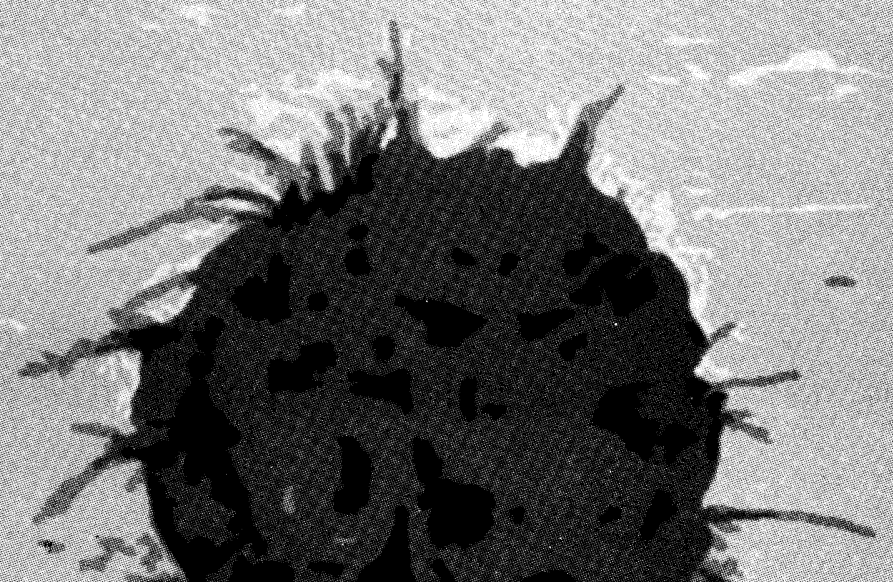




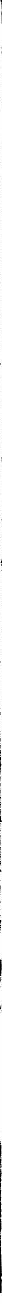

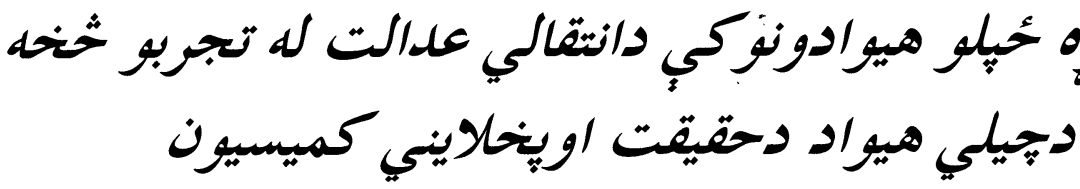

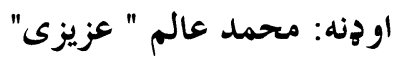

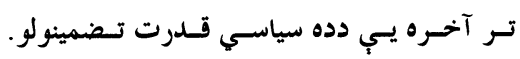

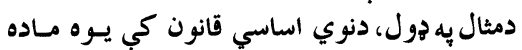

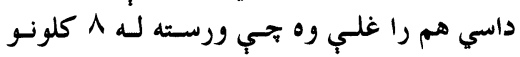

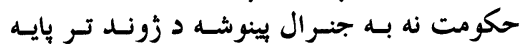

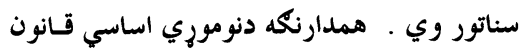

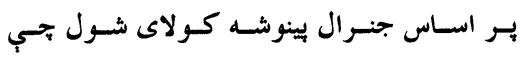

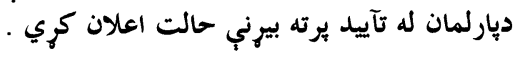

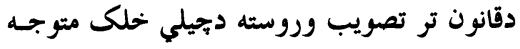

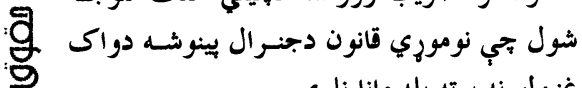

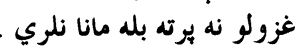

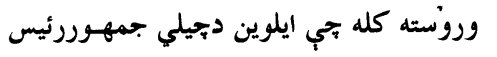

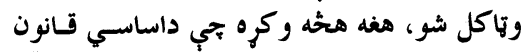

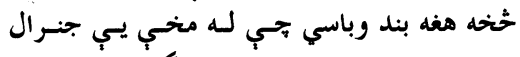

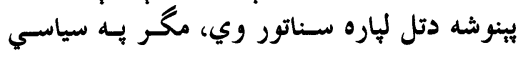

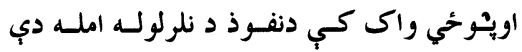

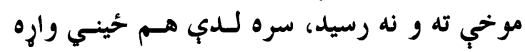

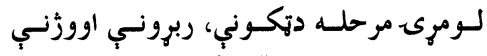

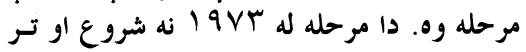

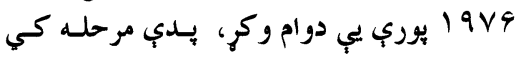

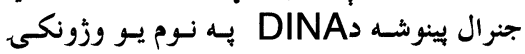

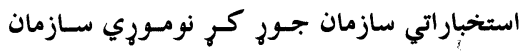

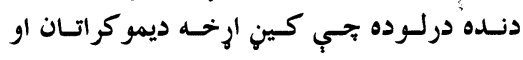

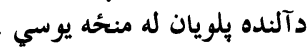

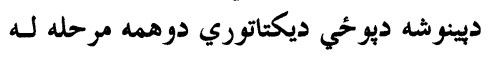

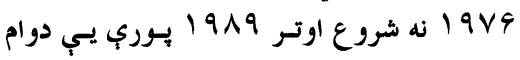

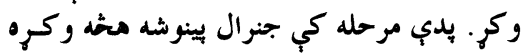

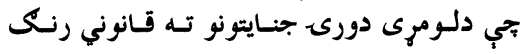

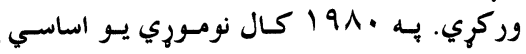

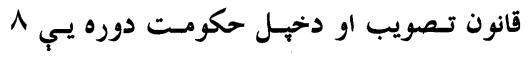

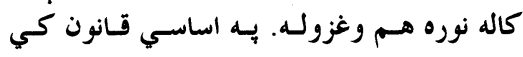

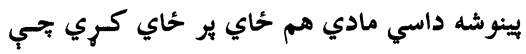
نوموري ته يب قضايي مصونيت وركاوه او دزوند ئدي

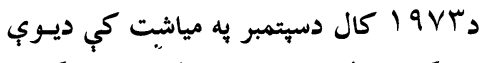

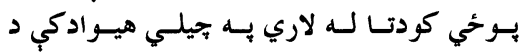

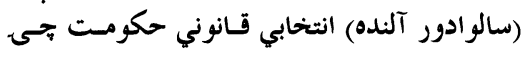

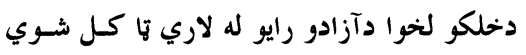
وو رانسكور شو.

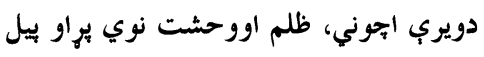

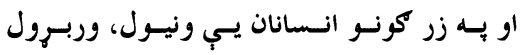

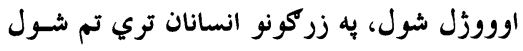

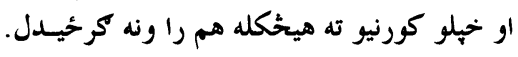

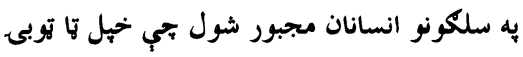

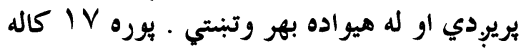

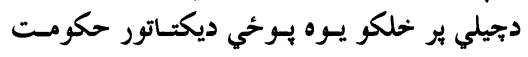

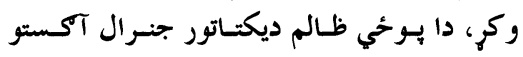

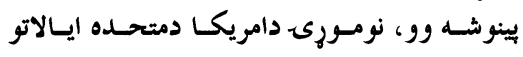
لخوا حمايسه كيـده. دينوشسه نظـامي ديكتـاتوري

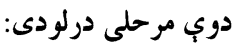


اصلاحات يه قانون كى منحُ ته راغلل

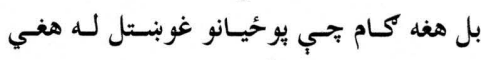
لاري واكى له لاسه ورنكري دملي امنيت دشورا

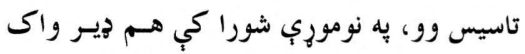

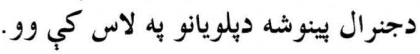

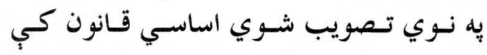

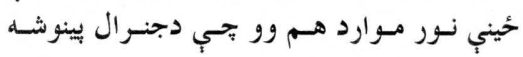

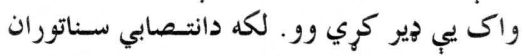

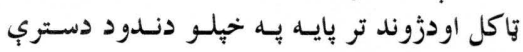

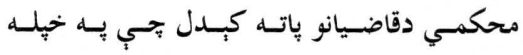

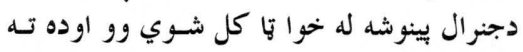

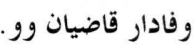
سره له دى تولو هخو تجي يوخيـانو اوجنسرال

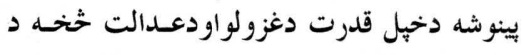

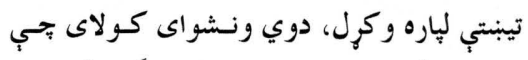

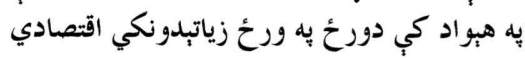
وعدي ير اساس ده دخهيل واك دتسليمدو نه خو وبلل شو. كميسيون له يتو امنيتي مـداركو خخسه يرتسه، نورهر دول دولتي مداركو آرشيفونو اواسنادو تـه

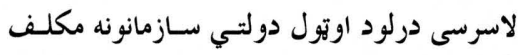

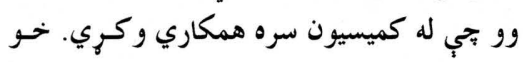
كميسيون نه شواى كولاى تجي يه به جنايـاتو مستهم

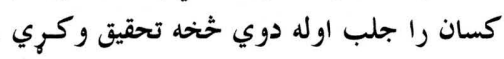

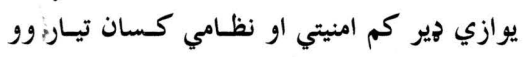

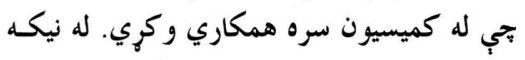

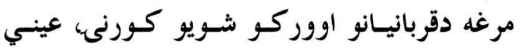
شاهدان او حُيني نادولتي موسسات له كميسيون

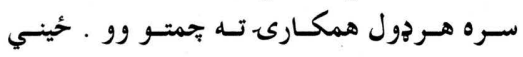

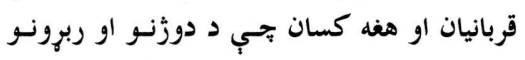

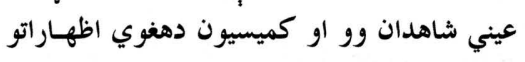

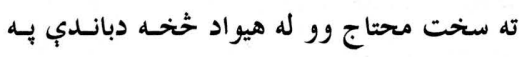

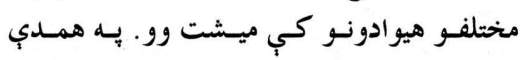

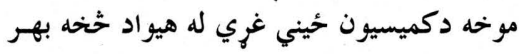

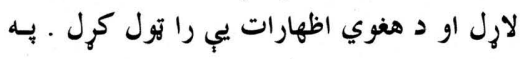
تولو بهرنيو هيوادونو كي دجيلي سفارتونو ته امر إو دوري

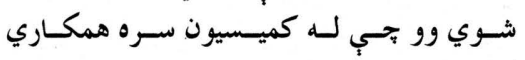
وكري. يسه بــاب كـي د نـه سـتري كيسدونكي كـار

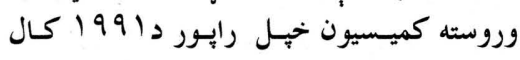

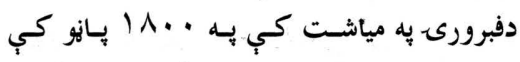

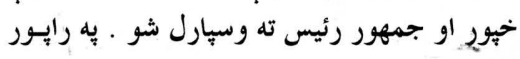

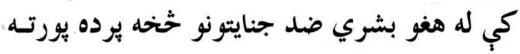

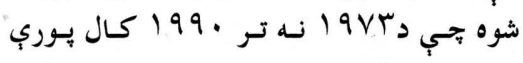
سـرته رسـيدلي وو او هغسه سـازمانونه او دولتسي

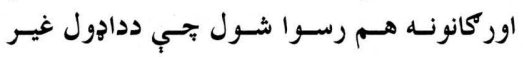

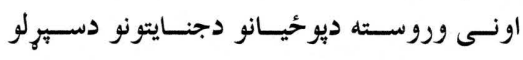

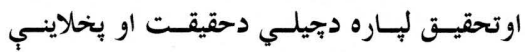

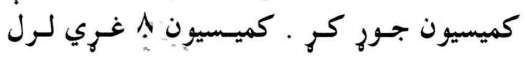
اوتول دجمهوررئيس لخوا وتاكـل شـول. لـه غرو خخه خحلور كسان ديينوشه دمخالف ايستلاف

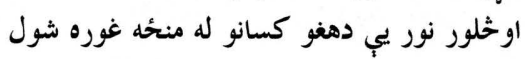

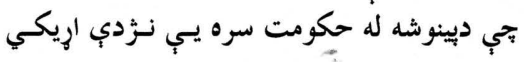

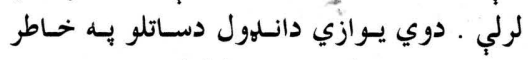

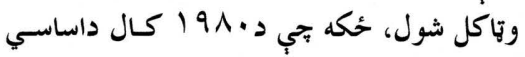

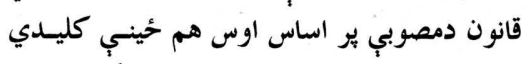

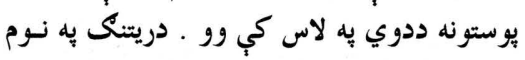

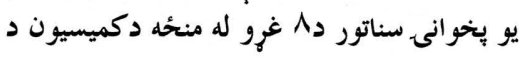

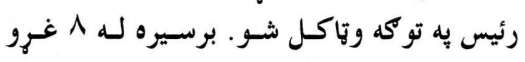

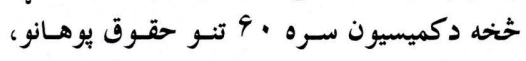

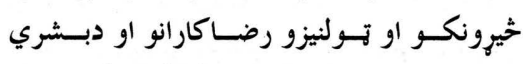

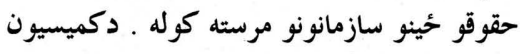

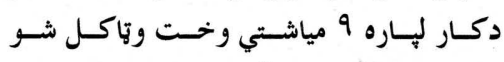

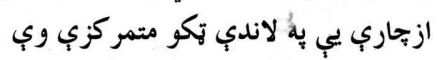

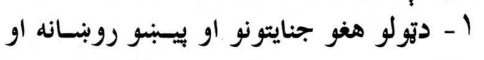

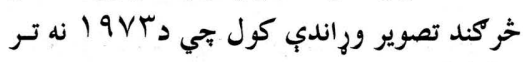

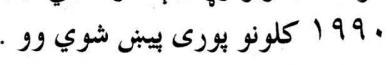

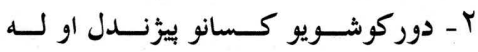
برخليك خخه يب يرده يورته كول

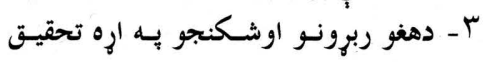

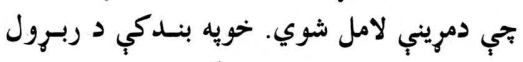

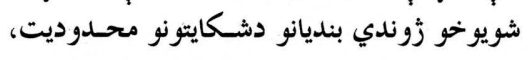

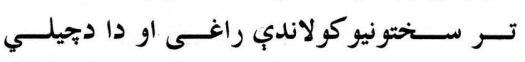
دحقيقت اويخلاينسي دكميسسيون يـو منفـي كـار

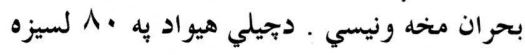

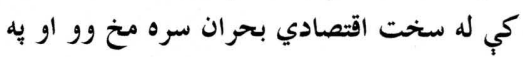

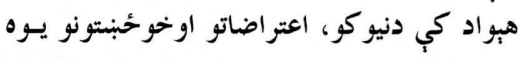

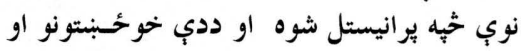

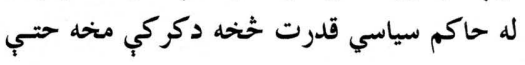
دبيرني حالت اعلانولو هم ونشواى نيسولاى. يـاسه

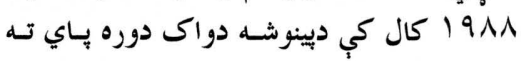

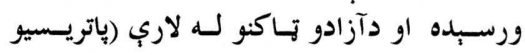

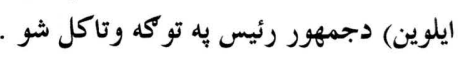

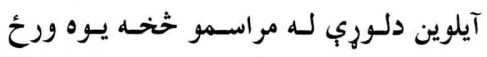

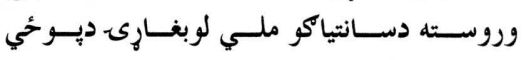

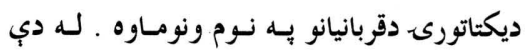

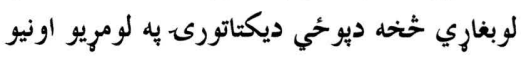
كي ديوحي زندان كار اخيستل كيـده او دوزنس

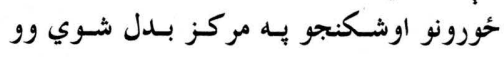

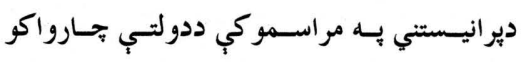

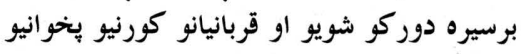

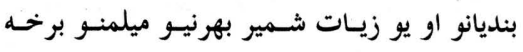

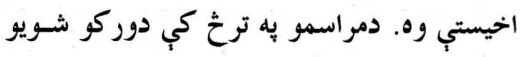

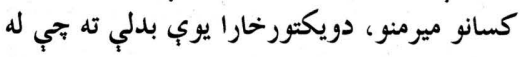

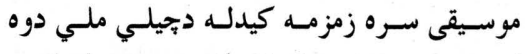

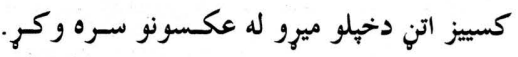

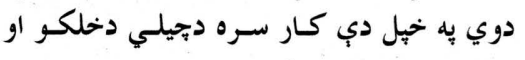

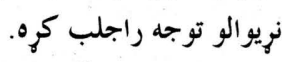

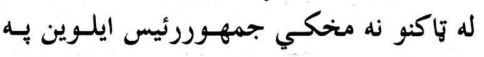

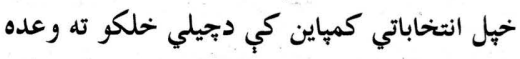

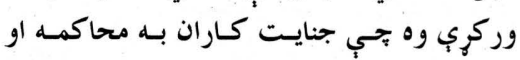
بشري حقوق به رعايت او يلسي كـوي. دهمـدي 


\section{مقاكt)}

شول او له بلي خهوا قربانيسانو او دجيلـي ديـرى دئ

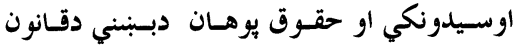

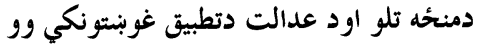

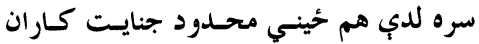

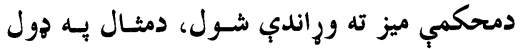

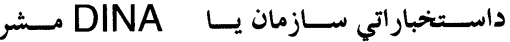

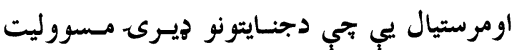

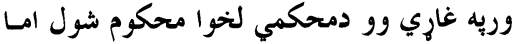
دوي به خهله محكمي ته حاضر نه شول

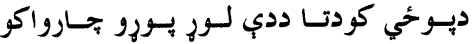

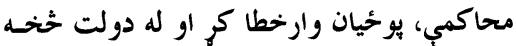

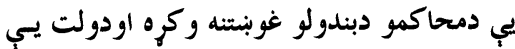
ير كودتا تهديد كر. داستخباراتي سازمان دمشر بنساغلي كونتراس

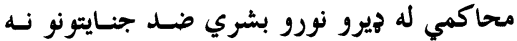

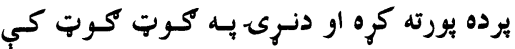

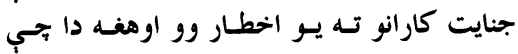

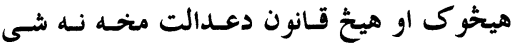

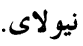
دكونتراس دمحاكمي نه وروسته به جيلي كي

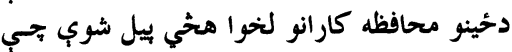

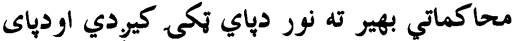

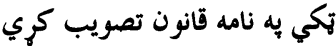

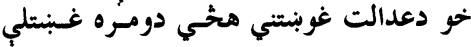

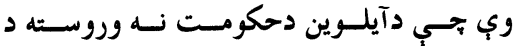
جمهوررئيس فراي دحكومت به دورئ دوران كي هـم

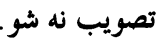

\section{دآكستو يينوشه محاكمه}

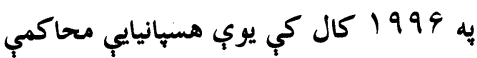

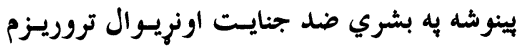

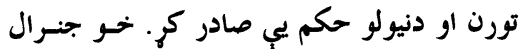

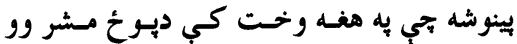

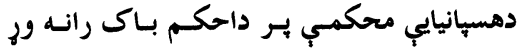

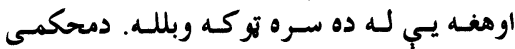

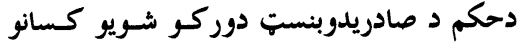

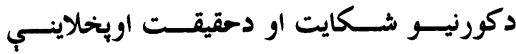

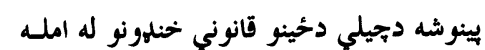
تجي مخنكي ذكر شول، نشواى محاكمه كيدائي،

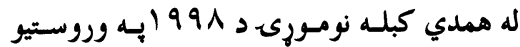

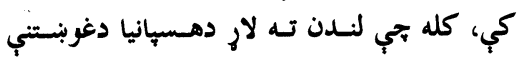

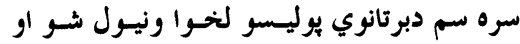

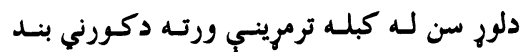

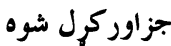

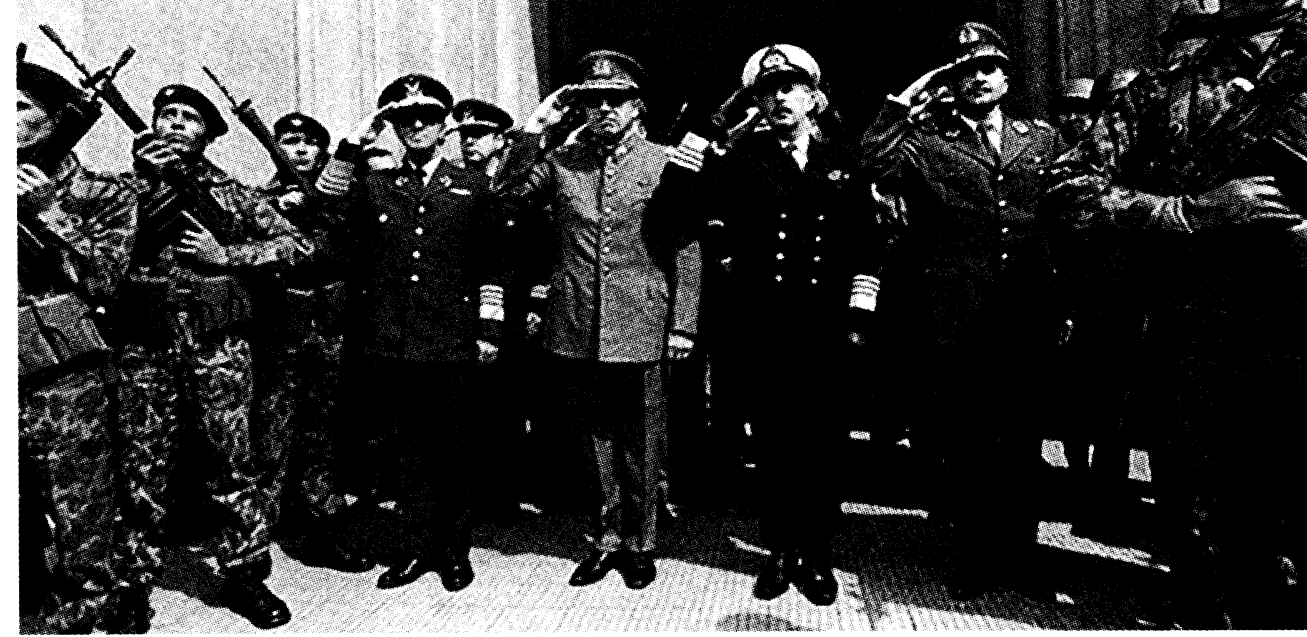

جنايتونو لياره مشخص حسواب نسه درلسود او تر

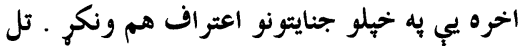

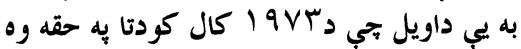

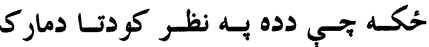

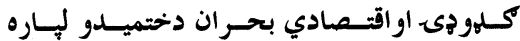
وشوه. همداراز ديوخي ديكتاتوري ددفاع وزيـر

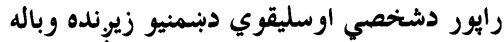

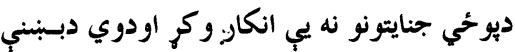

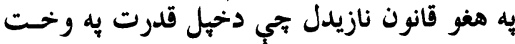

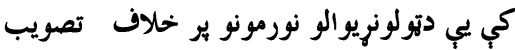

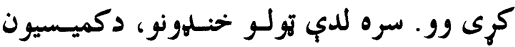

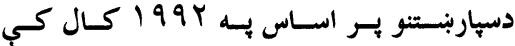

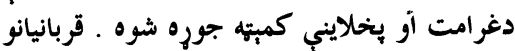

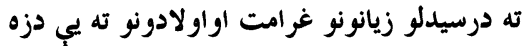

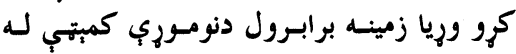
مسوليتونو خخخه وو زئه دجيلـي دحقيقـت او بخلاينسي دكميسسيون

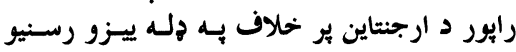

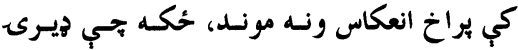

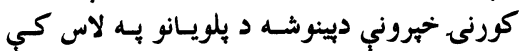
وي، دوي به دي بلمه بجي تير به هير اوري إتلونيكي

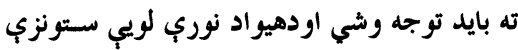
بايد حل شي د انتقالي عدالت دتطبيق به وراندي إندي

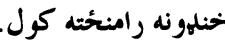

$$
\text { سزاوي: }
$$

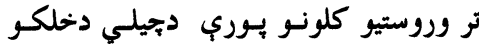

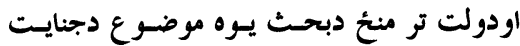

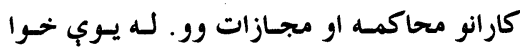

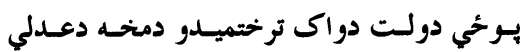

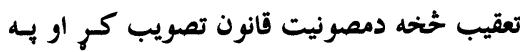

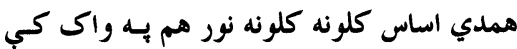

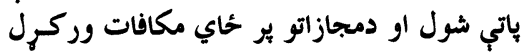

انساني او بشري ضد جنسايتونو دتنظيم مسسوول وو. ددانول دولتي اور كانونو له جملي حثخه تر

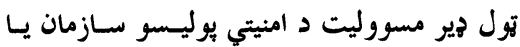

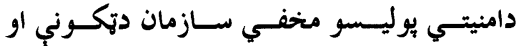

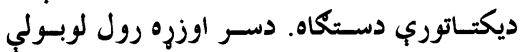

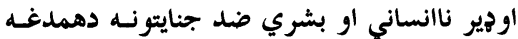
سازمان له لوري سرته رسيدلي دي مئي

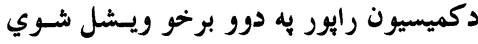

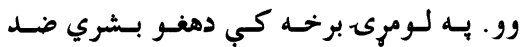

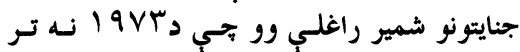

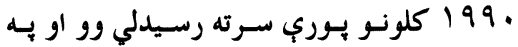

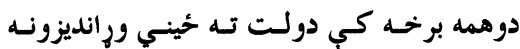

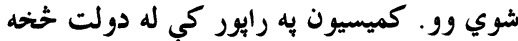

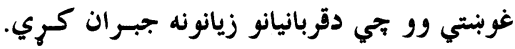

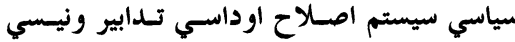

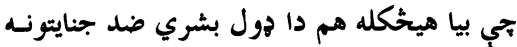

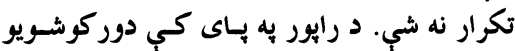
كسانو نومونه هم راغلي ورو تهري

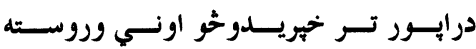

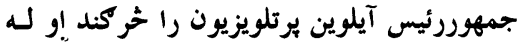

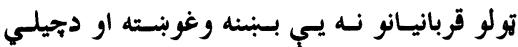
خلك يب بنسني اويخلايني ته وهخول

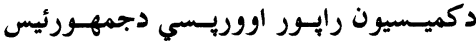

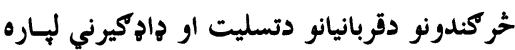

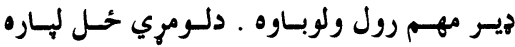

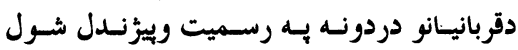

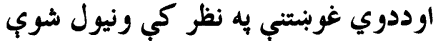

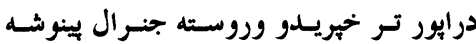

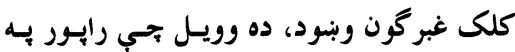

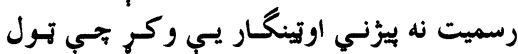

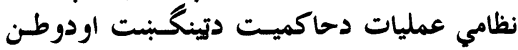
دآرامي لياره وو، خو ده بـه رايسور كي دراغلو

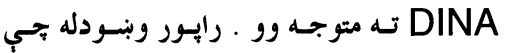

(a) نولو لهارهكرامت او عدالت 
اول از همه برايت آرزومندم كه عاشق شوى

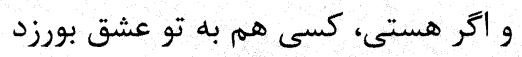

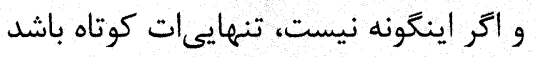
و يس از تنهايىات، نفرت از كسى نيابى.

آرزومندم كه اينگُونه پِيش نيايد، اما اتر يِيش آمد

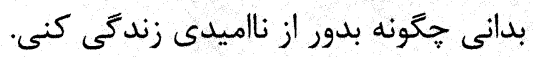
برايت همجنان آرزو دارنه دوستانى داشته باشى از جمله دوستان بد و نايايدار برخى نادوست، و برخى دوستدار

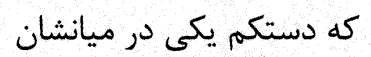
بى ترديد مورد اعتمادت باشد. و جون زند بكى بدين گونه است

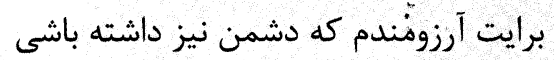

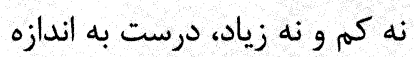

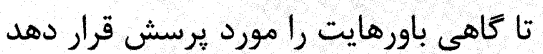

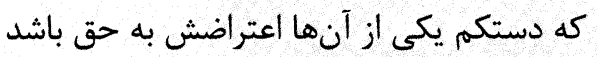

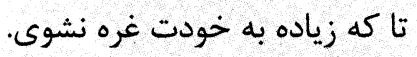

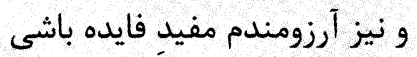
نه خيلى غيرضرورى نيز تا در لحظات سخت وقتى ديگر جيزى باقى نمانده است همين مفيد بودن كافى باشد تا تو را سرِ پِا نتحهدارد.

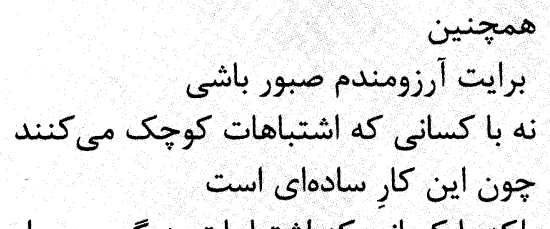

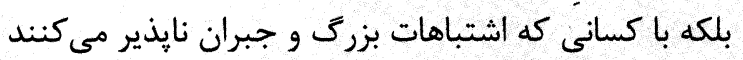

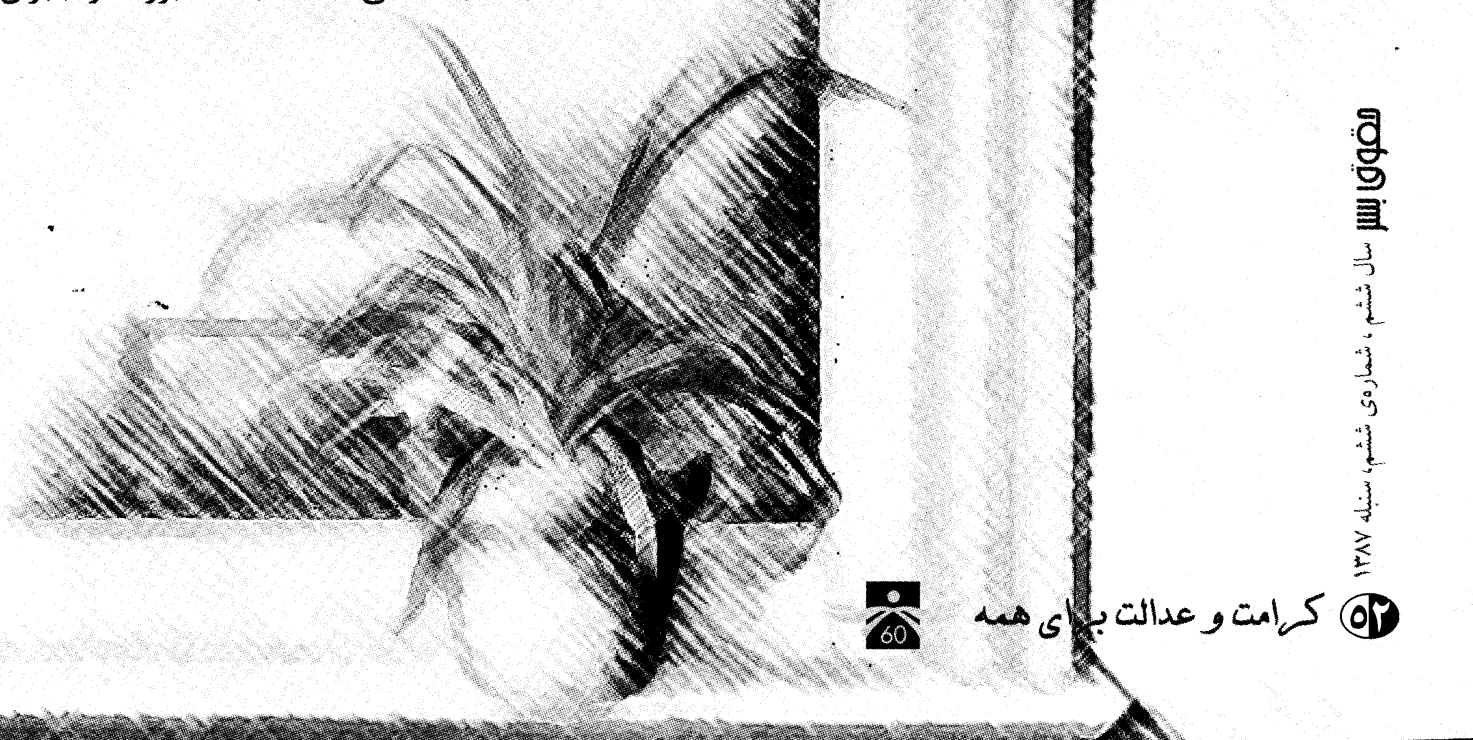


و با كاربرد درست صبورىات براى ديخران نمونه شوى.

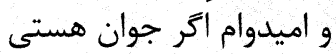
خيلى به تعجيل، رسيده نشوى اميدوان

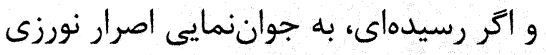
و اكر ييرى، تسليم ناميدى نشوى ريدى

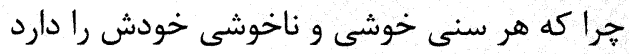
و لازم است بحذاريم در ما جريان يابند.

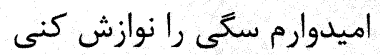

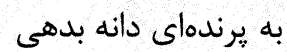
و به آواز يك سنهره گوش كنى دانه بدهي

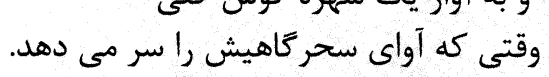

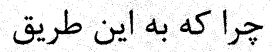
احساس زيبايى خواهى يافت، به رايگان.

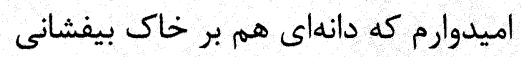
هرجند خُرد بوده باشد واند و با روييدنش همراه شوى

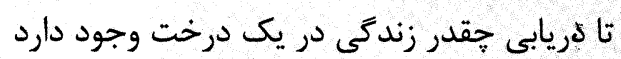

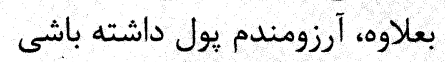

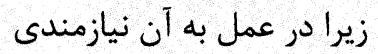
و براى اينكه سالى يك بار

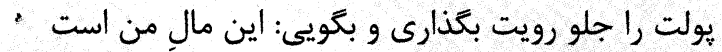
فقط براى اينكه روشن كنى كدامتان ارباب ديكرى استا و در پايان، اكر مرد باشى، آرزومندم زن خوبى داشته باشى و آر زنى، شوهر خوبى داشته باشى

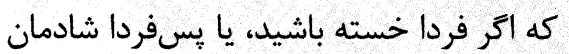
باز هم از عشق حرف برانيد تا از نوبياغازيد.

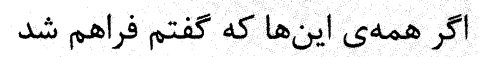
ديكر جيزى ندارم برايت آرزو كنم

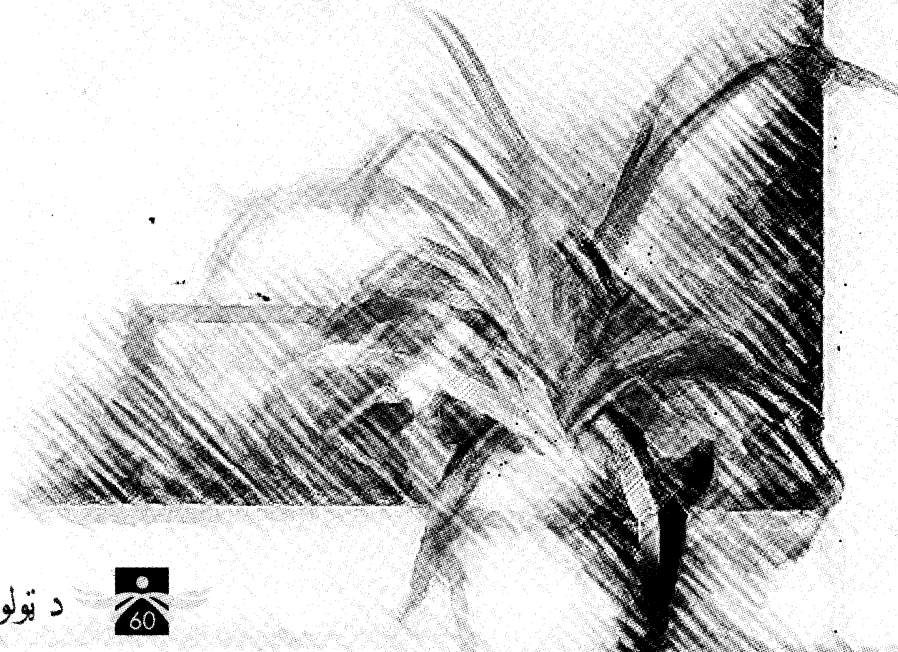




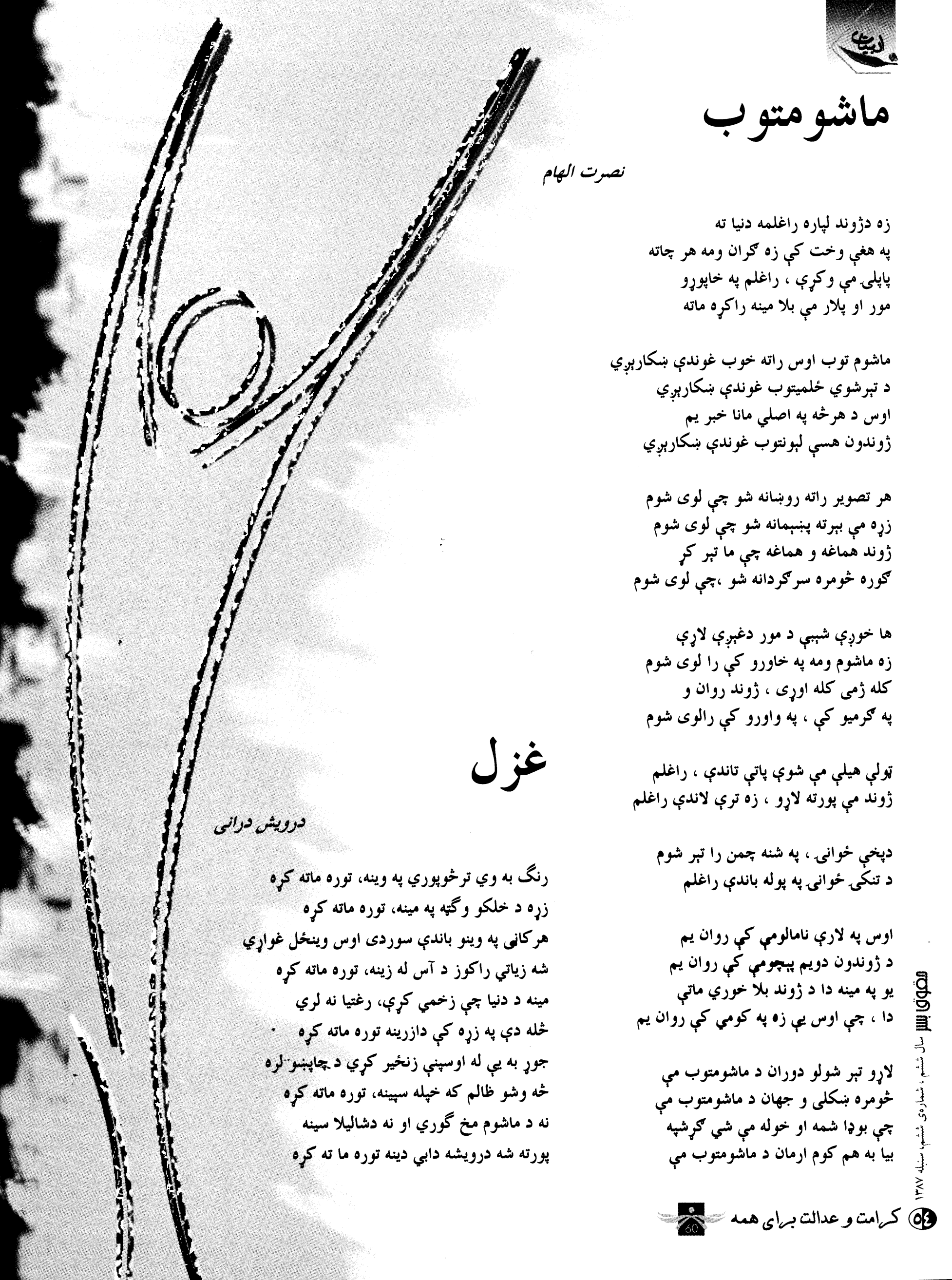









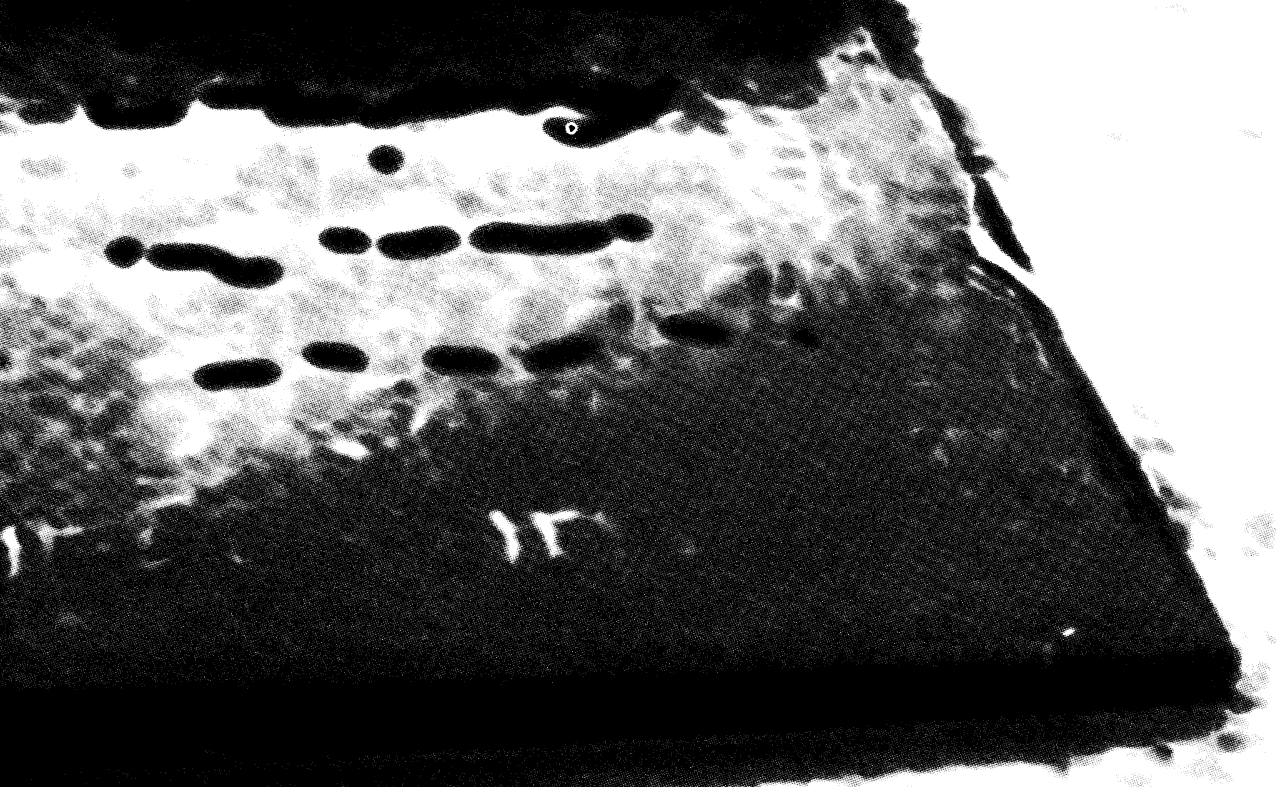

ازدواج كرده بودند. حاجى بعد از ازدواج رفته بود نجف. كربلايى و ميرزا مانده بودئ بودند و نامه ازده

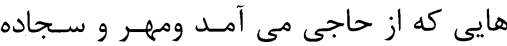

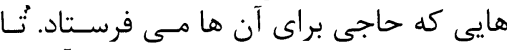

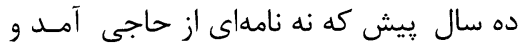

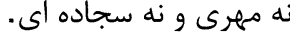

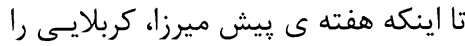

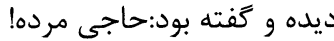

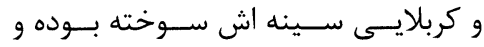

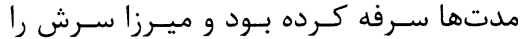

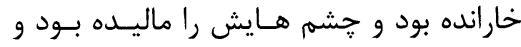

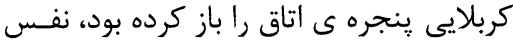

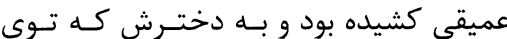

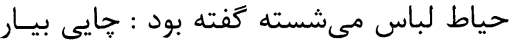

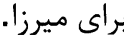

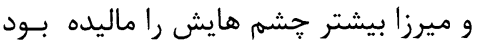

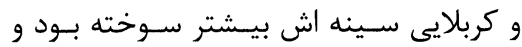
خس خسش بيشتر شده بود.

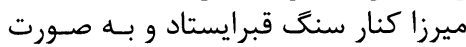

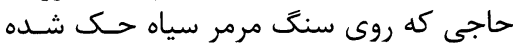

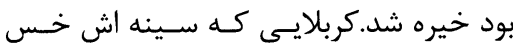

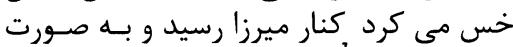
حاجى روى سنَّ سياه خيره شدر. ميرزا كفت:خودشه؟ سين خين

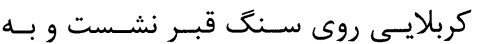

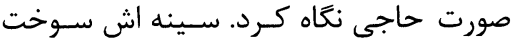

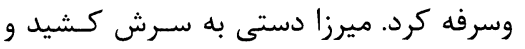
جشم هـايش سـوخت و كنــار كربلايسى روى نـ سنگ قبر نشست...
وقوطى ناسش را از داخل جيب كتش بيرون

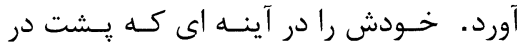

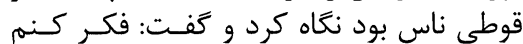
امروز يا فردا حتما برف مي كي آيد.

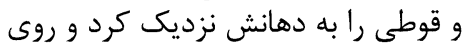

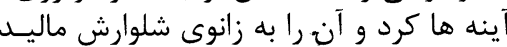

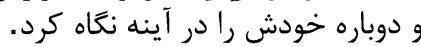

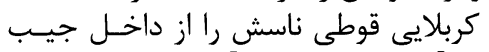

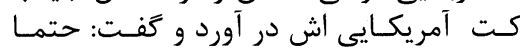

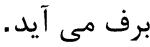

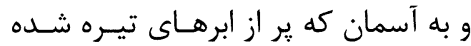

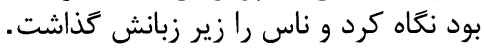

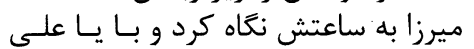

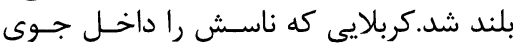

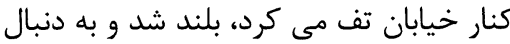
ميرزا كشيده شد. ميرزا سرفه اى كرد و كفــت : يـادش بـ بـهـ

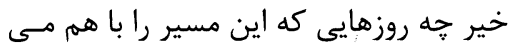
رفتيم سر كار، هي يادش به به خير!

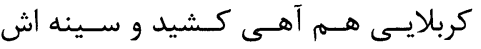
سوخت و شروع به سرفه كردن كرد.

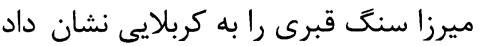

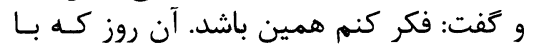

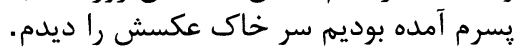

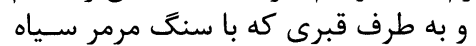
تزيين شده بود رفت. كربلايى هم بـ بـه دنبـال

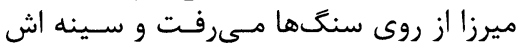

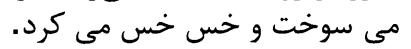

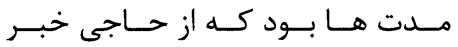

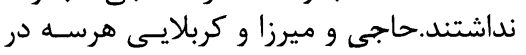

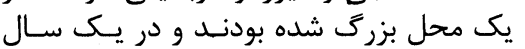

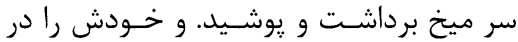

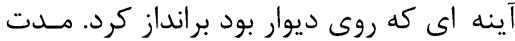

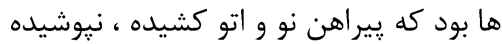

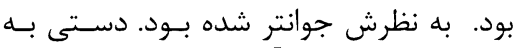

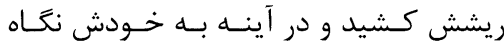

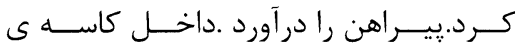

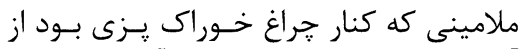

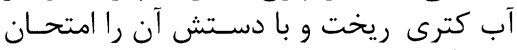

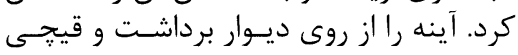

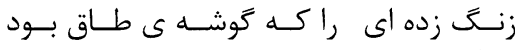
برداشت.

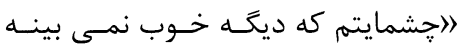
كربلايى " باحثمانه كسـه خــودش در آينــه نتخـاه كـرد و آهـى كشيد. كربلايسى در اتـاق را قفـلـ مسىكـرد كـهـ دخترش او را ديد. - سلام صبح بخير!

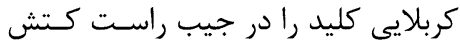

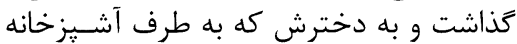

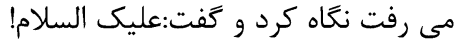
و سرفه ى خشكى كرد نكاه كرد كفت

-كجا صبح به اين زودى كربل كردي كردي؟

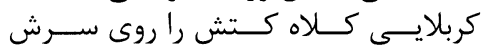

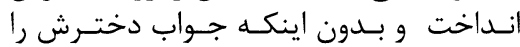
بدهد از در حياط بيرون آيدون آمد.

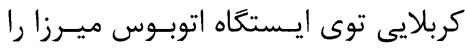

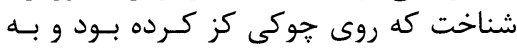

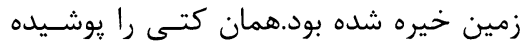

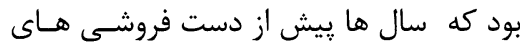

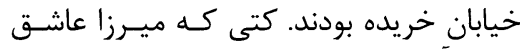

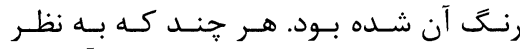

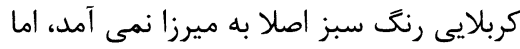

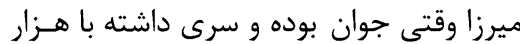
سودا، شكيبه دختر همسايه ى شئ شان به به ميرزا

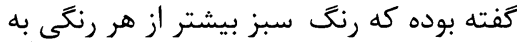

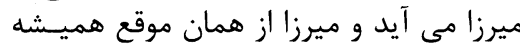

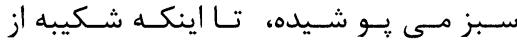

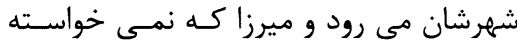

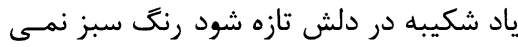

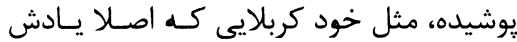

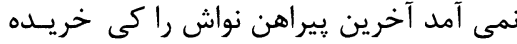

$$
\text { كربلايسى سـرفه اى كـرد و كنـار ميـرزا }
$$

ميرزا سرش را بالا آورد و به كربلايى كـهـ

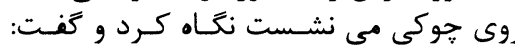

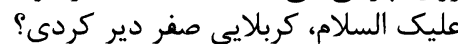

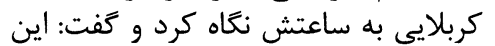

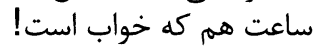

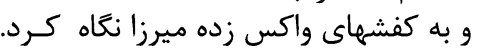

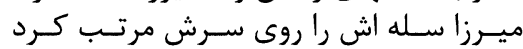




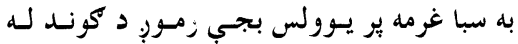

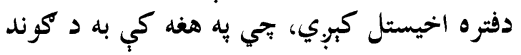

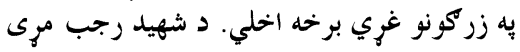

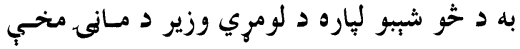

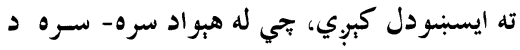

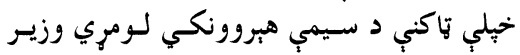

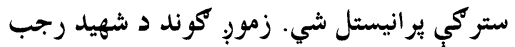

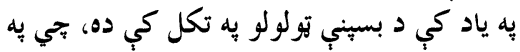

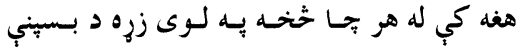

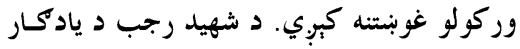

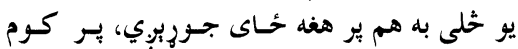

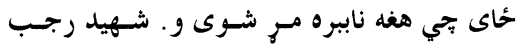

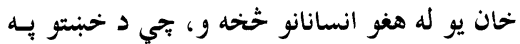

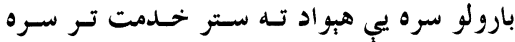

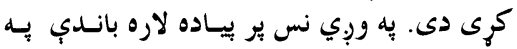

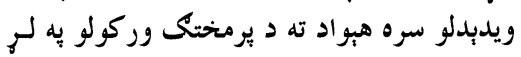

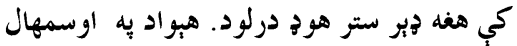

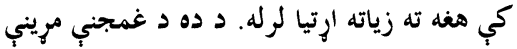

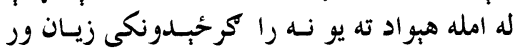
"

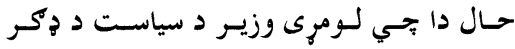

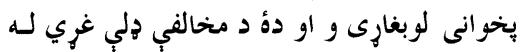

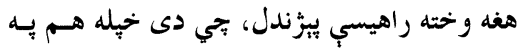

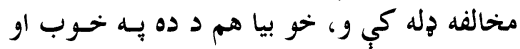

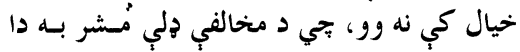

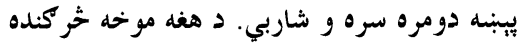

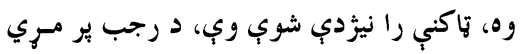

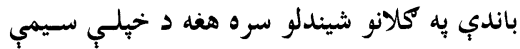

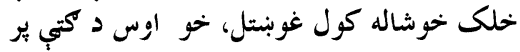

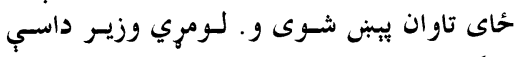

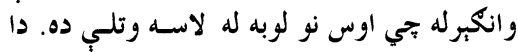

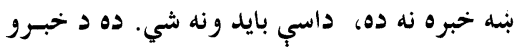

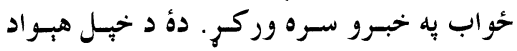

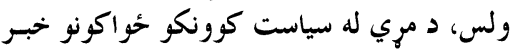

جارو وزير، د جحايبريال ساتني وزير او د اقتصاد

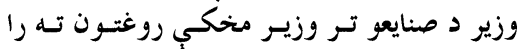

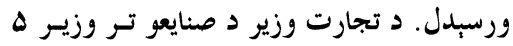

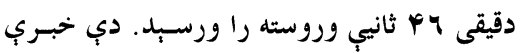

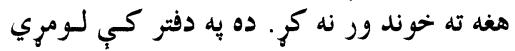

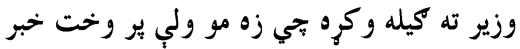

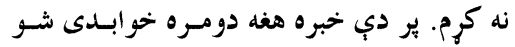

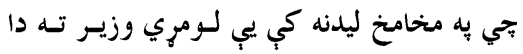
كيله وكره. د يارلمان د مخالفي ذُلي مشر ته دا خبسر بـهـ

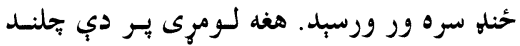

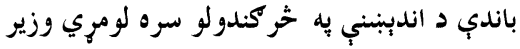

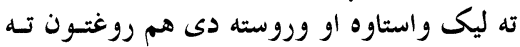

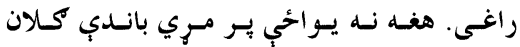

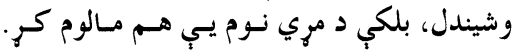

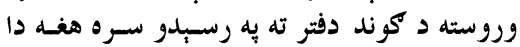

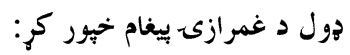

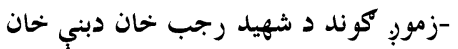

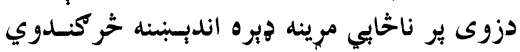

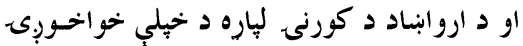

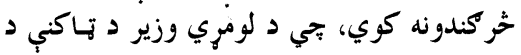

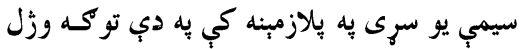

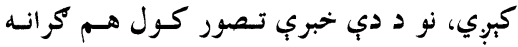

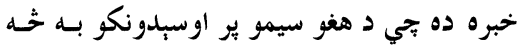

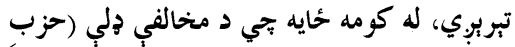

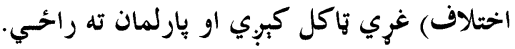

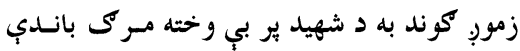

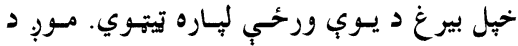

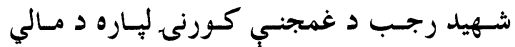

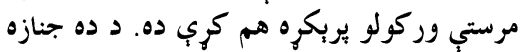

هغه بير بياده لاره ويده و، جي يوه لارى يـر

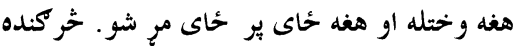

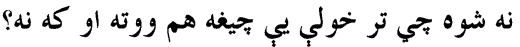

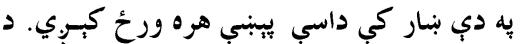

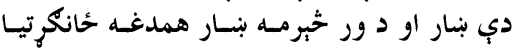

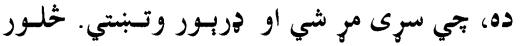

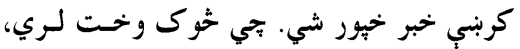

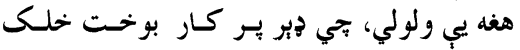

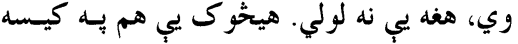

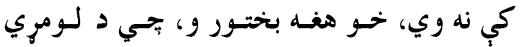

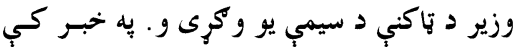

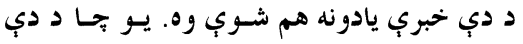

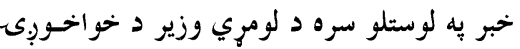

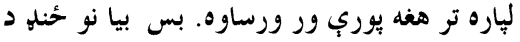

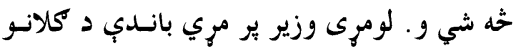

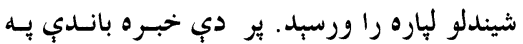

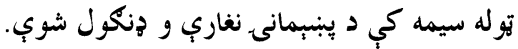

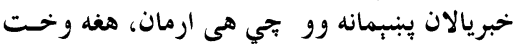

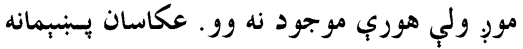

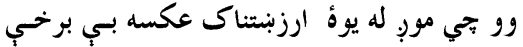

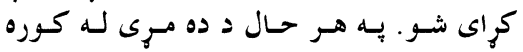

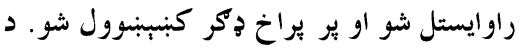

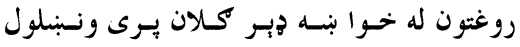

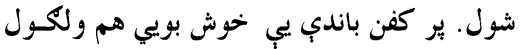

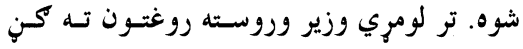

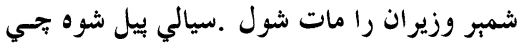
تر لومري وزير وروسـته خــوكى يسر دويسم لمبسر

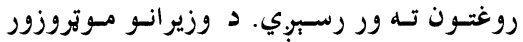

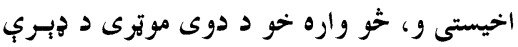

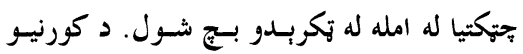

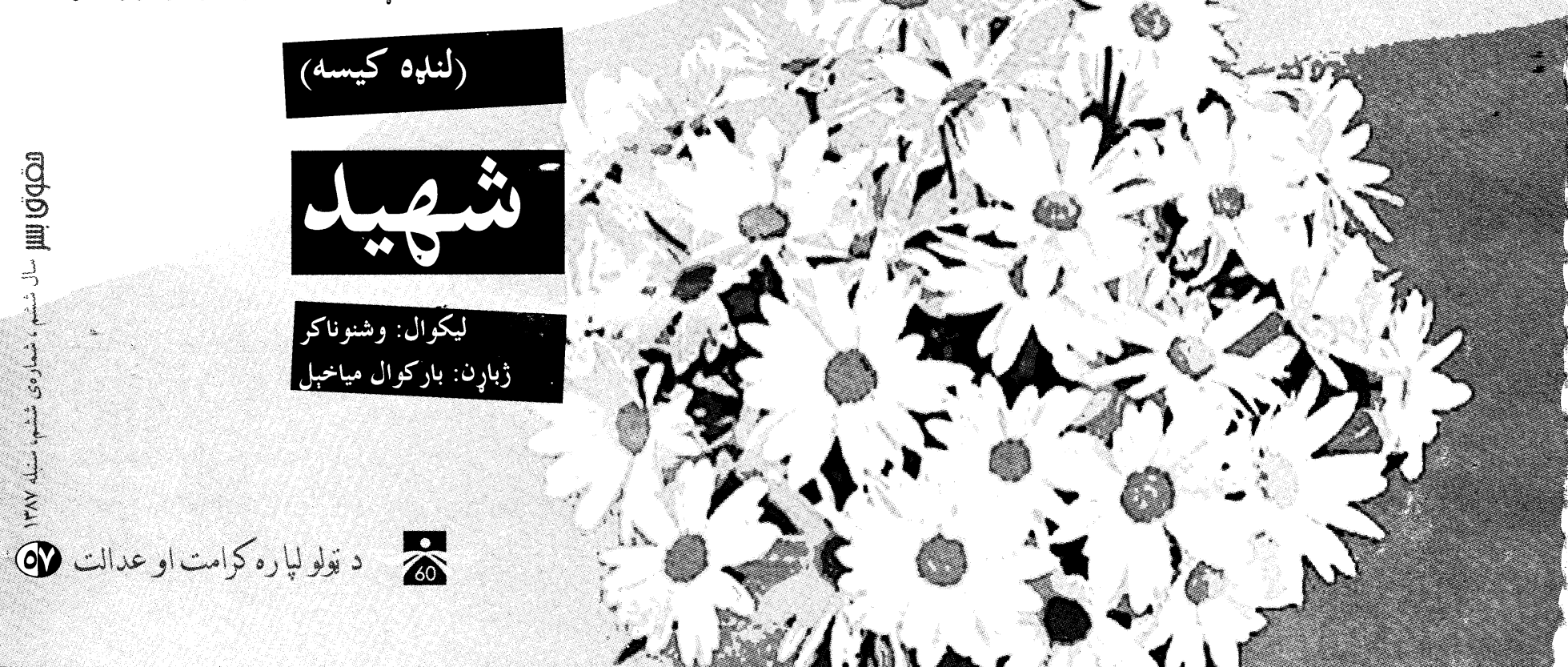


خركندولو سره تي لومرى وزير به دي ته به پيام

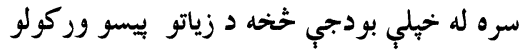

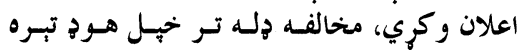

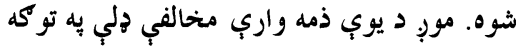

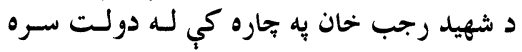

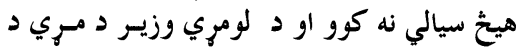

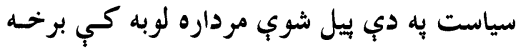

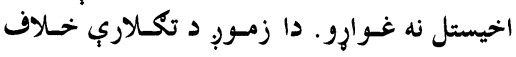

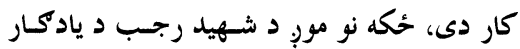

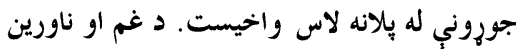

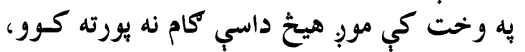

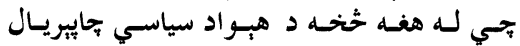

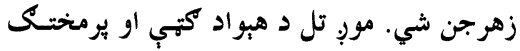

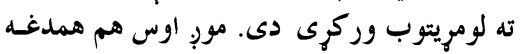

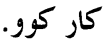
له دي وروسته د لومري وزيـر وينـا ورانـدي

"دا بنسه خبــره ده جـي زمسوبِ تـر فـشار

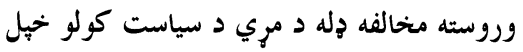
ناوره كار ته حير شوي ده او بيرته يي لاس تسري

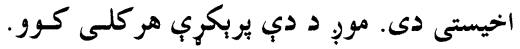

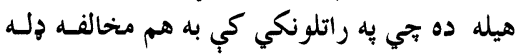

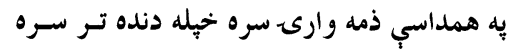

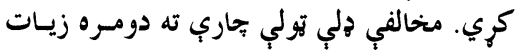

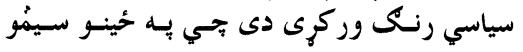

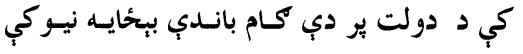

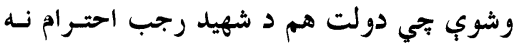

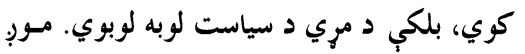

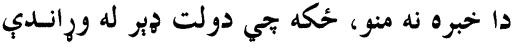

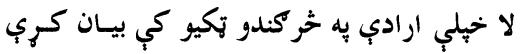

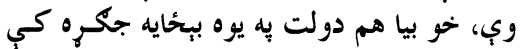

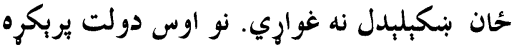

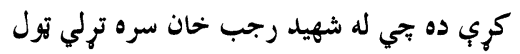
يروكر امونه او اعلانونه دي بيرته واخيستل شئ دي.

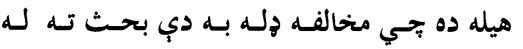

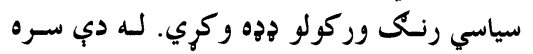

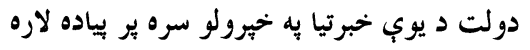

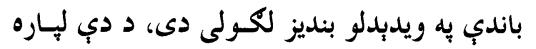

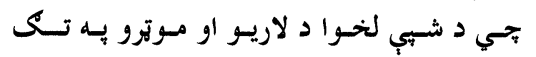

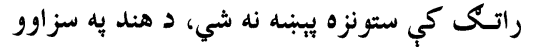

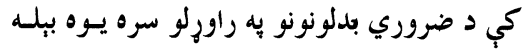

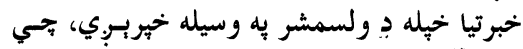

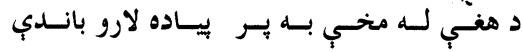

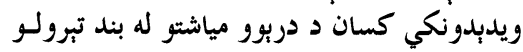

سره سره، لس زره روبيى جرمانه هم وركوي.
به هم د روزكار وركولو لياره غور وشي، ير دي

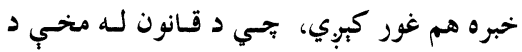

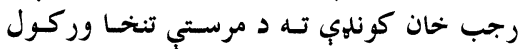

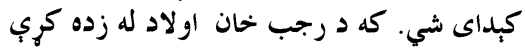
سره مينه ولري، نو دو هغوى لياره به د و وريـا زده

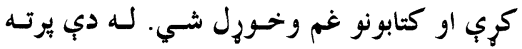

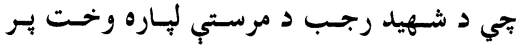

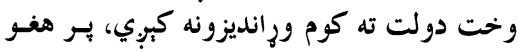
به غور كي.ري.

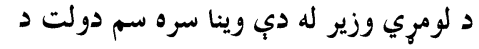

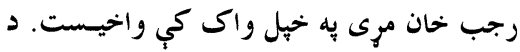

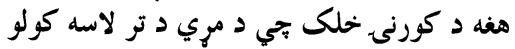

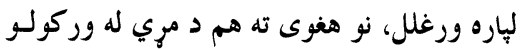

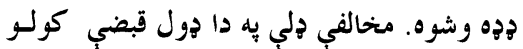

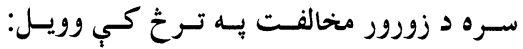

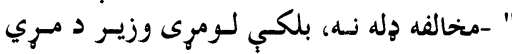

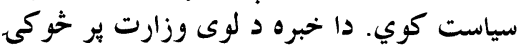

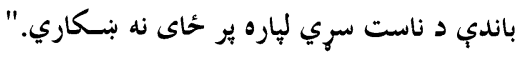

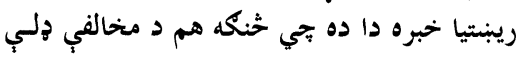
د شهيد رجسب د غمجنسي او بسي وِّتسه مرينسي

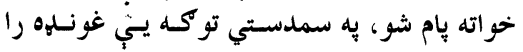

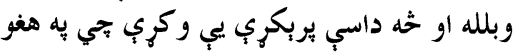

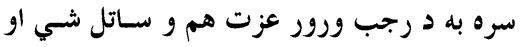

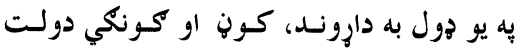

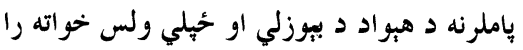

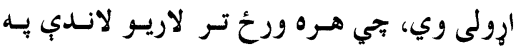

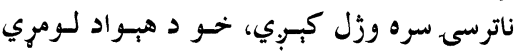

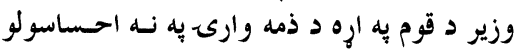

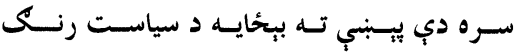

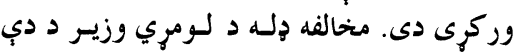
زيانمني ناز كمز اجى او غير ذمهـ واره بيلاريتسوب مخحالفت كوي.

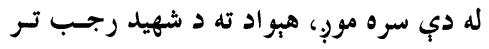

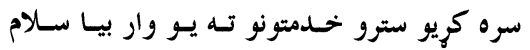

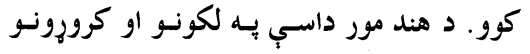

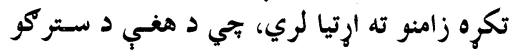

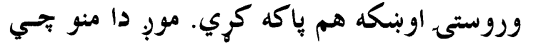

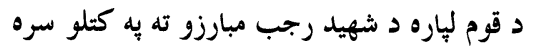

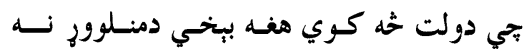

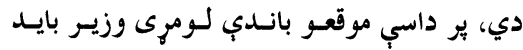

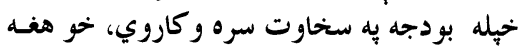

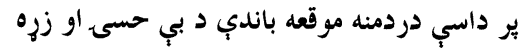

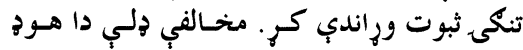

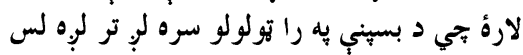

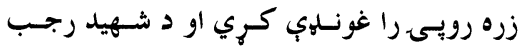

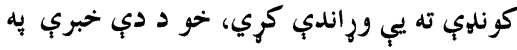

كر. ده به خهلو خبرو كي وويل:

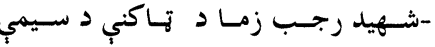
اوسبدونكى و، ما له ده سره فطري ترون درلسود

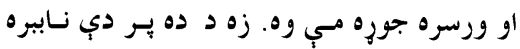

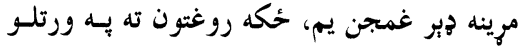

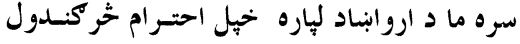

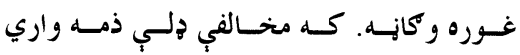

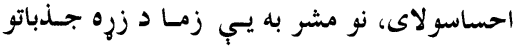

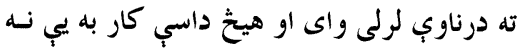

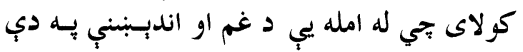

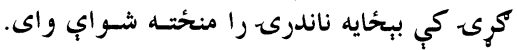

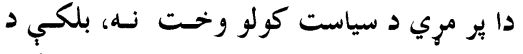

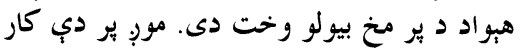

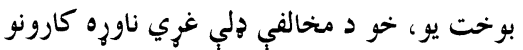

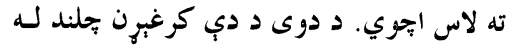

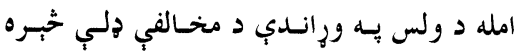

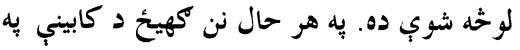

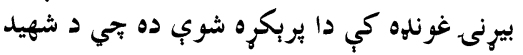

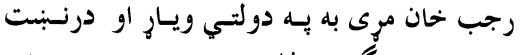

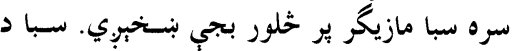

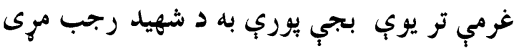

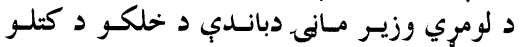

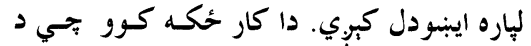

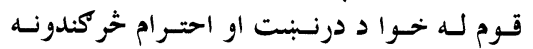
وشي، جي هغوى يب د داسي خلكو لِيساره لـري،

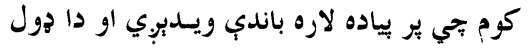

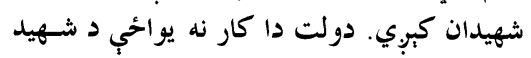

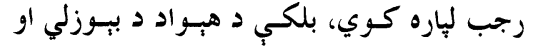

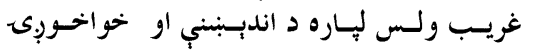

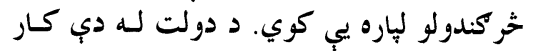

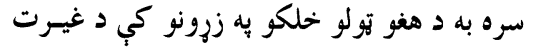

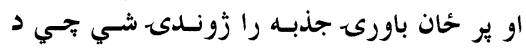

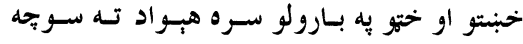

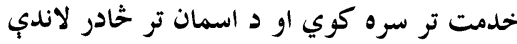

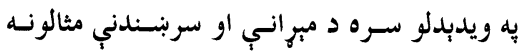
ورجاندي كوي. د تول قوم لـه خسوا يسه دي توكسه تـر مـركى

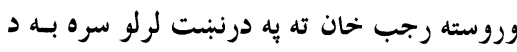
مري د سياست كوونكو له لاسه يوه بلـه موقعسه ووخي. دا دولت د ولس به ببخسي زيسات ملاته

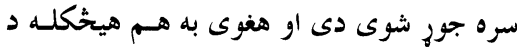
داسي سياست كولو اجازه ور نه كـري. كـابيني

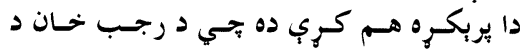

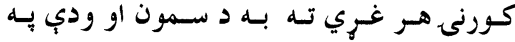

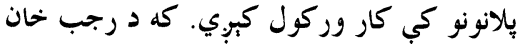
يه كورنى كي يو لوستى كس هم وي، نو هغه ته 


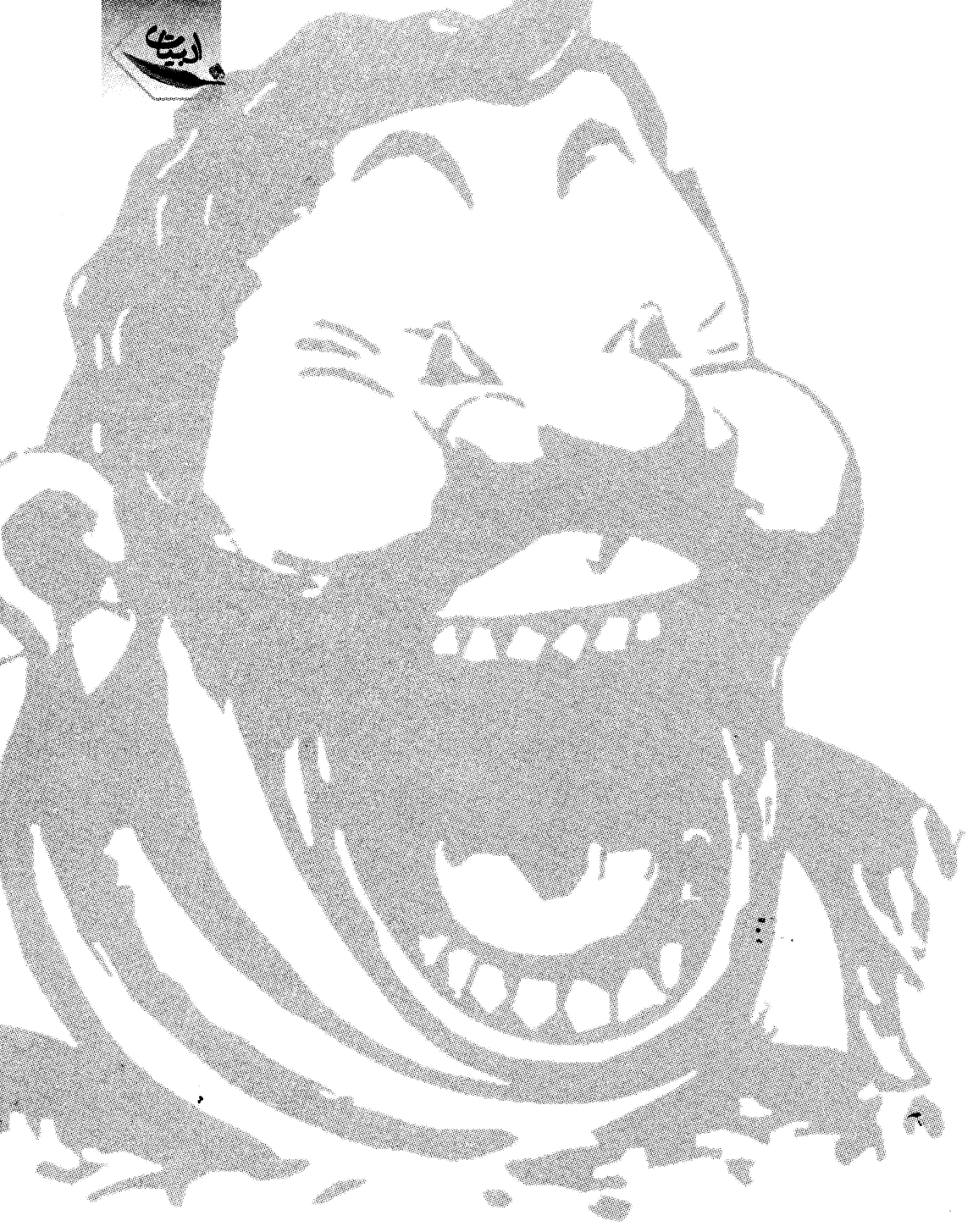

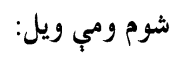

- دخداي بامان كه دموزيم كار سـمشـو مـان

،غ هل ... زما خبره يري كره:

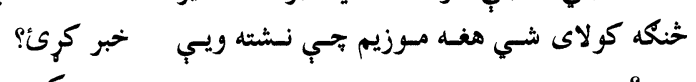

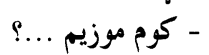

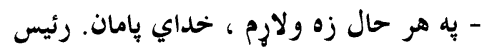

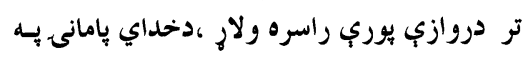

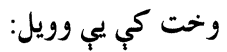

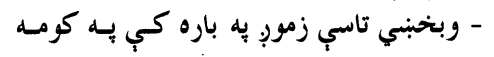

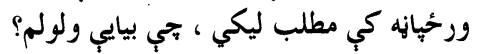

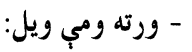

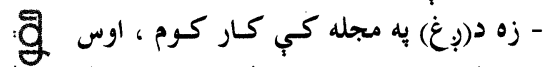

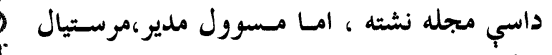

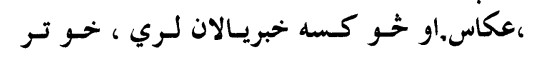

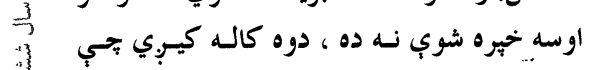

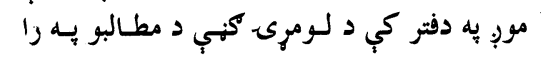

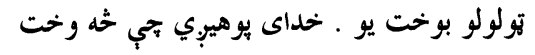

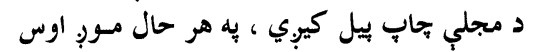

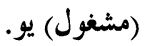

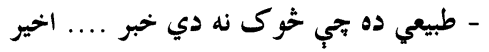

ويني؟

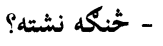

- نشته،

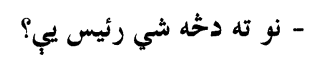

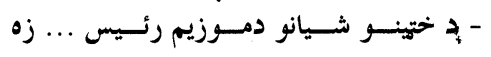

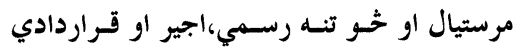

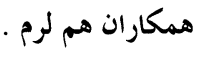

- عجيب نو موزيم هيري دي؟

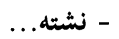

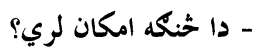

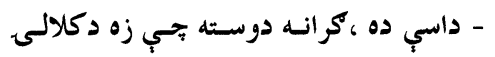

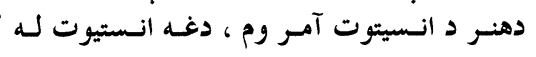

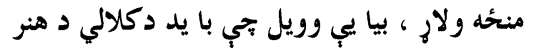

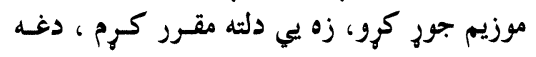

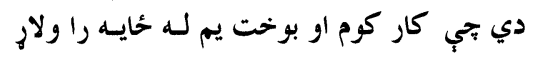

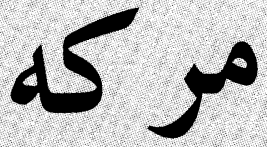

ليكو ال: يوردان يوبوف زباره: علم گل سحر يورد

يـه يـوه ورخيانسه كـي مسي يسوه اووبده مقاله ولوستله خي سر ليك يي دا وو: ( ختهّ دانسان

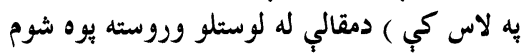

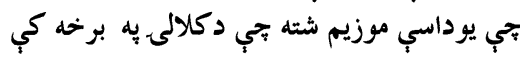

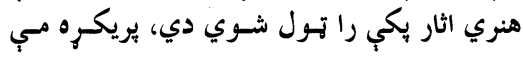

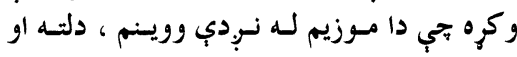

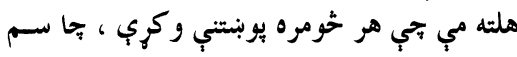

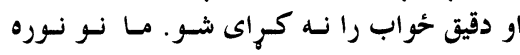

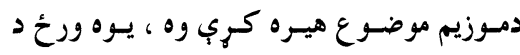

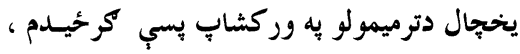
يو خحاي مي يوه لوحسه وليدله (( دختينسو شسيانو

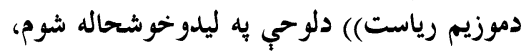

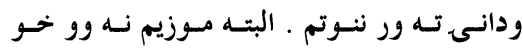

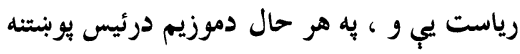

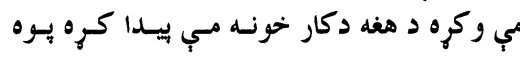

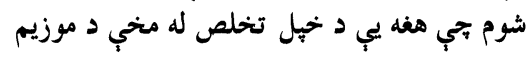

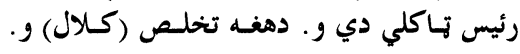

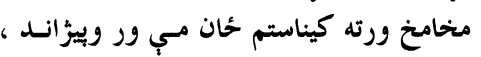

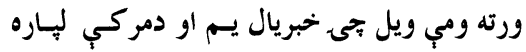

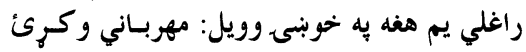

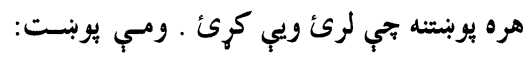

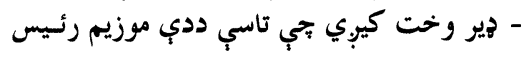
ياست؟

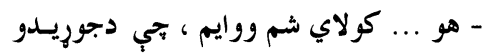
له كاله، يعني خلور كاله دمخهم.

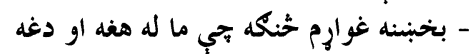

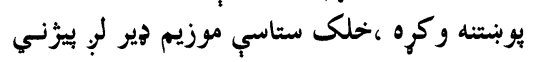

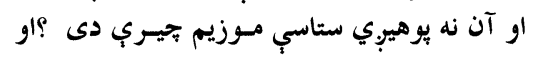




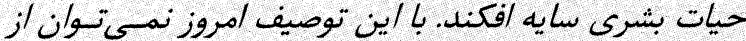

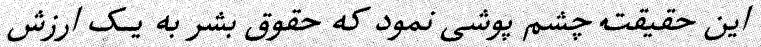

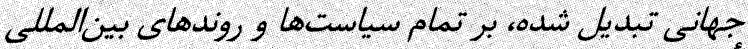
تأثيرات قاطع برجاي مينهيد.

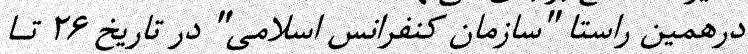

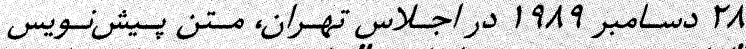

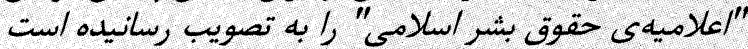

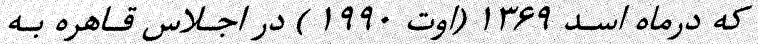

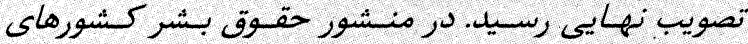

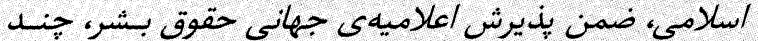

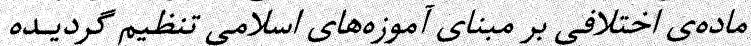

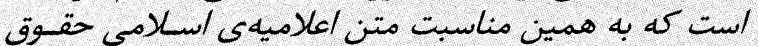
بشر براى خواندكان عزيز به نشر مىرسد:
براى قرن بيسته نامهاى كوناكونى به كار بـرده مسى شـود :

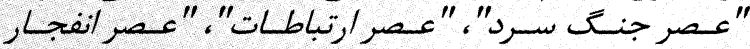

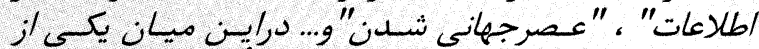

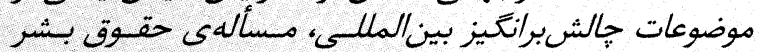

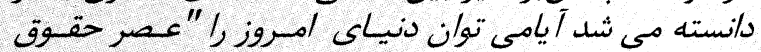

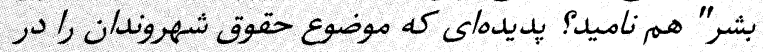

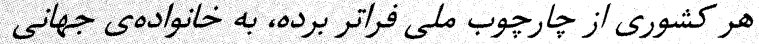

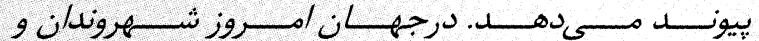

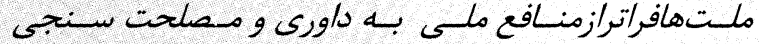

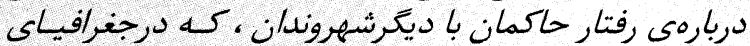

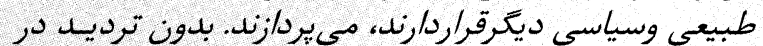

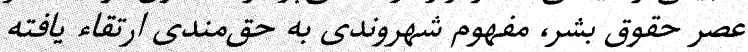
است ومى رود كه به مثابسهى جنبشهى جهانى بركسترونى

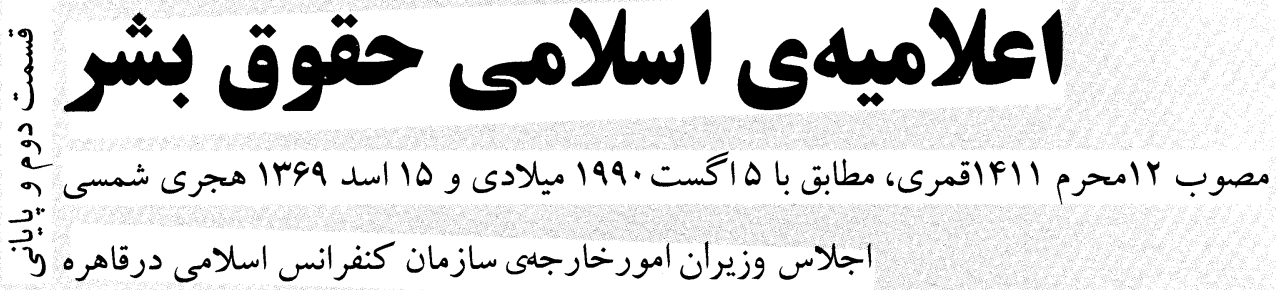

مادهى بيست ويكم: مانمي كروكان كيرى به هرشكلى و به خاطر هرهدفى ، ممنوع

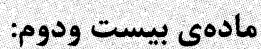
الف : هرانسانى حق دارد كادي كه نظرخود را با به هرشكلى كعه

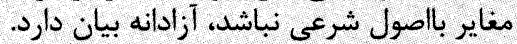

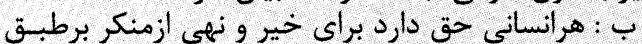

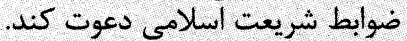

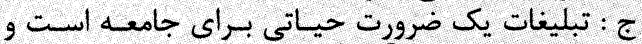

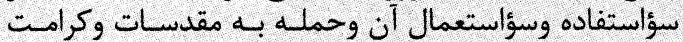

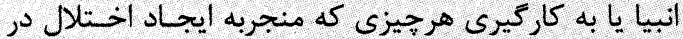

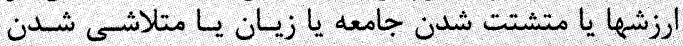

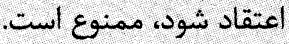

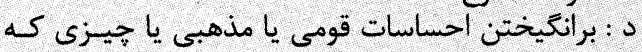

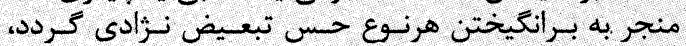
جايزنيست مادهى بيست وسوم: مانيت

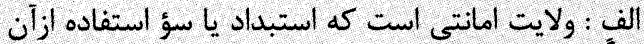

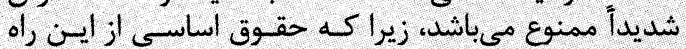
تضمين مي شيود مئر ب : هرانسانى حق دارد دراداره امور عمومى كثور خـود

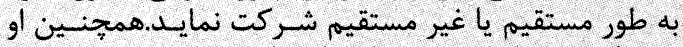
مى تواند بِتهلى عمومى را برطبق احكام شريعت متصدى ني

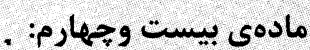

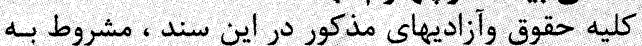

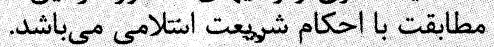

مادهى بيست وينجم: مارئ

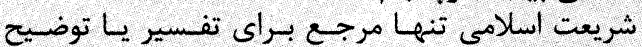
هرماده ازمواد اين اعلاميه مىباشيد. $\therefore$

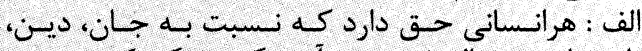

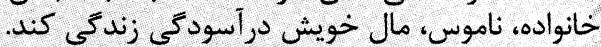

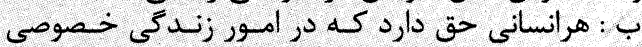

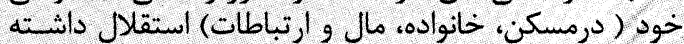

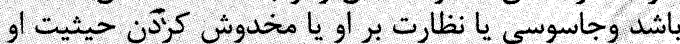

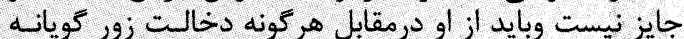

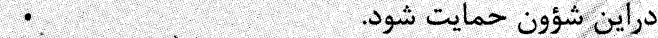

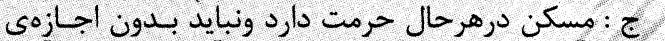

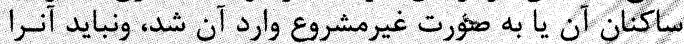

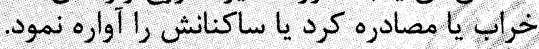

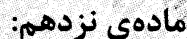

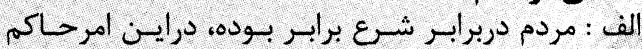
ومحكوم نيز باهم برابر ند. ب : مراجعه ويناه بردن به دادكاه حقى است كـه به بـراى

همه تضمين شده است. ج: مسؤوليت دراصل شخصى است. د : هيج جرمى يا مجازاتى نيست مكر به موجب احكـام

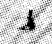
شُريعت : من ه : متهم، بع كناه است تـا ايـن كـه محكـوميتش از راه

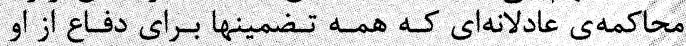
فراهم باشد ثابت كردد. مادهى بيسته : مابت كردي

دستكيرى يا محدود ساختن آزادى يا تبعيد يا مجازات

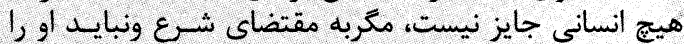

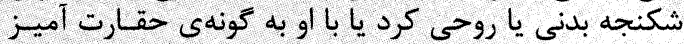

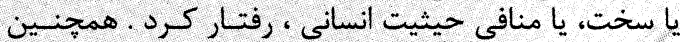

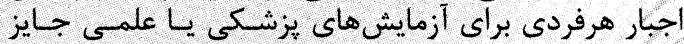

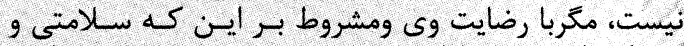

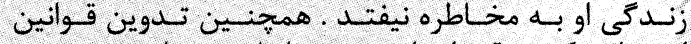

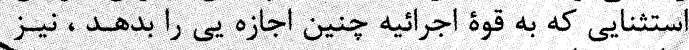

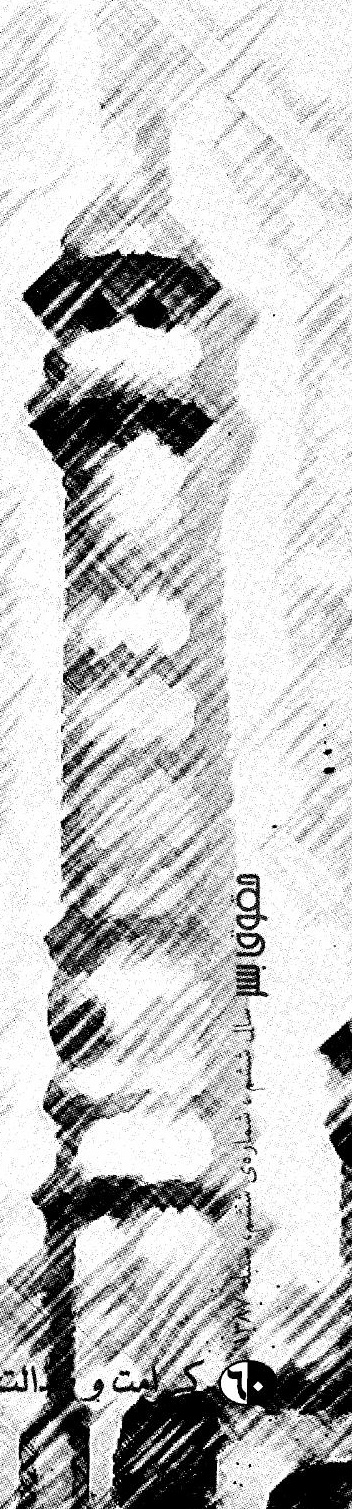




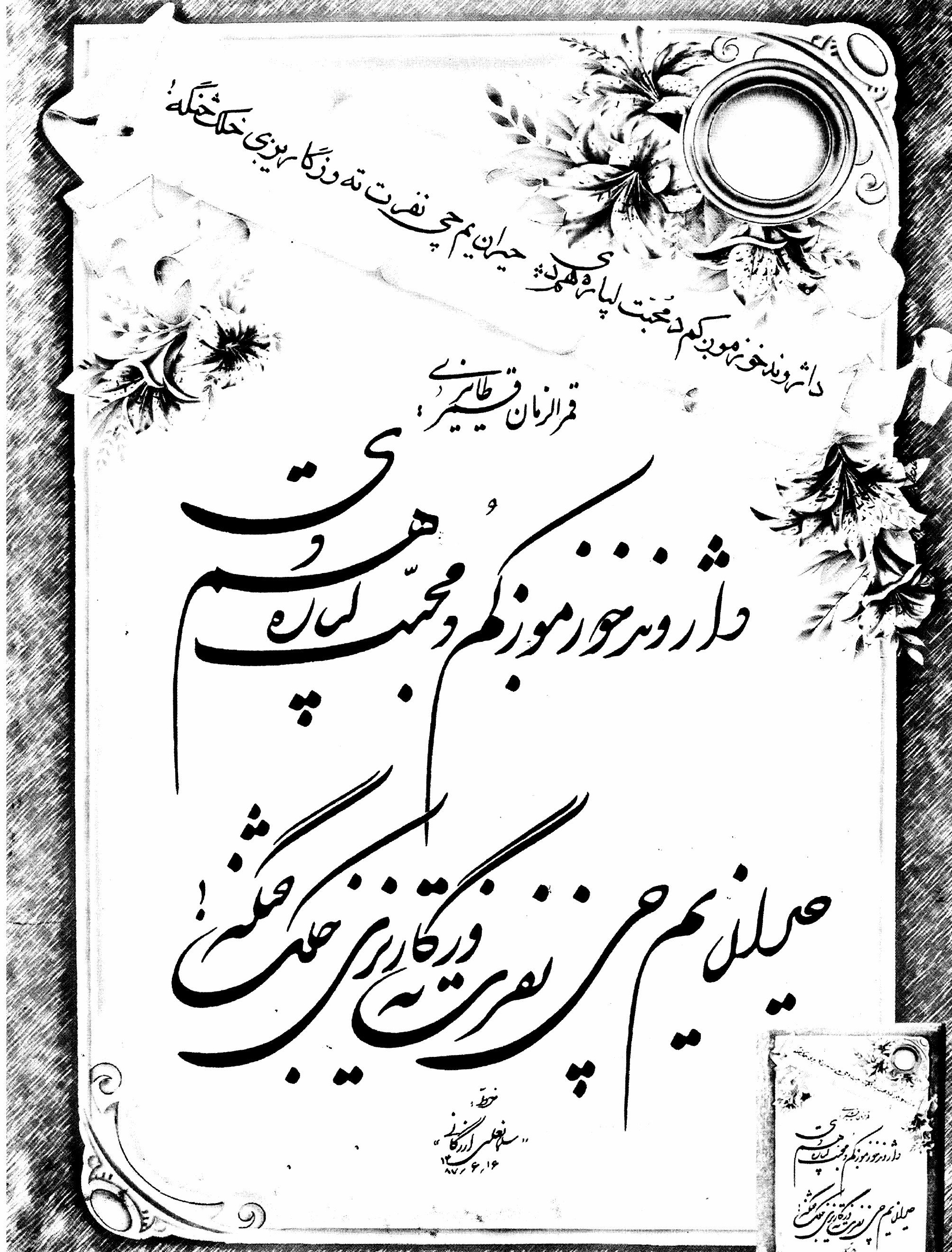




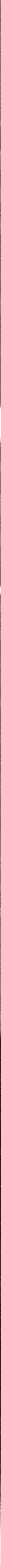

